\title{
MEDIEVAL ARABIC HISTORIOGRAPHY
}

Medieval Arabic Historiography is concerned with social contexts and narrative structures of pre-modern Islamic historiography written in Arabic in thirteenth-century Syria and Egypt. Taking up recent theoretical reflections on historical writing in the European Middle Ages, the study combines approaches drawn from social sciences and literary studies and focuses on two well-known texts by Abū Shāma (d. 1268), The Book of the Two Gardens, and Ibn Wāṣil (d. 1298), The Dissipater of Anxieties. Both texts describe events during the life of the sultans Nūr al-Dīn (d. 1174) and Salāh al-Dīn (d. 1193), who are primarily known as the champions of the anti-Crusade movement. This book shows that the two authors were active interpreters of their societies and had considerable room for manoeuvre in both their social environment and the shaping of their texts.

Through the use of a new theoretical approach to pre-modern Arabic historiography, this book presents an original reading of the texts. Medieval Arabic Historiography provides a significant contribution to the burgeoning field of historiographical studies and is essential reading for those with interests in Middle Eastern Studies and Islamic and Arabic History.

Konrad Hirschler gained his PhD from the School of Oriental and African Studies, London. He is Lecturer in Islamic Studies at the University of Kiel, Germany. His main research interests include modern and medieval historiography, as well as social and cultural history. 


\title{
SOAS/ROUTLEDGE STUDIES ON THE MIDDLE EAST Series Editors
}

\author{
Benjamin C. Fortna, SOAS, University of London \\ Ulrike Freitag, Freie Universität Berlin, Germany
}

This series features the latest disciplinary approaches to Middle Eastern Studies. It covers the Social Sciences and the Humanities in both the pre-modern and modern periods of the region. While primarily interested in publishing single-authored studies, the series is also open to edited volumes on innovative topics, as well as textbooks and reference works.

1 ISLAMIC NATIONHOOD AND COLONIAL INDONESIA

The Umma below the winds

Michael Francis Laffan

2 RUSSIAN-MUSLIM CONFRONTATION IN THE CAUCASUS

Alternative visions of the conflict between Imam Shamil and the Russians, 1830-1859

Thomas Sanders, Ernest Tucker and G.M. Hamburg

3 LATE OTTOMAN SOCIETY

The intellectual legacy

Edited by Elisabeth Özdalga

4 IRAQI ARAB NATIONALISM

Authoritarian, Totalitarian and pro-Fascist inclinations, 1932-1941

Peter Wien

5 MEDIEVAL ARABIC HISTORIOGRAPHY

Authors as actors

Konrad Hirschler 


\section{MEDIEVAL ARABIC HISTORIOGR APHY}

Authors as actors

Konrad Hirschler

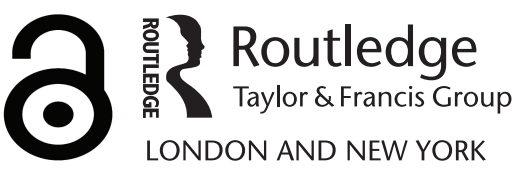


First published 2006 by Routledge

Published 2017 by Routledge

2 Park Square, Milton Park, Abingdon, Oxon OX14 4RN

711 Third Avenue, New York, NY 10017, USA

Routledge is an imprint of the Taylor E Francis Group, an informa business

Copyright () 2006 Konrad Hirschler

Typeset in Garamond by

Newgen Imaging Systems (P) Ltd, Chennai, India

The Open Access version of this book, available at www.tandfebooks.com, has been made a vailable under a Creative Commons Attribution

-Non Commercial-No Derivatives 4.0 license.

British Library Cataloguing in Publication Data

A catalogue record for this book is available from the British Library

Library of Congress Cataloging in Publication Data

A catalog record for this book has been requested

ISBN13: 978-0-415-38377-6 (hbk) 


\section{CONTENTS}

List of illustrations vi vi

Acknowledgements vii

Notes on romanization and terminology viii

1 Introduction 1

2 Historical and historiographical background 7

3 Social contexts $\quad 15$

4 Intellectual contexts 43

5 Textual agency I: titles, final sections and historicization 63

6 Textual agency II: micro-arrangement, motifs and political thought 86

$\begin{array}{lll}7 & \text { Reception after the seventh/thirteenth century } & 115\end{array}$

8 Conclusion 122

Appendix 124

$\begin{array}{ll}\text { Notes } & 127\end{array}$

Bibliography 159

$\begin{array}{ll}\text { Index } & 173\end{array}$ 


\section{ILLUSTRATIONS}

\section{Figures}

1 Network Ibn Wāṣil

2 Ibn Wāṣil in Egypt (643-early 660s)

\section{Tables}

1 Arrangement 'Campaign to Mosul' 


\section{ACKNOWLEDGEMENTS}

This study developed out of a $\mathrm{PhD}$ thesis on Arabic historical writing submitted to the School of Oriental and African Studies. I would like to express my gratitude in the first place to Ulrike Freitag. My discussions with her were a constant source of inspiration and her support, even in rather extraordinary circumstances, was crucial in many regards. I am indebted to Gerald Hawting for following this project through to completion with much care. Peter Holt and Carole Hillenbrand helped me to sharpen the argument with their detailed and thorough critique.

I wish also to thank those people who were kind enough to read parts or all of the manuscript and to make encouraging and helpful comments: Benjamin Fortna, Stefan Conermann, Edwin Towill, Achim Rohde, Joachim Hirschler and Albrecht Hirschler. Furthermore, I wish to thank Stefan Sperl, Guido Steinberg and Stefan Heidemann, who provided me with copies of unpublished work or helped with other information. Michael Brett supported me in a variety of ways and the conversations with him were always especially enlightening.

As I complete this study, I am prompted to express gratitude for guidance received at different stages from two people to whom I owe in very large measure my interest in historiography: Richard Rathbone and the late Albrecht Noth.

Drafts of some chapters were presented at the Tenth Colloquium on the History of Egypt and Syria in the Fatimid, Ayyubid and Mamluk Eras, Leuven, 9-11 May 2001, the XXVIII Deutscher Orientalistentag, Bamberg, 26-30 March 2001, the Eleventh Colloquium on the History of Egypt and Syria in the Fatimid, Ayyubid and Mamluk Eras, Leuven, 16/17 May 2002 and the First World Congress for Middle Eastern Studies, Mainz, 8-13 September 2002. Those present helped me with their insightful comments and their questions to rethink aspects of the argumentation. I am indebted to the SOAS History Department and the Evangelisches Studienwerk Villigst - Germany for their financial support.

And finally, I wish to thank especially my parents, my brothers, my wife and my children who have supported me in a variety of ways during the last years. 


\title{
NOTES ON ROMANIZATION AND TERMINOLOGY
}

\begin{abstract}
Romanization
Terms commonly used in English, such as amir, caliph, fatwa, imam, Quran, Shiite, sultan, Sunni, Sufism and vizier are reproduced without diacritics and are not formatted in italics. Similarly, proper nouns are never formatted in italics. For those referring to well-known places/regions and dynasties diacritics are omitted, except the letter 'ayn in the beginning, that is Damascus, Cairo, and Syria; 'Abbasids, Fatimids, Zangids, Saljuqs, Ayyubids and Mamluks. Other proper nouns are romanized with full diacritics: al-Jazīra, Harrān. All other terms from foreign languages are formatted in italics and, if applicable, fully romanized according to the ALA-LC Romanization Tables for Arabic (Transliteration Schemes for Non-Roman Scripts, approved by the American Library Association and the Library of Congress) with two changes. First, the final inflection of verbs, pronouns, pronominal suffixes and demonstratives is also retained in pause, for example, bayātubu wa-'așrubu instead of hayātubu wa-'așuh. Second, the 'h' for $t \bar{a}$ ' marbüta at the end of nouns and adjectives, which are either indefinite or preceded by the definite article, is omitted, for example, madrasa and al-risāla instead of madrasah and al-risālah. ${ }^{1}$ In order to facilitate the text for readers who are not acquainted with Arabic, terms in plural are generally given in the singular form with an English plural, that is, 'älim/'älims not

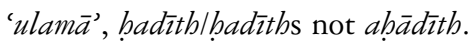

\section{References}

Primary and secondary sources are referred to in the footnotes with dissimilar systems in order to facilitate a clear differentiation. Primary sources are cited with 'author, title, page', for example, Abū Shāma, Dhayl, 50. Secondary sources are cited with 'author (year), page', for example, Watt (1968), 86-7. Volume numbers are given in Roman numbers, for example Hodgson (1974), I, 233-40 and al-Ṣafadī, Wāfī, XVIII, 113-16. Footnotes referring to individuals do not provide all the available primary sources, but only those relevant for the argumentation. Readers looking for a more comprehensive list of the available sources should consult al-Dhahabī's Tárikh al-islām, which is indicated whenever a reference exists. 


\section{Periodization}

The terms 'Middle Ages' and 'medieval', which are the terms most currently employed for the period dealt with in this study, are obviously neither neutral in a geographical nor in a chronological sense. For the European context they generally exclude certain regions, such as the Baltic and the Slavic parts, implying distinctively what is perceived to be the centre of Europe. Furthermore, the terms imply clear periods of break, which are mainly linked to the function of the Middle Ages as the scorned or romanticized Other of modernity. Nevertheless, the terms remain widely used, which is probably due to a further - sometimes quite helpful - characteristic: the fuzziness of their exact delimitation in space and time. ${ }^{2}$ The terms become even more problematic for the region called presently 'Middle East'. Although the terms are widely used, one finds only rarely reflections on what period of Arab history can be seen as 'medieval' and what the characteristics of such a 'Middle Age' would be. ${ }^{3}$

The traditional periodization according to ruling dynasties is not very helpful, although it reflects to a large degree the schemes chosen by medieval Arab historians themselves. It is highly questionable to what degree changes of dynasties marked far-reaching shifts in the society as a whole. ${ }^{4}$ The widening of the field of history to issues beyond the traditional 'grand politics' during the last century renders such a narrowly defined periodization inapplicable for the variety of topics covered.

Hodgson has proposed an alternative to the dynasty-based periodization by distinguishing the High Caliphate (until 334/945) from the following Middle Periods. ${ }^{5}$ While this terminology is not focused too strictly on dynastic changes, it is still mainly based on political developments. Furthermore, the perception of the cultural sphere, the second factor Hodgson refers to in his discussion besides politics, follows closely the approach of Rise (development of Islam during the first/seventh century), Golden Age (height of the Umayyad and 'Abbasid caliphates until the fourth/tenth and fifth/eleventh centuries) and Decline (periods thereafter). As it stands, his proposition introduces merely the equivalent for the differentiation between Early, High and Late Middle Ages current for the European context.

The employment of the relative neutral centuries, be it according to the Islamic or the Julian/Gregorian calendars, is free of the burdened connotations of the other periodizations. However, their coherent application merely avoids the problem without proposing any substantial alternative. While the use of terms such as 'medieval' obliges the author at least to reflect upon his or her understanding of periodization, the employment of 'neutral' centuries might lead to a periodization devoid of any analytical value.

The only convincing solution for the moment seems to be a combination of the different possibilities. Despite the problems mentioned here I will often define the period I refer to in this study by chronological terms, for example, 'Arabic historical writing in the seventh/thirteenth century'. This choice is a result of my study being mainly a microstudy of two authors and their texts in a circumscribed period. This means that the study's results have to be understood within its well-defined temporal framework. Consequently, terms implying a too high degree of generality have to be avoided. 
Whenever the terms 'Medieval'/'Middle Ages' are used in this study, they refer to the period from the late fifth/eleventh to the early tenth/sixteenth centuries. Al-Azmeh (1998) shows that for this period the use of these terms with the connotations of transition has certain legitimacy, as the beginnings of Islam were a continuation of developments of late Antiquity. It was only in the later 'medieval' periods that most of the characteristic traits of Islamic societies emerged. Hence, it is in the aftermath of the 'interregnum' of the Turkic invasions in the fifth/eleventh century and after, that 'medieval' becomes a meaningful term for the Arab lands, without having the underlying connotations of Decline in the aftermath of what has been described the Classical or Golden Age.

The early tenth/sixteenth century can be seen as a period of fundamental change due to the increasing dominance of the Ottoman Empire throughout the regions of the Middle East. For the first time since the regionalization of power in the late fourth/tenth century nearly all regions were, politically, orientated towards a single centre, Istanbul. The Ottomans filled, similar to the Safavids and Mughals, the political vacuum left by the two Mongol incursions and the following disintegration of their empires. The rise of the Ottomans was not only relevant on the political level, but also with regard to the use of language. The increased importance of Ottoman Turkish replaced to a certain degree the predominant Arabic, with Ottoman Turkish starting to play a salient role in the Muslim west. Arabic historical writing must therefore be studied after this period in close connection with Ottoman Turkish historical writing and can hardly be considered independently.

The periods before the Middle Ages, as defined here, will be called 'formative'. Contrary to Hodgson's term 'High Caliphate', 'formative' period seems to me less connected to the idea of a Golden Age with an implied following Decline. Azmeh's proposal to term this period 'late-Antiquity' seems a valuable proposition, but would demand further research before being employed. The main advantage of the term 'formative' is the stress on the ongoing processes in developing distinctive traits in fields such as administration and jurisprudence. 


\section{INTRODUCTION}

This study reflects on the room for manoeuvre - or the agency - that medieval authors of Arabic historical narratives disposed of in composing their texts. It will therefore ask what the authors' degree of agency was in composing the works in terms of the social context in which they acted, the learned tradition in which they stood, and the textual environment in which they composed their works. Agency here means:

the capacity of socially embedded actors to appropriate, reproduce, and, potentially, to innovate upon received cultural categories and conditions of action in accordance with their personal and collective ideals, interests, and commitments.

(Emirbayer/Goodwin (1994), 1442-3)

Reflecting on the room for manoeuvre in these different fields requires a detailed analysis of the authors' social and intellectual contexts and their narratives. As the approach chosen here for studying medieval Arabic historical writing precludes a broad survey of a large number of authors and their texts, I offer a comparative case study by considering two specific examples in depth: Abū Shāma (d. 665/1268) and his Kitāb al-rawdatayn fī akbbār al-dawlatayn al-Nürīya wa-al-Salābīya (The Book of the Two Gardens on the Reports of the Two Reigns [of Nūr al-Dīn and Șalāh al-Dīn]) as well as Ibn Wāṣil (d. 697/1298) and his Mufarrij al-kurūb fì akbbār bañ̄ Ayyūb (The Dissipater of Anxieties on the Reports of the Ayyubids). ${ }^{1}$

Although the narratives chosen here are important to the sixth/twelfth and seventh/thirteenth centuries, they are rather minor texts compared with the 'grand' authors generally discussed in surveys of Arabic or Islamic historical writing. Two considerations informed the decision to focus on these two authors and their texts. First, Ibn Wāṣil and Abū Shāma are particularly suitable for comparison, as they both lived in the same period and in the same region. And as their texts also partly deal with the same events, it is possible to analyse how these two Shāfi'ite 'älims developed, in their outwardly quite similar texts, distinctive versions of their immediate past. In this sense, they are ideal examples of the diversity and complexity of premodern Arabic historical writing. Second, although a study of grand historians and 
their texts, such as al-Tabarîs (d. 310/923) Ta'rīkh al-rusul wa-al-mulūk or Ibn Khaldūn's (d. 808/1406) Kitāb al-ibar, might have reinforced the notion of these authors' exceptionality, it is one of the central contentions of this study that even texts of 'minor' authors appear as more multi-faceted than previously assumed.

The rationale for proposing yet another study of pre-modern Arabic historical writing is that narrative texts still provide the main sources for studying this period: despite increasing diversity in the sources consulted (e.g. architecture and numismatics), ${ }^{2}$ the relative scarcity of documentary material ${ }^{3}$ leaves the present-day historian with little choice but to consult narrative texts. In contrast to long periods of European medieval history, these texts are often the only way a given age can be accessed. ${ }^{4}$ Because narrative texts are so significant to our understanding of the past, it is essential to reflect on how they were produced and what different layers of meaning they contain.

The choice of the specific issue treated here - agency - is chiefly a reaction to previous evaluations of medieval Arabic historical writing. In addition to the texts of many other medieval historians, Abū Shāma's and Ibn Wāșil's narratives have been seen as being largely determined by 'external' factors: the circumscribed social environment (e.g. Ibn Wạșil's dependency on his royal patron), the stagnating intellectual context of the 'post-classical' age (in Abū Shāma's case his immersion in the 'barren' field of religious sciences), and the authors' close reliance on previous historical narratives, which they supposedly merely reproduced in more or less elaborate ways.

This perspective on authors of medieval Arabic narratives is closely connected to the Rise - Golden Age - Decline paradigm, ${ }^{5}$ which to some extent influenced twentieth-century scholarship of Arabic historical writing, for instance Rosenthal's (1968) monumental A History of Muslim Historiography. In his view, all crucial developments had their source in the early 'ideal' periods of Islam, that is the texts 'written in the second half of the first century [. . . contained already all the formal elements of later Muslim historiography'. ${ }^{6}$ Due to this assumption that each later phenomenon can be explained by the genre's inherent origins or genealogy, he traces the texts back to their origins in the Rise and Golden Age of the civilization and considers them to be quasi-independent of later developments within society. ${ }^{7}$ History writing is conceptualized here in terms of encapsulated civilizations with underlying schemes of comprehensive 'genetic' interconnections. The early Islamic origins of this genre, not its respective contexts, were the determinants for most of its later developments. Rosenthal's notion of time is not one of change, but rather one of endless repetition. ${ }^{8}$ Within this analytical framework, the only possible major development is the genre's decay parallel to the general decline of the civilization. ${ }^{9}$

Nevertheless, during the past decade there have been two important trends in the study of Arabic historical writing, which are best represented by the studies of Khalidi (1994) and el-Hibri (1999). Khalidi considers Arabic historical writing from the point of view of the social historian by taking into account the respective social and political developments, which influenced the production of historical texts. Despite some shortcomings, such as the absence of a discussion of what he 
understands by the crucial term 'historical thought', ${ }^{10}$ his inquiry represents a substantial re-orientation towards taking social contexts into account, and focusing less on the issue of 'origins'. ${ }^{11}$

El-Hibri's (1999) work on 'Abbasid historical writing reflects the second trend, namely the increasing influence of literary approaches in the field of history. His main argument is that the "historical accounts of the early 'Abbāsid caliphs were originally intended to be read not for facts, but for their allusive power'. ${ }^{12}$ Although he refrains from formulating a specific framework, his study is, for the moment, the most comprehensive and far-reaching examination of pre-modern Arabic historiography, which includes ideas from the field of literary studies. ${ }^{13}$

In this way Khalidi and el-Hibri have advanced the field by applying a specific set of approaches, respectively drawn from social studies and literary studies. However, both studies stand rather isolated from one another and largely exclude other concerns. Thus Khalidi is barely concerned with the texts themselves, while the social context of the texts rarely appears in el-Hibri's work.

It is in the study of European medieval historical writing that Spiegel has proposed a fruitful combination of the concerns of social history and literary studies. ${ }^{14}$ In her study on thirteenth-century vernacular prose historical writing in France she stresses that the meaning of those texts can only be grasped in relation to their social context, in this case, essentially, the development of the societal position of the aristocratic patrons. ${ }^{15}$ At the same time, she strives to deal with the complex relationship between text and context, since in her approach texts both reflect and produce social reality. She applies elements of literary analysis, for example when the transformation of vernacular historical writing from poetry to prose is not seen as a move towards accuracy, but as a discursive means in order to 'appropriate [. . . the inherent authority of Latin texts'. ${ }^{16}$ Spiegel has striven to conceptualize her approach on a more general level by aiming at a Theory of the Middle Ground. ${ }^{17}$ In this discussion she deals mainly with the paradox of simultaneously applying literary approaches based on the assumption of the non-referentiality of texts and approaches of social history based on the referentiality of texts. ${ }^{18}$

\section{The approach of this study}

The present study aims to use this combination of approaches to the field of Arabic medieval historical writing to bridge the gap between recent trends in the field as represented by Khalidi and el-Hibri. It assumes that medieval Arabic historians were active interpreters of their society, and that these authors sought to make sense out of the past, which they presented in (relatively) coherent narratives by employing the right to speak. In this regard the central question will therefore be how they produced meaningful narratives within their societal context. But before turning to the sources, the three axes of inquiry set out in the question - 'meaning', 'narrative' and 'societal context' - need to be conceptualized.

In recent decades 'meaning' has become an increasingly important concern in historical studies. ${ }^{19}$ Geertz is one of the influential writers who consider culture to be 
a system of symbols and meanings. Texts (in a very comprehensive sense) are mainly interesting as a part of this system: they have not so much to be explained as interpreted in order to grasp both their symbolic content and meaning, ${ }^{20}$ and are not seen as merely the direct outcome of material reality or of social processes. ${ }^{21}$ However, under the influence of structuralism, Geertz considers culture in sharp contrast to a societal system (norms and institutions) or a personality system (motivations). In that way he endows culture with rather static and coherent characteristics and with a very high degree of autonomy vis-à-vis these other systems.

In reaction to this, the approach to culture has been further developed by considering it as a sphere of practical activity, where wilful action, power relations, contradiction and change play a significant part. ${ }^{22}$ Sewell, amongst others, proposes culture as an indissoluble duality of system and practice: in order to act, a system of symbols is required, but this system of symbols exists merely through practice. ${ }^{23}$ Human practice has been structured by elements by meaning, but also by power relations or resource distribution. Although these fields have a certain degree of autonomy vis-àvis one another, they also shape and constrain each other. Thus, in discussing the texts under consideration in this study I will ask how they produced meaning by considering other relevant spheres. The linked assumption is that the criterion for inclusion of information was not necessarily their truth-value but possibly their significance within a specific context.

With regard to narrativity, the basic concern comes down to the question of how medieval authors fashioned originally isolated and disparate facts and events into a literary narrative. One of the starting points for the analysis of the narratives in Chapters 5 and 6 will be the concept of 'modes of emplotment'. Here, I will draw on the writings of Hayden White in order to propose an alternative reading of seventh-/thirteenth-century historical writing.

White's main argument is that historical writing is as fictional as other forms of literary expression, being 'a verbal structure in the form of a narrative prose discourse'. ${ }^{24}$ Individual events, persons and institutions are formed into a coherent story based on a tropological strategy: the narrative is prefigured by the author's decision to use one of the four main tropes (Metaphor, Metonymy, Synecdoche and Irony). Although White's concept of historical writing has been widely criticized, ${ }^{25}$ his crucial point has proved to be influential: the consideration of historical writings less as unproblematic and directly mediated reality, and more as literary narratives endowing events with meaning. Kellner formulates this as 'the tendency of late 20th century thought to look at rather than through a telescope', the telescope being language. ${ }^{26}$

However, the principal aim in this study is not to apply a given concept to the field under consideration deductively: rather, the analysis is supplemented by criteria developed inductively from the historical narratives. In this regard, authors such as Frye and Auerbach ${ }^{27}$ offer a broad framework for the inquiry. The main question is how the authors ascribed different meanings to their immediate past, although they largely drew on a common textual basis. Here, three themes will reappear frequently in the course of the textual analysis of Ibn Wāṣil's and Abū Shāma's narratives: exclusion/inclusion, arrangement and different literary elements. 
The theme of exclusion/inclusion is an important one, as Abū Shāma produced hardly any 'original' material in his text and Ibn Wāșil only as the narrative reaches the author's maturity. Contrary to studies focusing on factual concerns, in the following discussion these citations are not considered to be irrelevant if a more 'original' text exists. Rather, these citations might gain a different meaning in different textual context or by very slight changes. Medieval Arabic texts seem at first glance to be chaotically arranged and to contain a number of different elements: narrative sections, disconnected anecdotes, direct quotations, poetry, letters, etc. However, it might be better to understand these texts (as has been recently suggested for the genre of pre-modern autobiographies) 'not [as] a chaotic jumble devoid of personalities, but [as] a discourse of multiple texts' ${ }^{28}$

Despite its non-originality, Abū Shāma's work gained considerable popularity from its 'publication' in the seventh/thirteenth century onwards. ${ }^{29}$ This development arguably demonstrates that it was not only the material included, which decided a work's popularity but also the specific outlook, with which the author framed his narrative. Beyond doubt, historical writing in the pre-printing era also served to preserve existing information or to display literary refinement. However, a comparative analysis between the Mufarrij and the Rawdatayn will show to what degree quite similar texts drawing on the same textual basis might acquire different meanings.

Inclusion is thus understood here as the author's conscious choice to shape his text. By taking one or more texts as models on which to base his narrative, a specific vision of the past emerges. Passages from the model texts can be reproduced verbatim, changed slightly and/or set into a different textual context. ${ }^{30}$ For example, while Abū Shāma tended to cite reports verbatim, Ibn Wāṣil mostly integrated the different sources into an 'original' narrative. I will generally cite the two works without necessarily indicating whether it is an 'original' or 'copied' passage.

However, the assumption of authorial control over the texts should not be taken too far. While the authors were, in my opinion, able to shape the narratives to a greater degree than previously assumed, this control clearly had its limits. For example, on the one hand Abū Shāma was able to provide his text with a clear profile with regard to arrangement by including citations from previous texts. However, on the other hand by doing it that way he lost some control over such literary elements as 'motifs', since the inclusion of fragments derived from a variety of texts precluded here the development of a distinctive profile.

The second main theme is the question of arrangement. Even where Abū Shāma and Ibn Wāșil both used the same material, the question remains as to how it is positioned in their respective texts, and how the texts are internally structured. In my textual analysis I refer to the two possibilities as 'macro-arrangement' and 'microarrangement'. 'Macro-arrangement' is to do with why specific reports, included in both texts, are differently placed within the narratives. A prominent example of this is Nūr al-Dīn's biography: although it appeared in both texts, its different positions (in Ibn Wāṣil's text at the usual place, after his death; in Abū Shāma's text as the opening scene of the whole narrative) give it quite distinct meanings (as discussed in Chapter 5). Micro-arrangement, on the other hand, is concerned with reports 
included in both texts in the same position. It deals with the internal arrangement of these reports, that is how did the authors arrange their material about a specific event to form a report. These differences between Abū Shāma's and Ibn Wāsil's narratives will be described in Chapter 6, with the opposed terms 'circular' and 'linear'.

The last theme, literary elements, refers to the integration of different means in order to narrate a specific report. The textual strategies included such elements as direct speech with shifts between first and third person, oaths, poetry, letters, quotations from sacred texts and overt authorial intervention.

Meaning and narrativity cannot be considered in isolation from other spheres existing in a given society. Contextualization is meant here in a broad sense, including both the social and the intellectual environment in which the authors acted. The first step (Chapter 3) will be a social contextualization in the established sense of the term. Here, the concept of networks allows reading texts of authors close to court circles as more than mere reflections of the patron's outlook. The application of the concept of networks to the social context is similar to the understanding of culture as outlined earlier: both are characterized less by rigid institutions and structures than by processes and relations. The second step will be an intellectual contextualization in the sense of the history of ideas. Issues such as the authors' educational background (e.g. fields of learning) and their works in the different fields will be considered (see Chapter 4). 


\title{
HISTORICAL AND HISTORIOGRAPHICAL BACKGROUND
}

\begin{abstract}
Abū Shāma and Ibn Wāșil wrote their chronicles in Syria ${ }^{1}$ in the seventh/thirteenth century and arranged them annalistically, in the then prevailing style of history writing. They dealt mainly with the history of the Syrian and Egyptian lands, starting with the beginning of Nūr al-Dīn's (d. 569/1174) dynasty, the Zangids, in the late fifth/eleventh century. Abū Shāma's Rawdatayn ended with Șalāh al-Dīn's death in 589/1193 and its following few pages dealt only briefly with subsequent events. Ibn Wāșil's chronicle, in contrast, extended well into the author's lifetime and broke off (depending on the manuscript examined), either during the year 659/1261 or at the end of $661 / 1263 .^{2}$

The textual analysis in this study will focus on passages dealing with the period covered by both authors: the reigns of Nūr al-Dīn and Șalāh al-Dīn. In both texts it was the political history of the period which was central - that is to say, first the dynastic transitions from the Fatimids (in Egypt) and the Zangids (in Syria and al-Jazīra ${ }^{3}$ ) to the Ayyubids and second, conflicts involving the Crusaders. However, the role of the Crusaders should not be overstated, since, unlike the dynastic issue, it did not achieve such a central importance in the texts. This was also indicated by the 'factual' parts of the titles: On the Reports of the Two Reigns [of Nūr al-Dīn and Salāh al-Din]) and On the Reports of the Ayyubids. Further subjects, such as events linked to the scholarly community of the 'alims, received only a relatively marginal place in the authors' narratives. As the texts were mainly concerned with the dynastic issue, the following section provides a brief outline of the main events of the period.
\end{abstract}

\section{Historical background}

The Ayyubids (r. 564/1169-650/1252 in Egypt, 570/1175-658/1260 in Syria) ruled their lands as a family confederation, especially after the death of Salāh al-Dīn. Members of the dynasty held the different towns, often in conflicting relationships. Shifting alliances and coalitions among the dynasty's rulers, which also involved outside actors, led to myriad conflicts. The particular ruler of Egypt generally claimed the overlordship, but had continuously to assert and ultimately defend his position against the opposed interests of his relatives. The careers of al-Malik al-'Ādil (r. 596/1200-615/1218), al-Malik al-Kāmil (615/1218-635/1238) and al-Malik 
al-Ṣālih (637/1240-647/1249), the main Ayyubid rulers of Egypt, were largely consumed with efforts to foster and/or expand their positions, but however successful they were, their death set back their efforts, and each successor had to start imposing the centre's hegemony anew.

It was the Ayyubid branches in places such as Aleppo, Homs, Hama, Damascus, Karak, Baalbek, Diyār Bakr and Bāniyās which refused the claims by a single family member to overlordship. Although they voluntarily accepted the incumbent ruler of Egypt as part of their alliances, there was minimum consensus among them about preventing his dominance. Short-lived all-Ayyubid alliances only emerged when an outside power threatened the survival of the entire confederation, such as, for example, the 615/1218 Crusade against Egypt.

This structure of the Ayyubid reign was also a legacy of the Saljuqs' previous rise to power in most of the Islamic Asian world in the fifth/eleventh century. The Saljuqs, originally nomadic tribesmen from Central Asia, had conquered the former 'Abbasid lands and finally seized Baghdad in 447/1055. They adhered to the concept of a family empire divided among brothers and cousins, in contrast to the 'Abbasid ideal of unitary rule. ${ }^{4}$ Within this, the sultan was the nominal overlord while the empire was de facto divided among the members of the ruling house. The everpresent centrifugal tendency in such a system was checked as long as the sultan disposed of sufficient power resources vis-à-vis the periphery. However, the decisive weakening of central Saljuq rule in Baghdad in the late fifth/eleventh century replaced the empire's unity in the following decades with a number of regional dynasties in the various regions stretching from Anatolia to Khurāsān.

In al-Jazīra and Syria, it was the Zangid dynasty that established its hegemony during the first half of the sixth/twelfth century. Nūr al-Dīn's father, 'Imād al-Dīn Zankī (d. 541/1146), was appointed after a distinguished career as governor for the Saljuq sultan of the lands between Mosul and Aleppo. Acting at the same time as atābak to two of the sultan's sons, he increasingly consolidated independent rule in his lands. Restrained by Saljuq dominance to his east he expanded his realms further into Anatolia and Syria. With the establishment of his dominance over Damascus and the conquest of Edessa (the first major Crusader stronghold in the Islamic lands), he bequeathed the region's major power to his sons.

Indeed, in the tradition of the former Saljuq overlords, the lands were divided among sons. The eastern lands, with Mosul at its centre, passed into the hands of the eldest son Sayf al-Dīn (d. 544/1149), while Nūr al-Dīn, the second son, established himself in the Syrian lands. Nūr al-Dīn united those lands, which were not ruled by the Crusaders, from northern Syria to the south of Damascus. And while he never achieved a spectacular conquest - such as his father's at Edessa - he was engaged in regular warfare with the Crusaders. Having remained the only considerable force in the region after Nūr al-Dīn had incorporated most of the Muslim regions into his realm, the Crusader states were his natural opponents. At the same time, the Byzantine Empire and the Rūm ${ }^{6}$ Saljuqs from the north remained by turns important allies and opponents. The decisive change occurred during the later part of Nūr al-Dīn's rule as Egypt came increasingly to his attention. 
As a result of the Fatimid Empire's decreasing stability, the factions in Cairo started to have recourse to outside support; most importantly, the Crusaders and Nūr al-Dīn (the latter from 559/1164 onwards) began to assert a position in the quickly developing Fatimid political landscape. Nūr al-Dīn's third direct involvement proved finally successful, and in 564/1169 his commander Shīrkūh gained a foothold in Egypt. After Shīrkūh's immediately following death, it was his nephew Șalāh al-Dīn who was appointed as Fatimid vizier. Șalāh al-Dīn ended his uncomfortable position - owing loyalty to the Fatimid imam as his vizier and being at the same time Nūr al-Dīn's man in Egypt - in 567/1171 when he officially abolished the Fatimid reign after they had ruled Egypt for some two centuries.

However, Șalāh al-Dīn did not stop here, but also entertained an ambiguous stance towards Nūr al-Dīn, his titular overlord. Although he never challenged him overtly, his supposed allegiance was rarely translated into active support. After the death of Nūr al-Dīn in 569/1174, Șalāh al-Dīn profited from Zangid 'disunity' (or rather, the normal contests for supremacy within the family) and in the following decade imposed his supremacy in Syria (and beyond), culminating in the seizure of Aleppo in 579/1183. The Ayyubid dynasty brought to power by Ṣalāh al-Dīn was to retain a hegemonic position in Egypt and Syria until the mid-seventh/thirteenth century. Șalăh al-Dīn consolidated his rule further in the east (gaining nominal overlordship over Mosul) and increasingly fought the Crusaders - again the last remaining considerable forces in the region. Nevertheless, it was only towards the end of his life that he decisively defeated them at the legendary battle of the Horns of Hațtin in $583 / 1187$.

After Ṣalāh al-Dīn's death in 589/1193 the reign passed to his brother al-Malik al-'Ādil who succeeded in asserting his supremacy against Șalāh al-Dīn's sons; he was finally proclaimed sultan of Egypt and Syria seven years after his brother's death. Distributing the lands among his own sons, he himself moved from place to place without ruling a province directly. His eldest son, al-Malik al-Kāmil, succeeded him in the sultanate of Egypt, but achieved supremacy in Damascus only shortly before his death in 635/1238 - he was unable to impose a stable hegemony on the major Syrian towns against the resistance offered by his brothers. Al-Kāmil's eldest son al-Malik al-Șālih started from an unfavourable position, having been relegated by his father to al-Jazira. Again, he spent most of his career fostering his position by taking Egypt (637/1240) and Damascus (644/1247), but before being able to profit from his enhanced resources by expanding further in Syria, he died in 647/1249, defending Egypt against the Crusade by Louis IX.

The Ayyubid rule subsequently dwindled away. The brief rule of al-Ṣālih's son Tūrānshāh (d. 648/1250) ended with the young ruler's assassination within a year of his accession. The regicides were the Mamluks who proved to be the new masters of Egypt and, within a decade, of Syria also. The sultanate was still technically held by al-Ṣāliḥ's widow Shajar al-Durr (d. 655/1257), and subsequently by a minor Ayyubid prince. However, the proclamation of 'Izz al-Dīn Aybak as sultan in 652/1254 ended even the nominal Ayyubid rule in Egypt. The defeat of the Mongols in Syria in 658/1260 by the Mamluks also initiated the end of Ayyubid rule in the major Syrian 
towns. With the exception of the Ayyubids in Diyār Bakr, it was only in Homs for another decade, and in Hama until the eighth/fourteenth century that Ayyubid rulers continued under Mamluk sovereignty.

With the arrival of the Mamluks, the Saljuq model of decentralized rule came to an end. Although periphery-centre conflicts continued, governors in the Syrian towns were not able to challenge the sultan in Egypt as they had done previously. Under the Saljuqs and their successors the lands had been entrusted to the sultan's male family members, but the Mamluk system of rule precluded this possibility: the dynastic principle was weakened (apart from the sultan Qalāwūn (d. 689/1290) no Mamluk ruler was able to establish a lasting dynasty) and the provinces were tied more closely to the Egyptian centre. The ongoing struggle for supremacy now relocated to Cairo itself where the different households, which replaced the previous family ties as the future sultan's main power base, strove to impose their candidates. Yet, the household members did not advance the same claims to independent regional rule as the male family members had done under the Saljuqs.

\section{Historiographical background}

In their lifetimes, Ibn Wāșil and Abū Shāma witnessed this dynastic transition from the Ayyubids to the Mamluks. Ibn Wāṣil experienced it closely, owing to his intimate links with the military and administrative elites in Egypt, and Abū Shāma chronicled the events in his second main historical work, the Dhayl. As will be shown in this study, the Rawdatayn and the Mufarrij can also be read as reactions to these political developments. Both authors were concerned in their texts with the general question of what qualities characterized ideal rule, and by describing and evaluating the preceding reigns of Nūr al-Dīn and Șalāh al-Dīn, the authors also commented on the state of affairs in their own lifetimes.

The Mufarrij and the Rawdatayn are of special interest as they are the only works by Ibn Wāșil and Abū Shāma, which dealt with the same subject matter. Abū Shāma's other historical works were in general closer to religious issues in a confined meaning of the term. He wrote a polemical work against the Fatimids and summarized a biographical dictionary, which largely dealt with the religious scholars who had been resident in Damascus whereas Ibn Wāșil's works were chronicles, which dealt rather with the grand political events of the past. Obviously it is not possible to establish a clear-cut dichotomy (within the period's terminology) between religious and political/secular works. However, it is at least possible to differentiate between works written in a context of religious controversy or for the purpose of presenting the tradition of religious scholars on the one hand and works tracing the development of certain polities within the Islamic world on the other.

Abū Shāma's earliest historical work was the Dhayl, an annalistic chronicle from the year following Șalāh al-Dīn's death up to the year of Abū Shāma's death. Although it was entitled Dhayl to the Rawdatayn, it was rather a work which predated and paralleled the Rawdatayn. Pinpointing a specific date of writing for the Dhayl does not reflect the nature of the work: rather than having been finished at a 
set date, it was a kind of diary, which was updated regularly. In contrast with Abū Shāma's claim that he became interested in history only later in life (when composing the Rawdatayn in the late $640 \mathrm{~s} / 1240 \mathrm{~s})^{7}$ an early draft version of the introduction to the Dhayl, excluded from its final version, ${ }^{8}$ shows that his interest in history had started much earlier:

I started this chronicle with the death of [...] al-Malik al-Mu'azzam [d. 624/1227], the [Ayyubid] ruler of Damascus [...], because after that I witnessed affairs and was aware of the situation. On this date it came also to my mind to compose in the field of history. ${ }^{9}$

(Abū Shāma, Dhayl, BL or. 1539, fol. 49b)

The term Dhayl is not only misleading in its chronological connotations, but also in terms of content: in contrast to the Rawdatayn it examined the scholarly community of one town, Damascus, in detail, and relegated political events to a subordinate status in the narrative.

Abū Shāma's second historical work was an abridgement of Ibn 'Asākir's (d. 571/1175) biographical work, The History of Damascus. This dictionary followed the well-established genre of locally centred biographical dictionaries with an emphasis on religious scholars. Due to the popularity of this abridgement, but also arguably due to the similarity in its structure and content, a later author assumed that his Dhayl had been a continuation of this work, rather than of the Rawdatayn. ${ }^{10}$

A less well-known historical work was his summary of Muhammad al-Nasawī's (d. 647/1249-50) work Sìrat al-Sultān Jalāl al-Dīn Mingīrin̄̄ (The Biography of Sultan Jalāl al-Dīn Mingīiniñ). ${ }^{11}$ Al-Nasawī was an influential secretary at the court of the Khwārazm ruler Jalāl al-Dīn (d. 628/1231). In this work he considered the encounters between the Khwārazmshāhs and the Mongols in the eastern lands in the early seventh/thirteenth century. Abū Shāma entitled his work Nuzhat al-muqlatayn $f_{\bar{\imath}}$ akbbār al-dawlatayn al-'Alā'sya wa-al-Jalālīya (The Two Eyes' Entertainment on the Reports of the Two Rules of 'Alä'al-Dìn [d. 617/1220] and Jaläl al-Dīn). This summary was seemingly not popular, as biographical dictionaries failed to mention it, and only one manuscript has survived. ${ }^{12}$

Although no manuscripts of the Kashf mā kāna 'alayhi ban̄' 'Ubayd min al-kufr wa-al-kidbb wa-al-kìd (The Disclosure of the Unbelief, Deceit and Deception of the Ban $\bar{u}$ 'Ubayd [i.e. the Fatimids]) have survived, biographical entries often referred to it, as did Abū Shāma himself. From the title, and Abū Shāma's own reference to it, ${ }^{13}$ it is plain that it was an anti-Fatimid work. Since the establishment of the Fatimid caliphate in Egypt in the fourth/tenth century the literature aimed against this dynasty had become a well-established genre. ${ }^{14}$ As Abū Shāma was merely one of many authors writing polemics against a group which by the seventh/thirteenth century no longer posed a serious threat, it is, perhaps, unsurprising that no manuscript has survived.

Towards the end of his life Abū Shāma abridged his Rawdatayn in a small volume called 'Uyün al-Rawdatayn (The Essence of the Two Gardens). In it he omitted most of 
the poetry, which he had cited extensively in the Rawdatayn and occasionally integrated the different sources into a shorter narrative. Repeating that the main aim of his abridgement was to urge the rulers to follow the example described in the work, he seemingly hoped to spread his vision of the past further by producing this synopsis. ${ }^{15}$ Nevertheless, biographical entries hardly referred to the text, ${ }^{16}$ and only three manuscripts have survived. ${ }^{17}$ It was apparently never able to rival the popularity of the original. ${ }^{18}$

It is the Rawdatayn, which has been the most popular of all his historical writings. Abū Shāma wrote the Rawdatayn during the mid-640s/late 1240s. He started to teach it at the latest in 649/1251-2, ${ }^{19}$ but two years later revoked the versions previously taught and declared the new version to be the only authoritative one. ${ }^{20} \mathrm{He}$ taught it until his death, and few later biographers failed to mention it. ${ }^{21}$ The Rawdatayn was widely disseminated, as is evident from the nearly twenty extant manuscripts. ${ }^{22}$

The Rawdatayn dealt, in contrast to most of his other historical works, predominantly with the politico-military events of the late Zangid and early Ayyubid periods. Biographies were also largely devoted to individuals belonging to the military or administrative elite. Although religious scholars appear occasionally in the obituary notices, they play a minor role compared to his second main chronicle, the Dhayl. The Rawdatayn was written some fifty years after the death of Șalāh al-Dīn, and in writing it Abū Shāma was able to draw on an impressive corpus of texts on this period. ${ }^{23}$ Most important among them were the historical works by the Damascene scholar and administrator Hamza b. Asad Ibn al-Qalānisī (d. 555/1160), ${ }^{24}$ Ṣalāh al-Dīn's and Nūr al-Dīn's secretary 'Imād al-Dīn al-Ișfahān̄ì (d. 597/1201), ${ }^{25}$ the Mosulian historian Ibn al-Athīr (d. 630/1233), Șalāh al-Dīn’s judge of the army and administrator Ibn Shaddād (d. 632/1234), and the lost work by the Shiite administrator of the Aleppian ruler al-Malik al-Z̄āhir Ghāzī, Ibn Abī Ṭayy (d. 630/1233).

In contrast to Abū Shāma, Ibn Wāṣil stated unequivocally his long-lasting interest in the field of history in a note on the autograph draft version of Ibn Khallikān's biographical dictionary, which was in his possession: 'Muhammad [...] b. Wāṣil [...] says: Since I reached the age of understanding until today when I am over seventy years old, I have been enthusiastic about the art of history and the works written on it [...]. ${ }^{, 26} \mathrm{He}$ wrote his first historical work in the mid-630s/late 1230s. It was The Saalibian History, which he attempted to dedicate first to al-Malik al-Ṣālih and then to al-Malik al-Mu'aẓam Tūrānshāh. This chronicle was a universal history from the creation of the world down to the year 636/1239, the year in which Ibn Wāṣil's later patron al-Malik al-Ṣālị arrived in Damascus and briefly took power. It was a work in the tradition of earlier chronicles in that it contained hardly any obituary notices and focused on political events. Ibn Wāṣil himself claimed in an introduction written in the mid-640s/late 1240s that this work had been widely copied since its composition. ${ }^{27}$ The work was indeed mentioned in several biographical dictionaries, ${ }^{28}$ and has survived in three manuscripts. ${ }^{29}$

In The Șălibian History Ibn Wāṣil repeatedly expressed his intention to compose a more detailed history. When he explained that the work ended with the year 
636/1239, he stated that his aim was to write 'an exhaustive history, in which everything will be described in such detail, that there will not be anything mentioned in the famous histories, which is not in it' ${ }^{30}$ When he wrote the Mufarrij four decades later, he had seemingly completed this 'al-Ta'rikkh al-kabīr' (The Grand History) as he referred to it in the course of the text. ${ }^{31}$ But aside from this indirect evidence of its existence no manuscript has survived and biographical entries were generally not aware of it. ${ }^{32}$ To judge from The Șalibian History it was probably also a universal history focusing on political and military events. ${ }^{33}$

After Ibn Wāșil had returned to his home town Hama in the early 660s/1260s, he started to write his Mufarrij. Although the eighth-/fourteenth-century historian al-Dhahabī stated that Ibn Wāṣil had composed the work around 670/1271-2, ${ }^{34}$ the textual evidence reveals a more complex picture. The most probable scenario is that he worked on it over a period of several years between 670/1271-2 and 689/1290-1 at the latest. ${ }^{35}$ This work was his last historical one, and proved to be his most popular. He taught the Mufarrij as well as his other works in his study circle in Hama and also took the opportunity to teach them in other places, such as Cairo. Biographical entries about him invariably referred to this work, and it has survived in four - although incomplete - manuscripts.

The work's first parts dealt with the same events as Abū Shāma's Rawdatayn: the rise of the Zangid dynasty (including an extensive section on Nūr al-Dīn), and the rise of the Ayyubids under Șalāh al-Dīn. Ibn Wāṣil continued by including the Ayyubid history up to the mid-seventh/thirteenth century and the first decade of Mamluk rule. Even more than Abū Shāma's Rawdatayn, and like his own Saalibian History (and probably also the Grand History), it focused on politico-military events, with religious scholars appearing only very occasionally. For those sections of his work dealing with periods prior to his maturity, Ibn Wāṣil drew on sources similar to those used by Abū Shāma. Additional sources were those reflecting his background, such as the historical work by the Hamawian ruler al-Malik al-Manșūr (d. 617/1221), ${ }^{36}$ and later sources, such as most importantly the Rawdatayn. For the sections on the following periods he largely drew on his own experience and oral sources, such as the amir Husām al-Dīn al-Hadhabānī. ${ }^{37}$

Abū Shāma's Rawdatayn and Ibn Wāṣil's Mufarrij are thus the only works where these two authors, who had rather specialized in different fields of historical writing, composed a work on the same subject matter. These two authors not only differed with regard to the profile of their historical corpora in terms of religious and political content, but, as will be seen in the following chapter, they also differed strongly in their attitude towards the ruling elites of their period. Ibn Wāșil's concentration on politico-military events in his historical narratives was paralleled by a close integration with the leading administrative and military groups in Egypt and Syria; on the other hand, Abū Shāma's weaker interest in such events was reflected in a position which strongly rejected close interaction with those elites.

The nature of Abū Shāma's and Ibn Wāṣil's chronicles, and their position vis-à-vis the ruling dynasties, become more relevant in the context of the production of historical knowledge in Syria and al-Jazira in the seventh/thirteenth century. 
Although there is still a lack of specialized scholarship on these chronicles' authors, it is clear that most of them shared many similarities with Ibn Wāṣil.

Ibn al-Athīr, the author of a local chronicle amongst others, came from a family that had intimate links with the ruling elite of Mosul. ${ }^{38}$ His father was a high official of the court, his brother Majd al-Dīn worked as an official, and his brother Diya $\vec{a}$ al-Dīn served rulers in Mosul and was vizier to al-Af̣̣al, son of Șalāh al-Dīn, in Damascus. Ibn al-Athīr occasionally served as envoy from the ruler of Mosul to Baghdad. Ibn Shaddād (d. 632/1235), the author of a chronicle centred on Șalāh al-Dīn’s life, served him as a judge. After Șalāḥ al-Dīn's death he played an important role in missions between the various Ayyubid rulers. ${ }^{39}$ Ibn al-'Adīm (d. 660/1262), the author of a local chronicle of Aleppo served the ruler of the town as secretary, judge and vizier. ${ }^{40}$ Sibt b. al-Jawzī (d. 654/1256), the author of a universal chronicle, and Abū Shāma's compatriot in Damascus, joined the Ayyubid rulers of the town after he had settled in the town. ${ }^{41}$

Writing a chronicle of the immediate past in this period was an activity mainly confined to a group of authors who were in close contact with the ruling elites. Like Ibn Wāṣil, they either held posts in proximity to the court, or had close relationships with the elites centred on it. Such a one as Abū Shāma, who was at a distance from the courts (and emphasized this distance) was an exceptional case. It is therefore possible to read his chronicle as a rare expression of historical perception, which in the context of its production makes it stand out from the bulk of chronicles written.

This situation is also visible in these authors' profile of their historical corpora as they stayed in general rather within the genre of works focusing on grand political events. Apart from his local chronicle centred on political events, Ibn al-Athīr wrote a universal chronicle, al-Kāmil fi al-ta'rik $h$, which traced events from the beginning of the world up to his own time. ${ }^{42}$ Ibn al-'Adīm authored a biographical dictionary of the town of Aleppo which displays a certain emphasis on religious scholars. Nevertheless, in contrast to other local biographical dictionaries - such as Ibn 'Asākir's work on Damascus - it contained a wider variety of individuals, including a significant proportion of rulers and members of the military elite. ${ }^{43}$

Biographical works centred on religious scholars, or chronicles mainly written for polemical reasons, were not typical of this group of authors. In Khalidi's terms this trend in historiography could be labelled as early 'siyāsa history'. Starting with the fifth/eleventh century, authors of historical works were brought closer to the ruling elites. This closer connection between power and knowledge brought about a stronger interest in governance as the main subject of historical inquiry. ${ }^{44}$

Abū Shāma's Rawdatayn was the work with which he entered a genre rather atypical of an author seeking to distance himself from the ruling elites. With regard to the form (annalistic chronicle) and content (rulers of the immediate past with a focus on politico-military events) this narrative showed the largest degree of similarity to the majority of chronicles produced in this period. A comparative reading of Abū Shāma's and Ibn Wāṣil's works will show that their different historical and historiographical backgrounds are also evident in the different, or even opposed, visions of the past which underlay their chronicles. 


\section{SOCIAL CONTEXTS}

Ibn Wāșil ${ }^{1}$ dedicated historical and other works to his ruling patrons. ${ }^{2}$ He composed his universal history, The Sălibian History, for the Ayyubid ruler al-Malik al-Ṣālih Ayyūb. As the ruler died shortly before Ibn Wāsil was able to present it to him, he then dedicated it to al-Ṣālih’̣ son and successor al-Malik al-Mu'aẓzam Tūrānshāh. Once again the attempt failed since the young ruler was murdered shortly before he was due to receive both this work, and one of Ibn Wāsil's astronomical works. ${ }^{3}$ Before that, however, Ibn Wāșil had been more fortunate in presenting Tūrānshāh with his universal history, Nażm al-durar $f^{\bar{\imath}}$ al-ḩawädith wa-al-siyar (The String of Pearls Concerning the Episodes and Biographies). He also dedicated a treatise on logic, al-Risala al-Anbrüriya (The Imperial Treatise) to the Staufer ruler of Sicily Manfred (d. 664/1266), son of Frederick II, when he stayed at his court in southern Italy in 659/1261. ${ }^{4}$ He thus followed the example of a number of other Arabic-speaking scholars, who had dedicated their writings to the Christian rulers of these regions in the aftermath of the Norman conquests in the fifth/eleventh century. ${ }^{5}$ Later in his life in Hama, Ibn Wāșil dedicated a summary of the poetic encyclopaedia Book of Songs by Abū al-Faraj 'Alī al-Iṣfahānī (d. 356/967), Tajrìd al-Aghān̄̄ as well as his main chronicle, the Mufarrij, to the ruler of the town.

It is for this reason that the latter work has been described as a 'panegyric' for his patron and his patron's dynasty, the Ayyubids. ${ }^{6}$ This description has been based not only on the text itself but also on a specific view of the scholars' position in society. Medieval critics of those scholars who were in contact with rulers had already feared that those contacts might result in the loss of the scholar's integrity. The fear was no doubt reinforced by pleadings, such as Ibn Wāṣil's to his patron, al-Malik al-Manșūr Muhammad (d. 683/1284), the ruler of Hama, not to stop payments to the ruler's entourage in the month of Șafar, as had been his custom:

O master! The star of his good fortune is still looming in the celestial sphere highly above the other stars.

Your overflowing benevolence is an everlasting spring so why should it be in Safar proscribed? ${ }^{7}$

(al-Suyūṭ̂̄, Bughya, I, 108-9) 
Thus, when we deal with a 'court historian' like Ibn Wāṣil, the question arises: did the social context of his time allow him room for manoeuvre in the writing of his narrative, or was his dependency so direct and unmediated that the narrative could not be anything but a reflection of his patron's outlook, a panegyric?

In modern scholarship the issue of the scholar's social position in his society has been taken up in two different ways. On the one hand, social relations in pre-modern Middle Eastern societies have been discussed with reference to institutions. In this regard, Middle Eastern societies, in contrast to those of Europe or China, ${ }^{8}$ purportedly developed less differentiated institutions (e.g. church or state-bureaucracy), displayed a lesser degree of hierarchical stratification and developed a less clear definition of the status of elite groups. According to this view the respective ruler disposed of a high degree of autonomy in relation to other groups in society, ${ }^{9}$ and was also able to bring the group of scholars into an unmediated relationship of dependency. ${ }^{10}$ As regards history writing, Rosenthal suggests that this led to a situation in which ' $\mathrm{t}$ ] hey [the Muslim historians] often were in the service of a ruler, and their work was slanted often very crudely - to reflect his political interests'. ${ }^{11}$ Khalidi (1994) makes the same assumption where 'social context' is often understood as being equal to 'relationships of dependency'. ${ }^{12}$

This approach to describing Middle Eastern pre-modern society largely in terms of the absence of institutions, which did exist in other geographical areas, has in other studies been exactly reversed. Authors such as Havemann have attempted to define a number of institutions which might have enhanced the degree of agency in the social practice of groups below the highest ruling elite level within society. ${ }^{13}$

The madrasa is a case in point: it is of particular relevance in the current context, since both Ibn Wāṣil and Abū Shāma held a number of appointments in these seats of learning. Madrasas started to spread to Syria and Egypt from their origins in the Islamic east during the sixth/twelfth century. ${ }^{14}$ Before the rise of madrasas, learning and teaching had mainly been practiced by individuals pursuing their intellectual activities in tandem with more mundane careers, such as trade, since positions that offered payment to religious scholars (e.g. judges $(q \bar{a} d \bar{\imath})$ or censors/market inspectors (mubtasibs)) had been few. An alternative 'career' for these scholars was to depend on the less formal patronage by rulers and members of the elite. The development of the madrasa, however, offered for the first time large numbers of paid positions for teachers, and provisions for students. The social effect of this change was considerable as more scholars were able to concentrate exclusively on their scholarly pursuits. ${ }^{15}$

This change has been seen as part of a post-'Abbasid development bringing scholars closer to, and in more direct dependency upon, the rulers. In this sense, the foundation of madrasas is considered as a state-sponsored activity - with the state providing the financial means through endowments (waqfs). ${ }^{16}$ The madrasas themselves have been described as highly stratified institutions with clearly shared characteristics (e.g. with regard to the curriculum $)^{17}$ developing under military dynasties such as the Saljuqs, the Zangids, the Ayyubids or the Mamluks. This rise is seen to have limited the independence of scholars at the same time that it changed 
the shape of their societies in general by increasing the ruling elites' autonomy. ${ }^{18}$ To quote Khalidi:

The ruling military elites, having monopolized political power, constantly interfered in the economic, social and religious life of their subjects. A high degree of bureaucratization and hierarchization of society as a whole became visible, largely in order to facilitate control.

(Khalidi (1994), 183)

So, although pre-modern Middle Eastern society has been largely described with regard to the question of existence or absence of institutions, the conclusion regarding the question of agency in the social practice of individuals below the level of the ruling elites has nevertheless been similar: those individuals disposed of a low degree of agency in their acts. This limitation purportedly resulted from arbitrary interventions of the ruling elite or from subjecting them to stratified institutions.

On the other hand a number of studies have departed from this institution-centred approach and focused more on the issue of social practice by the different actors involved. With regard to the issue of madrasas it has been argued that their development cannot be seen as a state-sponsored initiative. The founding of a madrasa was mainly a private endeavour, where even the endowing rulers acted rather as individuals and not in their ruling capacity. ${ }^{19}$ Furthermore, the practice of learning and teaching did not fundamentally change, but largely remained a personal affair between individual teachers and students. Far from an institutionalized system of teaching and learning, there developed instead a very broad material framework of buildings and endowments, within which the traditional forms of a highly personalized student-teacher relationship continued. ${ }^{20}$

In this connection two key studies on different periods and regions have to be mentioned. Lapidus (1984) describes the development of towns in Syria and Egypt during the Mamluk period not in terms of formal government and legal institutions, but in terms of the social relationships among individuals, classes and groups, which was the crucial factor in the governance of these towns. Mottahedeh (2001) discusses the social structure in the Muslim east during the Buyid dynasty in the fourth/tenth and fifth/eleventh centuries, arguing inter alia that it survived despite the absence of formal institutions, because of the different bonds which existed between individuals and within groups. ${ }^{21}$ Although his study focuses on patron-client relationships, it touches upon the central concern here, namely the question how scholars could attain stable positions in a society devoid of formal institutions.

In the tradition of these studies, Paul (1996) suggests in his analysis of eastern Iran and Transoxania in the pre-Mongolian period that the role of central rule (or the 'state') in society was more circumscribed than previously assumed. Even in fields such as irrigation or military systems, local and regional actors played often the decisive role. Consequently, the spatial and social organization of society and rule was only to a low degree institutionalized; he also stresses here the importance of 'networks' to the society's structure. ${ }^{22}$ 


\section{Ibn Wāṣil - patronage and networks}

In order to move beyond the institution-centred focus in the description of the social world of an individual scholar such as Ibn Wāșil, the following description takes up the concept of networks. The network approach has been developed mainly in social sciences as an attempt to describe informal social interaction. ${ }^{23}$ Since then it has moved to different fields, including Islamic history, ${ }^{24}$ where Lapidus first used it in a mainly positive sense. ${ }^{25}$ One of the main features of the concept of networks is the low importance ascribed to fixed categories such as a specific profession, which have been seen as determinative for an individual's social context in structuralist approaches. Network approaches focus rather on an individual's capacity to act independently within a given context. In this sense members of the ruling elite are, with regard to their social actions, not primarily seen as forming a greater entity, 'the state', but rather as participants in the building and sustaining of specific networks. Belonging to a certain group or acting within a specific institution is not seen as a limiting factor in an individual's environment. On the contrary, the focus is on the individual's ability to enlarge his agency in social interaction by drawing, depending on the actual situation, on one or several of these 'formal' aspects. ${ }^{26}$

With regard to Ibn Wāsil, this means that the focus is not on seeing him as an individual whose position is mainly determined by formal structures such as his holding of teaching posts; the aim is rather to include in the description his belonging to an 'informal' network. Ibn Wāșil is considered in the following as an individual who was able to display in his acts individual agency, but was simultaneously limited by his environment. The present discussion considers his agency and the limitations with regard to his social context, while the following chapters will consider these aspects with regard to his cultural environment.

'Network approach' is understood and applied here as a 'perspective' enabling reconsideration of an individual's social position. The aim here cannot be to offer a relatively comprehensive model of social interaction for the period under consideration which would in any case be impracticable given the lack of a relatively reliable empirical basis. However, it is possible to identify points of contact between specific individuals. It is, perhaps, even possible to describe the role of specific groups in networks, such as the religious scholars, who are the best-documented group of this period. Nevertheless, the patchy evidence renders more far-reaching descriptions impossible; it is hardly feasible to describe whole networks - which included different sections of society - especially those below the elite level. It is my contention that the description of an individual's social context, such as Ibn Wāṣil's, must also include his position with regard to individuals outside the scholarly community of his time. In his case it is possible, based on his own writings, to ascertain his relationships with elite-level individuals, such as amirs or secretaries. However, the absence of similar source material for many of his contemporaries precludes any far-reaching statements about this network as a whole or the description of possibly competing networks. In network discourse, we are left with a bundle of egocentric networks, where the absence of relations between actors is not necessarily linked to 
structural holes, but arguably to missing evidence. The network described in the following pages includes only members of the scholarly, administrative and military elite, while links to popular sections of society are not included. This, not because they were irrelevant or nonexistent, but because the source material does not allow for investigation of this aspect.

Apart from this empirical problem, the principal problem on a qualitative level is that even if contacts can be ascertained, there is a lack of conceptual terms proposed in secondary literature defining the nature of such contacts. It is somewhat unsatisfying when the description of bonds is limited to the statement that they existed, without a consideration of what their quality was. Makdisi (1981) is a rare exception to this, as he conceptualizes the quality of relationships between scholars. He especially applies the concept of subbalmuläzama (companionship) to student-teacher relationships. The latter two terms are then defined as the notion of following or adhering to a master in a constant and exclusive way, devoting [oneself] to working under his direction'. ${ }^{27}$ The subbalmulazama relationship was the crucial element in Islamic education, according to Makdisi, particularly in the period before the development of the madrasa. Just the same, Makdisi's conceptualization is limited to relationships between individuals within this one specific group. With regard to contacts crossing the borders of societal groups, for example, between a scholar and an amir, a similar conceptualization has not yet been suggested. ${ }^{28}$

It is my contention that the subbalmulazzama relationship was not only of importance in the educational field, but that it was also an important bond between individuals in other social fields. Suḅbalmulāzama was employed in medieval texts, besides mawadda (friendship), to describe a number of relationships between individuals from different groups. Sub̧balmuläzama relationships could exist between a preacher $\left(w \bar{a}^{\prime} i z\right)$ and a trader, ${ }^{29}$ a younger and a more experienced trader, ${ }^{30}$ a jurisconsultant and an $\mathrm{amir}^{31}$ or between two amirs. ${ }^{32}$ Its use to describe these bonds expressed the highly personalized nature of relationships within formative and medieval Islamic society as a whole. Such bonds between individuals, belonging to the same or different social groups, were characterized by four main features:

1 Similar to Makdisi's understanding of the terms, it often contained some degree of hierarchy: the one partner accompanied the other socially stronger partner, or became attached to him. In contrast to a friendship (mawadda) which existed 'between' two approximately equal partners ('there was friendship between me and him' (wa-kāna baynañ̄ wa-baynabu mawaddat $\left.{ }^{a n}\right)$ ), companionship occurred in a directed way from one person 'to' another ('I accompanied him' (sāhabtubullāzamtubu)). This could even mean that the relational part of an individual's name (nisba) was derived from the person he accompanied. ${ }^{33}$

2 Sub̧balmulāzama was characterized by a degree of formalization. It was not only, as argued by Makdisi, a stable relationship, but also one into which one entered at a specific point of time. For example, the Egyptian administrator and poet Bahä al-Dīn Zuhayr (d. 656/1258), was pleased by the writing and words of a young secretary serving another ruler. He called him and 'asked him: "What would you say to 
accompanying me and becoming my deputy?" He [the secretary] agreed and accompanied him. ${ }^{34}$ A friendship, on the contrary, was generally described in vague terms, without a clear delimitation in time. The scholar and biographer Ibn Khallikān (d. 681/1282), for example, stated with regard to his bond with the same Bahä al-Dīn Zuhayr, that 'there was friendship between us', without any further details given. ${ }^{35}$

3 As shown by Makdisi in the educational context, a suḅbalmulāzama bond was characterized by a certain degree of mutual exclusivity. ${ }^{36}$ This mutual exclusivity was more accentuated the more socially equal the partners were. Between such partners one rarely encounters an individual being involved in more than one such relationship at a time. The subbalmulāzama bond between the scholar Jamāl al-Dīn Muhammad (d. 707/1307) and Najm al-Dīn Muhammad (d. 695/1296) had been so close that the Mamluk biographer Ibn al-Ṣqua $\bar{a} \overline{1}$ treated them, exceptionally for the form of biographical dictionaries, in a shared entry. ${ }^{37}$

A suḅbalmulāzama bond between two socially unequal partners, on the contrary, tended to be less exclusive from the point of view of the higher-ranked individual; from the perspective of a ruler, for example, it could obviously not be exclusive. From the point of view of the inferior, on the other hand, it certainly was, at least until the relationship was dissolved. In such cases the relationship was often described in combination with the terms 'attachment' and 'service', for example, 'I became attached to his service [lāzamtu khidmatabu]'. ${ }^{38}$

4 Sub̧balmulāzama yielded concrete advantages, which might be expected from one or both sides. For example, Bahä al-Dīn Zuhayr and the amir-administrator Jamāl al-Dīn b. Mațrūh (d. 649/1251) were described as being 'among the most complete persons with regard to generosity and care for those who were close to them and accompanied them'. ${ }^{39}$ This was visible when the young secretary who had entered the service of Bahā' al-Dīn's patron al-Malik al-Șālih Ayyūb on the former's invitation at one point committed a serious mistake which seriously compromised the ruler. Bahă al-Dīn took the responsibility for this mistake, in order to cover his companion, and subsequently lost his position. ${ }^{40}$ Equally the wealthy Syrian trader Ibn 'Amrūn was said to have 'protected those who accompanied him and [to have] provided for their subsistence.' ${ }^{41}$

Thus, sub̧balmulāzama bonds were social links between two individuals, which tended to be hierarchical, formalized, exclusive and advantageous. They constituted a central aspect of the social contexts of individuals. The different social background of the individuals with whom Ibn Wāṣil on the one hand, and Abū Shāma on the other, built such relationships is a clear indicator of their different social milieus.

In the course of his life Ibn Wāṣil held different teaching and juridical posts. His first teaching position was in the Shāfi ite Nāṣirīya Madrasa in Jerusalem, where his father had been appointed in $622 / 1225$ by the Damascene ruler al-Malik al-Mu'az̧zam 'Īsā (d. 624/1227). ${ }^{42}$ In 624/1227, when his father left for the pilgrimage to Mecca, Ibn Wāṣil took over as his father's substitute (n $\left.\bar{a}^{\prime} i b\right)$ for at least a year. ${ }^{43}$ In 644/1246 al-Malik al-Ṣālih Ayyūb gave him the teaching position in the Aqmar Mosque in Cairo (al-Qāhira). In 655/1257 the Mamluk ruler al-Malik al-Manșūr b. Aybak appointed him as judge in Gīza and Aṭfīh. ${ }^{44}$ In 658/1260 
al-Malik al-Z̄âhir Baybars (d. 676/1277) appointed him teacher (mudarris) in the Shāfi'ite zāwiya ${ }^{45}$ of the principal mosque in Cairo (Mișr). ${ }^{46}$ The same ruler also sent him as envoy to the Staufer court in Sicily, and Ibn Wāsil furthermore continued to teach informally while he was chief judge (qāa $\bar{\imath} a l-q u d \bar{a})$ in Hama, after he had returned there in the early 660s/1260s ${ }^{47}$ Rulers made all of his appointments either directly (al-Aqmar, Gīza and Ațî̀h, zāwiya) or indirectly (Jerusalem where the ruler had appointed his father, who in turn appointed him as his substitute). It was also a ruler, al-Malik al-Manșūr Muhammad, who appointed him as chief judge of Hama. Taken together with the fact that he dedicated many of his works to rulers, Ibn Wāṣil clearly appears as a dependent 'court scholar' par excellence.

The impression created by this brief review of his career $^{48}$ can be qualified by shifting the focus away from the issues of formal positions towards the network approach outlined in the previous section. This shift shows that Ibn Wāșil succeeded in building a stable social position during his life, relatively independent from specific rulers, by forging links with members of the scholarly, administrative and military elite. It was these links which were the crucial element in his social world. Figure 1 in the Appendix shows Ibn Wạșil's connections with individuals from the different sections of society with whom he forged links at different stages in his life: rulers, scholars and members of the military or the administrative elite.

In the twenty years or so following his substitution for his father in Jerusalem he moved between different towns within Syria, partly in order to pursue his education, and partly in order to integrate himself into the entourages at different courts. His family background continued to play a decisive role in these steps. Not only did his father remain of continuous importance until his death in 629/1232, but Ibn Wāṣil was also in close contact with his maternal relative Shihāb al-Dīn Ibn Abī al-Damm, the chief judge of Hama in those years. Between 629/1231 and his move to Egypt in $643 / 1245$, we find him holding positions at the courts of al-Karak (twice), Hama (twice) and being in the entourage of the Damascene ruler al-Malik al-Șālih Ayyūb, his later patron in Egypt. It is remarkable that he moved with such seeming ease between the different towns and courts; there are no indications that he was forced to leave in any of the instances. The assumption of an unhindered movement between different courts is supported by the fact that he was able to return to courts where he had previously been.

It seems that as much as he needed paid positions, these were offered to him without demanding long-lasting commitment. This seventh-/thirteenth-century scholar had great freedom of choice with regard to where, and with whom, he wanted to pursue his activities. It was only the choice of the rival of a former patron, which led to conflict. In 641/1244 Ibn Wāṣil left Hama and moved to Egypt as he could no longer expect 'the fulfilment of all hopes' 49 due to the fatal illness of his patron, the town's ruler. En route he stayed briefly in Jerusalem; while there he discovered that al-Malik al-Nāṣir Dāaù (d. 656/1258) of al-Karak, who had been his patron seven years earlier, was nearby. Ibn Wāṣil avoided meeting him in order not to be dissuaded or prevented from moving to al-Malik al-Nāṣir Dāùū's main opponent al-Malik al-Ṣālih Ayyūb, who had become ruler of Egypt in the meantime. ${ }^{50}$ 
Ibn Wāṣil's stable social position, with relative independence from rulers, can be explained by considering the years following his arrival in Egypt in the 640s/1240s. This period is of particular interest as his family, which arguably played an important role during his first 4 and final 3 decades in Syria could not have played a significant role during his stay in Egypt. In 644/1246 al-Malik al-Șālih Ayyūb, the ruler of Egypt, appointed Ibn Wāṣil as mudarris in the Aqmar Mosque ${ }^{51}$ which was situated within Cairo in al-Qāhira, the former royal city of the Fatimids, and which had now become the prestigious centre of the civilian elite. In the Fatimid period the Aqmar Mosque had been part of one of the central sites of the town's topography. Placed along the main axis' (the Great Street) central site, Between the Two Palaces, the location enjoyed considerable prominence as a commercial and official focal point. The area remained an important site even during the Ayyubid and Mamluk periods, despite the move of the rulers' residence from this site to the newly built citadel on a spur of the Muqațam hills outside the Fatimid city at the end of the sixth/twelfth century. Before and after the move a number of madrasas and mausoleums for rulers were built around this site in what became one of the residential areas for amirs. Most significantly, al-Malik al-Ṣalih Ayyūb chose the area as the site where he built his large madrasa in 641/1243-4. ${ }^{52}$ Despite its minor religious significance, compared for example to other mosques such as the 'Amr or the Azhar Mosques, the Aqmar had a prominent place within the social and political texture of the late Ayyubid/early Mamluk town.

This prominence is apparent if we consider Ibn Wāṣil's predecessors in the Aqmar Mosque. Ibn Wāṣil followed 'Abd al-'Az̄iz b. 'Abd al-Raḥmān (d. 643/1245-6), ${ }^{53}$ a scion of the great Syrian scholarly family, Ibn Abī 'Așrūn. ${ }^{54}$ In the early decades of the seventh/thirteenth century his father had been chief judge in Hama, where he played an active role in local politics. 'Abd al-'Azīz himself moved to Egypt after imprisonment and expulsion from Aleppo due to some unidentified incident. In Egypt, he entered the service of al-Malik al-Șālih and served repeatedly as his envoy to the caliphal court.

'Abd al-'Azīz's own predecessor as mudarris in the mosque was 'Uthmān b. Sa'īd (d. 639/1241), a Shāfi'ite scholar who had come from the Maghrib to Egypt in his youth. After a career as a judge in the provincial town of Qūs, he settled in Cairo. There, he rose to prominence in the 'Amr Mosque (or al-Jāmi' al-'Atīq) in Cairo (Miṣr), the first mosque to be built in the old Fustāṭ, and still in this period a flourishing centre of religious instruction. Finally he was appointed assistant of the treasurer (wakīl bayt al-māl) ${ }^{55}$ and mudarris in the Aqmar Mosque. ${ }^{56}$

In his chronicle Ibn Wāṣil cited his decree of nomination (tawq $\bar{\imath}^{`} b i$-tadrīs) and gave some introductory comments. ${ }^{57}$ The parts of the text he cited state in rather conventional terms the right-guidedness of the ruler, Ibn Wāșil's learning, the decision to appoint him as mudarris, his duties and some technical matters. From this decree it appears, as might be expected, that the appointment was exclusively the decision of the lofty ruler himself, although in the preceding paragraph Ibn Wāșil offered some more detailed clues to the nomination process. As was usual for such a position, the process was by competition: 'When he [the previous mudarris] died, a 
number of the prominent scholars ( $\left.a^{c} y \bar{a} n\right)$ demanded this teaching post.' The competition may have been particularly strong on this occasion due to the fact that in addition to this teaching appointment the predecessors had held administrative posts and had acted as diplomatic envoys. Hence, the Aqmar post seemed a promising stepping-stone for a further career in the administrative elite.

Ibn Wāṣil himself stated that al-Malik al-Șālih Ayyūb had decided that he should receive the position after 'I was mentioned [to him].${ }^{58}$ This sentence becomes more meaningful when considered in the context of his network at the court; Figure 2 in the Appendix illustrates his network in the Egyptian court during his stay there under different rulers. It represents his network (including all identifiable links) during a specific period of his life, and is in this sense an enlarged and expanded detail of Figure 1.

Fakhr al-Dīn b. Luqmān (d. 693/1293) (the erring young secretary mentioned earlier in the general section on șubbalmulāzama bonds), wrote Ibn Wāșil's decree of nomination. ${ }^{59}$ Bahä al-Dīn Zuhayr, the ruler's chief of chancery $\left(k \bar{a} t i b \text { al-insh } \bar{a}^{\prime}\right)^{60}$ and friend of Ibn Wāṣil, had brought Fakhr al-Dīn to al-Malik al-Șālih Ayyūb’s court after these two secretaries had entered their șụ̧balmulāzama relationship. ${ }^{61}$ Ibn Wāṣil had been on friendly terms with Bahā' al-Dīn since his Syrian days. In the mid-630s/ late 1230s Ibn Wāṣil had become acquainted with the entourage of al-Malik al-Ṣālih Ayyūb at Damascus (r. 636-7/1239) and presumably enjoyed the ruler's favour.

It was Husām al-Dīn al-Hadhabānī (d. 658/1260) who was Ibn Wāṣil's point of entry to the ruler's entourage. ${ }^{62}$ Ibn Wāṣil became linked to him by a suḅbalmulāzama relationship from 636/1238-9 onwards. ${ }^{63}$ Husām al-Dīn had begun his career as amir in Ibn Wāsilil's home town of Hama; his family belonged to the town's military elite, just as Ibn Wāṣil's family belonged to the civilian/religious elite. Husām al-Dīn entered the service of al-Malik al-Șālih Ayyūb after a conflict with the ruler of Hama, al-Malik al-Muẓaffar Mahmūd (d. 642/1244) in the mid-620s/1220s. Here, he rose quickly, becoming one of the closest advisors of the ruler, tutor (atäbak) of his young son al-Malik al-Mu'aẓzam Tūrānshāh in Hisn Kayfa and al-Malik al-Ṣālih Ayyūb’s mayor of the palace (major-domo, ustādh al-dār). ${ }^{64}$ In 644/1246-7 we find him as deputy (na'ib al-salțana $)^{65}$ in Egypt, while the ruler was absent in Syria. The close relationship between him and Ibn Wāṣil is clear from the fact that Ibn Wāṣil stayed in his house after he had arrived in Egypt in 643/1245, and that both performed the pilgrimage to Mecca together in 649/1252. Ibn Wāṣil's move to Egypt was arguably linked to the fact that Husām al-Dīn was in the process of regaining his position in the entourage of al-Malik al-Ṣālị̣ Ayyūb. In 641/1243 he had been released after four years in captivity in Baalbek under the Damascene ruler al-Malik al-Ṣālị Ismā'̂̄l (d. 648/1251), during which Ibn Wāṣil had visited him repeatedly. ${ }^{66}$

On his arrival in Egypt Ibn Wāșil met also Jamāl al-Dīn b. Maṭūḥ (d. 649/1251). ${ }^{67}$ He was for certain periods the chief of the army's office (näzir al-jaysh) and treasurer (nāzir al-kbizānalnāzir bayt al-māl) to al-Malik al-Ṣālih Ayyūb. As with Husām al-Dīn, he had been with the ruler in the east before his accession to power in Egypt, and had followed him on his way to Egypt via Damascus. Being one of the ruler's closest advisers, he became vizier in Damascus in 643/1245, and until he fell 
out of al-Malik al-Ṣālị Ayyūb’s favour in 646/1248-9 he was among the most influential individuals in his entourage. Ibn Wāṣil had first met him in the mid-630s in al-Malik al-Ṣalih Ayyūb’s camp, probably via Husām al-Dīn. After al-Ṣālih Ayyūb's temporary fall in 637/1239, Jamāl al-Dīn b. Maṭrūh moved to Hama where Ibn Wāṣil visited him often and was also his teacher. Ibn Wāṣil referred to his relationship with Jamāl al-Dīn as being one of close intimacy and regular meetings. ${ }^{68}$

Jamāl al-Dīn b. Mațrūh and the chief of chancery Bahầ al-Dīn Zuhayr had been close friends since their youth. Both originated from Upper Egypt, where they rose through a number of posts at different courts. Ibn Khallikān described their subbalmulāzama bond as so close that they were 'like brothers' ${ }^{69}$ Like Husām al-Dīn and Jamāl al-Dīn b. Mațūh, Bahā' al-Dīn had been with the ruler in the east and followed him on his move to Egypt. ${ }^{70}$ He was close to the ruler, accompanied him on most campaigns and served occasionally as his envoy: 'He possessed great influence with his master, who esteemed him highly and never entrusted his secret to anybody else. ${ }^{71}$ Ibn Wāṣil had met him also in the mid-630s while accompanying Husām al-Dīn on a campaign in Syria. In his Mufarrij he included some poetry by Zuhayr, who was among the most acclaimed poets of his time.

Ibn Wāṣil extolled Jamāl al-Dīn b. Maṭūḥ and Bahā̄ al-Dīn Zuhayr repeatedly as having been unique in Ayyubid history and beyond. According to him the administrator al-Qāộ̄ al-Fāọil was outstanding in Șalāh al-Dīn's time, but there was no-one to equal al-Qāộ̄ al-Fāḍil's administrative skills. ${ }^{72}$ Taken together, Husām al-Dīn, Bahā' al-Dīn and Jamāl al-Dīn b. Mațūh were of particular importance in al-Malik al-Ṣālih Ayyūb's entourage. ${ }^{73}$

Thus, Ibn Wāṣil's move to Egypt can be considered in the light of his network at the court of al-Malik al-Șālih Ayyūb. He disposed of a closely knit set of connections, mainly made up of individuals who did not belong to the group of religious scholars, but were either military commanders or administrative officials. The most outstanding relationship was his ṣuḅbalmulāzama bond with Husām al-Dīn. It was arguably Ibn Wāṣil's network centred on this trio, rather than his relationship with the ruler, which allowed him to gain paid positions in Egypt, such as the teaching post in the Aqmar Mosque.

Towards the end of the Ayyubid period, however, all three disappeared from the court. Jamāl al-Dīn b. Mațrūh died in 649/1251, shortly after he had lost his position. Bahä al-Dīn left Egypt for Syria in the late 640s/1240s, after losing his position, and died in 656/1258 in poverty in Egypt. Husām al-Din lost his high position after the ruler's death in $647 / 1249$, refused the chance to become supreme military commander in the 'interregnum' between the Ayyubids and Mamluks after 648/1250 and finally retired with honours to Damascus in 651/1253-4.

In contrast, Ibn Wāṣil remained in his teaching post in the Aqmar Mosque and received a new position as judge in Gīza and Ațfīh in 655/1257. When he was additionally appointed three years later as teacher in the zäwiya in Mișr (Cairo), he continued to hold his two existing posts. ${ }^{74}$ Finally, in 659/1261 he went as an envoy from Egypt to Sicily. During the early Mamluk period Ibn Wāṣil was as much part of the Egyptian elite as he had been in the preceding Ayyubid period. When the 
Mongols moved into Syria in 658/1260 he participated in a meeting of the leading Egyptian personalities who had been assembled by the ruler for consultation. ${ }^{75}$ Neither the dynastic change from Ayyubids to Mamluks, nor the fall of several crucial individuals in his network decisively changed the course of his life. This social survival was linked to the fact that he had been able to compensate for the disappearance of some outstanding individuals from his network by extending it to members of the elite who gained in importance during the early Mamluk period.

The shift began at the death of al-Șālih Ayyūb, in the midst of the invasion of Egypt by the Seventh Crusade, when al-Malik al-Mu'az̧zam Tūrānshāh arrived to succeed his father, only to be murdered by the Bahri Mamluks shortly afterwards. Ibn Wāṣil had been introduced to the ruler by Husām al-Dīn,$^{76}$ the atābak of Tūrānshāh during his youth in al-Jazīra. However, Husām al-Dīn soon became one of the many military lords to be alienated by him, being set aside. Ibn Wāṣil, on the other hand, entered the entourage of this ruler and became close to him. ${ }^{77}$

In the crisis following the murder of Tūrānshāh, when the transition to the Mamluks was slowly taking place, Husām al-Dīn found it prudent to perform the pilgrimage (bajj) in 649/1252. Ibn Wāșil and a third individual, 'Izz al-Dīn al-Afram (d. 695/1295), accompanied him on this journey. 'Izz al-Dīn was a military commander of the Bahri regiments, and under the Mamluks became wāli of the upper-Egyptian town of Qūs in the early 650s/1250s. He received the command of the royal household guard (amīr jāndār) under al-Malik al-Z̄āhir Baybars and with only short interruptions kept this post until his death. During this period he also acted as the ruler's deputy when he was absent. As was typical of the late Ayyubid and the following Mamluk period, he also took over a number of functions, which during the preceding period had tended to be carried out by civilians. His responsibilities included undertaking construction works, the administration of endowments (waqfs), cultivated lands, questions of inheritance and others. He is said to have held 1/8 of Egypt as $i q t \bar{a}^{c} \cdot{ }^{78}$ Ibn Wāsil's association with such a rising star in the emerging Mamluk sultanate was a key element in the new network he contrived to establish within the changing military and administrative elite.

Another military commander, with whom Ibn Wāṣil was connected, was Jamāl al-Dīn Aydughdī (d. 664/1265). ${ }^{79}$ This amir played an outstanding role, especially under Baybars, who made him one of his trusted men, and gave him a considerable $i q t \bar{a} \bar{a}^{c}$. The ruler relied on his advice, particularly with regard to religious affairs and the appointment of judges. He was, for example, seen to have been influential in the introduction of a chief judge to each legal school (madhbab) in the Mamluk realms in 663/1265. ${ }^{80}$ Ibn Wāṣil was linked to Jamāl al-Dīn Aydughdī through friendship and was present when Aydughdī was briefly arrested in his camp in 653/1255-6 because of his presumed involvement in a conspiracy against the then ruler Aybak. ${ }^{81}$

As well as these military commanders, Ibn Wāṣil was also in contact with the vizier Sharaf al-Dīn al-Fā'izī (d. 655/1257) (2) $^{8}$ who served the first Mamluk ruler Aybak for six years. He had been the successor of Jamāl al-Dīn b. Maṭrūḥ as vizier of al-Malik al-Șālih Ayyūb in Damascus. When the latter's son, al-Malik al-Mu'az̧ạam Tūrānshāh, passed through Syria on his way to taking power in Egypt in 647/1249, 
Sharaf al-Dīn entered his service and became his vizier. Ibn Wāṣil became probably acquainted with him in the entourage of al-Malik al-Mu'aẓam Tūrānshāh. It is this replacement of the Husām al-Dīn, Jamāl al-Dīn b. Maṭrūh and Bahăà al-Dīn trio under the Ayyubids with the 'Izz al-Dīn, Jamāl al-Dīn Aydughdī and Sharaf al-Dīn trio under the Mamluks, which assured Ibn Wāṣil of his social long term position.

Shifting the focus to the group of religious scholars with whom Ibn Wāṣil was possibly in contact during his years in Egypt, we encounter a vaguer picture. His co-student from the Syrian years - the judge Ibn Khallikān - and three of his teachers from this period - the chief herbalist Ibn al-Baytar (d. 646/1248), the chief physician Ibn al-Nafīs (d. 687/1288) and al-Khūnajī (d. 646/1248), the judge of Cairo (Mișr) were in Egypt during Ibn Wāșil's time there. However, there is little indication that he was directly in contact with them. ${ }^{83}$ While one can assume that they played a role in his social world, there is hardly concrete evidence of this.

This might partly be a result of the source material at our disposal for this period of Ibn Wāșil's life. Most of the information about his contacts comes from his own narrative, which focuses on politico-military affairs. All the same, it is significant that hardly any of his teachers, and none of his students are traceable from Ibn Wāṣil's time in Egypt, whereas one would normally expect to find such information. During the first period of his life he studied with a number of teachers and remained with some of them for longer periods. ${ }^{84}$ But even during this time, which he partly devoted to his education, he did not enter into a subbalmulazama relationship with a teacher, in contrast to Abū Shāma.

Ibn Wāṣil's last decades in Hama are a second example of the significance of networks. As he composed the Mufarrij during this period it is important to discuss his appointment to the chief judgeship of the town. It was in the early 660s/1260s that Ibn Wāṣil returned to his home town and subsequently became its Shāfíite chief judge - a position, which he kept until his death in 697/1298. Appointment to important positions in Hama during the late seventh/thirteenth century was by a formal decree of the ruler of the town, which had then to be affirmed by the sultan in Egypt - in Ibn Wāṣil's case, al-Malik al-Manșūr Muhammad (d. 683/1284) and al-Malik al-Zāhir Baybars. The source-basis for this appointment is less secure than in the Aqmar case: the relevant decree of nomination has not come down to us and the circumstances of this nomination are less clear. Nevertheless, by considering his network in Hama during these years a similar picture to the Egyptian one emerges. The main difference was that now members of his family played a more prominent role.

Ibn Wāṣil's family was well situated in Hama. It was by no means one of the families able to monopolize specific posts in a town over longer periods, such as the Banū 'Alwān in Aleppo for significant parts of the seventh/thirteenth century, ${ }^{85}$ or the Banū al-Bārizī in Hama itself at the turn of the seventh/thirteenth and eighth/fourteenth centuries. ${ }^{86}$ But even so, Ibn Wāsil's father had held different posts in Hama and its surrounding towns. As chief judge of the town he wrote the oath of allegiance for the ruler's sons, and led the prayer of the notables and the ruler after 
the death of the latter's wife. ${ }^{87} \mathrm{He}$ also held teaching posts in other Syrian towns, for example, in Jerusalem and was offered the judgeship or the khatizbship in the congregational mosque of Damascus, which he refused. ${ }^{88}$

Ibn Wāṣil's maternal uncle Burhān al-Dīn Ismāềl b. Abī al-Damm belonged to the notables of the town and, together with his cousin Shihāb al-Dīn Ibrāhīm b. 'Abd Allāh b. Abī al-Damm (d. 642/1244), played a role in the deposition of the town's ruler al-Malik al-Nāṣir Dāūùd in 626/1229. More importantly this Shihāb al-Dīn was for twenty years judge of Hama from 622/1225 onwards. ${ }^{89}$ Having studied in Baghdad and taught in Cairo, Damascus, Aleppo and Hama, he was one of the key persons who introduced Ibn Wāṣil to the existing network structures. Ibn Wāṣil accompanied him in 641/1243 on a mission from the ruler of Hama to Baghdad, where they stayed two months. ${ }^{90}$

A paternal cousin of Ibn Wāṣil, Sa'd Allāh b. Sa'd Allāh b. Sālim b. Wāṣil (d. 673/1275), was during this time physician at the court of al-Malik al-Muzaffar Mahmūd in Hama. ${ }^{91}$ He was said to have held an influential position in the town. ${ }^{92}$ Finally, Ibn Wāṣil's brother was close to Mahmūd's son and successor in Hama, al-Malik al-Manșūr Muḥammad, and introduced Ibn Wāṣil to his future patron when they met in Egypt. ${ }^{93}$ It was this ruler who formally appointed Ibn Wāṣil in the 670s/1270s as chief judge of Hama.

Ibn Wāșil himself had served twice at the court of the town during the 630s/1230s and 640s/1240s. He had also been close to his patron's father al-Malik al-Muzaffar Mahmūd who had taken a great interest in his work: in 641/1243-4 he assisted 'Alam al-Dīn Qayșar (d. 649/1251) in constructing an astrolabe at the court. During his time as chief judge in Hama Ibn Wāșil enjoyed a high reputation among the town's rulers. In his youth al-Malik al-Ṣālih al-Mu'ayyad Abū al-Fidā' (d. 732/1332), the later ruler of the town, had studied geometry and poetry in Ibn Wāṣil's study circle ( balqa). ${ }^{94}$ Nevertheless, the family background is not in itself sufficient in order to explain Ibn Wāșil's nomination after a thirty-year break since any member of his family had last held the post. It is arguably the Egyptian Mamluk influence, which played a critical role. Hama increasingly feared for its autonomy as one of the last Ayyubid principalities, and was indeed effectively put under direct Mamluk rule in 698/1299.

In this context Ibn Wāṣil's Egyptian contacts might therefore have been decisive, since Ibn Wāṣil still had contacts there among the high officials at the time when he was appointed judge in Hama. An especially important contact was 'Izz al-Dīn al-Afram, Ibn Wāṣil's co-hājj, and one of the most influential persons at court. Furthermore, his Egyptian links also were of relevance in an indirect way. Ibn Wāṣil dictated his Mufarrij in Hama to the court secretary 'Alī b. 'Abd al-Rahīm Ibn Mughayzil ${ }^{95}$ who authored also its supplement. 'Alì's maternal grandfather, Sharaf al-Dīn al-Anșārī (d. 662/1264), ${ }^{96}$ had settled in the town and gained influence as the shaykh al-shuyükh. ${ }^{97} \mathrm{He}$ built strong links to the town's elite by marrying his daughters to the influential al-Mughayzil family. Members of the Mughayzil family held a series of posts in the town in the seventh/thirteenth century, among them court secretary. ${ }^{98}$ The connection between 'Alī b. 'Abd al-Raḥīm and Ibn Wāṣil is the more 
interesting as before his move to Hama Sharaf al-Dīn had been linked to Husām al-Dīn al-Hadhabān̄i via a șụbalmulāzama relationship. Thus Ibn Wāṣil, who was similarly linked to Husām al-Dīn some years later, found in Hama not only a network of family members; he was also able to draw on his associations, which he had established in the preceding decades in Egypt, and to activate a network of relatives of Sharaf al-Dīn and the linked al-Mughayzil family.

One can thus set his appointment as judge into a similar framework of network relationships as his appointment as mudarris in the Aqmar Mosque in Egypt in 644/1246. The picture emerging from both appointments shows that it was less ruler-centred than is partially implied by both the contemporary court scholar vs. ideal/withdrawn scholar dichotomy, and by modern-day secondary literature. That these scholars sought the company of the ruling elites and the patronage of rulers is beyond dispute. Nevertheless, a court scholar such as Ibn Wāșil had a much larger degree of agency to act in his social world than contemporary critics of such scholars liked to acknowledge. It was not necessary to sell oneself to a ruler, but one could attain a stable social position in the courtly world through a variety of relationships with different individuals. While a list of his institutional positions invokes a sequence of dependent and quickly changing relationships with different rulers, his social practice shows a high degree of continuity regarding links to members of the elite. This stability guaranteed a scholar's social survival beyond the patronage of specific rulers or the rise and fall of dynasties.

As a result, the description of the Mufarrij as being 'panegyric' cannot be solely assumed on the basis of Ibn Wāșil's social position. This allows us to approach his text as a considerably more complex narrative than implied in this description; the absence of unilateral relationships of dependency with his ruling patron does not necessarily exclude the possibility. However, the preceding discussion opens the field to different readings.

\section{Abū Shāma - posts, conflicts and murder}

In sharp contrast to Ibn Wāṣil, Abū Shāma ${ }^{99}$ saw himself as a representative of the 'ideal/withdrawn scholar' group. This difference can be seen when we consider the individuals with whom they formed networks. For Ibn Wāṣil the amir Husām al-Dīn al-Hadhabānī was for long periods the central person and formed a link to a network of leading administrators and military commanders in the late Ayyubid and early Mamluk period. Abū Shāma built this same relationship not with an amir, but with a scholar, his teacher 'Alam al-Dīn al-Sakhāwī (d. 643/1245). ${ }^{100}$ Abū Shāma entered into a subbalmulazzama relationship with him in 614/1217 and stayed close to him until al-Sakhāwī's death. ${ }^{101}$ The link this time was to a network of scholars, with Abū Shāma forging few significant bonds outside this group.

Abū Shāma explicitly expressed the view of himself as an 'ideal/withdrawn scholar' by sharply criticizing other scholars. He especially focused his criticism on post-holders, whom he accused, for example, of being ignorant and unjust. One of the rationales for composing his Rawdatayn was that in Damascus he attended a meeting of thirteen 
teachers, among them the chief judge of the town. While listening to them he was astonished at their ignorance of historical matters, and decided to compose a book which might help change this state of affairs. ${ }^{102}$ In addition to his disdain of other scholars for their ignorance he also especially criticized judges for their injustice. When three chief judges in Damascus, who all had the honorific title (laqab) Shams al-Dīn (Sun of the Religion), were appointed in the year 663/1265 he approvingly cites the lines composed by an anonymous poet:

The people of Damascus are doubtful with regard to the large number of judges.

They are all suns

but they [the people of Damascus] are in darkness.

and:

In Damascus a miracle appeared to the people in general:

Whenever a sun takes the judgeship the darkness intensifies!

(Abū Shāma, Dhayl, 236)

Abū Shāma not only criticized judges ${ }^{103}$ but all scholars who were, according to him, too close to the power holders. This trait was stressed by students in an insertion in the autobiographical part of his second main historical work, the Dhayl: 'He was inclined to seclusion and withdrawal. He did not wish to frequent the doors of the people of this world and thereby avoided competing for posts. ${ }^{104}$ The image of a scholar avoiding the authorities is also visible in the poem, which he composed after a first attempt to kill him. After he was asked to complain to the Damascene authorities he wrote, in answer to this request:

I said to those who asked me: 'Why do you not complain?

What happened to you is a grand injustice!'

God (may he be exalted) foreordains for us who obtains justice and whose thirst is quenched.

If we trust in him, he is sufficient!

We anticipate his reward and the blessings of the protector.

(Abū Shāma, Dhayl, 240)

This image of Abū Shāma was to be retained in the centuries to come. With few exceptions these verses were quoted in the entries on Abū Shāma in the biographical dictionaries of the eighth/fourteenth and ninth/fifteenth centuries. The entries on Ibn Wāsil, on the contrary, quoted either the verses in which he pleaded with his royal patron not to stop his payments, or verses on a young companion whose beauty he praises. 
The question arises whether Abū Shāma's criticism was aimed exclusively at holders of posts closely associated with the power holders or also aimed at offices in institutions of learning. Cook has proposed a differentiation between the former posts, which belonged to the 'black economy' (judges, censors (mubtasib) and khatī bs) and the latter posts belonging to the 'grey market' (madrasas and dār al-ḅadìths). The 'grey economy' posts were possibly less subject to criticisms, as their link with the political elite was less intimate. ${ }^{105}$ This differentiation did beyond any doubt play a role in the seventh/thirteenth century. Abū Shāma's teacher Ibn 'Asākir (d. 620/1223), for instance, refused to accept an appointment to the judgeship in Damascus, and fled the town fearing the reaction of the ruler al-Malik al-'Ádil. The infuriated ruler is then asked to consider the positive aspects of this affair: 'Praise God - may he be exalted - that in your lands and in your days somebody refuses the judgeship and chooses to flee his town out of piety and asceticism rather than accepting it. ${ }^{, 106}$ Despite Ibn 'Asākir's aversion to the office of judge, he had seemingly no objection to holding teaching positions. Even more, at one point during his career he simultaneously held the teaching appointments in three madrasas in Damascus (al-Jārūkhīya, al-'Adhrāwīya and al-Nūrīya) and one in Jerusalem (al-Nāṣirīya, where Ibn Wāṣil's father and Ibn Wāṣil himself later taught). This accumulation of posts provoked debate about the permissibility of this practice, with the eighth-/fourteenth-century biographer al-Subkī even devoting a special section to the question in his entry on Ibn 'Asākir.' ${ }^{107}$

Nevertheless, such differentiation between permissible and forbidden offices had become rare by the seventh/thirteenth century in Damascus and elsewhere. In general, those scholars in Damascus who distinguished between different degrees of permissibility, perceived continuity between permissible teaching posts in small 'clean' madrasas, fading gradually into an area of forbidden office-holding, be they in the great madrasas or judgeships. ${ }^{108}$ The distinctions between these areas was blurred as candidates for the 'black economy' positions were recruited in the 'grey market' and often continued to hold posts there; judges generally continued to hold positions in one or more madrasas. ${ }^{109}$ Even the Hanbalites, who had traditionally been the most hesitant madhhab concerning the holding of such posts, filled them indiscriminately at this point in their Baghdad stronghold, even accepting the position of the caliph's ustādh al-dār. ${ }^{110}$

By the same token, critics of the practice of holding salaried posts did tend to neglect a differentiation between a permissible and a forbidden area. Abū Shāma, for example, was opposed to holding any kind of office, and criticized contemporary post-holders for doing so. In addition to criticizing judges, he also showed disdain towards those posts financed by endowments, for example, teaching posts. ${ }^{111}$ In a poem (written in 661/1262-3), in which he defended his decision to withdraw from teaching and to work his lands, he addressed a fictive student with the words:

Do not compete and do not exceed in what you take of it [i.e. the endowment] as you know the matter!

If you are needy, take the sufficient with aversion and with the determination that it will not last a life time! 
Before us had been imams of this religion and the endowment developed [only] later.

This was not hindering the student from knowledge, so follow this tradition! [...]

Whoever is free, eschews the alms of endowments which come to him with untroubledness and ease.

What is the state of the one who abases himself in word and deed in order to receive a little? [...]

Who sells his faith for someone else's worldly treasure, indeed, the vendor of the faith will be disappointed by the loss! [...]

May God save me from competing with the people for a post [mansab]. O God [give me] endurance! ${ }^{112}$

(Abū Shāma, Dhayl, 223-4, 226)

Teachers of his, like 'Alam al-Dīn al-Sakhāwī and Ibn 'Abd al-Salām¹3 (d. 660/1262), expressed a similar mistrust of being close to the power holders in general. Abū Shāma, for example, reported a walk in a cemetery during which al-Sakhāwī showed him the verses on the grave of the scholar Kamāl al-Dīn Mawdūd b. al-Shāghūrī (d. 612/1215):

O Mawdūd! How much contains your grave of religion, virtue, piety and gentleness.

You never approached a sultan to serve him, but contented yourself with the Sultan of all sultans. ${ }^{114}$

(Abū Shāma, Dhayl, 90)

This image of the scholar withdrawn from the power holders of his time and uninterested in their wealth survived Abū Shāma's death, and not only in these writings and the poem cited here; in biographical entries on Abū Shāma it was also often stressed that he "was modest and rejected affected behaviour despite his exceeding intelligence and wide knowledge ${ }^{115}$ - characteristics associated with Ibn 'Abd al-Salām, too. ${ }^{116}$ Abū Shāma thus saw himself continuing his teacher's tradition, who was renowned for 'scorning the rulers', ${ }^{117}$ 'avoiding praising the rulers' $^{118}$ and who was said to have shamed them in public if necessary. ${ }^{119}$ Unsurprisingly, Ibn 'Abd al-Salām's stance had led to rather strained relations with power holders, which resulted in his deposition, arrest and forced exile. ${ }^{120} \mathrm{Abu}$ Shāma carefully built up the self-image of the withdrawn scholar in his writings. In his autobiographical section in the Dhayl, for example, he did not refer at all to positions he held, but preferred to underline that he passed his life in Damascus 'devoting himself to knowledge, collecting it in his writings, and issuing fatwas'. ${ }^{121}$

Despite this self-image, Abū Shāma held posts in different teaching institutions in Damascus. In 660/1262 he started to teach in the Rukniya Madrasa, and at his first lesson the chief judge and other prominent scholars were present. ${ }^{122}$ Two years later he was nominated as head of the Dār al-Hadīth al-Ashrafīya, which was the most 
prestigious post he held in his life. His first lesson there was once again attended by the chief judge Ibn Khallikān and other prominent scholars. ${ }^{123}$

In the decades before, Abū Shāma had held different posts, for instance in the 'Ádilīya Madrasa as imam. ${ }^{124}$ Although information on the exact chronology of this and other possible offices is scant, it is of interest that Abū Shāma spent large periods of his life as a resident in madrasas. For several years, at least between 634/1237 and 654/1256, he was resident in the 'Ādiliya. ${ }^{125}$ It was also in the 'Âdiliya that he composed his Rawdatayn. ${ }^{126}$ Whatever his exact positions were, at a minimum he enjoyed the privileges commensurate with the status of a resident scholar: accommodation, food and, depending on the stipulations of the waqf, possibly also clothing and other perquisites. Furthermore, his positions of the shaykh (teacher) in the Dār al-Hadīth al-Ashrafīya and imam in the 'Ādilīya were among the better-paid positions available to a religious scholar. While during the late Ayyubid period posts were generally well paid, post-holders in institutions endowed by the rulers, such as the Dār al-Hadīth al-Ashrafīya and the 'Ādilīya Madrasa, could expect even higher salaries. ${ }^{127}$ The endowment record for the Ashrafiya stated that its shaykh received 90 dirhams - that is, 9 times what was considered to be the minimum income of an unmarried scholar (measured by the income of a Quran reader). The imam in the same institution received 60 dirhams. ${ }^{128}$ This ratio was typical of the high income imams in madrasas (such as Abū Shāma in the 'Ādilīya) were receiving. ${ }^{129}$

Thus, Abū Shāma held different teaching posts, and aimed at others, some of which he could not attain. ${ }^{130}$ His discursive stance with regard to the question of working within the framework of the formalized madrasa structures differed quite clearly from the way he earned parts of his income. This difference was the more remarkable as it was not only contrary to his stated fundamental opposition to any post, but would even contradict a more differentiated opposition towards 'black economy' posts in institutions of learning specifically endowed by rulers. Although the places where he taught were not among the most prestigious institutions in Damascus, rulers of the town had endowed two of them: the 'Ādilīya Madrasa by al-Malik al-'Ādil (d. 615/1218) and the Dār al-Hadīth al-Ashrafīya by al-Malik al-Ashraf Mūsā (d. 635/1237). Arguably Abū Shāma himself was aware that his holding of posts did not harmonize with his words; for example, he declared in a poem his firm intention to relinquish his positions in the madrasas:

I have purified my soul and my honour.

I guarded this for the rest of my days, when I withdrew to my house

in word, deed and intent.

I kept my bond with the schools of jurisprudence

And I will withdraw from them

I swear it by God. ${ }^{131}$

(Abū Shāma, Dhayl, 44) 
The difference between words and deeds was similar in the case of other critics of worldly 'ālims. Abū Shāma's 'withdrawn' teacher al-Sakhāwī had even been the personal tutor to the children of the amir Mūsak, moved with him to Damascus, ${ }^{132}$ and took a teaching position there. ${ }^{133}$ Similarly, Abū Shāma did not renounce the salary he received for the positions he was appointed to, unlike some of his contemporaries. This custom was not only widespread in his time but was depicted by him as an ideal practice. ${ }^{134}$ It can also not be assumed that a possible judiciary/ education divide (with the latter being more acceptable to him), determined Abū Shāma's pattern of holding posts. In 635/1237-8 he accepted the appointment to the function of a notary witness (shähid) in Damascus by the chief judge. ${ }^{135}$

Nevertheless, Abū Shāma never held any of the most prestigious and influential positions in the town, such as a judgeship or a khațībship: he never took or received one of these important religio-political positions, in clear contrast to Ibn Wāsill's chief judgeship in Hama. As this cannot be the consequence of his explicitly stated attitude towards these kind of posts, others factors must have played a role.

Until now I have discussed Abū Shāma's social position almost exclusively in terms of his discursive position vis-à-vis the issues of posts and contacts to worldly rulers. Obviously, such a standpoint was widespread, and was one of the standard topoi of self-representation in the formative and medieval periods. It might therefore serve as an indicator, but cannot be conclusive. Consequently, these findings must be supplemented with positive 'external' evidence, which I will provide under three headings: his financial wealth, his links to the rather marginalized Maghribian exile community and his contacts with scholars as far as that is visible in ijazzas (licence to teach) and $\operatorname{sam}_{\bar{a}}$ s (certificate of attending a lecture).

Financially, Abū Shāma was part of the group of scholars who did not depend on posts (in contrast to scholars such as Ibn Wāṣil). During his lifetime this was a common feature, with twenty-eight identifiable individuals in Damascus who followed careers such as real-estate dealer, arrow-maker or perfume dealer on top of their scholarly activities. ${ }^{136}$ The land that Abū Shāma owned enabled him to live more comfortably than his positions in institutions of learning would have allowed. In the poem in which he defended his decision to work his lands rather than teach, he stated that now 'The family, relatives and followers are satiated/by it. They do not complain of poverty. ${ }^{137}$ His wealth was also manifest during the Mongol rule of the town in 658/1260, when he was thought prosperous enough for their deputy to personally demand a large sum from him, ${ }^{138}$ and at his death, when he was able to make a considerable endowment of his books. ${ }^{139}$

The pattern of the posts he held might also have been determined by the position of his family within Damascus' social structure. Unlike Ibn Wāṣil in Hama, Abū Shāma was not a descendant of a relatively prominent family within his home town. His great-grandfather Abū Bakr Ismā' $\bar{l}$ moved to Damascus after the Crusaders had killed his father, Abū Bakr Muhammad, in the conquest of Jerusalem in 492/1099. While some descendants of Abū Bakr Ismā'îl had been learned men and had even taught, it was only with Abū Shāma himself that a member of the family gained some prominence. ${ }^{140}$ There were no marriage alliances with the prominent families 
of the town such as the Banū 'Asākir or Banū al-Qalānisī. Furthermore, his family had settled in the eastern part of Damascus close to the Bāb al-Sharqī, where he himself was born. ${ }^{141}$ His house, in which he died, was to the north-east of the town, extra muros. Neither of these locations was favoured by the town's notables, who generally lived within the walls in the western part of the town. ${ }^{142}$

Both he and his family had rather close contacts with the Maghribian families, who were themselves relatively marginalized in the social texture of the town. Abu Shāma's mother, another of his father's wives, and at least one of his own wives came from Maghribian families. His daughter was married within this community, and several of his children were buried in a cemetery often used by Maghribians. These marriage connections with the Maghribian community were not the norm within Damascene society. ${ }^{143}$

Such links with the Maghribian community also found their expression in Abū Shāma's outlook. Although he belonged to the Shäfi'ite school, in contrast to the mostly Mālikite scholars from the western lands, there is a discernable Mālikite influence in his writings. His treatise against innovations ( $b_{i d a}$ ), for example, followed a genre which was mostly established by western Mālikite writers. He took over from al-Ṭuttūshī the crucial differentiation of innovations between those known to be innovations and those which are thought to be religious duties. Al-Ṭurțūshī's treatise on this subject proved to be very influential after this Mālikite author of Andalusian origin had settled in Egypt. ${ }^{144}$

Abū Shāma's social position in Damascus can also be considered in the context of his scholarly contacts. The following analysis of the ijāzas and samā's, which Abū Shāma either received or issued, is based exclusively on those preserved in manuscripts. References to students or teachers in biographical dictionaries or his own writings are excluded as they belong partly to the field of discursive self-representation. Although this problem also occurs with regard to ijāzas and $s a m \bar{a}$ 's, the fact that these are much more dispersed and were not written as a coherent text renders them a more reliable source. As far as traceable, Abū Shāma's name appeared in 8 ijāzas and samā's, of which he issued 5 and received 3 .

From these notices it appears that Abū Shāma studied and taught within groups of scholars who were rather marginal in the town's social hierarchy. Even those teachers and students well known for their learning were not connected to the great Damascene families of his period. ${ }^{145}$ Once again the number of those from a Maghribian/Andalusian background is remarkable. ${ }^{146}$ Students of his, such as 'Abd Allāh al-Jazāìīi remained limited to posts in minor madrasas. ${ }^{147}$ Others, such as the celebrated hadìth scholar Ibn Farāh al-Ishbilī, declined offers of teaching positions when they came to Damascus. ${ }^{148}$ Outstanding among his students is only the non-Maghribian and non-Mālikite scholar Yūsuf b. Muhammad al-Mișrī (d. 685/1286). ${ }^{149} \mathrm{He}$ is the only person mentioned in these notices who held a significant post in the town, being the teacher in the Dār al-Hadīth al-Nūrīya over which the Banū 'Asākir had lost their long-lasting control.

Besides these individuals, the names appearing in connection with Abū Shāma are often not traceable at all. Those who received at least an entry in the biographical 
dictionaries were dealt with briefly, for example 'Alī b. Ahmad al-Qurțubī (d. 671/1273), ${ }^{150}$ Muhammad b. Abī Bakr al-Shāghūrī (d. 676/1277) $)^{151}$ and Ismā̄êl b. Ahmad al-Mālikī (d. 680/1281), of whom it is stated that he does not bring much forth'. 152

Those who were linked to Abū Shāma by student-teacher relationships, partly give the impression of a closely-knit group. The names of his teachers - al-Sakhāwī, Ibn al-Ṣalāh (d. 643/1245) ${ }^{153}$ and Ibn 'Abd al-Salām - reappear regularly. One of Abū Shāma's study colleagues, Aḥmad al-Șiqillī (i.e. of Sicilian origin), had a long-lasting mulāzama relationship to Ibn al-Ṣalāḥ, was reader in al-Sakhāwī’s teaching circle, and married one of the latter's daughters. ${ }^{154}$ After the death of his wife he stayed a while with Abū Shāma who also finally led the funeral prayers for him. ${ }^{155}$

The most important post Abū Shāma held during his life was in a dār al-hadīth, which was not one of the fiefs of the grand Damascene families. The post-holders in the Ashrafiya were generally outsiders as opposed to the post-holders in institutions like the Dār al-Hadīth al-Nūrīya, which was controlled until the middle of the seventh/thirteenth century by the Banū 'Asākir. ${ }^{156}$ Nevertheless, the town's chief judge Ibn Khallikān attended together with other notables Abū Shāma's first session as the new post-holder. ${ }^{157}$ It was, moreover, Abū Shāma who led the funeral prayers for his predecessor Ibn al-Harastān̄, a scion of a prestigious Damascene family. ${ }^{158}$ And in the following year he led the funeral prayers for Zayn al-Dīn Khālid, the shaykh of the Dār al-Hadīth al-Nūrīya, and for 'Abd al-Rahmān Ibn Ṣașrā, who in the course of his life held several influential posts in the town's administration. ${ }^{159}$

It is remarkable that all these events, which reveal a quite different Abū Shāma, occurred within the period of one year (in 662/1264-663/1265). His post in the Ashrafiya was outstanding in comparison to his preceding modest posts. It seems that a temporary amelioration in the relationship between Abū Shāma and more influential families occurred in this period. This is supported by a consideration of the status of the sixteen individuals for whom he reportedly led the funeral prayers. ${ }^{160}$

Apart from the three individuals mentioned in the previous few lines, the other cases generally refer to rather obscure persons who were not of considerable social status. For example, in 665/1266-7, Abū Shāma led the funeral prayers on four occasions. Two were for Aḥmad b. Rị̣wān and 'Alī al-Wāṣiṭī who would both be untraceable but for Abū Shāma's references to them. The third was his friend (and son-in-law of al-Sakhāwī), Aḥmad al-Ṣiqillī. And the last was the somewhat more prominent Ishāa al-Saqațī, who had at least been deputy judge in Damascus for a short time. ${ }^{161}$

Thus, this peak of contact with socially important families was neither part of a long-standing social practice by Abū Shāma, nor something he continued. It was rather an isolated period in the life of a rather marginalized individual. A consideration of the two notable contacts with the political elite of his time reinforces this impression. The first, the amir Muzaffar al-Dīn Ibrāhīm (d. 654/1256), ${ }^{162}$ was the son of the amir 'Izz al-Dīn Aybak al-Mu'ażamī who had lost possession of his assignment of the southern Syrian town of Șarkhad in the mid-640s/1240s. Muz̧affar al-Dīn tried vainly to regain a position of importance in the entourage of al-Malik al-Ṣālị̣ Ayyūb, 
but died in Damascus without ever achieving that. ${ }^{163}$ The second was Diyä' al-Dīn Muhammad, ${ }^{164}$ who until his death in a battle against the Crusaders had been responsible for the army office (dīwān al-jaysh) of al-Malik al-Șālih in Egypt. ${ }^{165}$ In both cases it is impossible to identify the relationship more exactly.

Over and above Abū Shāma's marginalized social position, his personality also placed him outside the scholarly mainstream of his time. His strong tendency to criticize his contemporaries was discussed and scolded by other scholars. Al-Yūnīnī (d. 726/1326) wrote for example, that Abū Shāma

had a strong aversion to 'älims, grandees and virtuous people. He discredited them, mentioned their evil actions and slandered their reputation. But he himself was not beyond reproach. Consequently, the people censured him and talked about him. Because he thought highly of himself and slandered 'allims and notables, he fell in the esteem of the people. ${ }^{166}$

(al-Yūnīnī, Dhayl, II, 367-8)

It has been argued that this criticism is mainly explicable by madhhab rivalry and personal aversions between the Hanbalite al-Yūnīnī family and the Shäficite scholar Abū Shāma. ${ }^{167}$ The fact that Abū Shāma wrote a treatise against al-Yūnīnī's father, in which he accused him of some gross mistakes, ${ }^{168}$ supports this interpretation as well as the rather negative biographical entry of al-Yūnīnī's father in Abū Shāma's Dhayl. ${ }^{169}$ Nevertheless, al-Yūnīnī was not alone in his evaluation of Abū Shāma, which was taken up by a variety of authors of different denominations. The ninth-/ fifteenth-century Shāfi'ite scholar al-Sakhāwī cited the passage from al-Yūnīnī in his defence of the study of history. He placed it in a section where he defended the study of the past against those arguing that the linked personality criticism could lead to calumny. While he saw personality criticism in general as a legitimate duty in order to expose blameworthy individuals, ${ }^{170}$ he admitted that somebody like Abū Shāma belonged to those "who had trouble because they used their loose tongues without any basis or grounds of suspicion'. ${ }^{171}$ Another later scholar, the Hanafite Ibn al-Furāt (d. 807/1405) also criticized Abū Shāma for writing negatively about a scholar in his Dhayl, whereas it would have been appropriate 'to mention him only positively as he belonged to the transmitters of hadīth and the 'alims'. ${ }^{172}$ The Christian scholar Ibn al-Suqā̄i (d. 726/1326) reported that Abū Shāma was even secretly severely criticized by some of his students. ${ }^{173}$ Al-Yūnīnī's critical opinion of Abū Shāma was thus shared by a variety of authors. This is not surprising given Abū Shāma's style of attacking individuals. As mentioned, he accused judges of injustice, and teachers of dependency on endowments. In addition, in the course of a long poem he exposed judges in Damascus to ridicule for defectively pronouncing the letters $\mathrm{R}$ and $\mathrm{Q}$, and attacked them for serving the Mongols and for indulging in adultery/whoredom. ${ }^{174}$

His criticisms of eminent figures in the town went so far that later writers could claim, wrongly, that he sided with unorthodox figures such as the mystic al-Harīri (d. 645/1247), who was accused of displaying heretical ideas like ignoring the ritual prayers, slandering the prophets and endorsing apostasy. Many 'álims of the town, 
among them Abū Shāma's teacher Ibn 'Abd al-Salām, issued fatwas arguing for his execution. Al-Harīrī was imprisoned several times, and finally forced to leave the town. ${ }^{175}$ Abū Shāma criticized him severely in his Dhayl, ${ }^{176}$ which did not prevent later authors, like al-Dhahabī (d. 748/1348), from claiming that Abū Shāma had defended al-Harīin with the words: 'He followed the duty of the shari ' $a$ in its outward and inward aspects in a way unknown to anyone of the jurisprudents [mutasharri'un]. Most people err with regard to him [...]. God revealed to him the secrets of his chosen men. ${ }^{, 177}$ Contrary to the impression given by this citation, Abu Shāma vehemently argued against practices, which he perceived to be deviations, such as newly introduced prayers. ${ }^{178}$ His opposition to such prayers, which were popular and widely practiced in Damascus during his period, arguably contributed to his unpopularity in the town. ${ }^{179}$

Abū Shāma's somewhat controversial nature is thrown into relief by the cause of his death in 665/1267, at the age of sixty-six years. Abū Shāma had referred in his Dhayl to two men who had entered his house under the pretext of demanding a juridical opinion (fatwa), and had beaten him severely. Apparently nobody came to his aid $^{180}$ and he died some months later, possibly after the same two men had returned once again. The sources differ in the description of the events. Those writings nearest to his death do not refer to the murder at all, but state simply that he died on this date. ${ }^{181}$ A second group, starting with al-Dhahabī (who died sixty years after Abū Shāma) described the killing and blamed it on extreme Shiite groups from outside the town (Jabaliya), without stating any motive. ${ }^{182}$ And a third group, starting with Ibn Kathīr - about thirty years after al-Dhahabī - ascribed the murder to conflicts within the town. ${ }^{183}$ He stated that Abū Shāma had been accused of basing his juridical opinion partly on his personal judgement $\left(r a^{\prime} y\right)$, and not on the acknowledged procedures of jurisprudence. In this affair he had been seemingly defended by some of the hadith scholars. ${ }^{184}$

The request to complain to the Damascene authorities after the first attack, and Abū Shāma's above-cited poetic refusal ('I said to those who asked me: "Why do you not complain? [...]"') suggest that the motives for the attacks on him originated within the town itself. If the attackers had come from outside it is improbable that the question of whether to complain to the authorities would have played such a prominent role in his texts and in later writings on him. ${ }^{185}$ His refusal to complain to the town's authorities was probably not only an expression of his piety, but also linked to his social standing. As he was neither a member of one of the prominent families, nor well connected to the town's ruling and military elite, he would have found himself a difficult position in any open conflict with other 'álims. It was the scholar's capacity to involve rulers through intercession, which often played a decisive role in determining the outcome of a specific conflict. ${ }^{186}$

It seems rather that he, as a sharp critic of other scholars in the town, was accused of unorthodox tendencies. Besides the accusation of $r a^{\prime} y$, the improbable link between Abū Shāma and the heterodox mystic al-Harīiñ is possibly another remnant of accusations raised against him. Although he was defended by a group of scholars within the town, this support was obviously not sufficient to prevent his being killed as a 
result of his controversial positions. Such violence was not unusual in relationships between members of the town's scholarly elite. For example, competition for posts was often the cause of violent struggles between different elite households. One tactic for gaining control of a position was to accuse the post-holder of immorality or unbelief. ${ }^{187}$

The attacks against Abū Shāma were seemingly so vehement that at one point he contemplated suicide. He tells us this in his account of a blind Shäfi ite scholar in Damascus, Taqī al-Dīn 'İsā, who died by his own hand in 602/1206. After Taqī al-Dīn had accused a student of stealing his money, friends of this student convinced the wāli al-balad (the administrator of the town's security matters) that Taqī al-Dīn was someone who wrongly accused people, was a strange loner who had amassed this sum of money and was anyway not trustworthy. Aggrieved by the loss of his money and the slander he eventually hanged himself in a minaret, which Abū Shāma follows with his comment that 'a similar affair had happened to me, but God (may he be praised) held me back with his grace'. ${ }^{188}$ This story reflects the importance of the intercession of the military/administrative elite in conflicts within the town - an intercession which Abū Shāma was seemingly not able to count on after the first attack on his life.

Abū Shāma's thoughts of suicide additionally show that he was not always part of the scholarly mainstream of his time. Stating that he was tempted, even in passing, by an act considered highly sinful is rather unorthodox. Although not referred to in the Quran, a number of badīths leave no doubt that suicide was considered to be illicit, for one who takes his own life forfeits paradise and will be heavily punished in hell. Discussions among scholars turned mainly around the question of whether funeral prayers may be accorded to an individual who had killed himself. The importance of the subject in popular works can be seen as an indication that suicide was a common occurrence in formative and medieval Islamic society. Nevertheless, only an insignificant number of religious scholars in Abū Shāma's time committed suicide. ${ }^{189}$ While the small number reported might have been the result of excluding such deaths from the narratives, ${ }^{190}$ the fact that Abū Shāma included such a reflection in his writings shows even more the degree to which he was at the fringes of contemporary society.

Abū Shāma's reflection on suicide arguably alludes to another point relevant to understanding his biography: a personality which occasionally tended to such a degree of sadness and obduracy that he despaired of himself. In the introduction to a poem written to al-Sakhāwī about this in 640/1243, he complained about 'my intense sorrow and my sadness'. ${ }^{191}$ With his verses he inquired about 'a physician who could remedy this illness, somebody with insight to whom I could complain about this sickness', because he desperately needed help to know 'how the prisoner of [the soul] can be freed from his chains, how he can flee from its oppression and how he can be released'. ${ }^{192}$ While it would be impossible to pursue this point further - the only indication we have is this isolated poem - it is reasonable to state that Abū Shāma experienced periods of dejection during which he sought support. 
This dejection is complemented by another trait ascribed to Abū Shāma: the accusation cited here that 'he thought highly of himself'. It seems that at certain points his periods of low spirits changed to a tendency to regard himself as an outstanding personality who stood well above his contemporaries. Examining his writings, the accusation that 'he thought highly of himself' is not astonishing - he stated, for instance, about the year of his birth:

The year [5]99 started, which is the year of my birth. On a Saturday night in the end of the month al-Muharram meteors in the sky surged in the east and in the west, they flew like spreading locusts in the south and in the north. This has not been seen except when the Prophet [invocation] was sent and in the year 241. And in this year it was stronger. ${ }^{193}$

(Abū Shāma, Dhayl, 32)

He thereby established a link between the sending of the Prophet, the death of the founder of the Hanbalite madhhab, Ahmad b. Hanbal (d. 241/855) and his own birth. The link between the two former events had already been made occasionally, at least since the fourth/tenth century. ${ }^{194}$ Abū Shāma made the link between the year 241 and Ibn Hanbal's death only implicitly, not because of madhbab rivalry, but rather because by this period the connection had become a widely shared historical perception. ${ }^{195}$ Abū Shāma not only put himself into this succession of outstanding personalities, but also stressed that the phenomena connected to his year of birth were stronger than those in 241.

The accusation of Abū Shāma being presumptuous becomes even more understandable when considering the autobiographical section in his Dhayl. Here he included dreams and visions where he saw himself, and was seen by others, as the one quenching the thirst of the Muslims; as the mediator between the second Rightly Guided caliph 'Umar b. al-Khațāb and the Muslims (when the former reappeared in Syria in order to fight the Crusaders), ${ }^{196}$ as the tool of the Prophet in the conversion of a Christian ${ }^{197}$ and finally as the prophet of his time. ${ }^{198}$ Abū Shāma himself felt some unease in including these dreams and visions in his writings, but justified himself by citing the Quranic verse 93:11: 'And of the bounty of your Lord, speak!', and the Prophetic tradition which ascribed an outstanding place to such experiences: 'Nothing remains of prophecy other than the true dream/vision; the just man sees it or it makes itself seen by him.' ${ }^{199}$ This unease was arguably not just connected to citing dreams and interpreting them (which was widely accepted by Muslim scholars), ${ }^{200}$ but to their specific content.

In his autobiographical section of the Dhayl, Abū Shāma included an exceptionally high proportion of dreams and visions (over 50 per cent) compared with similar Arabic texts written in the formative and medieval periods. ${ }^{201} \mathrm{~A}$ number of these dreams and visions belonged to the standard repertoire reported in these texts, ${ }^{202}$ such as his mother being told during her pregnancy that he will be an outstanding scholar, ${ }^{203}$ or his contact with 'Umar b. al-Khațtāb as one of the protagonists of early Islamic history. ${ }^{204}$ 
However the claim to be like the Prophet and to be the 'prophet of his time' transgressed the limits of standard dreams and visions. Certainly, to see the Prophet and communicate with him was a common topos of Arabic dream narratives. But dream manuals - such as al-Nabulūsīs (d. 1143/1731) - show that implications of similarity with the Prophet were not accepted in important sections of the population. ${ }^{205}$ Such a self-perception by Abū Shāma arguably contributed to his marginalization in society.

Of importance here is that the inclusion of dreams and visions in formative and medieval texts fulfilled crucial legitimizing functions. ${ }^{206}$ In conflicts between different schools of law, for example, dreams were used to establish or attack the status of important figures of one's own, or another school. ${ }^{207}$ The dream's function was thereby similar to the hadìth's as a means of establishing authority. ${ }^{208}$ Abū Shāma's dreams and visions were therefore a crucial part of his attempts to cast himself as an extraordinary individual of his time. His implicit claims to be first one of the scholars able to practice $i j t i b \bar{a} d$, and second to be similar to the renewer (mujaddid) in standing, will be discussed in Chapter 4 .

The mere fact that Abū Shāma included a long autobiographical section in his Dhayl ${ }^{209}$ can be seen as an attempt to vindicate himself. Writing such a text was not in itself exceptional in the formative and medieval periods, by when there was a wellestablished autobiographical genre. ${ }^{210}$ Nevertheless, Abū Shāma's autobiography stands out from other texts of the type, which were, except in some isolated cases, generally written in the first person. ${ }^{211}$ This was also an author's preferred way of inserting explicit comments in a text, as Abū Shāma and Ibn Wāṣil did in their main chronicles. In his autobiography, however, Abū Shāma used the third person when referring to himself, which particularly contrasts with the remaining text of the Dhayl where he spoke about himself in the first person. By setting his autobiography apart from the remaining text he created a fictive distance in order to situate himself in relation to his immediate environment, the larger Muslim community and God. ${ }^{212}$ The autobiographical part offered a perspective on himself, by which he hoped to 'set the record straight'. He depicted himself in this part as the descendant of a family of notables, martyrs and religious men, a well-trained religious scholar, the instrument of God who was singled out for his achievements and the subject of otherworldly visions. Writing in the third person was arguably an attempt to offer a version of his life to be taken over by later biographers. ${ }^{213}$ This attempt obviously failed as the narrative was neither taken up by later authors, nor served as an inspiration for any entry on Abū Shāma.

\section{An individual voice?}

The autodocumentary writings ${ }^{214}$ by Abū Shāma raise a more general question: to what degree were medieval authors able or willing to raise their individual voice? The depersonalized appearance of many formative and medieval texts has led to a perception of historical writing as a genre where the writer's 'personality appears as little as possible'. ${ }^{215}$ Within this assumption of a depersonalized textuality, authors 
are generally seen as transmitters of previous historical knowledge without shaping their material in significant ways.

As seen earlier, Abū Shāma displayed in his Dhayl a high degree of self-awareness, which is most explicitly expressed by his compact autobiographical section and other autodocumentary insertions dispersed throughout the text. Scholarship on Arabic autobiography during the last decade has increasingly questioned the established assumptions that this literary form first has its origins in the Western tradition and second that it is a modern phenomenon. ${ }^{216}$ The sheer number of autobiographical texts which have been identified shows that an autobiographical genre existed in the Arabic literature from the third/ninth century onwards. This tradition was discarded in modern scholarship as it seemed either quantitatively insignificant or because it did not fit into modern concepts of autobiography. ${ }^{217}$ However, an analysis of the continuous tradition of Arabic autobiography shows that the authors expressed their thoughts, emotional reactions and awareness of their psychological development over the course of time. ${ }^{218}$

Abū Shāma, for example, regularly expressed his emotions with regard to events in his family. At the death of his mother he stated: 'In this year died my mother - may God have mercy upon her. I buried her [...] and I wish to be buried close to her.'219 When his son died twenty-three years later he wrote melancholically: 'On the last Friday of this month my son [...] Muhammad died - may God unite us in paradise. I buried him at the Ibn Zuwayzān cemetery [...]. I was his accoucheur and the one who washed him. He was eight and a half years old. ${ }^{220}$ Most outstanding in the expression of his personal life is the poem which he wrote on his wife Sitt al-'Arab; ${ }^{221}$ most of it praised her for her qualities in clichés such as being a good housewife, being pious and being humble. However, he also expressed his inclination towards her with the words:

Her like is rare among the women of our time so do not reprove me so much for loving her. ${ }^{222}$

(Abū Shāma, Dhayl, 197)

Abū Shāma expressed his emotions not only with regard to his family but also to his acquaintances:

In this year [626/1228-9] died many of our companions, acquaintances and others. Among them were seven who lived in our madrasa and a group of Mālikite jurisprudents. Among our companions who died were two who were the dearest to me and whom I met most often. One of them was Zayn al-Dīn [...] - may God have mercy upon him - who had planned with me to take up pious residence in the Hijāz. We were determined to do so when the fate of death carried him away. ${ }^{223}$

(Abū Shāma, Dhayl, 156-7)

With regard to the second friend referred to here he stated that he was my most special companion. I was close to him and liked to converse with him. In the 
moments of the most distressing sorrows, which I experienced, I met with him. ${ }^{224}$ Again the 'sorrows' appear, which allude to his state of mind in the cited poem here to al-Sakhāwi and in his confession that he had thought about suicide. All this fits modern expectations of autobiography and his autobiographical section can on its own be seen as expression of a strong self-awareness. The strong proportion of dreams and visions in this section is not the expression of a depersonalized vision of him. ${ }^{225}$ Rather it is a literary means to express a self-view supported, as shown earlier, by the authoritative voice of an outsider.

In sum, it is possible to read medieval texts as the expression of individual voices. The 'discovery' of the pre-modern Arabic autobiographical genre in the last decade has profoundly changed our perception of the author's ability or willingness to converse openly on a variety of issues. One might speak of a discursive 'room for manoeuvre' for medieval authors which was excluded previously.

The detailed study of Ibn Wāṣil's and Abū Shāma's biographies has shown that the authors of the Rawdatayn and the Mufarrij situated themselves at dissimilar points within their society. Leaving aside superficial descriptions such as that both were Shāfi'ite 'älims living in seventh-/thirteenth-century Syria, this allows the often implicit assumption of medieval historical writings' homogeneity to be questioned. However, the differences in their social worlds cannot be subsumed under the two opposed terms 'court scholar' and 'ideal/withdrawn scholar'.

With regard to Ibn Wāsil, the importance of his agency in forming the social environment has been shown. In Abū Shāma's case the issue of social agency has been of lower importance, since he never acted in proximity to courts, and never dedicated any works to rulers. In consequence, his works have not been described in modern scholarship as mere panegyrics. Rather, the main point that has emerged during the discussion of his biography is that his marginalization in the social texture of Damascus was accompanied by his willingness and ability to distinctively raise his voice. It is in the following chapter that the issue of the discursive room for manoeuvre will be further pursued. 


\section{INTELLECTUAL CONTEXTS}

A striking feature of formative and medieval perceptions of the scholarly field was the various attempts to organize the sciences ${ }^{1}$ into broad schemes of classification. Most authors who wrote on this subject either implicitly included or explicitly referred to a difference between the religious or transmitted sciences (al-'ulūm al-shar'iyalal-naqlīya), such as jurisprudence (fiqh), Quranic exegesis (tafsir $r$ ) and the knowledge of the variant readings of the Quran (qir $\left.\bar{a}^{\prime} a\right)$, and the ancient, foreign, rational or philosophical sciences ('ulūm al-awā'illal-'ajam, al-'ulūm al-qadīmal al-'aqlīyalal-bikmīya), such as medicine, logic and astronomy/astrology. ${ }^{2}$ Authors did not necessarily attach notions of licit and illicit to these two sets of disciplines. ${ }^{3}$ Rather these classifications were an attempt to organize the respective disciplines according to the different sources on which they were based.

In this chapter I will discuss Ibn Wāṣil's and Abū Shāma's positions in this intellectual world by considering their pursuits of the various sciences and their corpora. ${ }^{4}$ These two authors fit into the dominant schemes of classification as Ibn Wāṣil pursued mainly rational sciences, while Abū Shāma focused his activities on the religious sciences. The discussion of what these categorizations imply will be focused on Abū Shāma, while Ibn Wāṣil appears mainly as a comparative point of reference. The main underlying question is to what degree an immersion in the field of religious sciences was synonymous with an uncritical and transmitting approach - a question which brings the discursive room for manoeuvre into the picture. In this way, the preceding argument (the autobiographical genre shows that there were many possibilities for medieval authors to innovate upon received cultural categories) is taken up. The modern image of many medieval religious scholars as non-creative compilers of already existent information, which they merely rearranged without much originality, is closely linked to the more general idea of stagnation in the Islamic lands in this period. It is in this context that a picture has emerged which has endowed the medieval differentiation between rational and religious sciences with far-reaching connotations. While the importance of this differentiation for the medieval period is beyond doubt, the modern connotations of rational/intellectual and religious/uncritical are at least debatable. 


\section{Abū Shāma: works and disciplines}

Abū Shāma was praised by students in his teaching circle in the Umayyad Mosque in Damascus in the course of a poem with the words 'King of the virtue, nay caliph of the science of religion'. 5 This emphasis on his learning in the religious sciences is also shown by students stating that: 'He composed in the branches of the useful sciences.' 'Useful sciences' were thereby understood as those which were transmitted from the Prophet Muhammad, that is the religious sciences. ${ }^{7}$ For Abū Shāma himself this classification was of importance in his writings. He used the idea of a separation between religious and other sciences when he stated in the introduction to his main work on Quranic reading that the 'useful sciences pertaining to the $\operatorname{shar}^{\prime}{ }^{\prime}{ }^{\prime 8}$ are the supreme form of knowledge. In another work he urged the scholars of his time to pursue them and refrain from the 'harmful sciences'. 'The literary production in these useful religious sciences after the period of the Prophet Muhammad was for Abū Shāma a 'good innovation'. ${ }^{10}$ He thereby implicitly argued that the writings in the field of the rational sciences were, on the contrary, a repugnant innovation. Ironically, some minor rational scholars of the seven/thirteenth century are remembered in later writings only because of Abū Shāma's - quite dismissive - obituary notices. $^{11}$

The fact that in his last years he taught in the Dār al-Hadīth al-Ashrafīya shows that Abū Shāma belonged to the group of scholars strongly orientated towards the religious sciences. The first teacher nominated by the Dār al-Hadīth's anti-rational founder, the Damascene ruler al-Malik al-Ashraf Mūsā (d. 635/1237), ${ }^{12}$ was Ibn al-Ṣāāh, Abū Shāma's teacher who was well known for his public antipathy towards, and active stance against, the rational sciences. He issued a fatwa serving as the basis of al-Ashraf's policy towards the rational sciences:

Philosophy is the basis of foolishness and weakness [in belief], the base of confusion and error, the teaching of deviation and heresy. Whoever philosophizes, his sight becomes blind to the beauties of the $\operatorname{sharī}^{-} a$, which are supported by proofs. Whoever adopts it will be afflicted by disappointment and deprivation, the devil will take possession of him and his heart will be darkened for the prophethood of Muhammad [invocation]. [...] The use of terms pertaining to the field of logic in dealing with the rules of the $\operatorname{shar}^{-} \mathrm{a} a$ belongs to repugnant forbidden actions and invented stupidities. The rules of the shari $\bar{\imath}^{\prime} a-$ God be praised - do not require logic. [...] Thus, it is the duty of the ruler [invocation] to protect the Muslims from the evil of these sinister individuals, to expel them from the madrasas and to exile them. ${ }^{13}$

(al-Dhahabī, Ta'rīkh, years 641-50, 187)

This dominant figure of Shäficite jurisprudence in the first half of the seventh/ thirteenth century in Damascus influenced his students and successors in the Ashrafīya, Ibn al-Harastān̄̄ ${ }^{14}$ Abū Shāma and al-Nawawīi. ${ }^{15}$ All of them were famous 
for their specialization in the fields of jurisprudence and tradition, while not practising any of the sciences of the Ancients. As a representative of the non-rationalist tendency in the Shāficite law school in Damascus during the seventh/thirteenth century, Abū Shāma was out of contact with teachers having a stronger interest in the rational sciences, with the exception of the philosopher and theologian 'Alī b. Muhammad al-Āmidī (d. 631/1233). ${ }^{16}$

Abū Shāma was mostly characterized in biographical dictionaries for his knowledge relating to the non-speculative sciences of religion: Quranic reading and tradition. He practiced Quranic reading in its educational form, that is, the studying and teaching of the correct way to read (iqra $\vec{a})$, in contradistinction to the liturgical and devotional practice of reciting the Quran in mosques and tombs (qir $\left.\bar{a}^{\prime} a\right) .{ }^{17}$ For Abū Shāma, iqra $\bar{a}^{\prime}$ was the supreme discipline among all other forms of knowledge. ${ }^{18}$ Next to the Rawdatayn, it is the Ibrāz al-ma'ānì min hirz al-amān $\bar{\imath} \overline{\bar{l}}$ al-qira'āt al-sab', which made Abū Shāma's fame. This work was a commentary on the poem on Quranic reading by al-Qāsim b. Fīrruh al-Shāṭibī (d. 590/1194) who had been the dominant figure in this discipline during his time. Nearly every Quranic reader of the following generation wrote a commentary or summary on al-Shāțibī's work. Kashf al-zunūn, the eleventh-/seventeenth-century survey of manuscripts in Istanbul, alone lists eight works written in the seventh/thirteenth century, and a continuous stream of works in the following two centuries. ${ }^{19}$ The reading according to al-Shātibī was introduced to Damascus via al-Sakhāwīe, Abū Shāma’s șụ̧ba teacher, where it was especially popular within the Maghribian milieu of the town. ${ }^{20}$ This line of transmission was fitting because al-Shātibī originated from present-day Játiva in south-east Spain. He fled his home town after he had been asked to become khațīb, as he wanted 'to refrain from what the khațībs were forced to mention from the pulpits of embellishments [of a person] which he considered not to be permissible according to the $\operatorname{shari~}^{-} a^{\prime} .{ }^{21}$ Leaving a town in order to avoid a post which would have included certain forms of praising the respective ruler was an attractive act to the, at least discursively, withdrawn scholars of Damascus.

The Ibrāz and the Rawdatayn are Abū Shāma's only works to have survived in a significant number of manuscripts (around twenty). The Ibrāz was read and copied across the Islamic world from Istanbul, via Cyprus, ${ }^{22}$ Syria and Egypt, to Persia and Yemen. ${ }^{23}$ In the decades after its composition it was so popular that a professional copyist in Persia in 699/1299 made 6 copies of the first and 3 copies of the second part. ${ }^{24}$ Scholars praised it as 'valuable', 'of utmost quality' and 'famous'. ${ }^{25}$ However, the work's popularity dwindled in the following centuries. After the 13 copies of the eighth/fourteenth century, only 4 were produced in the ninth/fifteenth century and 4 in all the following centuries.

A second work by Abū Shāma on the sciences linked to the Quran, al-Murshid al-wajīz ilā' 'ulūm tata'allaqu bi-al-kitāb al-'azīz (Concise Guide to Sciences Connected to the Venerable Book), also focused mainly on Quranic readings. It was not so widely transmitted, but was indeed mainly limited to Syria. Furthermore, it was often inserted into collective manuscripts with other works on this science, ${ }^{26}$ and not copied as an independent work such as the Ibrāz. His Kitāb al-basmala on the 
pronunciation of the first süra of the Quran also enjoyed certain popularity after his death, and was praised by later authors. ${ }^{27}$ The four known manuscripts of it and its summary, which Abū Shāma composed himself, were all copied in the eighth/ fourteenth century, ${ }^{28}$ but this transmission was limited to Syria and stopped in the following centuries. A final work in this field, Mufradāt al-qurra $\bar{a}^{\prime}$ (Expressions of the Quran Readers) is mentioned in many biographical dictionaries, but has apparently not survived in manuscript form.

Abū Shāma's second main field of learning was, according to later biographers, hadīth. His last stipendiary post in the Dār al-Hadīth al-Ashrafìya was an expression of his learning in this field. Nevertheless, compared to Quranic reading, his literary output in this area was rather meagre, possibly because his interest in it started only when he was in his thirties. ${ }^{29}$ His two works, a commentary on the hadith collection by al-Bayhaqī (d. 458/1066) and a treatise on hadìths linked to the Prophet's ascension, have both been lost. Arguably, he was interested in badīth study not for its own sake, but rather as an important tool in his position on ijtibād. His interest was in general not directed towards issues linked to the transmission chains (isnāds) of the texts in order to evaluate their reliability. Rather, he focused on the study of the hadīths' texts (matns) as a primary textual source next to the Quran. This focus is particularly visible in his works on $u s \underline{u}$ l al-fiqh.

Abū Shāma composed two works of Quranic interpretation, both on the issue of the Prophet's ascension. In his Tafsīr ayat al-asrā' (Interpretation of the Ascension Verse) he argued that the prophet's ascension took place at least twice. This rather unorthodox stance attracted the attention of later authors such as al-Subkī (eighth/ fourteenth century) and Hājjjī Khalīfa (eleventh/seventeenth century), who both discussed its contents. ${ }^{30}$ In the second work, al-Wādih al-jalī fī al-radd 'alā al-Hanbali (The Elucidated and Clear Refutation of the Hanbalite), he refuted the treatise on the same subject by the Hanbalite author Muhammad b. Ahmad al-Yūnīnī (d. 658/1260). ${ }^{31}$

Final, in the category of the religious sciences, Abū Shāma composed commentaries on poems praising the Prophet Muhammad. The seventh/thirteenth century saw in Egypt and Syria an intensification of the veneration of the Prophet, evidenced by the works composed, and practices such as the veneration of the Prophet's relics in the Dār al-Hadīth al-Ashrafīya. This development was fostered by the Maghribian Muhammad b. Sa'īd al-Bușīin (d. 695/1296), ${ }^{32}$ who composed the famous poem Qașidat al-burda (Poem on the Prophet's Outer Garment), and who was the teacher of a large number of Egyptian and Syrian scholars. Abū Shāma's teacher al-Sakhāwī himself composed in this field. Abū Shāma commented on both al-Sakhāw̄̄'s poem and on a piece by Muhammad b. Yahyāa al-Shaqrāțīisì (d. 466/1074), an obscure author who is only known for this poem. Most significantly, Abū Shāma was the first of a stream of authors who commented directly or indirectly on al-Bușīin̄s work in succeeding centuries. ${ }^{33}$ The transmission of his works praising the Prophet was once again focused on the Maghribian community. For example, an ijāza, which Abū Shāma issued for his commentary on al-Sakhāwī's work stated that the reader in the fifteen sessions was 'Abd Allāh al-Jazầ'irī. ${ }^{34}$ 
Although Abū Shāma was generally described as a jurisprudent and mufti, and was also appointed as notary witness in Damascus in 635/1237-8, no traces of these activities have come down to us. Apart from two treatises in the neighbouring discipline of theoretical jurisprudence, his activities in applied jurisprudence, such as his juridical opinions (fatwas), were seemingly not deemed worthy enough to be recorded or at least transmitted.

Like most scholars, and especially the Quran readers, Abū Shāma had an interest in the auxiliary Arabic sciences. And, like many of his contemporaries, he wrote an explanation on the famous grammatical work by al-Zamakhsharī (d. 538/1144), the Mufașal. ${ }^{35}$ His second grammatical work was an explanation of the Muqaddima $f_{\bar{\imath}}$ al-naḅw (Introduction to Grammar) by Ṭāhir b. Aḥmad Ibn Bābishādh (d. 469/1077), a less renowned work. As Abū Shāma did not develop a particular interest in this field, and commented only on works which had already been commented upon previously, no manuscripts of these works are known to have survived.

Moving the scale towards the rational sciences, Abū Shāma wrote in two intermediary categories: theoretical jurisprudence (usül al-fiqh) and speculative theology (kalām). Unlike jurisprudence ( fiqh), which is concerned with practical application, theoretical jurisprudence focuses on the underlying fundamentals of Islamic law, especially the methodology of finding and discovering the rules of law. It is consequently more speculative in nature, and one regularly finds a theoretical jurisprudent simultaneously pursuing rational sciences, such as al-Āmidī, for example. ${ }^{36}$

Abū Shāma's treatise al-Muhaqqaq min 'ilm al-ușūl fìmā yata'allaqu bi-af'āl al-Ras $\bar{u} l$ (What Can Be Ascertained of Theoretical Jurisprudence with Regard to the Acts of the Prophet $)^{37}$ relied strongly on al-Āmidī's magnum opus in this field, the Kitāa al-iḅkām

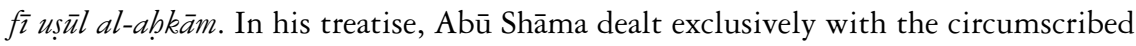
subject of the Prophet's acts, which for al-Āmidī was of rather marginal importance. ${ }^{38}$ This was one of the less speculative issues in the general curriculum of theoretical jurisprudence, compared to such topics as the discussion of the relevant theological postulates, which al-Āmidī treated in the introduction of his work. In general, Abū Shāma's works in this field did not result from an excessive interest in engaging with theoretical questions.

This can also be seen in his second treatise on theoretical jurisprudence, Mukhtasar al-mu'ammal lil-radd ilā al-amr al-awwal (Summary of what Can Be Hoped for to Restore the Original State), which basically stated the importance of having recourse to the Prophet's example and the Quran in order to form juridical opinions. ${ }^{39} \mathrm{His}$ emphasis on the importance of returning to, and keeping up, the practice of early Islam is also visible in a short treatise of his entitled $a l-B \bar{a}$ ' ith 'alā inkār al-bida' wa-al-hawādith (Inducement to Reject Innovations and Misdeeds), in which he strove to repel innovative prayers. ${ }^{40}$ This, together with his two works on theoretical jurisprudence throws an interesting light on the writings of Abū Shāma, for, as we will see, they did not wholly conform to the dominant teachings of his time.

Kalām (theology) was initially one of the religious sciences aiming at bringing discursive arguments to the service of belief. However, its use of rational arguments and its culture of arguing constantly attracted practitioners of the rational sciences. 
While kalām initially set out to confront philosophers, this led to the development of a mixed genre including both philosophy and theology. Scholars such as al-Ghazāli criticized kalām for its strong philosophical influences and declared it to be dangerous for the simple people, ${ }^{41}$ while Ibn Taymīya (d. 728/1328) expressed his outright hostility towards it. This latter stance was linked to the fact that in seventh-/thirteenthcentury Syria the term had acquired the meaning of 'speculative theology', and had become the main discipline around which the rational scholars grouped. ${ }^{42}$

Just the same, neither Abū Shāma's teachers, nor he himself, studied with any of the supporters of speculative theology in Damascus during his period. ${ }^{43}$ His writings in this field, contrary to his works on theoretical jurisprudence, did not deviate from the traditionalist teaching of his time - indeed, they show rather his aversion to the scholars of rational sciences. His Daw' al-qamar al-sārì ilā márifat al-bārì (Light of the Nocturnal Moon to the Knowledge of the Expert) dealt with the issue of God's visibility in the Hereafter. Here he argued against the Mu'tazilite rationalist point of view and emphasized that his thinking was based on 'the transmitted proofs [which] are deduced from the Quran and from the established Sunna'. ${ }^{44}$ His second kalām work al-Kurrāsa al-jāmi'a li-masā'il näfi'a (Sketchbook Assembling Useful Problems) discusses similar issues, such as the question of the Prophet's ascension or God's visibility in the Hereafter. ${ }^{45}$

Abū Shāma considered his works in the religious sciences to be sufficiently important to compose an introduction to a collection of all his relevant works. ${ }^{46}$ However, later authors rarely accepted his own evaluation, and, with one exception, transmitted his works separately. ${ }^{47}$ His remaining works on issues such as al-Siwäk wa-ma ashbaha dhäk (Cleansing the Teeth and What Resembles it) never gained longerlasting popularity, either during his lifetime or afterwards. ${ }^{48}$ His poetry, for example the poems on his wife and on his melancholic disposition, largely suffered the same fate, probably because the best said about it was that 'it is not bad'. ${ }^{4}$

\section{Abū Shāma: ijtihād, taqlīd, opposition to innovations and tajd $\bar{\imath} d$}

One of the indicators of medieval decline has been identified in modern scholarship with the 'closing of the door of $i j t i h \bar{a} d$ '. In Sunni Islam, ijtihād refers to the individual reasoning applied by jurists for finding a rule of law based on evidence essentially found in the 'Two Sources', the Quran and the Sunna. In the words of a seventh-/ thirteenth-century jurisprudent it is the 'total expenditure of effort in seeking an opinion regarding a rule of divine law such that the one [putting forth the effort] senses within himself an inability to do more [than he has done]'. ${ }^{50}$ Until the $1980 \mathrm{~s}$ it was generally assumed that the application of ijtibād in Sunni Islam had disappeared after the third/ninth century with the formation of the law schools, after which taqlid , that is the following of a legal decision taken by another jurist, gained a dominant position. ${ }^{51}$ However, in the last two decades this assumption has been challenged by a number of studies showing that ijtihād continued to be practiced in following centuries. ${ }^{52}$ Scholars have argued that although certain groups within 
Islamic societies rejected it, there was never a consensus on this issue. In the seventh/thirteenth century at least, the debate among scholars about the possibility that a period might be devoid of mujtahids was purely theoretical and did not involve arguments about the closure of the gate of ijtiba $\bar{a} .^{53}$

In recent years a middle position has emerged, which argues that ijtibäd as meaning unmediated access to the Two Sources (Quran and Sunna) did indeed largely stop. The continuation of $i j t i b \bar{a} d$ referred merely to lower degrees of $i j t i h \bar{a} d$, in the sense of interpretive thinking within the established scholarly canon. ${ }^{54}$ According to this line, the view in Abū Shāma's period emerged that the highest rank of mujtabid mustaqill (independent mujtabid)/mujtahid mutlaq (unrestricted mujtabid) had been limited to companions of the Prophet and the founders of the law schools. Mujtabids of later centuries, on the other hand, were considered able to attain only lower ranks such as mujtahid fì al-madhhab (limited to decision within one specific law school) ${ }^{55}$ Imujtabid muqayyad (restricted mujtabid). It has been shown, for example, that Abū Shāma's successor in the Dār al-Hadīth al-Ashrafīya, al-Nawaw̄ì, understood ijtihād not as the direct consultation of the Two Sources but as interpretative thinking about the law within the subsequently developed tradition. ${ }^{56}$ Thus, according to this middle position, the gate of ijtibād in its classical sense was indeed closed, while 'minor' ijtihād continued to be applied. Keeping this discussion in mind, I discuss in the following what room for manoeuvre there was in the field of religious sciences in the seventh/thirteenth century, with specific reference to ijtibād in Abū Shāma's writings.

Abū Shāma was among those individuals in the post-formative period of Islam who were described as having attained the rank of a mujtabid. ${ }^{57}$ This is rather surprising as his contribution to Islamic law (applied and theoretical) was modest. His fatwas have not come down to us, and his completed writings in applied and theoretical fiqh were limited to three treatises (the Inducement to Reject Innovations [Ba-'ith], the What Can Be Ascertained [Mubaqqaq] and the Summary of What Can Be Hoped for [Mu'ammal]). Being mujtabid, he found himself among those making decisively more important juridical contributions. For example, in the seventh/thirteenth century in Egypt and Syria these included Abū Shāma's teacher Ibn 'Abd al-Salām

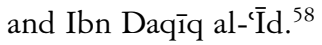

However, important differences persisted in the understandings of ijtihād among these mujtabids. In contrast to the argumentation of the present-day middle position, the main issue was still to which sources this ijtihād should mainly refer - to the writings of later authorities ('minor ijtihād'), or to the Two Sources? Abū Shāma was one of those scholars who understood the term ijtihād as a direct return to the Two Sources. Although he certainly did not advance any claims to founding a new madbhab, he refused to accept that later authorities, such as the founders of the law schools, had an all-embracing hegemonic position. He advocated a reading of the term which emphasized the need to largely disregard subsequent opinions.

In his Summary of What Can Be Hoped for to Restore the Original State he laid out his understanding of $i j t i b \bar{a} d$ in detail. He included in it, for example, a Section on the Duty of Having Recourse to the Quran and the Sunna. ${ }^{59}$ Here he argued that only by consulting 
the Two Sources could disputed matters be solved. Other sources such as ijma $\bar{a}^{c}$ (consensus of scholars) or qiyās (reasoning by analogy) rarely appeared in the text and then only with negative connotations: 'Reasoning by analogy is like the meat of an animal not slaughtered in accordance with ritual requirements - if you are in need of it, you take it.' 60

He certainly did not disregard the opinions of the school founders completely, and repeatedly referred to them in this section and elsewhere. However, he did not refer to their concrete juridical decisions, but cited them mainly to support his view that there could not be any authority besides the Two Sources. Thus, 'al-Shāfi'i forbade [his students] following himself or others [blindly]'. ${ }^{61}$ Abu Shāma weakened the authority of any statement besides the Two Sources by arguing that no individual was faultless: 'It is not allowed for anyone to use the statement of a mujtabid as an argument as the mujtahid might be correct or might err. ${ }^{62}$ No source except the Quran and the Sunna could therefore be safely consulted for guidance.

$\mathrm{He}$ attacked his contemporaries for giving preponderance to later juridical writings such as those by Ibrāhīm b. 'Alī al-Shīrāzī (d. 476/1083) and al-Ghazālī. It was this perceived acceptance of later authorities which induced Abū Shāma to compose his work, in which he hoped to restore 'the Original State.' He could only observe with disgust the factionalism $\left(t a^{6} a s ̦ u b\right)^{63}$ of the schools of law and how for their followers the statements of their imams gained [...] the status of the Two Sources [Quran and the Sunna]'. ${ }^{64}$ This was even more abhorrent as the conditions for ijtihād had become more propitious because of the spread of the hadith collections. ${ }^{65}$ Despite that, he stressed at the very beginning of this work, that those able to perform ijtibād had become few in his day. ${ }^{66}$ At the same time he severely criticized his madhbab for the doctrinal discrepancies and contradictory statements of its two 'tarīqas', the Iraqians and the Khurasanians; the adherents of these tarīqas did not even consult the works of al-Shāfici directly, never mind the Quran and Sunna, but relied on later deviating transmissions. ${ }^{67}$

A further concern for Abū Shāma was the question of which parts of the Sunna were to be considered the basis of law. His work on the Prophet's acts, the What Can Be Ascertained of Theoretical Jurisprudence with Regard to the Acts of the Prophet, has to be seen in this light. The main question discussed in theoretical jurisprudence with regard to this topic was to what degree these acts could be used as indicators of law. The positions taken in this debate also demonstrated the rigour of one's outlook: those who argued that the acts were indeed self-sufficient indicators of law enlarged the number of straightforward sources relevant to the juridical sphere. ${ }^{68}$ Such a stance limited the room for manoeuvre for later jurisprudents as the relevant examples would have been beyond discussion. Abū Shāma, together with his teacher al-Āmidī, took the opposite view and declined to consider most of the Prophet's acts as sources of law.

His teacher - and most other proponents of this position - focused his argument on demanding further indicators, such as sayings of the Prophet, so that the field of relevant acts was considerably limited. But Abū Shāma, while basically agreeing with his teacher's outlook, took a different line by accepting that the acts were 
self-sufficient without needing further indicators. He focused instead on the categorization of these acts within the traditional five juridical and moral categories (obligatory, recommended, neutral, disapproved and forbidden). By describing most acts as being 'recommended', not 'obligatory', ${ }^{69}$ he moved them from the legal to the moral field. While the category 'recommended' (as much as 'disapproved') has substantial ramifications for the soul's salvation in the hereafter, they are of little relevance to the juridical process in this world - where in turn the categories 'obligatory' and 'forbidden' are crucial. In this way he limited the number of legally binding examples and extended the field for the jurisprudents' consideration.

Abū Shāma limited himself not only to conceptualizing ijtihād in such broad terms, but applied the concomitant methodology in his writings. The Inducement to Reject Innovations was a treatise on the șalāt al-ragha'’ $i b$ (prayer of supplications), which was performed on the first Friday of the lunar month of Rajab. This prayer was similar to the prayers of mid-Sha'bān accompanied by popular festivities in Damascus. ${ }^{70}$ The special status of Rajab since the early Islamic period had probably been taken over from pre-Islamic notions of sanctity. Individuals following this custom performed practices such as sacrifices, fasting and prayer. ${ }^{71}$ The issue of șalat al-ragha $\bar{a}^{\prime} i b$ had previously caused conflicts in the town when Ibn 'Abd al-Salām attempted to stop the practice in 637/1239-40 after his nomination as khați $b$ in the Umayyad Mosque. ${ }^{72}$ The commoners succeeded in winning over the ruler of the town in their opposition to Ibn 'Abd al-Salām. Supported by a fatwa by Ibn al-Ṣalāh, who suddenly revised his earlier opinion on the matter, the prayer continued to take place. ${ }^{73}$

For Abū Shāma, the șalāt al-ragha'’ ib was only one of many reprehensible practices in his lifetime. He accused the groups of those inclined to poverty [a reference to mystical and ascetic groups] who are in reality [only] poor in their belief', of illicit relations with women, breaking rules of fasting and neglecting the prayers. These practices were, according to Abū Shāma, also the basis for pagan practices of unbelief such as idolatry. He especially deplored the veneration of specific places, such as springs, trees and stones in the belief that it might lead to recovery from illness or fulfilment of wishes. ${ }^{74}$

Abū Shāma wrote his treatise after the conflict on the salāt al-raghä'ib had taken place, and argued vehemently that the prayer was a repugnant innovation, which needed to be stopped. However, the fact that Ibn Taymìya vainly tried again some fifty years later to stop these prayers ${ }^{75}$ shows that Abu Shāma's attempts to end the practice were as unsuccessful as those of his teacher Ibn 'Abd al-Salām. Nevertheless, Abū Shāma's position in this dispute continued to be taken into account by later generations: an anonymous owner of a manuscript of his Dhayl, for example, added a folio with a badìth defending the practice of the mid-Sha'bān prayers. ${ }^{76}$

Abū Shāma's focus on the issue of innovations followed a well-established literary genre $^{77}$ which was especially common among writers of Maghribian and Andalusian origins ${ }^{78}$ belonging to the Mālikite madhbab. ${ }^{79}$ It is here that the close social interaction of Abū Shāma with these communities in Damascus found its expression in his intellectual orientation. However, he did not merely contribute to the genre itself; rather, he used it to spell out his concept of the need for continuous ijtib $\bar{a} d$. The Inducement 
to Reject Innovations showed, with regard to a number of innovations, that only recourse to the Quran and Sunna could rectify a deviation from the 'original state' of the Prophet's period. In the text he used the Two Sources almost exclusively, and largely ignored later works. The choice of innovations as a subject was appropriate, given his outlook on the status of scholars. The very endorsement of these reprehensible innovations by such respected scholars as Ibn al-Ṣalāh underlined the deficiency of any statement outside the Quran and Sunna. The disputes that arose around the permissibility of certain practices were in themselves a support for Abū Shāma's stress on the need to consult these sources and lower the authority of any later statement. Thus, the process of $i j t i b \bar{a} d$ could never come to an end as no scholar, including himself, could claim an authoritative status with regard to the Quran and Sunna. Abū Shāma was certainly in a minority position in his time; however, it shows that ijtibād in its classical sense had not come entirely to an end in later centuries. ${ }^{80}$

As in his understanding of $i j t i h \bar{a} d$, Abū Shāma adopted a wide-ranging stance with regard to the closely linked issue of taqlìd. Until recently, taqlìd had been generally equated with blind following and associated with the idea of intellectual stagnation as opposed to the more 'rational' ijtiha $\bar{d}$. However, recent work has reinterpreted the term showing especially its crucial and vital function in the medieval period ${ }^{81}$ and depicting it as 'the reasoned and highly calculated insistence on abiding by a particular authoritative legal doctrine'. ${ }^{82}$ It was only with taqli $d$ that rules derived on the basis of ijtihād could spread further, that a certain stability in the legal field developed and that the legal schools gained clear contours due to the growth of legal authority. Furthermore, scholars could not be attached to the one or other method exclusively, but were generally rather placed on the continuum between the poles ijtibād and taqlìd. A juridical argumentation based exclusively on either of the two methods would be rather inconceivable. ${ }^{83}$

Throughout Islamic legal history taqli $d$ was considered to be perfectly suitable for laymen, who could not be expected to have the necessary knowledge for individual decisions. However, within a scholarly context, the word occasionally took on a defamatory meaning when applied to other jurist-scholars. Although not every jurist-scholar was expected to be a mujtahid, the term taqlìd could indeed carry negative connotations. ${ }^{84}$ The use of the word did not criticize the fact of taking over a decision by itself, which was a normal and necessary practice, but referred to those scholars who had no insight into either the textual basis or the underlying line of reasoning. ${ }^{85}$

Despite this reinterpretation of taqlī in modern scholarship, and the ambiguity of the meaning in its contemporary context, some scholars used it nearly exclusively in their arguments, in the sense of 'blind following'. Abū Shāma, for example, delivered a sharp criticism of his period around what he perceived to be the mujtabid/muqallid dichotomy. He deplored that the scholars in his time blindly imitated their respective school founder or other outstanding figures, a practice that had arisen within the law schools over the centuries. In reference to the scholars of his time he stated, 'taqlìd has blinded him and deafened him so that he cannot hear the useful knowledge'. ${ }^{86}$ Although the actual legal practice was more complex, 
Abū Shāma perceived his contemporary scholarly community to be sharply divided into the two groups of mujtabids on the one hand, and muqallids on the other. In the post-formative period 'the mujtabids became few and the muqallids many'. ${ }^{87}$ Taqli $d$ and the importance attached to the law schools were, for him, the reasons for the deviation in his time from the 'original state' of Islam and, contrary to al-Nawawī and others, he found nothing positive associated with taqli d. He considered it rather a dangerous development where the acceptance of the respective authorities in the law schools distorted and even replaced the Two Sources; he stated that: 'A knowledgeable man was asked about the meaning of law schools. He answered that it means a substitute religion. ${ }^{88}$ At the same time, he accused those scholars who rejected the idea that mujtabids will continue to exist of being similar to the Jews who deviated from the revelation. ${ }^{89}$

Abū Shāma's polemics against the muqallids are also evident in his book on the Quranic sciences, The Concise Guide to Sciences Linked to the Venerable Book. In it, he argued against the muqallids who blindly accepted that the seven traditional readings of the Quran were all mutawatir, that is, excluding error or forgery owing to multiple chains of transmission. He questioned the authority of these readings, stating that they contained contradictions and mistakes. He cited a number of examples where grammarians had shown that certain readings were impossible. ${ }^{90}$

In doing this, Abū Shāma reaffirmed his belief in the deficiency of post-'original state' scholars. Although his opinion of the readings was widespread, the clarity with which he expressed it incurred the censure of later scholars. For example, the eighth-/fourteenth-century Quran reader al-Jamālī stated on Abū Shāma's work: 'This book has to be destroyed so that it does absolutely not appear [ever again]. It is a slandering of faith. ${ }^{.91}$ al-Jamālì's student, the great b̧adìth scholar and Quran reader Ibn al-Jazarīi, agreed with him and accused Abū Shāma of questioning the authenticity of the Quran itself. ${ }^{92}$ This view of Abū Shāma's work was seemingly not limited to these scholars: the relevant folios of this section were removed from two of the three manuscripts of this work preserved in Istanbul. ${ }^{93}$

Returning to the introductory issue of this chapter (rational versus religious/ transmitted sciences), Abū Shāma's insistence on ijtibād and his rejection of taqlīd implied an attitude, which might be called rationalist. Although he did not practice any of the medieval rational sciences, his outlook was rationalist in the sense of preferring knowledge deduced by individual reasoning from the Two Sources to knowledge transmitted from later authorities. Beyond any doubt, however, this outlook did not question the authority of the Quran and Sunna themselves - Abū Shāma never implied that the reason of man might be independent of the revelation. $\mathrm{He}$ acted within a world view where the idea that man could merely 'discover' the revealed truth and its rules was hegemonic; it was not possible to arrive at a similar truth simply by reasoning. The absence of writings on speculative theology bore witness to his refusal to extend reason to fields directly covered by the revelation. ${ }^{94}$ Consequently, he also attacked those individuals who arrogated the right to personal judgement independent from revelation and tradition. Such a line of reasoning, which he also called ijtibäd bi-al-ra'y, was reserved for a few selected men of God endowed with bukm. ${ }^{95}$ These included the Prophets David, Solomon and 
Muhammad, for example, as well as Mu'āzz b. Jabal (d. 18/639), the companion of the Prophet and outstanding scholar.

Nevertheless, within the world view of divine authority, Abū Shāma extended the scope of human reason by clearly delimiting the area of authoritative sources. His refusal to accept later authorities such as the founders of the schools of law, without further inquiry, reopened important areas for consideration. I do not intend to resurrect here the older idea of rational $i j t i \bar{a} \bar{d}$ versus blind taqlīd. However, for a marginalized scholar striving for change in his society, such as Abū Shāma, the 'positive' consequences of taqlīd (underlined by recent scholarship) had different connotations. The stability and establishment of authority perpetuated a state of affairs which he was precisely opposed to. It was only by rejecting taqli $\bar{d}$ and embracing ijtihād that he might regain discursive space.

Abū Shāma limited his intellectual activities to the religious sciences mainly because he saw the medieval rational sciences to be of minor relevance for a life in this world orientated to the hereafter. We saw earlier that Abū Shāma attacked these sciences generally not in terms of the underlying methodology, but in terms of their usefulness: they did not belong to the 'useful sciences.' These attacks were not an expression of opposition to individual reasoning by itself. Rather, the disturbing element for Abū Shāma was the often scholastic pursuit of problems, which seemed to be of no relevance in his view. It was this concept of useful knowledge versus useless knowledge which led him to attack certain practitioners of theoretical fiqh and ușul al-dīn as a group 'whose belief became the study of [these fields]' and who pass their time with scholastic subtleties of 'disputed points they [themselves] brought up and logical problems they [themselves] made up'. ${ }^{96}$

Linked to Abū Shāma's understanding of ijtihād and taqlīd was not only the issue of rationality, but also of authority. By lowering the status of preceding writings and criticizing most of his contemporary scholars, Abū Shāma expressed a claim to authority for scholars who were, according to him, able to redress the current deplorable state of affairs. ${ }^{97}$ The accusation of taqti $d$ implied an exclusion of the majority of contemporary scholars from the group qualified for guiding society.

Abū Shāma's insistence on having recourse to the Two Sources each time, and his distrust of later authorities, was closely connected to his perception of his contemporary society. One recurring theme of his writings was the decline of his period in contrast to the period of the Prophet and the Prophet's companions: 'The signs of knowledge have been wiped out. In this time its command and exact performance have become rare. This negligence led it not to be respected any more. Its honouring and glorification have become rare. ${ }^{98}$ While discussing the innovative prayers of his time, he showed how the companions of the Prophet had forbidden much lesser changes to the 'original state of affairs'. With regard to the contemporary state of affairs he could only ask with disgust:

and what would have been if the companions had seen what has been introduced of innovative prayers at reprehensible times in ways not prescribed by the revealed law? Then, fictitious hadīths have been forged in this regard 
and stubbornly defended against the people of the truth among the religious scholars who contested them. ${ }^{99}$

(Abū Shāma, Bā'ith, 71-2)

The reasons for the decline in his period were laziness among scholars and, more importantly, the love of this world. It was his discursive stance towards the issue of holding posts, which reappeared here, when he cited for example an earlier scholar, who had deplored that the scholars 'submitted their knowledge to the rulers and the people of this world, who oppressed them and scorned them'. ${ }^{100}$ This conjuncture of criticism against holders of posts and muqallids also found expression in the similar words used to attack them. While he described the muqallids as blind and deaf to useful knowledge (as mentioned earlier), he stated in his long poem justifying his 'withdrawal' to work his fields that 'the love of this world makes blind and deaf'. ${ }^{101}$ The deplorable state of his present was consequently owing to scholars who preferred to pursue worldly ends and neglected thereby the pursuit of the real knowledge, in contrast to Abū Shāma:

I chose to withdraw and be independent on my own.

I do not go to [him] who my endanger my standing

due to this world. To go to him distracts from knowledge.

Rather [I go] to a knowledgeable man or master with an outstanding reputation

in religion, who is visited for the sake of knowledge and piety, not pride. ${ }^{102}$

(Abū Shāma, Dhayl, 43)

It is here that Abū Shāma's understanding of $i j t i h \bar{a} d$ and taqlìd was crucial regarding the question of authority. He could not only represent these scholars as being too biased in favour of worldly favours, but could also question their authority in general by undermining their right to express opinions on legal matters. He did this by repeatedly citing a badìth that the Prophet feared most for his community from wrongly guided imams. ${ }^{103}$

One of Abū Shāma's hopes of redressing the current situation was that a renewer/mujaddid would once again appear and restore the 'original state'. ${ }^{104} \mathrm{He}$ referred to the Prophet's hadith that at the beginning of each century God would send someone to renew the religion of that century, and deplored that, in his age, when the mujtabids were few and the muqallids many, this hadith was met with unbelief. ${ }^{105}$ The idea of a renewer for every century to redress the state of affairs enjoyed wide currency in Islamic thought. The term became associated with the linked concepts of ijtibād and bid' $a$, but without being systematically discussed. ${ }^{106}$ The link to ijtibād was crucial as only a mujtabid, with his independent reasoning, could rectify the 
course of events. ${ }^{107}$ Ibn Daqī al-'I Id, for example, was thus seen as the mujtahid/mujaddid of the eighth/fourteenth century. ${ }^{108}$

Mujaddid was not a title bestowed upon an individual by the consensus of scholars, but was usually either claimed by the individual himself, or attached to him by the limited group of his students. ${ }^{109}$ The Egyptian scholar al-Suyūṭ̄ (d. 911/1505), for example, claimed in the ninth/fifteenth century to be both a mujtabid and the mujaddid. Together with his attacks on his contemporaries as being blind muqallids and the casting of himself as the only true scholar of his age these claims made him arguably the most controversial figure of his time. ${ }^{110}$

Abū Shāma could not claim the role of a mujaddid because he could not reasonably expect to live beyond the start of the next century, which had become the fundamental condition for such a claim. However, several issues in his writings raise the question of whether he alluded to his being a potential mujaddid. These issues included the link that he established between the lack of mujtabids and the absence of a renewer, combined with his own claim for $i j t i b \bar{a} d$. At the same time he presented himself as an outstanding scholar, not to be compared with his contemporaries. For example, when his hair turned grey at the age of twenty-five he perceived this as an auspicious sign and stated:

God illuminated his face and heart, truly he embodied guidance for those unsure of truth.

A shaykh in the true meaning, greyness came early to him, dignifying him above his fellow youths. ${ }^{111}$

(Abū Shāma, Dhayl, 38)

This perception of himself was also reflected in his brother's dream, which Abū Shāma included in his autobiographical passage. His brother saw him holding to a rope descending from heaven. Upon inquiring he was told that Abū Shāma had received the different forms of knowledge in such an abundance that it was equal to what Solomon received of material things. ${ }^{112}$ More importantly, Abū Shāma recounted the previously discussed dreams in which he entered into direct contact with figures of early Islamic history while staying in his contemporary context and portraying himself as the prophet of his time. ${ }^{113}$ Through the medium of these somewhat unorthodox dreams he claimed a close spiritual interaction with the early state of affairs which ought to be reinstated and an outstanding role for himself in the present.

This belief in his outstanding position and the self-confidence with which he attacked his contemporaries recall the later role of the mujtahid/mujaddid al-Suyūṭi in the Egyptian context who also composed an autobiography in which he claimed an outstanding position. ${ }^{114}$ Although Abū Shāma never achieved comparable importance to al-Suyūṭ̂, he gained a remarkably controversial position at least in the context of Damascus.

Abū Shāma disdained scholars who submitted to the people of this world, blindly followed the opinions of other scholars and whose knowledge was mediocre - all of 
which made them unable to understand crucial works. For example, in his introduction to the commentary on the qașìda on Quranic reading by al-Shāțibī he claimed (via a dream) that because of divine inspiration he possessed blessing and excellence that allowed him to understand the work better than any contemporary. ${ }^{115}$ Consequently, he lashed out at a Damascene contemporary who commented on the same work as having 'plunged into a sea in which he could not swim'. ${ }^{116}$

Abū Shāma's strong emphasis on the importance of $i j t i b \bar{a} d$ is one of the various explanations for the conflict leading to his violent death. The accusation that he used $r a^{\prime} y$ in his juridical procedure meant that he was partly perceived to have transgressed the acceptable limits of $i j t i h \bar{a} d$ of his period. Considering the different interpretations of $i j t i b \bar{a} d$ at this time, the accusation possibly referred to the contentious issues of sources. Abū Shāma's discussion of legal points by disregarding later authorities and focusing on the Two Sources was beyond hegemonic contemporary norms.

This is demonstrated by the fact that the historian Ibn Kathīr (d. 774/1373), the author who mentioned $r a^{\prime} y$ as a reason for Abū Shāma's death, did not belong to the established mainstream of his period in Damascus. Being a student and follower of Ibn Taymīya, he, too, rejected the idea that the practice of $i j t i b \bar{a} d$ had come to an end. Although he experienced a less troubled career than his teacher, Ibn Kathīr's only modest success in a rather hostile environment might be linked to his admiration of this controversial figure. ${ }^{117}$ The fact that he brought up the issue of accepted lines of reasoning with regard to Abū Shāma's death shows the proximity of individuals sharing a similar attitude to the issue of $i j t i \bar{a} \bar{d} .{ }^{118}$

Significantly, Abū Shāma himself rejected $r a^{\prime} y$ strongly, putting it forth as another reason for erring belief, but he understood the term differently from his critics. $\mathrm{He}$ agreed with his adversaries' reading of it insofar as it embraced the accusation of disregarding the Quran and Sunna. However, for him the central issue was not the expression of personal opinion, but the use of texts unrelated to the Two Sources and distorted owing to their later nature. ${ }^{119} \mathrm{He}$ approvingly cited in his section on $r a^{\prime} y$ the first-/seventh-century saying 'If you receive a report from the companions of Muhammad, then venerate it (lit.: put it on your head), if you receive one from the following generation, strike with it the back of their heads. ${ }^{120}$

Given Abū Shāma's understanding of ijtihād and taqlīd, as well as his critical opinion of his contemporary society, it is not surprising that his name reappeared in the writings of like-minded individuals several centuries later - the revivalists of the eighteenth and nineteenth centuries. ${ }^{121}$ The North-African Muhammad b. 'Alī al-Sanūsī (d. 1276/1859) referred, for example, to previous mujtahids in his main work on $i j t i b \bar{a} d,{ }^{122}$ among them ten mujtabids from seventh-/thirteenth- and eighth-/ fourteenth-century Damascus and Cairo who belonged mostly to the Shäficite school. ${ }^{123}$ The list began with Abū Shāma's teacher Ibn 'Abd al-Salām, and also included the latter's students Ibn Daqī al-'Īd and Abū Shāma himself. Interestingly, in one of the works of the Yemeni revivalist Muhammad b. 'Alī al-Shawkānī (d. 1250/1834) is a similar list of mujtabids outside his local setting. Starting with Ibn 'Abd al-Salām, he constructed a continuity of mujtabids stretching from the seventh/thirteenth century via Ibn Daqī al-'Īd to the tenth/sixteenth century ending 
with al-Suyūṭ̂. ${ }^{124}$ Ibn 'Abd al-Salām is also repeatedly named in the writings of Shāh Walī Allāh (d. 1180/1766) on the South Asian subcontinent in which he tried to prove a continuous $i j t i b \bar{a} d$ tradition up to his present day. ${ }^{125}$

Thus, Abū Shāma was part of this Shāficite line of mujtabids, which centred on Damascus and Egypt and which went back to his teacher Ibn 'Abd al-Salām. Abū Shāma's position regarding the issue of $i j t i h \bar{a} d$ might also be termed 'revivalist', since he formulated his critique of the contemporary state of affairs in terms of the return to an idealized early Islamic period. Like the Hanbalite Ibn Taymīya, who lived several decades later, Abū Shāma's opinions brought him into conflict with important groups in the town, such as the commoners and the more conservative religious scholars. Abū Shāma's career was less troubled than Ibn Taymīya's only because he did not tend to activism in order to implement his convictions. Nevertheless, his problems and his marginalization in Damascus, which culminated in his violent death, show that revivalist individuals were not able to impose their world view during this period. Abū Shāma's revivalist stance took perceived deviations from the 'original' state of affairs as an obvious target. It was in this field that a revivalist could clearly formulate the dichotomous notion of a complete break between the past and the present - an issue that resonated strongly in Abū Shāma's Rawdatayn as will be shown in Chapters 5 and 6.

\section{Ibn Wāṣil: works and disciplines}

Unlike Abū Shāma, the information available on Ibn Wāșil is much more limited. This is basically owing to the fact that he never wrote anything comparable to Abū Shāma's autobiography, and did not include autodocumentary passages of similar number and nature in his texts. In Chapter 3 this problem was partially solved by an analysis of his social context on the basis of his networks. In this chapter, however, the problem is more accentuated, as only very few of his works have come down to us; and these works, excepting those dealing with history, do not treat socially related issues. Abū Shāma's works, such as those on jurisprudence, dealt on a normative basis with the question of how human behaviour could be evaluated based on revealed authority. This, and his other works, allowed a certain understanding of Abū Shāma's vision of himself and of his surrounding society. Ibn Wāṣil's works, on the other hand, were concerned with 'natural' aspects such as logic and astronomy, which give us less insight into his own social vision. However, this focus is in itself informative about Ibn Wāșil's intellectual concerns. Certainly an argumentum ex silentio should not be taken too far, but taking into account his social context, and the historical outlook offered in the Mufarrij, it might be argued that Ibn Wāșil had simply little to say about a social world that did not pose any substantial problems to him.

Although he was trained in the religious sciences and held positions as mudarris and $q \bar{a} d \bar{\imath}$, Ibn Wāșil's fame rested on his learning in fields such as logic, in which 'he rose like the sun'. ${ }^{126}$ This is shown in later anecdotes, which refer, for example, to the time Ibn Wāṣil was staying at the court of the Staufer ruler Manfred in southern 
Italy in the period after 659/1261. At his request, Ibn Wāsil composed a treatise on logic, upon which the ruler supposedly praised him with the words:

O my judge! We did not ask you about the allowed and forbidden in your religion in which you are judge. Rather we asked you about things, which were only known to the ancient philosophers. You answered them although you had no books or other material with you, which you could consult. ${ }^{127}$

(al-Ṣafadīi, A'yān, IV, 1661)

Activities in religious fields were scarcely noticed by his biographers. An isolated reference to $\mathrm{fiqh}^{128}$ some references to hadīth and his activities as mufti, pale in comparison with constant references to logic.

Ibn Wāsil pursued his interest in the rational sciences mainly in al-Karak ${ }^{129}$ and Hama, ${ }^{130}$ the two places renowned for the pursuit of these disciplines during his lifetime in the Syrian/Egyptian context. The rulers' patronage there was certainly not confined to scholars of the rational sciences, but also extended to scholars of the religious sciences. However, compared with larger towns such as Damascus or Aleppo, the rational sciences were able to gain a strong profile in these minor places due to the number of relatively important scholars of the rational sciences assembled there. These scholars were arguably attracted because of their rather limited opportunities to gain an appropriate and stable standing in more important towns. The ambivalent position of the rational sciences could lead to accusations of incomplete or non-existing belief, and potentially to the prevention of teaching in one's fields. These scholars were consequently willing to accept relatively secure positions in places which would normally not have been appropriate to their standing. Major scholars in the field of religious sciences, however, turned down such offers of patronage. When al-Malik al-Nāșir of al-Karak asked the renowned religious scholar Ibn 'Abd al-Salām to join him at his court after the latter's forced exile from Damascus, the scholar refused somewhat indignantly, saying 'Your lands are too small for my knowledge', and moved on to Egypt. ${ }^{131}$

Al-Nāșir had already created a receptive climate for rational sciences in Damascus during his short rule between 624/1227 and 626/1229. The ruler had held sessions, which as well as al-Āmidī, included such scholars as al-Khusrūshāhī who was renowned for his learning in both religious and rational sciences. ${ }^{132}$ After his ousting from Damascus, al-Nāṣir continued this openness towards scholars of different branches of knowledge at his court in al-Karak. In addition to al-Khusrūshāhī, other scholars engaged in the study of the rational sciences, such as al-Ișfahān̄i, spent short spells at al-Karak. ${ }^{133}$ At the ruler's invitation, Ibn Wāṣil also spent several years at court during the late 620s-early 630s/first half of 1230s, during which time he studied the 'theoretical sciences' with scholars such as al-Khusrūshāhī. ${ }^{134}$

In contrast to al-Karak, Hama continuously attracted scholars of the rational sciences throughout the seventh/thirteenth century. It was during the rule of al-Malik al-Manșūr Muhammad (d. 617/1221) that Hama became a centre for learning where 
supposedly 200 scholars of the different disciplines found patronage. ${ }^{135}$ Al-Āmidī, for example, served the ruler after his flight from Egypt, received a regular stipend and was held in esteem. ${ }^{136}$ The ruler's son (and Ibn Wāṣil's patron) al-Malik al-Manșūr Muhammad Taqī al-Dīn (d. 638/1284) continued this tradition, for example by attracting the Egyptian astronomer and mathematician 'Alam al-Dīn to his court. 'Alam al-Dīn was a scholar of outstanding fame whom the Egyptian ruler al-Malik al-Kāmil had asked to respond to Frederick II's questions on mathematics and natural sciences. In his later years in Hama he was appointed to a teaching post there, and did sophisticated construction works for the ruler. ${ }^{137}$ When Ibn Wạșil moved back to his home town during these years he consequently encountered an environment hospitable to the pursuit of his interest in rational sciences. In 641/1243-4 he assisted 'Alam al-Dīn in constructing an astrolabe, in which the ruler took a close interest.

And this hospitality endured during Ibn Wāșil's last decades in Hama. While he was a judge, he continued to teach, and had in his teaching circle regular discussions with scholars such as the logician al-Qazwīni. ${ }^{138}$ Among his students was the later ruler of Hama, al-Malik al-Șālih al-Mu’ayyad Abū al-Fidā' (d. 732/1332), to whom he taught geometry, among other subjects. ${ }^{139}$

Owing to his interest in rational sciences, Ibn Wāșil composed a total of four works on logic - a number only equalled by his historical works. Two of them were commentaries on treatises by his teacher al-Khūnajī who was the most outstanding scholar of the rational sciences in Egypt during his lifetime. ${ }^{140}$ His commentary on al-Khūnajī's al-Jumal fì al-manțiq (The Sum of Logic), proved to be Ibn Wāṣil's most popular work in the field, with 4 copies surviving - of which 3 were produced either during his lifetime or the following 50 years. ${ }^{141}$ Ibn Wāsil's work was popular because he was the first of numerous commentators to treat al-Khūnajī's original. ${ }^{142}$ Ibn Wāșil's only other surviving work on logic is the treatise, which he wrote originally for the Staufer ruler in southern Italy and which he later reworked under the title Nukbbat al-fikar fì al-mantiq (The Pick of Reflection on Logic). ${ }^{143}$ In its reworked version it was in fact also a commentary on al-Khūnajī's Sum of Logic, and the only note on the manuscript bears witness to its low popularity. ${ }^{144}$

Although Ibn Wāṣil's contributions to the field were not especially significant, ${ }^{145}$ they earned him the hostility of later writers. Ibn Taymìya, for example, described him in his treatise against logic as a 'leading philosopher'. ${ }^{146}$ Ibn Wāsil was in the tradition of the Western school of logic, as it had developed in the preceding century. ${ }^{147}$ The leading figure in the development of this school had been Fakhr al-Dīn al-Rāzī (d. 606/1209) who had himself taught several of Ibn Wāṣil's teachers. ${ }^{148}$

The indirect influence of al-Rāzi on Ibn Wāṣil was not limited to the field of logic. Ibn Wāsil's only work close to the field of the religious sciences was also a summary of a work by al-Rāzī: Mukhtașar al-arba'in fì ușull al-dīn (The Summary of [the] Forty [Questions] on the Bases of Religion). ${ }^{149}$ The summary was not widely popular, and no manuscript of it has apparently survived. However, it is significant that his only work dealing with problems related to religious questions in a narrow sense dealt with issues of speculative theology (kalām). 
Al-Rāzi dealt with forty theological problems in his work, organized in the tradition of the arba' $\bar{u} n$ genre. ${ }^{150}$ These problems included such points as the attributes of God, in which he followed a traditional line by arguing that God is all-powerful, all-knowledgeable, living, visible and so on. ${ }^{151}$ This work reflected al-Rāzī's outstanding position in his time as a writer on kalam, and as one of the key figures in incorporating philosophical conceptions and methods into speculative theology.

Finally, Ibn Wāṣil retained certain renown for his work on poetry. He summarized the fourth-/tenth-century work Kitāb al-aghānin, which contained songs performed at various rulers' courts. In the preface to his summary, entitled Tajrīd al-Aghānī, he stated that he had undertaken the work at the request of the ruler of Hama, al-Malik al-Manșūr. The work enjoyed a limited local popularity, ${ }^{152}$ but a later copyist - who served as imam in a mosque in Hama - expressed his distance from the text with occasional comments in the margins. ${ }^{153}$ His second work on poetry was a commentary on a work on metrics by his teacher Ibn al-Hajjib: it was the first of a series of commentaries and summaries, which were produced in the following century. ${ }^{154} \mathrm{Ibn}$ Wāṣil's remaining writings on astronomy and medicine were also not very popular, and have not survived in manuscript form. ${ }^{155}$

The picture does not really change when we look at his teachers: Although he studied hadīth ${ }^{156}$ or law, ${ }^{157}$ he had more teachers in areas such as logic (al-Khūnajī) or mathematics (al-Khusrūshāhī) and he devoted more space to them in his writings. For example, he praised al-Āmidī as 'a sublime master who had precedence in the disciplines of speculative theology, theoretical jurisprudence, logic and all philosophical disciplines'. ${ }^{158}$

His interest in rational sciences led also, in contrast to Abū Shāma's case, to contacts with followers of other religions or sects within Islam. In his discussion of the Fatimid creed Ibn Wāșil was able to rely on information provided to him by personal acquaintances among followers of the sect. ${ }^{159}$ Similarly, he personally knew the leader of the Ismailis in Syria, in the late 630s/1230s. He described the relationship between him and this leader, who had come from the spiritual Ismailite centre in Alamūt (northern Persia), as friendship. ${ }^{160}$ Ibn Wāṣil had apparently no reservations about friendship with the leader of (from a Sunni perspective) a heretical sect. ${ }^{161}$ He thereby confirmed the accusations against scholars of the rational sciences of establishing close contacts with followers of such groups/religions.

In general, Ibn Wāṣil never achieved fame for his learning, as Abū Shāma did; indeed, his appearance in anecdotes stressed his limits in comparison with other scholars. One story recalls an evening of discussion in Egypt between Ibn Wāṣil and his teacher Ibn al-Nafīs. While they passed from one subject to another Ibn al-Nafīs

conversed with self-control and without becoming heated, whereas [Ibn Wāṣil] became excited, his voice grew loud, his eyes went red, and the veins of his neck swelled. When they came to an end [Ibn Wāșil] said: 'O Master [...] I know of problems and subtleties and rules, but you possess treasures of learning. ${ }^{, 162}$

(Meyerhof/Schacht (1968), 14-15) 
Later authors questioned his learning in areas like geometry. An Ottoman writer described him in his work on a sixth-/twelfth-century treatise on Euclid as those who proposed a solution 'of which a clear mind would understand its deficiency'. ${ }^{163}$

Just as Ibn Wāṣil and Abū Shāma differed in their social contexts (as we saw in the preceding chapter), so an examination of their scholarly pursuits shows them as strongly differing individuals. Ibn Wāșil focused on the rational sciences, and, as far as we can tell from his writings, he did not reflect on his position within the contemporary world of learning. Just as he was in a non-conflicting position in his social context, so he was not engaged in polemics in his intellectual context.

Abū Shāma, by contrast, worked exclusively in the field of religious knowledge, and eschewed the rational sciences. However, he was not a scholar who simply accepted the transmitted body of knowledge by reason of its authoritative quality of being transmitted. Rather, he embraced a far-reaching definition of ijtibād, which was not commonly accepted in his time. His vision of the contemporary world was characterized by a revivalist yearning for the reinstallation of an older ideal state and a disdain for the actual state of affairs. It was therefore - paradoxically? - in the field of religious sciences that this scholar could develop an outlook which was opposed to the traditionalist vision of society. 


\title{
TEXTUAL AGENCY I
}

\author{
Titles, final sections and historicization
}

The question arises of why there were so many chronicles on the reigns of Nūr al-Dīn and Șalāh al-Dīn written during the late sixth/twelfth and seventh/thirteenth centuries. Obviously the statement that ' $[t]$ here was not much need for any two annalistic works written at the same time and in the same region' ${ }^{1}$ does not apply to Syria and al-Jazīra in this period. Limiting one's interest to the factual value of the works, one wonders indeed what induced the authors to compose works which consisted mostly of passages from their predecessors. For the period up to the death of Șalāh al-Dīn (about one third of the entire work) Ibn Wāṣil's Mufarrij constituted a synthesis of previous texts, which added hardly any new information. This was especially so as Abū Shāma's Rawdatayn had already presented a synthesis of the main relevant authoritative texts for the period, including a simplification of the ornate and difficult rhymed prose (saj $)$ of 'Imād al-Dīn al-Iṣfahānī. Abū Shāma's work could be summarily described as a synthesis of existing texts, with the occasional addition based either on his personal knowledge or the odd commentary.

Nevertheless, in modern scholarship the question has been sidelined by the view that the texts are valuable for the reconstruction of contemporary events. ${ }^{2}$ This view is based on the evaluation - especially with regard to Abū Shāma - that the authors included information from previous texts which would otherwise have been lost, or that they presented known material in a more accessible form. In Ibn Wāṣil's case this evaluation is reinforced by the fact that he dealt also with his own time. While these texts' value as mines of facts has been firmly established, they have hardly been read as entities to be understood as such. ${ }^{3}$ The main exception to this tendency has been the detection of dynastic biases in favour of the Ayyubids in the case of Ibn Wāṣil, and general references to Abū Shāma's work as glorifying both Nūr al-Dīn and Șalāh al-Dīn. ${ }^{4}$

However, the multitude of historical texts dealing with the same events is an interesting point of entry for replacing fact-focused interest in these texts with a more varied approach. ${ }^{5}$ The fact that lengthy passages in these works did not add any new information invites us to consider them from different perspectives. The main concern in the following is to show that these texts can also be read as commentaries on their present societies. The discussion will demonstrate how the authors succeeded in working out specific versions of the past by using different literary strategies. 
This is not to claim that the commentary role of the works was the exclusive reason for their composition - other factors, such as the factual interests and dynastic biases named earlier did indeed play a role. The authors' wish to display their literary skills, ${ }^{6}$ and the standard argument that the writing of history was seen as a pious deed, could be added.

However, as these issues have been dealt with at relative length in secondary literature, the focus here is on the question of how the authors developed their peculiar versions of the chronicles (which were factually quite similar) so that they could serve as commentaries on their contemporary societies. In the following it will be shown that the authors claimed considerable textual room for manoeuvre by opting for a specific mode of emplotment. The concept of 'mode of emplotment' is here broadly understood in the sense of $\mathrm{H}$. White's application of the term in his study of nineteenth-century European historical writing. ${ }^{7}$ It is the kind of story into which the sequence of details (the 'raw material') is fashioned providing in this way the meaning of the narrative ${ }^{8}$ that is, the mode is essential for ordering the initially disparate factual material, structuring it in a plot and endowing it with meaning.

White defined four modes of emplotment, Romance, Satire, Comedy and Tragedy, for the works he discussed. While the general concept of emplotment is helpful for this study, the specific modes cannot be used in our context, since they are not universal modes, but closely linked to specific circumstances: they render the past intelligible for an audience only within specific temporal and cultural contexts. ${ }^{9}$

'Stasis' and 'Process', the two modes defined for the following analysis, have been established deductively from the texts under consideration. Nevertheless, these two terms are obviously not 'indigenous' terms. The concept of modes of emplotment in general is - as much as the concept of networks used in Chapter 3 - a modern approach applied to render the past readable. For the concept of networks it was possible to identify a contemporary terminology (especially șubbalmulāzama) describing the social bonds between individuals. But with regard to the modes of emplotment, such contemporary terminology did not exist. This lack is quite a common occurrence in the field of literary studies. ${ }^{10}$ The modes of emplotment are thus not given Arabic terms, which could imply that they were current in the seventh/thirteenth century. In contrast to White, I do not imply that these modes were the exclusive ones in the period under consideration, nor do I advance any hypotheses concerning their relative importance. These issues would require further detailed studies of historical works and their authors; such microstudies would probably allow for identifying a greater number of modes of emplotment for Arabic historical narratives.

Abū Shāma emplotted his narrative in the mode of Stasis. 'Stasis' is understood here in the sense of 'a state of motionless or unchanging equilibrium' as it came to be employed in twentieth-century English. In this sense Abū Shāma represented his material as the re-enactment of an ahistorical pattern, which constantly reproduced itself. Change occurs in this mode only as a sudden transition between clearly opposed periods of good and evil. Within each period, however, the notion of a gradual development is largely absent: the historical field surveyed was static, homogeneous and constantly reiterating its invariability. 
Abū Shāma's main concern in choosing the mode of Stasis was to present the two reigns of Nūr al-Dīn and Șalāh al-Dīn in a revivalist light, as a brief re-enactment of the early Islamic period. Once this exemplary period started, the narrative followed closely circumscribed lines, and invoked the impression of a 'circular' text. ${ }^{11}$ With the end of Șalāh al-Dīn's reign the pattern reverted to a period of darkness, which had been previously ended by Nūr al-Dīn's rule. For the author the pre-Nūr al-Dīn period, as well as the post-Ṣalāh al-Dīn period (i.e. Abū Shāma's present), was a period of deviation scarcely worthy of mention in his Rawdatayn.

Ibn Wāṣil chose the opposed mode of 'Process', underlining the element of unceasing development in the material. The historical field he surveyed was in constant flux, and the notion of clear-cut breaks characteristic of Abū Shāma were alien to his narrative. In contrast to Abū Shāma's circularity, his material was emplotted in a form of factual linearity. He was not concerned with the fundamental issues brought forward by Abū Shāma, but assumed that good rule was a constant reality in his narrative. His work focused on the dynasty of the Ayyubids but did not ascribe an outstanding place to them. This dynasty was merely a further example that ideal rule had existed in the past, existed in his present and would exist in the future. The choice of the term 'process' should not therefore imply any notion of a linear development towards better rule. Rather, the notion of development inherent in this term is only limited to the factual events. In 'moral' terms - that is, with regard to the issue of good rule - his narrative did not recognize any major developments. It is precisely the ongoing existence of good rule with slight variations, which formed the underlying message of his chronicle.

The analysis of the modes of emplotment in this study is not an end in itself. They are, in fact, key to understanding the meaning of the texts as intended by the authors, who focused here mainly on the issue of ideal rule. Historical writings formed a crucial issue for debating this issue - not as an abstract dispute over the merits or demerits of past periods, but as a present issue enacted via the past. By writing history, different readings of the present were brought into a more authoritative format.

This presentist role is here not understood as a mere detection of biases: for that purpose it would have sufficed merely to focus on the findings in Chapter 3 on the authors' social contexts and to present the texts as unproblematic (at most biased) reflections of 'interests'. The following analysis instead aims at introducing a further, and decisive, level into the relationship between the author and the past he presented in his text: narrativity.

The presentist concern can best be understood by examining the modes of emplotment, as it was on this level that the authors endowed the raw material with meaning. This meaning can only be a function of a perspective in hindsight because the mode of emplotment had not itself been inherent in the past. When the events themselves had occurred they were still isolated and detached instances, independent of the presentist mode to be imposed. It is only with this imposition of the mode that an active mediation between the fragments of the past (which the author is aware of) and the coherent final text (intended for the present) could take place. 
The following discussion will show first that the works' titles were of crucial importance in announcing the text's mode of emplotment to the readership. Second, it will exemplify the authors' narrative strategies by considering the closures of their texts and the types of historicization employed in them. Chapter 6 examines the issue by discussing specific scenes, which show how the authors applied additional literary means to construct their narratives. In the course of the following two chapters the texts will be generally read in a comparative perspective in order to work out the differences between two outwardly similar works. When referring to one work in the text, the footnotes will indicate whether the same passage was included in the other work. However, for quotations from Ibn Wāșil's work pertaining to the period after the end of the year 597/1201 such references are omitted. As Abū Shāma's work ended at this point a comparison is not possible.

\section{Mode of emplotment announced: titles and guiding phrases}

From the fourth/tenth century onwards, Arabic authors in the different fields of knowledge tended to give their writings titles in rhymed prose $\left(s a j^{c}\right)$. By the time of the sixth/twelfth century nearly all historical works followed this convention, for example al-Nawādir al-ṣulțān̄ya wa-al-mahạsin al-Yūsufīya by Ibn Shaddād, ${ }^{12}$ Kanz al-muwaḅhidīn fī sīrat Ṣalāh al-Dīn ${ }^{13}$ by Ibn Abī TTayy and al-Fatḥ al-qussī fì al-fatḥ al-qudsī by 'Imād al-Dīn. ${ }^{14}$ This issue has not yet been discussed in depth in modern historiographical studies; due to the literary style of the titles they were probably thought to be irrelevant to an understanding of the texts themselves.

Ambros' (1990) study of rhymed titles is still the main examination of this phenomenon discussing works from the different fields of knowledge. It focuses on a semantic and formal study of rhymed titles, especially those written in Syria and Egypt from the seventh/thirteenth to the early tenth/sixteenth centuries. His study is an 'abstract' analysis, as it does not take into consideration the relationship between title and content - the issue at stake in the present study. Rather, he analyses the titles chosen (a total of 773 for this region) as an independent literary element.

In formal terms, Abū Shāma's and Ibn Wāṣil's titles roughly followed the standard pattern of the period in terms of issues such as length and rhymes. Following Ambros' method of counting, Abū Shāma's title consisted of 3 words and Ibn Wāṣil's title of 5 words while the average title length during the medieval period was 4 . Both authors employed the 'a-a' scheme to their titles (Rawdatayn - dawlatayn; kurūb Ayyūb), which was the most frequently employed rhyme scheme in such titles. ${ }^{15}$

The Kitāb al-rawdatayn fī akbbār al-dawlatayn and the Mufarrij al-kurūb fī akbbār ban̄ Ayy $\bar{u} b$ were, furthermore, typical titles since they are nominal phrases composed of two elements linked by a preposition $(f \bar{i})$. The second element (the 'thematic phrase') indicated, as in almost all rhymed titles of this period, the factual subject of the works: ${ }^{16}$ Abū Shāma announced that his text treated The Reports of the Two Reigns [of Nūr al-Dīn and Șalāh al-Dīn] while Ibn Wāṣil stated that his text was concerned with The Reports on the Ayyubids. In modern studies this unambiguous element of the 
title has been considered as the dominant indicator of the texts' purpose. In contrast, the first element, the 'guiding phrase', has hardly been mentioned as being relevant to a discussion of the authors' intentions: The Book of the Two Gardens and The Dissipater of Anxieties. ${ }^{17}$ However, in the context of their production and reception, the 'literary' parts of the titles were at least seen to be of equal importance. Contemporary and later references to these works tended to identify them via both elements of the title. ${ }^{18}$ Whenever the reference employed a shortened version of the title, it referred rather to the guiding phrase. ${ }^{19}$ Abū Shāma himself referred to his work simply as 'Kitāb al-rawdatayn'. ${ }^{20}$

Ambros shows that there were a limited number of semantic fields covered in the guiding phrase, that is, the choice was not entirely arbitrary, but followed established conventions. Some semantic fields, such as knowledge, support and preciousness, were frequently covered, while others, such as social relations and Islamic religion, did not appear at all. Not just the semantic fields but also the specific words used to cover them were drawn from a limited number of choices available. ${ }^{21}$ With ' rawda', Abū Shāma chose one of those terms which recurred frequently in titles from this period. ${ }^{22}$ Ibn Wāsill's 'mufarrij', on the other hand, was a rarely used term. ${ }^{23}$

Ambros briefly assumes that the choice of the guiding phrase was determined by two considerations. First, it was aimed at arousing specific positive connotations among the potential readership - that is, it served (in modern terms) 'publicity' purposes. Second, the author expressed in it his intention in writing his work, and made a statement on its purpose. ${ }^{24} \mathrm{I}$ will argue in the following that the guiding phrases were in addition markers for the mode of emplotment and were intended to prepare the reader for the following narrative structure.

Abū Shāma chose 'garden' (singular: rawda, plural: riyād/rawd) as the guiding phrase's decisive term ${ }^{25}$ indicating his mode of emplotment. The mode of Stasis was signalled by this metaphor, which depicted the periods treated in the text as enclosed unities. The two reigns were linked neither to the immediately preceding, nor the following, periods - they stood in dichotomous opposition to them. The metaphor expressed Abū Shāma's conviction that the exemplary reigns of Nūr al-Dīn and Șalāh al-Dīn were as outstanding and perfect as an idealized landscape. This use of 'garden' allowed a clear differentiation between the inside and the outside, between exemplary and bad rule.

Obviously, Abū Shāma was not the first to stress the outstanding qualities of these rulers. Authors such as 'Imād al-Dīn al-Ișfahānī had previously extolled Nūr al-Dīn and Șalāh al-Dīn. For example, he explained his choice of the title al-Barq al-Shāmī (The Syrian Thunderbolt) by the fact that the state of perfection under Nūr al-Dīn and Salāh al-Dīn had passed after the latter's death with the speed of lightning. ${ }^{26}$ Abū Shāma was thus able to rework and expand an existing tendency in previous historical writings. His original contribution was to set this glorification into a particular vision of his contemporary society.

The metaphorical use of garden for reign was frequent in medieval titles. The period of the Mamluk ruler Baybars, for example, was treated in a work entitled The Radiant Garden of al-Malik al-Zāhir's Biography. ${ }^{27}$ The reign of Ṣalāh al-Dīn itself 
was glorified during his lifetime in a poem entitled The Plains of Praise and the Garden of Exploits and Glorious Deeds on the Particularities of al-Malik al-Nāsirir [i.e. Salāh al$\left.\mathrm{D}_{\overline{1}}\right]^{28}$ - a poem included in the Rawdatayn. ${ }^{29}$ In the course of the Rawdatayn, Abu Shāma included statements such as: '[Nūr al-Dīn's] reign is hoped for and secured, his garden is watered and protected. ${ }^{30}$ Similarly, after Șalāh al-Dīn's conquest of Jerusalem the people came to the town to 'enjoy the flowers of his nobility in the spruce garden'. ${ }^{31}$ This use of the 'garden' metaphor for ideal rule was based on the idea that, with their idealized landscape, gardens also stood for territorial and social control. ${ }^{32}$

In addition, 'garden' simultaneously evoked strong spiritual associations, since it was also considered a kind of 'earthly paradise' imitating and reworking the Quranic paradise (janna) imagery. ${ }^{33}$ This use of garden is seen in a number of examples from different fields of knowledge. ${ }^{34}$ Abu Shāma reinforced the spiritual connotation of his work's title by employing the term garden in the dual. This paralleled references in the Islamic tradition: based on verses referring to paradise in dual, the Quranic paradise was generally interpreted as being divided into several levels. ${ }^{35}$ With this allusion to a bond between paradise and earthly garden Abū Shāma reinforced his basic outlook - as much as the reigns he dealt with in his work were clearly delimited, paradise was imagined as being enclosed by walls, not as an open landscape. ${ }^{36}$

Abū Shāma elaborated on this bond in the course of his text. While referring to Șalāh al-Dīn staying in Damascus shortly before his death, he stated that the "poor are grazing in the gardens of his alms' ${ }^{37}$ In the report immediately following Salāh al-Din's death he paralleled this reference to the earthly garden of rule with references to the celestial garden: 'He spent the nights always awake helping Islam/so that his time in the garden of paradise lasts long ${ }^{38}$ and 'May God place him in his gardens [jannāt]!'39

This metaphorical use of gardens for idealized rule as enclosed entities was reinforced in the Rawdatayn's introduction. Before starting his first report on the rule of Nūr al-Dīn, Abū Shāma stated: 'And I entitled it The Book of the Two Gardens on the Reports of the Two Reigns. How excellent was Habīb b. Aws ${ }^{40}$ when he wrote: "These years and its people elapsed/as if they - the years and the people - had been a dream"., 41

This idea of a period having elapsed as a dream without leaving further traces is visible in the macro-arrangement of the Rawdatayn itself. Abu Shāma started his work after the introduction with reports on Nūr al-Dīn. These did not refer primarily to concrete events during his reign, but consisted of his biography. This arrangement was unusual as such biographies were normally placed immediately after the announcement of the ruler's death. Although Abū Shāma described the events during Nūr al-Dīn's rule and his death at the usual place in the text, he decided to start his work with a eulogy of the first of his two ideal rulers.

Just as his work started with the praise of Nūr al-Dīn, it ended with a similar extended praise for Șalā al-Dīn, here at its usual place after the report on his death. Thus, the events described in his book were enclosed within these two biographical sections, which laid out in detail what Abū Shāma perceived as ideal rule. 
The biographies were meant to separate the preceding and the following periods from Abū Shāma's Rawdatayn, as much as a wall or hedge encloses the idealized landscape of a modelled garden. Nūr al-Dīn's biography was like a magnificent portal or gateway leading into the narrative. Șalāh al-Dīn's biography was equally significant in signalling its end, and in accompanying the reader with a final exposition of splendour on his return to the unordered world beyond the Two Gardens. The relatively short section following Ṣalāh al-Dīn's biography was merely included to spell out the very difference between his rule and his successors' rule - Abū Shāma did not contemplate the events beyond his idealized landscape as positively related to it, but portrayed them as its negation, as the fierce and barren outside world.

The opposition between the roots $f-r-j$ (dissipation) and $k-r-b$ (anxieties), as employed by Ibn Wāṣil in the guiding phrase of his title (Mufarrij al-kurūb), was commonplace in his period. ${ }^{42}$ It was, for example, employed to describe the population's relief after the Mongols' retreat from Damascus in 699/1300. ${ }^{43}$ By having chosen these terms as the decisive marker of the text's mode of emplotment, Ibn Wāṣil clearly set out his vision: the intention was to dissipate the anxieties of his audiences. The use of an active participle, in contrast to Abū Shāma's static noun, announced the mode of Process. The clear-cut limits of the Two Gardens, as well as the dichotomous view of history, were foreign to his text. His narrative was rather structured as a Process, implying continuous change while reassuring the audience that ideal rule had not been, and would not be, endangered by these changes. At the same time, this implied the denial that any reign, be it of Nūr al-Dīn, Șalāh al-Dīn, the Ayyubids in general, or any other individual or dynasty, could claim an outstanding position in history.

The root $f-r-j$ recurred in Ibn Wāșil's text in two principle meanings: first divine intervention and prophetic action leading to rescue/salvation; and second human action dissipating immediate danger/fear. It was the second meaning, which mainly indicated the purpose of his text: to dissipate the fear that the end of Ayyubid rule might signify a decisive turning away from exemplary governance. According to his vision, the continuity of good governance was not bound to a specific dynasty but a perpetual reality. His narrative, via the mode of Process, integrated the Ayyubids into this perpetual line of development.

The first meaning, deeds of salvation performed by God and his Prophet, was among the current meanings of these terms in medieval Arabic, ${ }^{44}$ and was taken up by Ibn Wāșil. In a document, which he cited in the framework of the biography of Nūr ad-Dīn, God is named the 'dissipater of anxieties' ('färij al-kurbāt'). The Prophet Muhammad was invoked here as the one who 'opened the narrow/dissipated the disturbing' ('farraja al-madāyiq'). These troublesome and frightening elements were driven away, to be replaced by the complementary 'paths of salvation' ('subul al-naja') and 'ways/paths' ('al-țarāyiq'), which were made clear and visible. ${ }^{45}$

However, such references were hardly ever linked to the immediate concerns of the political and military elite protagonists of his narrative. They were, rather, used as standard terms to invoke God and his Prophet in general circumstances. In contrast to Abū Shāma, who linked the gardens of this world to the celestial gardens, 
Ibn Wāṣil made no such connection. There is an isolated contrary example, however, the case of his Egyptian patron al-Malik al-Ṣālih Ayyūb who implored God, in one of the problematic situations during the frequent inter-Ayyubid fighting to 'dissipate the danger [lit. narrowness, anxiety] in which he is' ${ }^{46}$ After the danger was indeed dissipated, Ibn Wāṣil immediately limited such a direct divine intervention to this very case: 'An equivalent has not been heard in the books of history, this event was among the strangest and graceful events. ${ }^{47}$

Of more concern to Ibn Wāșil's text was the second meaning of the terms: anxieties dissipated as a result of human action. In such passages it was first demonstrated that initiatives taken by individuals at different levels of rule preserved ideal rule. This also shows that Ibn Wāșil's interest went beyond the level of rulers, in contrast to Abū Shāma, whose gardens were limited to this level. Second, such initiatives were not exclusive to a clearly circumscribed set of individuals or dynasties, but could refer to the reigns of the Fatimids, Ayyubids and Mamluks.

For example, the Fatimid vizier al-Malik al-Șāih Ṭalā’i i b. Ruzzīk (d. 556/1161) was honoured for his role in this sense (al-farrāj lil-ghumam):

Certainly, his vizier al-Șālih, the dissipater of anxieties, protects the religion, and the world, and the people of both

Wearing the glory whose gown nobody but the hand of the two crafts, the sword and the pen, wove. ${ }^{48}$

(Ibn Wāṣil, Mufarrij, I, 253, citing 'Umāra al-Yaman̄i)

The preceding verses for the Fatimid caliph al-Fä'iz (reg. 549/1154-555/1160) stressed his religious role: 'holy lights' (anwār muqaddasa) and 'prophethood' $\left(\right.$ nubuwa), while here the active political role of the vizier was praised. ${ }^{49} \mathrm{He}$ was the dissipater because he installed the idealized rule by protecting the people with the help of administration and military. Thus, the agent in this scene was not the ruler, that is, the caliph, but the vizier. The subject was furthermore the Fatimid dynasty an idea, which would have been foreign to Abū Shāma's outlook.

A second example where an administrator was crucial to the perseverance of governance referred to al-Qāḍ̄ al-Fādil (d. 596/1200), the senior administrator and close adviser of Șalāh al-Dīn. In 591/1195 al-Malik al-'Azīz (Ṣalāḥ al-Dīn’s son, r. until 595/1198) was confronted, after the death of his father, by a coalition under his uncle al-Malik al-'Ādil and his brother al-Malik al-Afḍal. Al-Malik al-'Azīz urged alQāḍ̄i al-Fāḍil to accept his uncle's offer of a meeting so that 'this anxiety [al-ghumma] is dissipated.' Ibn Wāṣil described this anxiety not as a general problem of disunity in the aftermath of Șalāh al-Dīn's death, but (employing the singular) he referred to the very specific situation as being a clearly circumscribed conflict within the family. In the 'common interest of all' (al-mașlaha al-shamila lil-kull), this disquieting situation was indeed resolved by the subsequent meeting. ${ }^{50}$

The guiding phrase's terms, and consequently the text's intention referred to other dynasties besides the Ayyubids, who throughout the text were denied a special position. Certainly, Ibn Wāṣil spelled out the Ayyubids' blessings, owing to such deeds 
as conquering Jerusalem and defeating the Fatimids. Deeds, which he described in the introduction as '[...] the reports on the Ayyubid rulers and all of their merits and glorious deeds'. ${ }^{51}$ In the main text he also repeatedly referred to their special qualities such as that (in contrast to preceding dynasties) an Ayyubid ruler did not kill another Ayyubid when he had the chance to do so. ${ }^{52}$ He criticized Ayyubid rulers who deviated from what he perceived to be these special qualities. ${ }^{53}$

However, what appears at first glance to be the normal tribute paid to the demands of patronage becomes a more complex issue in the actual text. As well as the Ayyubids, the 'merits and glorious deeds' also concerned both the Mamluks and preceding, closely linked and partly opposed dynasties such as the Fatimids and the Zangids. For example, when Ibn Wāṣil reached the point where the Ayyubid reign slowly faded away in the middle of the seventh/thirteenth century to the advantage of the Mamluks, he did not see the need to comment on the transfer of power. All major steps of the transfer, such as Aybak taking power and adopting the typical Ayyubid title of al-Malik al-Muizz, ${ }^{54}$ and the exclusion of the last nominal Ayyubid ruler's name from the kbutba, ${ }^{55}$ were reported without further comment.

He even described the downfall of the Ayyubids and the rise of the Mamluks in the decisive years 648/1250-649/1252 in the tone of the rather amused distant observer, not the engaged defender of a specific dynastic reign:

And in these two years (I mean [6]47 and [6]48) happened peculiar events. Never before anything similar to them has appeared in the chronicles. Among them: the enemy entered the land in great numbers and controlled its frontiers within one day, the sultan of the land died in this difficult situation so that the lands remained without ruler who could defend it, his death was concealed three months and coins and khutba remained in his name during this period [...], a woman was appointed ruler who was mentioned in the khutba on the pulpits and decrees were issued with her sign and this did usually not happen in Islam, she was then deposed, then another sultan was appointed, then deposed, then another sultan was appointed for five days, then the declaration of a sultan who was not in the lands, then the annulment of that [declaration]. ${ }^{56}$

(Ibn Wāṣil, Mufarrij, Paris BN, arabe 1703, fol. 97a)

Any explicit comment on the end of Ayyubid rule was absent in both this, and similar passages treating the period of transition.

The anxieties to be dissipated were not linked to the hope that the end of the Ayyubid dynasty could be prevented, but were connected to the fear that the fall of the Ayyubids would lead to decisive changes concerning ideal rule. Writing in Hama, the last remaining Ayyubid enclave in Syria in the late seventh/thirteenth century, he acted in a context of general insecurity with regard to the continuation of the Ayyubid dynasty. ${ }^{57}$ This did not induce him to act as a panegyric for the dynasty hoping for a renaissance; rather he tried to dehistoricize the values incorporated 
(according to him and his audience) by the Ayyubids into a timeless continuity of ideal rule irrespective of the concrete dynasty concerned.

This was not the ideal rule of Abū Shāma, but one where rulers did err often, or where unjust rulers appeared for short periods. Certainly, rulers such as Șalāh al-Dīn played important parts in his narrative, but this never reached the point of Abu Shāma's mode of Stasis, where such rulers were beyond the normal developments of history. The mode of Process integrated such rulers into the perpetual continuity of good governance.

Thus, the guiding phrases are decisive for understanding the text's mode and intention. Abū Shāma and Ibn Wāșil prefigured their texts in opposed modes of emplotment, which endowed the quite similar material included in the narratives with different meanings. This is not to claim that the titles must exclusively be understood in relation to the mode of emplotment. Abū Shāma's choice of title, for example, can also be seen against the background of a work having expressed a contending version of the past: Ibn Tuwayr (d. 617/1220), an Egyptian Sunni administrator under the Fatimids and the Ayyubids, had entitled his chronicle Nuzhat al-muqlatayn $f^{\bar{\imath}}$ akbbār al-dawlatayn (The Two Eyes' Entertainment on the Reports of the Two Rules).

This chronicle strove to carve out a historical continuity between the Fatimids and the Ayyubids. Abū Shāma, as author of an anti-Fatimid work, could not accept such an interpretation, which stood in opposition to his own Zangid-Ayyubid continuity. Writing some seventy years later his title echoed Ibn Țuwayr's title in the use of the dual (muqlatayn-rawdatayn), the rhyme scheme and in the choice of the thematic phrase ( $f \bar{\imath}$ akbbār al-dawlatayn). ${ }^{58}$ He positioned his narrative of the outstanding qualities of Nūr al-Dīn and Șalāh al-Dīn against this opposed vision of a FatimidȘalāh al-Dīn period of excellence. However, the exalted position he ascribed to his two rulers excluded the direct adoption of Ibn Țuwayr's title. Rather than the mundane 'entertainment' he chose the more adequate 'garden' to announce his mode of emplotment.

In contrast, for his summary of a historical work on the reigns of the Khwārazmshāhs 'Alā' al-Dīn and Jalāl al-Dīn Abū Shāma chose a title identical to Ibn Tuwayr's choice: The Two Eyes' Entertainment on the Reports of the Two Rules [of 'Alā' and Jalāl]. He considered these rulers of the eastern lands, who 'subjugated mankind', 59 to be of interest only because of their encounters with the Mongols. For such second-rate rulers (as Abū Shāma saw them) Ibn Ṭuwayr's title could be indeed applied without any changes.

\section{Mode of emplotment applied 1: the narratives' final sections}

The prefiguration of the narratives in the modes of Stasis and Process led to decisively different decisions in shaping the final passages of the texts. Abū Shāma's text was clearly delimited by Șalāh al-Dīn's biography, the final exposition of splendour. His narrative was brought to a closure, as further substantial extensions would have 
undermined its underlying message. Ibn Wāșil's narrative, on the contrary, had no such strict delimitation, but rather dwindled away and stopped without any final comment. His narrative's final section cannot be described as a closure, but rather as an open end. The flexibility of his text is visible in the rival versions of the final section in the extant manuscripts.

Abū Shāma's decision to bring the narrative to a definite closure is clear from comments on the changing state of affairs. One example is that he entitled the report immediately following Șalāh al-Dīn's death, 'Chapter on the division of his realms among his sons and brothers [...]'. ${ }^{60}$ This stress on the end of unity and the start of disintegration marked, for him, the end of his enclosed gardens. The Stasis was interrupted for a limited period of crisis in order to introduce the only change possible in the narrative: the sudden transition from one state of affairs to another, clearly opposed, state of affairs. This latter state was in dichotomous opposition in the sense that it symbolized the inversion of the preceding exemplary period. However, although it was in content opposed, it was again underlain by a similarly static and unchanging mode.

Ibn Wāṣil tellingly entitled the quite similar report 'Mention of how the situation concerning the realms consolidated after the death of the sultan [...]. ${ }^{61}$ In accordance with the prefigurative decision on his text's mode, the narrative continued to describe the linear course of events. It was the mode of Process where good rule was a perpetual reality, which allowed him to stress the aspects of stability and continuity after Șalāh al-Dīn's death. The report subsequently mentioned, with great care, which Ayyubid prince took power in the various provinces of the dynasty's realms: 'His son al-Malik Afḍal consolidated his reign in Damascus [...] and in Egypt al-Malik al'Azīz [...] and in Aleppo al-Malik al-Zāhir [...]', etc. In addition, it also listed the amirs who held minor places or castles with certain independence. ${ }^{62}$ Ibn Wāṣil's text had a 'The King is dead! Long live the King!' flavour, which almost had here the meaning of 'The King is dead! Long live all the Rulers - whoever they may be!'

A second example illustrating the different closures in the two texts is Abu Shāma's inclusion of a passage ascribed to al-Qāḍ̄ al-Fāḍil, which concluded his first version of the Rawdatayn. In this passage the aspects of disunity and fall recur again in the form of a general comment:

As to this dynasty: the fathers had agreed so they conquered, their sons disagreed so they perished. If a star sets, it is no expedient to make it rise again! If a cloth starts to be pierced it will be surely torn to pieces! O what a thought that the path of fate can be blocked - its paths were ordained. If God is with one side against the other, God will sustain the one with whom he is. ${ }^{63}$

(Abū Shāma, Rawḍatayn, IV, 434)

This final citation reiterated the theme of the aforementioned quotation from the introduction: 'These years and its people elapsed/as if they - the years and the people - had been a dream. ${ }^{64}$ As much as the biographies of Nūr al-Dīn and Șalāh 
al-Dīn sandwiched the text, these citations opened and closed it with explicit statements.

A striking feature of Abū Shāma's final section was that he briefly continued the narrative after the death of Șalāh al-Dīn. Certainly, Abū Shāma covered the period up to the ruler's death (more than 1700 pages in the 1997 edition used here) much more extensively than the post-Ṣalāh al-Dīn period (some eighty pages). However, he could have chosen the same closure as Ibn Shaddād in his biography of this ruler, where the narrative ended with the ruler's death. ${ }^{65}$ In Ibn Shaddād, the only extension was a brief enumeration of all the conquests of Salāh al-Dīn, that is, a kind of summary of his successes. ${ }^{66}$

At first glance, Abū Shāma's extension of his narrative seems contradictory to the underlying mode of Stasis. However, this passage was not a simple extension of the previous narrative, but rather a contrapuntal accentuation to it. It reinforced the impression of glorious splendour evoked in the main part by depicting the aftermath in strongly contrasting terms. In the course of this final section the narrative changed remarkably.

First, the importance of the politico-military events, typical of the Rawdatayn, decreased. In this final passage obituary notices started to play a much more significant role. ${ }^{67}$ Here, the division of the lands again showed the decline in the post-Rawdatayn period. In contrast to the ideal rule of Nūr al-Dīn and Șalāh al-Dīn, the deteriorated state of affairs in this period rendered reports on the politicomilitary developments useless. Second, a change in mood became apparent: the final year 597/1200-1, for example, appeared as a bundle of negative reports: deaths of outstanding people, plans of murder within the Ayyubid family and famine in Egypt. ${ }^{68}$ Ibn Wāṣil started this same year rather with a detailed enumeration of which ruler was in which town and included hardly any of Abū Shāma's reports. ${ }^{69}$

The very last passage of the Rawdatayn was merely a list of the main protagonists of this period, with dates of deaths and a reference to the inter-Ayyubid struggles, inevitable with Abū Shāma:

Al-Malik al-Afụal died in Sumaysāt in 622, he was carried to Aleppo where he was buried. Al-Malik Zāhir died in Aleppo in 613. In this year died also [...] al-Kind̄̄ and others. Al-Malik al-'Ādil [...] died in Damascus in 615 and his son al-Malik al-Mu'ażam at the end of 624. His two sons al-Ashraf and al-Kāmil died in 635 - may God have mercy upon them and grant fortune to those who remain of their dynasty and settle the dispute among them. Amen. ${ }^{70}$

(Abū Shāma, Rawḍatayn, IV, 486)

With his final list of conquered places, Ibn Shaddād had referred the reader back to the lifetime of Șalāh al-Dīn. Outwardly, Abū Shāma chose a different strategy by concluding his narrative with an outlook on the events to come. However, this list, as much as the entirety of his post-Ṣalāḥ al-Dīn section, in fact served the same 
purpose as Ibn Shaddād's list. The stress on the subsequent deterioration of the affairs sent the reader again back to the exemplary period. The Dhayl to the Rawdatayn played a similar role to this final section. While it again seems contradictory to continue a work brought to such a closure, the Dhayl can also be read as mirroring the narrative of the Rawdatayn in a contrapuntal manner. Although the Dhayl's title implied a direct continuation of the Two Gardens, the relationship between the two works is more complex. ${ }^{71}$

The difference between the outlook of the Rawdatayn and the Dhayl has been previously remarked upon in scholarship. One argument runs that the author's resignation was crucial to this shift; according to this interpretation, he tried to induce rulers in the Rawdatayn to follow 'a course of conduct leading to prosperity'. However, owing to his experiences and observations he finally gave up hope of change and, in the Dhayl, concentrated on recording his immediate environment. ${ }^{72}$ The basic weakness of this argument is the assumption that the Dhayl was indeed written subsequent to the Rawdatayn. However, the aforementioned early introduction to the Dhayl shows that this work was started earlier. Both works have to be seen as a unit and were partly composed simultaneously. The differing outlooks should not be described as a shift, but as intimately linked expressions of the very same perspective on present and past.

Like the final section of the Rawdatayn, the Dhayl largely disregarded political events. As shown previously, the focus was on obituary notices, reports linked to other events within the community of religious scholars and autodocumentary passages. The interest of the author in his contemporary society was almost exclusively focused on religious scholars. Abū Shāma considered these scholars to be the decisive group for preserving the idea of ideal rule - like the author himself, who played an important role in the Dhayl via his extensive sections of autodocumentary, or rather autorepresentative, material. If rulers appeared in the Dhayl, they were depicted in terms quite different to Nūr al-Dīn and Șalāh al-Dīn: the mode of Stasis in the Rawdatayn in the form of ideal rule was reworked in the subsequent period as the continuous succession of unjust rulers: 'Whenever I said: the rule of the tyrant/ ended, another one comes upon us'. ${ }^{73}$

This focus, and the difference to the Rawdatayn's politico-military narrative, is for example evident in the Dhayl's reports on the year 634/1236-7. Of the total 44 lines, 26 were devoted to an Andalusian scholar coming to Damascus, 7 to obituary notices of scholars, 3 to the birth and death of Abū Shāma's son Muhammad, and 2 lines to that year's pilgrimage. Reports on the Mongol advance took 4 lines and the death of 'several rulers' ( jamā'a min al-mulūk) 2. ${ }^{74}$

Taking Ibn Wāșil's narrative on the same year in his Mufarrij into the picture, the Dhayl's focus is seen more clearly. The factual content of the Rawdatayn and the Mufarrij in the respective years had been quite similar. Ibn Wāṣil continued his narrative to the end in the same vein, in contrast to Abū Shāma's contrapuntal Dhayl. The total of 254 lines devoted by Ibn Wāṣil to the year 634/1236-7 thus show a completely different picture from Abū Shāma's Dhayl: the focus remained on politico-military events without any reference to most of the reports included in the 
Dhayl. Most prominently featured were reports on the inter-Ayyubid politics, with eighty-four lines. The remaining narrative included the death of one of the 'several rulers', al-Malik al-'Azīz of Aleppo, and the settlement of his succession (77 lines), a battle with the Crusaders (27), the appearance of the Khwārazmian mercenaries on the Syrian/al-Jazinrian scene (26) and similar reports of short length. ${ }^{75}$

The most striking feature of the final passages in Ibn Wāșil's work is that the text had no closure. It broke off, according to the two different manuscripts, either within the year $659 / 1261^{76}$ or at the end of the year 661/1263. ${ }^{77}$ Ibn Wāșil did not include a final comment in his text. As no decisive break occurred, the narrative could just continue or break off at any point within the Mufarrij itself. The mode of Process did not require clear limits to be drawn: the idea of exclusivity was absent, and any part could be employed to represent the overall picture.

The open-endedness of his narrative is, for example, visible from the content of the reports included in the final section: these were not closely linked with the factual 'thematic phrase' of the work's title promising reports on the Ayyubids. Even after the rule of the Ayyubid dynasty in Egypt had ended completely - that is, after the name of the last nominal ruler of this family had been dropped from the khutba in $652 / 1254$, the narrative continued without changes. The focus remained on Egypt, largely excluding the remaining Ayyubid entities in Syria. The Mamluks were now the protagonists in his text, which continued to report the events of the next seven years.

Owing to this open-endedness, the scribe to whom Ibn Wāsil dictated the work felt authorized to append his supplement directly to the text of the main work. Although dissimilar versions of this supplement exist, ${ }^{78}$ both are ascribed to the previously mentioned Hamawian secretary 'Alī b. 'Abd al-Rahīm, to whose grandfather Ibn Wāṣil was indirectly linked. ${ }^{79}$ Ibn 'Abd al-Raḥ̄m considered the narrative not only suitable for adding a supplement, but in 1 of the 2 versions he also inserted an extended section on the Mamluk ruler al-Malik al-Zāhir Baybars before the start of his supplement. ${ }^{80}$ This section was based on al-Raw al-zähir fī sìrat al-Malik alZāhir (The Radiant Garden of al-Malik al-Zāhir's Biography), ${ }^{81}$ a praise of the Mamluk ruler. Written by Baybars' trusted secretary Ibn 'Abd al-Zāhir (d. 692/1292), ${ }^{82}$ it dealt in detail with the ruler's career, depicting him in the most favourable light.

The Mufarrij was thus given an important extension very soon after its composition. Although the title referred to the Ayyubids, the inclusion of yet another praiseworthy ruler posed no problems for the supplement's author. This underlines the flexibility of the Mufarrij's approach, which conformed to the mode of Process: the continuous dissipation of anxieties. Ibn Wāșil exemplified his concept of ideal rule by taking the Ayyubids (quite an obvious choice in his place and period), but this ideal was also to be found in the preceding Zangid rule and in the following Mamluk rule.

On the other hand, no subsequent writer ever extended the Rawdatayn after Abū Shāma had claimed this textual space for himself. The static nature of his two enclosed gardens made the work unsuitable for such changes: of the nearly twenty surviving manuscripts of the Rawdatayn, none has a supplement or any significant 
insertions. Because of the different concept of Abū Shāma's Dhayl, even his own work can only be understood as a contrapuntal continuation of the original work. In contrast to the Mufarrij, the Rawdatayn's textual format thus proved to be highly stable.

\section{Mode of emplotment applied 2: historicizing the narratives' protagonists}

In addition to the narratives' final section, historicization offers an avenue to discussing the two authors' modes. The choice of placing one's protagonists into specific historical continuities or discontinuities evoked particular associations among audiences. References to preceding periods in the Mufarrij and the Rawdatayn can be divided into three thematic groups referring respectively to pre-Islamic times, to the Golden Age (i.e. the period of the Prophet Muhammad and the four following caliphs until 40/661) and to the subsequent Islamic - mainly Umayyad and early 'Abbasid - history. As discussed later, the authors' room for manoeuvre was limited in this area as they encountered versions which were, to some extent, canonized. Furthermore, their works did not focus on these periods, but merely referred to them in order to present specific versions of the authors' immediate past and present. Their main aim here was not to rework the established canon, but to offer specific perspectives on their protagonists.

The main difference between Ibn Wāṣil and Abū Shāma in terms of historicization concerned the number of references in their works to earlier periods. While Ibn Wāṣil made only occasional references, Abū Shāma made them in abundance for all three thematic groups. Such references were, for Ibn Wāṣil, of less importance since he considered the period treated in his text to be of equal standing with most of the preceding periods. This similarity between past and present did not demand a continuous stress: the decision to emplot the narrative in the mode of Process had already prefigured the historical field in this regard.

Abū Shāma, though, argued the specificity of Nūr al-Dīn's and Ṣalāh al-Dīn's period by linking and/or contrasting it with preceding periods. In particular, his many references to early Islamic history showed the continuous need to tie the period he was dealing with to momentous examples of the past. The mode of Stasis demanded clear breaks with the periods immediately preceding and following. These were only to be achieved by linking this period to more remote instances of his idealized vision of society.

His employment of historicization also had broader implications, because his focus was on the Golden Age period. The stress that this period was the main point of reference for ideal rule in the present was essential to the revivalist claim to authority as proposed by Abū Shāma. He implicitly argued that only those rulers adhering to the example of the early period were righteous in their governance. Thus, only those individuals with a sufficient knowledge of this period (i.e. religious scholars in the vein of Abū Shāma) could guide rulers towards good governance. The focus on religious scholars in the final sections of the Rawdatayn and in the Dhayl was thereby substantiated. Ibn Wāșil, on the contrary, assured the rulers that their practice of 
governance was unproblematic as it stood. His version of the past dispensed the ruling elites from constantly seeking the guidance of religious scholars with respect to historical precedence. ${ }^{83}$

\section{Golden age: the prophet and the four rightly guided caliphs}

Of the three thematic groups mentioned earlier, Ibn Wāṣil and Abū Shāma made the most frequent references to the Golden Age. In Sunni Islamic historical writing and other genres, references to the Golden Age of the Prophet Muhammad and the following 'Rightly Guided' caliphs were common currency. By the late first/seventh century, historicization had become the main form of legitimization and the Golden Age had crystallized as the main point of reference. ${ }^{84}$ In texts preserved from the late second/eighth and the third/ninth centuries the notion of the early founding period's exemplarity was one of the main themes. In the field of political theory, for example, later writers considered that the conditions for the true imamate were completely fulfilled only in this period. ${ }^{85}$

The Golden Age, the central founding myth of the Islamic umma, had to be appropriated and inserted into one's historical continuity - or discontinuity. Owing to the important role this period played in the subsequent centuries, it was the obvious point of reference to historicize one's vision of the contemporary state of affairs. The upsurge of works written on the early period during the third/ninth century, for example, has to be considered in the light of contemporary debates on the shape of the caliphate. ${ }^{86}$ These references were very flexible, since writers of different ages and groups could opt for a wide variety of diverging and conflicting positions by citing relevant reports.

The construction of a founding Golden Age could, arguably, be called an anthropological standard. Whenever individuals coalesce around a specific identity, it becomes part of their collective memory. In the modern period the most obvious example has been the idea of the nation's remote Golden Age ${ }^{87}$ endowed with characteristics such as purity and freedom from suppression. This myth has been 'a key element in the creation of closures and in the constitution of collectivities'. ${ }^{88}$ In the case of the early Islamic period, it was the very canonicity ascribed to a set of texts, which not only allowed and necessitated their constant reinterpretation and revalorization, but also allowed an inexhaustible range of meanings. ${ }^{89}$ Thus, the main point of interest is not that Abū Shāma and Ibn Wāṣil simply employed the Golden Age, but what meaning those references took in the narratives.

Ibn Wāsil's references to this period were particularly abundant in the context of Șalāh al-Dīn's conquest of Jerusalem. This was a standard feature of the chronicles of the period, as Jerusalem had become a focal point for counter-crusading calls during Nūr al-Dīn's time. ${ }^{90}$ Ibn Wāṣil did not stand back from his contemporary chroniclers and included comparisons between Salāh al-Dīn and 'Umar b. al-Khațāāb (d. 23/644), the first Muslim conqueror of Jerusalem and second caliph, ${ }^{91}$ "who should have seen the deeds of his successor' ${ }^{92}$ In a letter written to the caliph in 
Baghdad, Șalāh al-Dīn's conquests were set into an even more authoritative continuity with the Prophet Muhammad by depicting them as the fulfilment of a Quranic prophecy. ${ }^{93}$ References to Nūr al-Dīn were less frequent but were endowed with similar authoritative status. For example, his learned sessions with the religious scholars were similar in piety to those of the Prophet Muhammad. ${ }^{94}$

Unlike Abū Shāma, Ibn Wāṣil nevertheless applied the idea of the Golden Age to a wider variety of the individuals appearing in his narrative. As might be expected, he described Șalā al-Dīn as the most outstanding figure since the periods of the four caliphs, after his victory over the Crusaders at Hatṭin (583/1187). Immediately afterwards, however, Ibn Wāșil honoured not only Nūr al-Dīn with the same description but celebrated the Mamluk ruler Baybars as even more outstanding. ${ }^{95} \mathrm{He}$ similarly included a letter to the caliph regarding the inter-Ayyubid struggle following Șalạ̄ al-Dīn's death. In this letter the conflict was presented as being the same as the struggle over leadership between the third caliph 'Uthmān (d. 35/656) and the fourth caliph 'Alī (d. 40/661) - a reference excluded by Abū Shāma in the relevant passage. ${ }^{96}$ For Ibn Wāṣil, characteristics of the Golden Age could be detected throughout the periods covered in his chronicle - beyond the confines of Nūr al-Dīn and Șalāh al-Dīn's periods.

At the same time references to the Golden Age were occasionally underlain by a somewhat ironic tone. Ibn Wāṣil recounted in detail the story of a jurisconsultant who participated in a learned session in Baghdad. As the caliph was listening the jurisconsultant recited the verse: 'If you had been present at the day of al-Saqifa/you would have been the leader and the most magnificent imam. ${ }^{97}$ This rather unusual attempt to place the present caliph on a more elevated level than the four 'Rightly Guided' caliphs and other Companions of the Prophet incited the wrath of some of those present. The jurisconsultant was finally banned from the town by caliphal decree after his abortive attempt at panegyric poetry. Ibn Wāṣil ended this passage not with a condemnation, but by praising this scholar as a 'virtuous' friend of his, whom he met in Cairo. ${ }^{98}$

Abū Shāma's links between the Golden Age and Nūr al-Dīn and Ṣalāh al-Dīn were much more abundant. These links did not just derive from the passages referring to Jerusalem, but were scattered throughout his narrative. In a dream, the Prophet and the Companions were seen to visit Șalāh al-Dīn's grave, bowing down in respect. ${ }^{99}$ Șalāh al-Dīn himself was described 'as if the Prophet Muhammad [eulogy] sent [him] to the one who is in need of his support' ${ }^{100}$ Similar statements referred to Nūr alDīn who united the virtues of the four caliphs. ${ }^{101}$ In sum, these two followed the way of the 'Rightly Guided caliphs', disproving those who claimed that such an exemplary rule could not occur once again. ${ }^{102}$

However, their two reigns had passed and it was not possible to extend this historicization to rulers preceding and following Nūr al-Dīn and Șalāh al-Dīn, as Ibn Wāṣil had done. The only exception was a link twice established between Șalāh alDīn's uncle and predecessor in the Egyptian vizierate, Asad al-Dīn Shīrkūh, and the caliphs 'Umar and 'Ali. ${ }^{103}$ Nevertheless, compared to the frequent references established for Șalāh al-Dīn and Nūr al-Dīn these two instances are not significant. 
Most importantly, Abū Shāma used the Golden Age motif to underline the uniqueness of these two rulers vis-à-vis most other rulers of the post-Golden Age period. This stress on their uniqueness was crucial to preserve the clear limits of the Rawdatayn. Thus, the day of Șalāh al-Dīn's death was a date on which 'Islam and the Muslims were afflicted as they had not been since the loss of the Rightly Guided caliphs'. ${ }^{104}$ This comparison was obvious as Abū Shāma described Ṣalāḥ al-Dīn’s conquests as being unequalled by any other since this early period. ${ }^{105}$

Abū Shāma's most significant concept in this context was 'jāhilīya'. This term generally referred to the pre-Islamic period, which was endowed with characteristics opposed to what was perceived to be Islamic. Jähilīya was the byword for barbarism, paganism and ignorance. Abū Shāma employed the term for the pre-Nūr al-Dīn period, as it was only with this ruler that the preceding 'jābilizya'106 was ended. Implicitly, it is in the aftermath of Șalāh al-Dīn that this despicable state of affairs returned. By employing one of the central terms for the construction of the Golden Age in his narrative on a later period, Abū Shāma decisively reinforced his vision of a complete break between Nūr al-Dīn and Șalāh al-Dīn on the one hand, and the preceding and the following periods on the other.

Considering this vision, the dual of the Two Gardens of Abū Shāma's title referred not only to Nūr al-Dīn and Șalāh al-Dīn, but also to the duality of the exemplary periods. Nūr al-Dīn and Șalāh al-Dīn succeeded in re-establishing an ideal period which, according to Abū Shāma, had existed almost exclusively during the lifetime of the Prophet Muhammad and the four following successors. By firmly connecting these two periods and clearly delimiting them from preceding and following spans of darkness/jäbilīya, so that their excellence was beyond any question, Abū Shāma created a distinct image of his decaying present. His contemporaries arguably understood the author's intention to advocate a return to, and revival of, the early Islamic period. When Sa'd al-Dīn Muhammad (d. 656/1258), the son of the grand mystic Ibn al-'Arabī, wanted to borrow the Two Gardens, he praised Abū Shāma with the words: 'With you the community of Islam's youthfulness returned / O you whose fatwas rendered plain its righteousness!'. ${ }^{107}$

Following Assmann's study on cultural memory in ancient civilizations, one could describe the different uses of the Golden Age historicization in Ibn Wāṣil's and Abū Shāma's texts more generally. Abū Shāma employed the myth of the Golden Age in a 'contra-presentist' (kontra-präsentisch) usage, that is, the present was described in a way which underlined the missing, the disappeared and the lost of the past. ${ }^{108} \mathrm{He}$ closely linked the periods of Șalāh al-Dīn and Nūr al-Dīn to the initial Golden Age, and delimited it clearly from preceding and following periods. The Golden Age had an affirmative function with respect to the periods of Șalăh al-Dīn and Nūr al-Dīn, reiterating the theme of exemplarity. However, as his narrative was largely aimed at condemning the contemporary state of affairs, the central usage of the Golden Age myth was 'contra-presentist'.

Ibn Wāṣil, on the contrary, included references to the Golden Age in the vein of the 'founding use', which depicted the present as the teleological and necessary outcome of the past. The employment of the myth here merely reinforced the vision that 
present and past were not separated by clear boundaries, but underlain by the same virtues and characteristics. In the mode of Process, the stream of past events was presented basically as a continuous and never-stopping reiteration of an early period.

\section{Pre-Islamic (ancient) bistory}

Muslim authors of the formative and medieval periods had a strong interest in preIslamic history. One of the reasons for this was the Quran-based belief that every community had a Prophet. Those earlier communities had been doomed because of their ignorance or corruption of the divine message; the study of this past was therefore considered a source of moral lessons, which were crucial for avoiding deviation from the right path. ${ }^{109}$

However, in the genre of chronicles, the picture was more complex as links to the pre-Islamic period could take two main directions. On the one hand, the author could refer to what was perceived as the non-Islamic heritage of the Near East. In the context of the historical writing under consideration, this mainly included the Egyptian Pharaohs and the Persian Sasanid dynasty. On the other hand, the author could refer to pre-Islamic history as appropriated by the Muslim tradition. Most importantly, this included the sequence of prophets, who were defined as the predecessors of Muhammad's teachings. Of special importance here were the personalities of Yūsuf (Joseph), Iskandar/Dhū al-Qarnayn (Alexander the Great), ${ }^{110}$ Sulaymān (King Solomon) and Dāūu (King David).

Even so, the distinction between perceived non-Islamic and proto-Islamic history before the rise of Islam was not so clear-cut. Although the Pharaoh generally served as an example of paganism and tyranny, attempts were made occasionally to fit individual Pharaohs into salvation history. ${ }^{111}$ And in the same way, the pre-Islamic Persian history was sometimes adapted to this pattern. ${ }^{112}$ Here, the Quran-based vision of the ever-present Prophet for each community recurred. However, Abū Shāma's and Ibn Wāṣil's texts followed the mainstream tradition in the chronicle genre where such attempts were rare.

The main point in common between Abū Shāma and Ibn Wāṣil regarding this period was references to the link between Yūsuf and Șalāh al-Dīn. This link had been well established by the time they composed their chronicles, and both Ibn Wāșil and Abū Shāma took up this historicization with a number of references. ${ }^{113}$ One of the 'classical' scenes in this regard was Ṣalāh al-Dīn welcoming his father after ascending to power in Egypt. This moment was compared to Yūsuf welcoming his father Ya'qūb after having risen to power at Pharaoh's court. ${ }^{114}$

For Ibn Wāsil, however, the references to the Islamized ancient history ended there. He did not establish any other links beyond this literary convention, which - owing to its dominance during the seventh/thirteenth century - could hardly be excluded from his writings. Abū Shāma, in contrast, repeatedly linked the Prophets $D \bar{a}$ ūd and Sulaymān to Nūr al-Dīn ${ }^{115}$ and Șalāh al-Dīn. ${ }^{116}$ This pushed the link between the ideal periods of the two rulers and the Golden Age period further by including references to outstanding figures of Islamic salvation history. This continuity was crucial 
for the author to develop a vision of a row of ideal periods interrupted by spans of jăhilizya, such as the one preceding and following the reigns treated in his text.

At the same time, references to non-Islamized ancient history rarely figured in Abū Shāma's text. They referred mostly to enemies who are depicted as the Fir'awn (Pharaoh), the eponym for the tyrannical and haughty ruler in Islamic tradition. ${ }^{117}$ The second set of references referred to the Sasanid dynasty, whose rulers, in Muslim tradition, were generally named Kisrā. This dynasty was viewed with mixed feelings: it inspired awe (because of its might), and envy (because of its lavish court life associated with luxury). They were additionally revered for a number of inventions ascribed to them in different fields. ${ }^{118}$ But these characteristics were contrasted with 'Muslim' spiritual values, and the figure of Muhammad symbolizing lack of pretence. In this sense Kisra came to be seen as the main enemy of Islam, ${ }^{119}$ a sense taken over by Abū Shāma.

His references to the Sasanid kings were mainly made in order to show the greatness of contemporary rulers, for example to display the superiority of Nūr al-Dīn over this tradition. ${ }^{120}$ The only exception was a reference to Ṣalāh al-Dīn's descendants who should be 'for Islam Kisrās', that is, achieving the same degree of greatness as the Sasanid kings. ${ }^{121}$ Nevertheless, against the background of Abū Shāma's pessimistic vision of the post-Ṣalāh al-Dīn period this 'praise' could be read ambiguously.

Ibn Wāsil employed references to non-Islamized ancient history by stating the superiority of present rulers over the ancient Sasanid kings, too. ${ }^{122}$ However, he displayed a distinctively stronger interest in previous traditions than Abū Shāma, for example when he retold the story of 'a female king of Homs in ancient times who cut off the Orontes River', ${ }^{123}$ or mused about the use of a building in pre-Islamic Jerusalem, which had become a madrasa. ${ }^{124}$ His interest was also evident in the occasional use of non-Islamic dates for defining 'momentous' events, such as the birth of his future patron al-Malik al-Muzaffar of Hama in 657/1259. In the text he also specified the date according to the Era of Alexander as current among Eastern Christians (year 1570), and according to the Persian/Zoroastrian Era Yazdigird, which had started with the accession year of the last Sasanid king (year 632). ${ }^{125}$ This awareness of the different systems to date present events could be seen as a sign that the preIslamic traditions still had relevance for him. They were not merely a remote set of potential references for events and individuals, but continued to exist in parallel with the Islamic framework.

As much as Ibn Wāṣil referred to pre-Islamic history, which was not necessarily part of a proto-Islamic tradition, he also displayed an interest in non-Islamic current affairs. For example, he was keenly interested in educating his readers about the intricate conflicts between the Holy Roman Emperors and the Pope during the seventh/ thirteenth century. ${ }^{126}$ And in the same vein he discussed the position and meaning of the title 'Roi de France'. ${ }^{127}$ These passages were probably informed by his extended stay at the Staufer court in southern Italy where he would certainly have become acquainted with some of the issues in Latin Europe. However, he also discussed the nomadic lifestyle of the Mongols, their beliefs, their laws (yasa) and their previous conquests when they appeared in the Saljuq lands. ${ }^{128}$ 
This interest in the non-Islamic past and present was also an outcome of his immersion in the rational sciences, which opened up sympathetic avenues to different traditions. Here again, these avenues, in combination with the prefigurative decision on the mode of Process, arguably precluded clear delimitations. With regard to 'Muslim' history, past and present gained, in his narrative, homogeneity in a vertical sense. But here - in non-Muslim history - the homogeneity extended horizontally: the borders between the inside 'us' and the outside 'them' were considerably weaker than in Abū Shāma's text. For example, his description of the court in southern Italy was far from the standard approach towards the 'Franks' in other chronicles, which varied between hostility and disregard. His indifference towards favouring the one or other dynasty among the Zangids, Fatimids, Ayyubids and Mamluks were translated here on a different level.

\section{Post-Golden Age period}

References to the period between the Golden Age and the start of the chronicles in the fifth/eleventh century were rare in Abū Shāma's and Ibn Wāṣil's narratives. Nevertheless, as well as the pre-Islamic and early Islamic periods, this time span offered a set of potentially highly significant individuals. Abū Shāma, especially, drew on this potential by referring to two individuals: the Umayyad caliph 'Umar II b. 'Abd al-'Az̄̄z (d. 101/720) and the 'Abbasid caliph Hārūn al-Rashīd (d. 193/809). Both individuals had become legendary figures whose outstanding qualities were widely celebrated in Muslim tradition.

Furthermore, both were regarded as ephemeral continuations of the early Islamic Golden Age. 'Umar II was the great-grandson of the second Rightly Guided caliph 'Umar b. al-Khațtāb, and was sometimes referred to as the fifth Rightly Guided caliph. In contrast to most of the remaining Umayyad rulers he enjoyed a positive representation in Muslim tradition. ${ }^{129}$ Similarly, the reign of the legendary al-Rashīd was seen as the apogee of the 'Abbasid dynasty. Arabic sources of the following centuries depicted him as an idealized pious leader. The authors probably strove to depict him as akin to 'Umar b. al-Khațtāb when describing practices, such as touring the streets under the cover of dark. ${ }^{130}$

Abū Shāma compared both Nūr al-Dīn and Șalāh al-Dīn to these outstanding figures of post-Golden Age history. When celebrating Nūr al-Dīn's asceticism after the report on his death, Abū Shāma described him as emulating 'Umar II, 'the ascetic among the caliphs' (zāhid al-khulafă') by rarely showing delight for panegyrics. ${ }^{131}$ During their voyage to Alexandria in 577/1182, Șalāh al-Dīn and his sons attended the reading of Mālik b. Anas' (d. 179/795) fiqh compendium al-Muwatța' as auditors. This was purportedly just the second occasion of a ruler seeking knowledge or tradition (talab al-ilm), preceded only by al-Rashīd and his sons' attendance on Mālik himself: 'He [Șalāh al-Dīn] took the place of al-Rashīd, his [two sons] 'Alī and 'Uthmān took the place of [al-Rashīd's] two sons al-Ma'mūn and al-Amīn.'132

Abū Shāma used these historicizations of the post-Golden Age period to argue his main points: exemplary rule could only be envisioned in close relation to the Golden 
Age period, and these periods of ideal rule were clearly delimited from the preceding and following periods. His examples of ideal rulers and Prophets in his pre-Islamic section were limited to those placed in the Muslim teleological perspective of history. Similarly, the examples here continued this perspective into the post-Golden Age period by choosing two ideal individuals who were closely linked to the Golden Age. Thus, the history of his ideal periods presented itself as one of two extended periods (early Golden Age and Șalāh al-Dīn/Nūr al-Dīn), which were supplemented by a limited number of individuals briefly resurrecting ideal rule. These individuals were in turn always attached to the Golden Age period.

Ibn Wāṣil did not establish any link to 'Umar II or Hārūn al-Rashīd. His references to the post-Golden Age period were, again, much more diverse. In the short biography of Șalāh al-Dīn's son, the aforementioned al-Malik al-Af̣̣al 'Alī (a rather unfortunate character among the Ayyubids), he stated that lack of fortune and luck 'was common among virtuous people' (wa-bāadhà huwa al-ghālib fì abl al-fadl). He continued the narrative with a reference to the 'Abbasid 'caliph of one day' Ibn al-Mu'tazz (d. 296/908) who was killed on the very day he was finally appointed caliph - a similarly virtuous individual despised by others throughout his life. ${ }^{133}$

Even more telling is the historicization employed for the Ayyubid ruler of Aleppo, al-Malik al-Nāṣir Yūsuf, who attempted to reinstall the Ayyubid reign in Egypt after the Mamluk al-Malik al-Mu'izz Aybak had taken power. The preparation for the move of the Ayyubid ruler to Egypt was ridden from the outset with disputes and problems. The battle itself in 648/1251 ended with a disastrous defeat for the Ayyubid-Syrian troops. However, most intriguing for Ibn Wāșil was that both armies fought leaderless as their respective leaders had taken flight - each believing defeat to be imminent. He paralleled this with the tragic-comic Battle of the Mills near al-Ramla in 271/885. ${ }^{134}$ In this encounter between central troops from Baghdad and Tulunid Egyptian troops defying caliphal authority, the two leaders ignominiously - also took flight from the battlefield. ${ }^{135}$ Once again he described decisive events at the end of Ayyubid rule as interesting and fascinating, focusing on their bizarre and absurd aspects, rather than announcing a moment of decisive change.

In general, the different kinds of historicization in the narratives of Abū Shāma and Ibn Wāșil have thus to be read as an expression of their modes of emplotment. As well as the narratives' final sections, they reiterated the works' basic themes. In the mode of Process the narrative was open-ended and could refer to a multitude of different historical examples. In the mode of Stasis, on the contrary, the closure was definite and references could only be made to a limited number of examples fitting the narrative's outlook.

Abū Shāma's and Ibn Wāṣil's outlooks raise the question to what degree their stances were unique in the historical works of this period. This question can only be satisfactorily discussed by a detailed consideration of a number of chronicles, which is beyond the scope of this study. However, as an example, the similarities and differences between 'Imād al-Dīn al-Ișfahānī's al-Barq al-Shāmī and Abū Shāma's Rawdatayn can be examined briefly. Although most parts of the Barq are lost, its first 
sections survive in a summary by a Damascene secretary of the early seventh/ thirteenth century, al-Bundārī (d. 643/1245). ${ }^{136}$

'Imād al-Dīn al-Ișfahānī's writings were Abū Shāma's principal sources, especially for the early period covered by the Barq (562/1167 and hereafter). ${ }^{137}$ Abū Shāma's tendency to turn to 'Imād al-Dīn al-Iṣfahānī can be explained by their common perspective. For example, both deplored the situation after the death of Șalāh al-Dīn, to the point that the previously cited line of poetry ('These years and its people elapsed/as if they - the years and the people - had been a dream') was included in both works. ${ }^{138}$ 'Imād al-Dīn al-Ișfahānī's title had already expressed this idea, implying that this period disappeared with the speed of a thunderbolt. The Barq ended sharply with the death of Șalāh al-Dīn, after which 'his sons divided the lands'. ${ }^{139}$ The exemplary period was finished and could only be lamented: 'How quick these nights and days, these months and years ended and perished. ${ }^{140}$

He was also one of the authors who described - like Abū Shāma - the present and the immediate past as a unique period only to be paralleled by the Golden Age. By the sixth/twelfth century a number of authors employed such references to celebrate the momentous present or deplore the catastrophes which had befallen the Muslim lands, especially the Mongol invasions. ${ }^{141}$ A striking example of the former point of view was 'Imād al-Dīn al-Ișfahānī's description of Ṣalāḥ al-Dīn's conquest of Jerusalem as a second hijra. This hijra was even more important than the original one by the Prophet Muhammad, and ought to justify a change of the dating system. ${ }^{142}$

However, 'Imād al-Dīn al-Ișfahānī did not present this break in terms of a complete reversal of a previous pattern of rule. It was a change very much linked to his personal downfall since in the introduction he deplored that his stipends were suspended and his services no longer required, as well as lamenting his isolation in Damascus. ${ }^{143}$ The implication was that a return of 'Imād al-Dīn al-Iṣfahānī would once more bring about such an exemplary period, that is, the present constituted no fundamental break with the recent past. In general, his intention was not to write a biography of Șalāh al-Dīn like Ibn Shaddād's al-Nawādir, or to present two outstanding rulers similar to Abū Shāma's Rawdatayn. Rather his aim was to report the period during which he was in the service of these rulers, ${ }^{144}$ that is, the main focus of the narrative was the person of 'Imād al-Dīn al-Ișfahānī himself. His work consequently had a less rigid outlook than the Rawdatayn - the reappearance of the thunderbolt was closer than the re-enactment of the Two Gardens. Despite the close textual relationship between the Barq and the Rawdatayn, and despite similarities with regard to the title or the vision on the post-Ṣalāh al-Dīn period, Abū Shāma clearly widened the perspective offered by 'Imād al-Dīn al-Iṣfahānī. 


\section{TEXTUAL AGENCY II}

\section{Micro-arrangement, motifs and political thought}

In Chapter 5 we examined Abū Shāma's and Ibn Wāṣil's textual rooms of manoeuvre by considering the modes of emplotment of their narratives. The discussion of 'final section' and 'historicization' showed how the prefiguration of the narratives in the modes of Stasis and Process was crucial for specific textual decisions. In this way the texts are mainly assessed with regard to the levels of inclusion/exclusion and macro-arrangement (the different position of the same reports in the two texts).

This chapter will continue to examine the consequences of the prefigurative choice; however, it shifts the analysis to specific scenes, included in both texts at the same position. The main issues to be approached are micro-arrangement (Abū Shāma) - that is the shaping of the material within a specific report - and the employment of other literary means than arrangement (Ibn Wāṣil). After drawing the different strands of the textual analysis together (Concluding the Textual Analysis: The Pierced Eye and the Lost Ring), the final section of this chapter will offer a broader outlook by setting the results of the analysis in relation to writings in the genre of political thought (Chronicles and Political Thought).

\section{Mode of emplotment applied 3: Abū Shāma's micro-arrangement}

As we saw in Chapter 5, the two authors generally included material from the same sources. One of the intriguing issues when considering the narratives is the different use of their predecessors. Ibn Wāṣil emplotted these sources into a linear narrative endowed with a clear sense of development. He barely cited them verbatim, and rarely mentioned the origin of the pieces of text he included. The reader is thus led through a text characterized by its coherence.

Abū Shāma's narrative, on the other hand, frequently leaves the impression of a fragmented text, where different versions of one single event were included. He cited textual sources verbatim, generally without any explicit intervention, and leaves the bewildered reader with 2, 3 and occasionally 4 competing perspectives of a single event. The fragmented character of the Rawdatayn recalls the khabar style of authors of early centuries such as al-Tabarī, whose works were mainly compilations of previous sources, too. ${ }^{1}$ Just as for those earlier authors, the question arises as to what 
degree the authorial voice can be heard in such a text? ${ }^{2}$ If these works were only repositories of previous texts, what would their distinct characteristics be? The following aims to show that the issue of micro-arrangement is a crucial concept in approaching this question.

The issue of fragmentation has until now not received much scholarly attention with respect to the Rawdatayn. The major study on this work argues that Abu Shāma's decisions on including specific sources were linked to factual concerns: he always chose for inclusion those sources which were nearest in geographical and temporal terms to the events described. ${ }^{3}$ As he tended to cite these extant narrative fragments, Abū Shāma has been generally denied any authorial voice in this work, where he merely 'juxtaposed extracts, which he cites word for word'. ${ }^{4}$

The standard explanation for Abū Shāma's fragmented arrangement is to hint at his immersion in the field of hadith. As much as scholars in this field just enumerated different versions, so Abū Shāma proceeded in this work of history. ${ }^{5}$ However, the fragmented (or compilation-manner) arrangement was not his only approach to historical narratives. In his second main historical work, the Dhayl, one encounters a strikingly different way of structuring the material - the reports follow a strict chronological order without offering several versions of the same event.

Rather than focusing on Abū Shāma's immersion into b̧adīth, I would argue that the fragmentation of the Rawdatayn was the result of a conscious choice about the mode of emplotment. It was neither an unintended by-product of including the most reliable sources, nor the inevitable outcome of his study of badith. The fact that the Rawdatayn and works of hadith were akin in terms of form does not necessarily mean that they were underlain by the same textual strategies.

The fact that the arrangement of his text was based on conscious choices is clear from comments made by Abū Shāma on this issue in the course of his historical narrative. While justifying the inclusion of two nearly identical quotations from different works by 'Imād al-Dīn al-Iṣfahān̄̄, Abū Shāma stated for example:

He mentioned it [first khutba in reconquered Jerusalem] in his work al-Barq in different terms, which contain additional benefits. To repeat the preceding with different terms is beneficial, because they are lofty meanings which are unfolded whenever they are repeated. ${ }^{6}$

(Abū Shāma, Rawḍatayn, III, 381)

Besides factual concerns with accuracy, the fragmented character of his text must also be explained by a concern for the meaning contained within the sources.

In the following discussion I describe the style of arrangement, peculiar to Abu Shāma, as 'circular': the juxtaposition of different parallel reports on the same event was intended to create the impression of circularity. Within the description of an event, the reader was repeatedly led back to the point where he had already previously been without major factual developments. This arrangement reproduced the main idea of his work on a micro level. The description of the period dealt with in the Rawdatayn did not add basic changes to the example set by the early period, as both 
were endowed with the same meaning: the description of one inevitably implied the other.

Ibn Wāșil's style of arrangement, on the contrary, is 'linear'. In general, his scenes progressed clearly from the initial setting via the main events to the conclusion. The narrative closely followed the temporal sequence of events, and avoided repetitions. This went hand in hand with his macro-arrangement where he eschewed ascribing preferences to specific rulers. His narrative was merely a detail of the larger picture of continuously ongoing ideal rule. In this processual mood, repetitions (or circularity) would have been senseless interruptions of the linear course of events he described.

One typical example in Abū Shāma's narrative was the report on Șalāh al-Dīn's advance in 578/1182 to al-Jazīra which ended in the aborted attempt to take Mosul. ${ }^{7}$ His arrangement of this scene was fairly typical, and allows us to clearly see the differences between his and Ibn Wāsilil's narrative, in which the events were described in more brevity. ${ }^{8}$ Șalāh al-Dīn had turned in that year to the east after a short and unsuccessful campaign against the Crusaders in Syria. In the east he planned to include the Artuqid and Zangid territories of al-Jazīra - especially Mosul - in his realms or at least to reduce them to dependent status. He was persuaded to undertake this campaign by the local ruler of Harrān (al-Jazīra), Muẓaffar al-Dīn Gökböri (d. 630/1233), who hoped to weaken or even defeat his Zangid counterparts in Mosul. During the ensuing campaign, a number of places such as al-Bīra and Hisn Kayfa voluntarily recognized Șalāh al-Dīn's supremacy, so that military conquest was the exception. However, Mosul proved to be a more formidable obstacle, which Șalāh al-Dīn only became aware of when seeing the town. Nevertheless, in order to avoid a humiliating retreat a siege was started, but the troops had to leave the town without any success after only one month. Abū Shāma and Ibn Wāṣil arranged their respective passages as shown in Table 1.

Ibn Wāṣil's account of the campaign followed a clear chronological development, with Șalāh al-Dīn moving via northern Syria to al-Jazīra, taking the minor places, and culminating in the siege of Mosul. Although Abū Shāma's narrative had roughly the same outline, he repeatedly returned to previously described stages in the course of the text. By including mostly verbatim passages from 'Imād al-Dīn al-Ișfahānī (nos 1, 2, 3, 8, 9, 11, 12), Ibn Shaddād (nos 4, 13), Ibn Abī Ṭayy (no. 5) and letters by al-Qāḍ̄ al-Fādil (nos 6, 7, 10), he created a fragmented text constantly breaking the impression of linearity. For example, the passage on Muẓaffar al-Dīn Gökböri’s role in convincing Șalāh al-Dīn to move to the east was repeatedly mentioned - the fourth and final time was even after the focus of the text had already moved well to the eastern lands (no. 8). Certainly, each passage added some new items, but the majority of the material repeats information included in the previous reports. The extensive letter to the caliph (no. 10) reinforced the impression of circularity. This letter added hardly any information and was - from a factual point of view - a repetition of events reported previously in more literary terms.

Nos 1 and 3 in Abū Shāma's text introduced the scene and were roughly identical to Ibn Wāṣil's no. 1. However, the sandwiched panegyric poetry, exclusive to Abū Shāma, 
Table 1 Arrangement 'Campaign to Mosul'

\begin{tabular}{|c|c|c|c|c|}
\hline No & Abū Shāma & Words & Ibn Wāṣil & Words \\
\hline & $\begin{array}{l}\text { Chapter on the sultan moving a } \\
\text { second time to the eastern land }\end{array}$ & & $\begin{array}{l}\text { Report on the sultan moving } \\
\text { to the eastern lands }\end{array}$ & \\
\hline 1 & S. moving to northern Syria & 96 & Ș. moving to $\mathrm{n}$. Syria + M. & 152 \\
\hline 2 & Panegyric for Ș. & 174 & $\begin{array}{l}\text { Siege of al-Bīra } \\
\text { Report on the sultan taking } \\
\text { possession of al-Jazīra }\end{array}$ & 217 \\
\hline 3 & M. I & 57 & Expansion in east & 124 \\
\hline 4 & M. II + S. crosses Euphrates I & 75 & $\begin{array}{l}\text { News of Crusaders } \\
\text { attacking Damascus }\end{array}$ & 79 \\
\hline 5 & M. III + Ș. crosses Euphrates II & 197 & & \\
\hline 6 & $\begin{array}{l}\text { Expansion in east (Letter to Ṣ.’s } \\
\text { nephew Farrukhshāh) }\end{array}$ & 51 & & \\
\hline 7 & $\begin{array}{l}\text { Expansion in east (Letter to Ṣ.'s } \\
\text { brother al-'ĀAdil) }\end{array}$ & 42 & & \\
\hline 8 & M. IV & 59 & & \\
\hline 9 & Ș. crosses Euphrates III & 38 & & \\
\hline \multirow[t]{2}{*}{10} & $\begin{array}{l}\text { Description of campaign (Letter to } \\
\text { caliph) }\end{array}$ & 1175 & & \\
\hline & Chapter & & & \\
\hline 11 & Expansion in east & 148 & $\begin{array}{l}\text { Report on the sultan al-Malik } \\
\text { al-Nāsir besieging Mosul }\end{array}$ & \\
\hline 12 & Siege of Mosul & 115 & Siege of Mosul & 469 \\
\hline \multirow[t]{2}{*}{13} & Missions for truce + end of siege & 117 & $\begin{array}{l}\text { Missions for truce }+ \\
\text { end of siege }\end{array}$ & 265 \\
\hline & Total words: ${ }^{\mathrm{a}}$ & 2344 & & 1306 \\
\hline
\end{tabular}

Notes

Ș. Șalāḥ al-Dīn;

M. Muzaffar al-Dīn Gökböri convincing Ș. to move to al-Jazīra;

a The guiding principle in my method of counting is that each unit written independently is counted as a 'word'. For example, inseparable prepositions, conjunctions and other prefixes, such as 'wa-' and 'bi-' are not counted, while units such as ' $a w$ ' and ' $l \vec{a}$ ' are counted. Chapter headings are included. In the case of differences between manuscripts the longer version has been taken into account.

extended the horizon beyond immediate events. After a classical nasīb introduction mourning the loss of the beloved, Șalāh al-Dīn was referred to as 'Yūsuf'. Ibn Wāṣil did not employ this historicization at this point, which placed Șalāh al-Dīn within the larger Islamic history and singled him out from other contemporary rulers. The starting point for this scene consequently differed strongly between the two narratives: normal expansion to the east by a specific ruler versus a further stage of development within the long-lasting history of the Islamic community.

Abū Shāma's nos 4, 5 and 8 repeated his no. 3 with minor rephrasing and some new information. Unlike the previous poetry and the following letters, these passages did not contain important additional layers of meaning, but it was in such passages that the 'badīth approach' mentioned here probably played a role in the composition. The reader gains the impression that the author had no interest in judging and evaluating the various, and sometimes contradictory, man-made reports. 
Nos 6 and 7, exclusive to Abū Shāma, were short extracts from letters by Șalāḥ al-Dīn’s secretary al-Qāọ̄i al-Fāḍil to the sultan's nephew Farrukhshāh in Damascus, and the sultan's brother al-'Âdil in Egypt. Both letters stressed the need for financial assistance for the expansion, since the expenses of the campaign did not suffice to satisfy the army's demands: 'We came to a sea, which only a sea can stop.' ond use of 'sea' referred to Șalāh al-Dīn's generosity, which was one of the important characteristics stressed by his panegyrics. Closely linked to asceticism, stories such as his not leaving any heritage for his descendants became crucially important to his image in posterity. Thus, the inclusion of the letters introduced one specific characteristic of ideal rule and made the abstract preceding reference to the Islamized ancient history (Prophet Yūsuf) more palpable. In no. 9 (repeating, factually, the crossing of the Euphrates stated in no. 5) this metaphor was taken up: 'The sea [i.e. Șalāh al-Dīn] came to the Euphrates. ${ }^{, 10}$ Regarding the fact that this passage was both very brief, and dealt with an event already discussed, it seems that the repetition of this crucial characteristic of ideal rule induced Abū Shāma to include it.

The following letter to the caliph constituted roughly one half of the report under discussion. ${ }^{11}$ Its function was to recall Șalāh al-Dīn's great deeds for the present campaign and, more importantly, to depict him as the defender and servant of the caliph. Written shortly after the crossing of the Euphrates it asked first for guidance in the current campaign, and then recalled the fall of the Fatimid dynasty and the reconstitution of the 'Abbasid nominal sovereignty under Șalạ al-Dīn in Egypt. This absence and return of the 'Abbasid khutba was then equated, in line with the self-perception of the period, with the hijra of the Prophet Muhammad. ${ }^{12}$

The campaign to the east bridged not only the temporal gap between Șalāh al-Dīn and the early Islamic period, but also geographical distances. By undertaking the campaign he moved closer to the caliph's residence 'Dār al-Salām', that is Baghdad ${ }^{13}$ a term with connotations of the celestial garden. Here we have an example where the two main connotations of the work's title (ideal rule and similarity of the early Golden Age with the reigns of Nūr al-Dīn/Șalāh al-Dīn) unfolded: the reference to the garden as metaphor for ideal rule was paralleled by the dual reference to the hijra now and then. The link to the early Islamic period was continued by describing Șalāh al-Dīn's men, those professing the Oneness of God (muwaḅhidūn), as being juxtaposed to the Mosulians who were allied with the unbelieving Crusaders. ${ }^{14}$ This latter unholy alliance was described with a Quranic citation. ${ }^{15}$ Șalāh al-Dīn was presented as the guardian of the Islamic community (ummat al-nabi) and the protector of the caliphate, a passage ending with another Quranic citation. ${ }^{16}$

None of these letters or repetitive reports can be found in Ibn Wāṣil's text, which, after the initial setting in no. 1, continued with a detailed description of the situation at al-B̄ira. He discussed the events of the previous years by focusing on the complicated inter-Artuqid disputes concerning the town. This section had no parallel in Abū Shāma, who referred only briefly to the town's submission. This interest in events linked to minor places was a general characteristic for Ibn Wāșil, whose focus on the respective central ruler was less emphasized than in Abū Shāma. A typical element in Ibn Wạșil's narrative was the following-up of the succession of rulers of a specific 
town or castle up to his own day. In addition to presenting this information for major (Aleppo) ${ }^{17}$ and lesser places (Homs), ${ }^{18}$ he also included the succession of lords at minor castles such as Șahyūn. ${ }^{19}$ Abū Shāma, though, had no comparable passage in the entirety of his work, which focused on the central rulers Nūr al-Dīn and Șalāh al-Dīn. Lesser rulers were of minor significance to him, so pursuing the history of their reigns beyond the temporal (or rather moral) boundaries set by the Rawdatayn would have made no sense to him.

Ibn Wāṣil's no. 3 on the expansion in al-Jazīra was paralleled by Abū Shāma's nos. 5 and 11. His no. 4 on the Crusaders attacking Damascus was exclusive to him. With the following no. 12 we reach the focal point of Ibn Wāșil's composition: the siege of Mosul, which had in the preceding text been described as the aim of the whole campaign, and the following missions (no. 13). Concomitantly, the description of these events took up more than half of the narrative of the entire scene, whereas Abū Shāma's description of these events took only a tenth of it. Abū Shāma's lack of interest in this factual description is striking, when compared to the letter to the caliph, which was 'only' aimed at legitimating his campaign. The importance of the events during the siege seemed themselves rather negligible to him.

Ibn Wāṣil's narrative in the entire scene was vivid and once again displayed a tendency to include details which bordered on comedy and irony. Having arrived at the town, Șalāh al-Dīn started the symbolic siege. In the ensuing fight the commoners of the town took advantage of a sortie to throw a sandal pierced with nails at one of Șalāh al-Dīn's officers, Jāwalī al-Asadī. The officer turned to Șalāh al-Dīn complaining of the 'stupidities' used by the Mosulians in the fight and finally 'threw down the sandal and took an oath that, for his pride, he would not resume fighting where one is hit by sandals' ${ }^{20}$

This scene with the officer leaving the field after the footgear attack ended the description of the fighting at Mosul. The scene thus came to a rather undramatic and banal conclusion, which recalled Ibn Wāșil's penchant for the bizarre and absurd sides of conflicts. Abū Shāma excluded this anecdote since such an inglorious end to the siege was probably not sufficient for the protagonists of the Rawdatayn. It once again shows that Ibn Wāṣil was rather uninterested in depicting Ṣalāh al-Dīn as fighting within a larger framework of ideal rule and in continuity of early Islamic history.

Both authors concluded the scene with a section on missions from Mosul to the caliph in Baghdad and to the eastern Eldigüzid ruler Pahlawān Muhammad (d. 582/1186) seeking support against Șalāh al-Dīn's campaign. The main difference between the otherwise largely similar narratives is in the description of the failed negotiations initiated by the caliph: Ibn Wāṣil treated it with much detail, whereas Abū Shāma alluded only incidentally to this unsatisfying outcome of discussions conducted under the patronage of his symbol for a united umma.

In the preceding discussion of the micro-arrangement, Abū Shāma's fragmentation (i.e. the inclusion of different perspectives on one event with hardly any additional factual information) appeared in two different contexts. First, these repetitive passages occurred, as seen with regard to nos 4, 5, 8 and 11, as a variety of perspectives not offering substantial layers of meaning. These passages need not concern us too much in the framework of this study; however, they are an important reminder 
that the approach chosen here for reading the narratives is not the only possible way to understand the texts.

In a second context, fragmentation occurred in parts, such as letters 6,7 and 10, which also treated the same event, and which hardly added any information, but which were endowed with important layers of meaning. While these appear to be superficially similar to the other fragmented passages, their main function was to produce a 'morally linear' narrative. Their linearity was crucial in reworking the underlying theme of the work as prefigured by the mode of Stasis.

When we consider either chronicles written on the Ayyubid/Zangid rule or universal chronicles written during that period, it appears that Abū Shāma's fragmented arrangement was peculiar to him. Taking the example of the Mosul scene, authors such as Ibn Shaddād, Ibn al-Athīr or 'Imād al-Dīn al-Iṣfahānī arranged their material in a strictly linear fashion. ${ }^{21}$ At this time, Ibn Wāsil's factually linear narrative was the dominant method in the region. In contrast to Abū Shāma, Ibn Wāṣil's vision of ideal rule (which was arguably similar to the visions of the other authors adhering to such a linear narrative), was more mundane, and largely in harmony with his surrounding society. This meant that Ibn Wāṣil perceived the moral lesson taught in his work to be implicit in the unfolding of the factual narrative itself. He could offer a linear narrative in factual and moral terms since the present itself was the ideal. Aiming at dissipating anxieties, he told his story as a continuous stream of events without decisive breaks. He underlined the equality of the distant past, immediate past, and present both by continuing his narrative well into the periods contemporary with him and also through his constant references to following events, such as the sequence of rulers. The difference between fragmentation in Abū Shāma's text on the one hand and linearity in Ibn Wāṣil's and other authors' texts on the other reaffirm the differences worked out with regard to their historical corpora in Chapter 2.

The ironic tendency in Ibn Wạșil (see earlier) was closely linked to the narrative's outlook. As Ibn Wāṣil had less need to advance a vision of past and present in opposition to the current state of affairs, he had no cause to advance his vision in Abu Shāma's emphatic style. He could focus on the entertaining aspects without endangering his narrative's meaning. In the mode of Process, it was possible to dispense with the grand ideas advanced by Abū Shāma. Ibn Wāṣil even included poetry by the Damascene poet Ibn al-'Unayn (d. 630/1233), ${ }^{22}$ who was renowned for his satire on, and mockery of, the important individuals under Șalāh al-Dīn's rule (the poet's satire on the ruler himself finally earned him banishment from the town). Abū Shāma, in contrast, did not include into his work a single line of this author who subjected one of his two exemplary dawlas to ridicule, although he generally cited far more extensive sections of poetry. ${ }^{23}$

\section{Mode of emplotment applied 4: motifs in Ibn Wāșil's narrative}

However, Ibn Wāṣil's narrative is not as unproblematic as it might seem from the previous section. Although less in need of advancing his vision of society with the 
emphasis characteristic of Abū Shāma, he had recourse to different literary means in order to present his version. Integrating his sources into one coherent narrative, the question of arrangement was less salient than in Abū Shāma's text. While one of Abū Shāma's main tasks was to arrange the reports in ways peculiar to him, Ibn Wāșil was less occupied by this question as verbatim citations of previous sources were rare in his text.

The most salient feature in Ibn Wāșil's narrative was the employment of other literary means than 'arrangement' in changing the intensity of various scenes. Sometimes characterized by a distanced and sober style, the narrative occasionally turned more vivid and complex with the use of means such as direct speech with shifts between first and third person, poetry and motifs. As in Abū Shāma, such passages alternated with standard factual ones; the Mosul scene discussed earlier, for instance, was of no particular significance within Ibn Wāsil's work. While it was entertaining, compared to the following scenes, it was characterized by the low number of literary means employed.

The fact that Ibn Wāșil was able to employ such means must be seen in relation to his choice of his mode of emplotment: it was the linear narrative characteristic of the mode of Process, which allowed Ibn Wāsil to introduce literary means in a controlled manner. In Abū Shāma's text though, the occurrence of such literary elements was often uncontrolled owing to his style of including whole passages from preceding works. This style allowed him to create the impression of fragmentation crucial to the mode of Stasis. However, it meant losing authorial control over an issue such as the employment of motifs. Therefore, a comparative analysis with Abū Shāma is certainly helpful, but does not by itself yield sufficient results. The meaning of these elements has to be deduced from an internal analysis of Ibn Wāṣil's text.

While most elements discussed in the following section do not need any comment, the use of the term 'motif' does. Motif is understood here as a narrative element appearing in different scenes. Although it might differ in its factual function and the factual environment in which it is placed, a specific meaning unites the element's role in these scenes and renders it a motif. 'Motif' shows a certain commonality with the concept of 'topos' as employed by Noth/Conrad (1994). However, their main interest in topoi is whether or not the recurring motif had a factual basis. Here, on the contrary, the main question focuses on the meaning peculiar to a specific motif occurring in different instances. In the following, the 'arrow' motif will exemplify the concept's main idea.

As mentioned earlier, one of the salient features in Ibn Wāșil's narrative in factual terms was the important role played by regional rulers. This issue is taken up in the following section by discussing the example of the attack on the castle Ja'bar by 'Imād al-Dīn Zankī, Nūr al-Dīn's father. ${ }^{24}$ Taking place in 541/1146, two years after 'Imād al-Dīn Zankī took Edessa from the Crusaders, it was the increasing development of centralized rule in al-Jazīra and Syria which was at stake.

After the siege of castle Ja'bar had started, 'Imād al-Dīn Zankī sent one of his amirs (called either Hassān or Ibn Hassān, depending on the version) to the castle's lord, Mālik al-'Uqaylī, for negotiations. Mālik refused any offer of surrender under 
safe-conduct despite 'Imād al-Dīn Zankī's overwhelming superiority. In reply to the envoy's insistence, Mālik stated that he was waiting for an event similar to the one which had rescued (Ibn) Hassān's father from a comparable situation some three decades earlier: besieged in Manbij, (Ibn) Hassān's home town north-east of Aleppo, only the miraculous death of the besieger Balak by a stray arrow had prevented imminent defeat. Left speechless by such a story referring to his own father, (Ibn) Hassān returned to his master's camp without any result. During the following night 'Imād al-Dīn Zankī was killed by his own servants, which miraculously rescued Mālik from his desperate situation. Because the focus will be on a variety of literary means, the main parts of this scene will first be translated and then analysed (Table 2).

Table 2 Translation 'Siege of Castle Ja'bar'

\begin{tabular}{|c|c|}
\hline Ibn Wāṣil & Abū Shāma \\
\hline $\begin{array}{l}\text { [No. 1] } \\
\text { Report on 'Imād al-Dīn attacking } \\
\text { castle Ja'bar. } \\
\text { We had mentioned that the sultan } \\
\text { Jalāl al-Dawla Malikshāh, when he } \\
\text { took over Aleppo, compensated its } \\
\text { lord, Sālim b. Mālik b. Badrān } \\
\text { al-'Uqaylī [...], with castle Ja'bar, } \\
\text { which he had taken over previously } \\
\text { (as it was mentioned before). Thus, } \\
\text { Sālim b. Mālik took over castle } \\
\text { Ja'bar and it remained in his and } \\
\text { his son's possession. In the year } 541 \\
\text { 'Imād al-Dīn moved to castle } \\
\text { Ja'bar - the lord of which was } \\
\text { Mālik b. Sālim b. Mālik b. } \\
\text { Badr al-'Uqaylī̄a - and besieged it. } \\
\text { He sent a troop to castle Fanak } \\
\text { [Finīk] to besiege it. Its lord was at } \\
\text { that time the amir Husām al-Dīn } \\
\text { al-Kurdī al-Bashnawī. It had been in } \\
\text { the possession of the Bashnawīds } \\
\text { for over } 300 \text { years. 'Imād al-Dīn } \\
\text { intended - with excessive firmness } \\
\text { and precaution - not to leave a castle } \\
\text { in his lands, which was located in the } \\
\text { middle of his realms, except that he } \\
\text { took possession of it. }\end{array}$ & $\begin{array}{l}\text { TNo. 1] } \\
\text { The death of ['Imād al-Dīn] Zankī } \\
\text { (May God have mercy on him) } \\
\text { Ibn al-Athīr reported: The sultan } \\
\text { Malikshāh had handed castle } \\
\text { Ja'bar to the amir Sālim b. Mālik } \\
\text { al-'Uqaylì when Qasim al-Dawla } \\
\text { ['Imād al-Dīn's father] took } \\
\text { possession of Aleppo. It remained in } \\
\text { his and his sons' hands until the } \\
\text { year [5]41. Then the martyr ['Imād } \\
\text { al-Dīn] moved to it and besieged it. } \\
\text { The reason for his besieging it and } \\
\text { besieging the town of Fanak [Finīk] } \\
\text { was that nothing should remain in } \\
\text { his lands, however insignificant it } \\
\text { might be, that was not in his hands. } \\
\text { This, due to his firmness and } \\
\text { precaution. } \\
\text { [No. } 2 \text { ] } \\
\text { He stayed there besieging it } \\
\text { personally until five nights had } \\
\text { passed of the month of Rabī' } \\
\text { [al-Ākhir]. While he was sleeping } \\
\text { a group of his slaves seized and } \\
\text { assassinated him without delivering } \\
\text { the final blow. They took advantage } \\
\text { of the night to flee to the castle while } \\
\text { his companions were not aware of } \\
\text { his assassination. When this group } \\
\text { had ascended to the castle, those in } \\
\text { it shouted to the [besieging] troops } \\
\text { letting them know about his }\end{array}$ \\
\hline
\end{tabular}


Ibn Wāsil

an envoy to its [the castle's] lord due to the friendship between them regarding its surrender. He ['Imād al-Dīn] told him [Hassān]:

'Guarantee him a large $i q t \bar{c}$ ' and an ample sum of money in the case that he agrees to surrender. Otherwise tell him: "By God, we will stay until we take it by force and I will not leave [anything] for you. Who protects you from me?"' Hassān ascended to the castle and conveyed 'Imād al-Dīn's message to him [Mālik al-'Uqaylīi]. He promised him compensation for it and made him desirous [for the offer]. However, he [Mālik al'Uqaylī] refused and Hassān replied: 'He tells you: "Who protects you from me?" ' He [Mālik al'Uqaylī] replied: 'I will be protected from him by what protected you from Balak.' He referred to Balak b.

Bahrām b. Artuq's [d. 518/1124] attack on Manbij after he had imprisoned its lord Hassān. When only its fall remained, a stray arrow hit Balak in his throat and killed him so that Hassān was saved from him. The battle of 'Imād al-Dīn was similar to the battle of Balak. Who deems himself to be superior to God may he be exalted - [God] proves him a liar. In a saying on the authority of God - may he be exalted [it is stated:] 'I am God, the lord of Mecca, I did not fulfill anything [any wish] for somebody who commits foul/impure actions.' Hassān returned to 'Imād al-Dīn and informed him about his [Mālik al-'Uqaylī's] refusal [to surrender] but he did not mention the story of Balak.

[No. 3]

Report on the death of the martyr 'Imād al-Dìn Atābak Zankī $b$. $\bar{A}$ qsunqur (God have mercy on him)
Abū Shāma

assassination. His companions hurried to him. The first of them reached him and he was still alive, then God sealed his deeds with his martyrdom: 'He met the fate and I was not aware/that the fate will be inflicted by the beloved ones.'

[No. 3]

So it came about: hope had betrayed him, the appointed time of his term had grasped him, and servants and slaves had abandoned him. What a star of Islam set, what a protector of faith left, what a magnanimous sea dried up, what a moon of nobilities disappeared, what a lion was killed! Neither the highest point of a fortress nor the back of a horse rescued him. How much did he exert himself to smooth the rule and its governance [siyassa]; how much did he refine it [siyāsa] by guarding and protecting it [rule]. The destroyer of the peoples and their annihilator in youth and age came to him, he subdued him after he had subjected the creatures. He made him forgiven and buried in the sand, after the comfortable resting-places [had been his home]. Held in a grave where nothing is of benefit except of what he had done previously. The page of his deeds was turned over and he is bound in submission. Then he was buried in Siffin close to the companions of the Commander of the Faithful [the Fourth Caliph] 'Alī (God be pleased with him).

[No. 4]

I said: al-'Imād al-Kātib mentioned in his work al-Saljūqūya: Zankī planned to besiege castle Ja'bar, so he encamped there. Whenever he slept several of his servants slept around him, whom he liked and they 


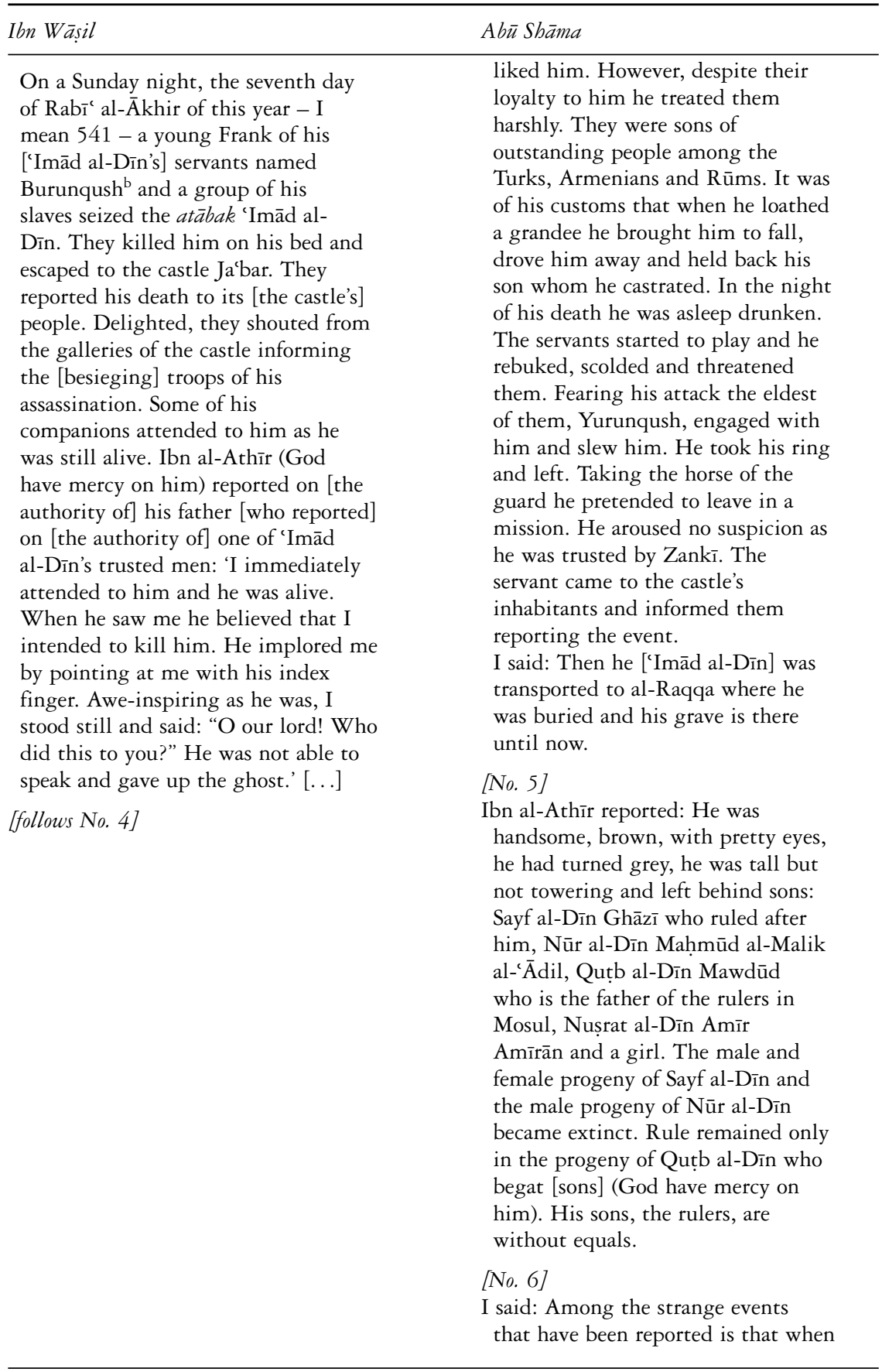


Table 2 Continued

\begin{tabular}{|c|c|}
\hline Ibn Wāssil & Abū Shāma \\
\hline & $\begin{array}{l}\text { the siege of castle Ja'bar } \\
\text { intensified, Ibn Hassān al-Manbijī } \\
\text { came at night and took his stand } \\
\text { below the castle. He called its lord } \\
\text { who responded. He told him: 'This } \\
\text { lord, the atābak, is the owner of the } \\
\text { lands. He came upon you with the } \\
\text { armies of this world. You are devoid } \\
\text { of protection and supporter. I think } \\
\text { that I should mediate in your affair } \\
\text { and take from the lord, the atābak, a } \\
\text { locality as compensation for this } \\
\text { locality. If you do not do this, what } \\
\text { are you waiting for, then?' The lord } \\
\text { of the castle told him: 'I wait for what } \\
\text { your father awaited!' The lord of } \\
\text { Aleppo, Balak b. Bahrām, had } \\
\text { attacked his father Hassān and } \\
\text { besieged him in Manbij with } \\
\text { intensity. He brought several } \\
\text { catapults into position. One day, } \\
\text { after he had caused destruction by } \\
\text { fire with a catapult stone, he said to } \\
\text { Hassān: 'What are you waiting for to } \\
\text { surrender the castle?' Hassān replied } \\
\text { to him: 'I am waiting for an arrow of } \\
\text { the arrows of God!' On the following } \\
\text { day, while Balak was arranging the } \\
\text { catapults, a stray arrow hit him in the } \\
\text { upper part of the chest. He sank down to } \\
\text { the ground as a dead man. No part of his } \\
\text { body was exposed except that part as he did } \\
\text { not close the amour he wore on his chest. } \\
\text { When Ibn Hassān heard this speech } \\
\text { of the lord of Ja'bar he turned from } \\
\text { him. In that night the atābak was } \\
\text { killed. This was among the strange } \\
\text { coincidences and the unusual } \\
\text { lessons. Yahyā b. Abī Tayy } \\
\text { mentioned this in his work al-Sīra } \\
\text { al-Salābīya. } \\
\text { [follow Nos } 7 \text { and } 8 \text { ] }\end{array}$ \\
\hline
\end{tabular}

Notes

a Correct version would be Mālik b. 'Alī b. Sālim b. Mālik b. Badrān al-'Uqaylī.

b Meant is possibly 'Yurunqush'. 
Table 3 Arrangement 'Siege of Castle Ja'bar'

\begin{tabular}{llrlr}
\hline No & Ibn Wạsil & Words & Abū Shāma & Words \\
\hline 1 & Setting/Introduction to scene & 117 & Setting/Introduction to scene & 63 \\
2 & Mission to Ja'bar & 156 & Killing of 'Imād al-Dīn I & 68 \\
3 & Killing of 'Imād al-Dīn & 135 & Praise of 'Imād al-Dīn & 93 \\
4 & Biography of 'Imād al-Dīn & 1092 & Killing of 'Imād al-Dīn II & 109 \\
5 & & & Short biography + his children & 72 \\
6 & & Mission to Ja'bar + Killing III & 129 \\
7 & & Biography of 'Imād al-Dīn & 1277 \\
8 & & & Poetry with some prose & 629 \\
& Total words: & & & 2440 \\
\hline
\end{tabular}

Ibn Wāṣil and Abū Shāma structured their narrative as shown in Table 3. Ibn Wāsil followed his linear structure, setting the reports in a sequence of introductory passage, the following dialogue between Ibn Hassān and Mālik and the culmination with 'Imād al-Dīn Zankī's death. In contrast, Abū Shāma's version of this scene was characterized by the typical fragmented narrative. The introductory passage was immediately followed by the first version of 'Imād al-Dīn Zankī's death. The subsequent one, praising the ruler, gave way to a second, slightly more detailed, version of his death. Surprisingly, the start of his biography which followed was quickly interrupted in order to introduce the dialogue between Ibn Hassān and Mālik, culminating once again in the death of the ruler. ${ }^{25}$ Both authors ended their scene with a biography of 'Imād al-Dīn Zankī, followed in Abū Shāma by laudatory poetry. I will only be using these biographies as a supplement to the main concern here: the analysis of 'Imād al-Dīn Zankī's death scene in Ibn Wāṣil.

Ibn Wāṣil and Abū Shāma both explicitly and implicitly criticized 'Imād al-Dīn Zankī in their texts. Like previous authors, as well as his positive qualities such as military skills, they included elements depicting him as a despot who spread terror and fear. ${ }^{26}$ Compared with other rulers he was more often subject to censure, which was not generally a common practice among the chroniclers of the period. The negative elements of his image were propagated by stories such as 'Imād al-Dīn Zankī sending one of his amirs to a local deputy who had illicit contacts with the wives of men serving in 'Imād al-Dīn Zankī's troops. He ordered the amir to castrate the deputy and gouge his eyes' out for his specific deeds, and crucify him as general punishment. The order was duly carried out. ${ }^{27}$

However, 'Imād al-Dīn Zankī was not unequivocally seen as a tyrant - Ibn Wāṣil and Abū Shāma did not tend to construct simple dichotomous categories where rulers were exclusively depicted either positively or negatively. Such a simplistic classification was only used for minor local rulers who were described in short sections. What is of relevance here is that the two authors differed in the elements which they considered crucial for evaluating his rule positively or negatively.

For example, in his text Abū Shāma included 'Imād al-Dīn Zankī's disloyalty towards the caliph al-Manșūr al-Rāshid (r. 529/1135-530/1136) who sought refuge with him in 
Mosul from the Saljuq sultans' attacks. Under pressure from the Saljuqs, 'Imād al-Dīn Zankī exiled the caliph, who was finally murdered in Persia. ${ }^{28}$ This scene must be read in conjunction with the importance Abū Shāma attached to the caliphate, as is apparent from the salient narrative elements used in reports linked to this institution.

In Abū Shāma's text, the caliphate was the only instance of a governing institution where a list of rulers up to the author's own period was presented ${ }^{29}-$ as shown earlier, one of the elements used by Ibn Wāșil for a wide variety of ruling houses. Similarly, the death of a caliph was the only occasion where obituary notices clearly broke the work's annalistic structure. A block of minor obituary notices, referring mostly to religious scholars, often accompanied the central caliphal obituary notice. Such blocks did not mention those scholars who had died in the same year, which is what might have been expected, given the work's annalistic structure. Instead they detailed scholars who had died during the years of the caliphal reign. ${ }^{30}$ Finally, the respective caliph in Baghdad was the addressee of letters legitimating the sultans' actions in Syria and Egypt. While Abū Shāma included such letters extensively - see the Mosul episode, earlier - they played a significantly less important role in Ibn Wāṣil's text. Thus, given the importance Abū Shāma ascribed to the caliphate, the scene amounted to a severe criticism of 'Imād al-Dīn Zankī's behaviour in the case of al-Rāshid.

Among the positive elements that Abū Shāma included for 'Imād al-Dīn Zankī was his fight against the Crusaders. Descriptions such as the one of his conquest of Edessa were accompanied by miracles and dreams of different sorts: a religious scholar in Sicily was aware of the conquest before the news spread, and 'Imād al-Dīn Zankī was seen after his death stating that God had forgiven him by reason of his conquest of Edessa. ${ }^{31}$ Another positive element was the conquest of Muslim territories under control of local rulers. His conquests of minor and major places were never subject to criticism or doubt regarding his intention. Rather Abū Shāma accepted that these conquests were part of his jihād against the Crusaders.

For Ibn Wāsil, the relationship to the caliphate or the fight against the Crusaders did not have the same importance. Indeed, miraculous events happened during minor affairs such as the conquest of Jazīrat Ibn 'Umar. ${ }^{32}$ It was only the providential surrender of the town, which rescued 'Imād al-Dīn Zankī and his men from certain death owing to the river's sudden rise during the following night. ${ }^{33}$ More often, however, scenes with a local focus appeared in the context of criticism directed against the ruler, for instance his treachery in order to take Hama, and his torture and crucifixion of the troops of Baalbek after having agreed on safe conduct. ${ }^{34}$ The author added to the scene at Hama, his home town, the indignant comment, 'there is no thing more vile than treachery'. ${ }^{35}$

Ibn Wāṣil's penchant for minor rulers striving for survival in periods of centralizing rule is not only visible from the succession list of rulers of rather insignificant places mentioned earlier. The importance of this characteristic is, for example, also clear from reports on his short-term patron al-Malik al-Nāṣir Dā'ūd (d. 657/1259), a rather tragic figure who spent his life as ruler of marginal places such as al-Karak, striving to regain sovereignty over Damascus. Having inherited Damascus from his father, he had to surrender it after less than two years to his besieging uncle al-Malik al-Ashraf 
Mūsā (d. 635/1237). All his subsequent attempts to regain the town were in vain, as he was regularly on the losing coalition's side within Ayyubid politics. Obliged to hand his possession of al-Karak over to a son in 647/1249-50, he lost his wealth when the caliph refused to hand back the valuables which he had deposited at the caliph's court. He spent the last years of his life seeking refuge in Syrian towns, being repeatedly arrested, spending periods with Bedouins and finally dying of plague in a village near Damascus.

Ibn Wāṣil continuously included reports on him in his text, generally displaying sympathy for this unfortunate man. Al-Nāṣir was one of the rulers in Ibn Wāṣil's narrative who was set in a historical perspective with regard to the early Islamic period. Ibn Wāṣil extensively cited al-Nāṣir's poetry to the caliph written from Karbalä, ${ }^{36}$ reported his reference to the period of the caliph 'Umar, and included a dream from his last days when the Prophet Muhammad and the legendary figure Khị̣r visited him. ${ }^{37}$ This positive stance cannot be explained merely by al-Nāṣir's former patronage of Ibn Wāṣil. Al-Șāilị Ayyūb was a much more important patron, over a longer period. Nevertheless, Ibn Wāṣil sided - in his text - with al-Nāṣir when al-Ṣālih attempted to extend his sovereignty from Egypt to al-Karak and the surrounding regions. He not only quoted at length the poem addressed by al-Nāṣir to al-Ṣālih, in which the latter was scolded for his campaign, but also summarized the poem to ensure that the meaning was understood. ${ }^{38}$ al-Nāṣir had Ibn Wāṣil's sympathy as he strove to survive against the respective central ruler.

In contrast, Abū Shāma had no such penchant for local rulers, his focus being on the central rule. It was earlier shown how the crucial importance he attached to the caliphate was expressed by including outstanding narrative elements. This also became evident in his introduction where he enumerated the reports he had studied and which had induced him to compose this work. In addition to Prophets, Companions, Followers, jurisprudents, virtuous individuals and poets he mentioned only 'caliphs and sultans' as categories of the ruling elite. ${ }^{39}$ Other categories such as maliks or amirs were absent from his list, as he seemingly considered them to be of no crucial relevance.

In general, Abū Shāma tended to put local rulers, maliks, into a negative light, while Ibn Wāṣil considered them, with regard to the issue of legitimacy, to be of equal footing with the sultans. Abū Shāma described the 'maliks' of the pre-Nūr al-Dīn period as belonging to the jābilīya ${ }^{40}$ contrasted the 'maliks' of his period with the same exemplary ruler, ${ }^{41}$ and described a Crusader-Muslim coalition with the general terms 'the maliks and the Franks' ${ }^{42}$ Ibn Wạșil, on the contrary, praised the Ayyubids as the 'maliks of the earth' ${ }^{43}$ and praised Nūr al-Dīn for bestowing upon a local ruler 'what is appropriate to be offered to maliks'. ${ }^{44}$

This difference with regard to the issues of regional and central rule touched upon one of the central issues in the Ayyubid period. From the point of view of the Ayyubid rulers, partition of power was the norm, not the exception. The domination of a single member of the dynasty in the Syrian and Egyptian lands was, under the Saljuq mode of rule, considered to be an anomaly. Ibn Wāșil adhered to this vision in his text, and extended it to other periods. Abū Shāma rejected this view, and tried to position Nūr al-Dīn and Ṣalāh al-Dīn as examples of ideal rulers who achieved 
unity in their lands. In the mode of Stasis the crucial issue was the morality of the rulers, that is to what degree they conform to criteria of ideal rule. In the mode of Process on the contrary, the issue of the rulers' morality was generally sidelined by assuming that no significant differences existed between the main protagonists in this regard. The main issue in the mode of Process, as chosen by Ibn Wāșil, was the opposition between central and local rulers.

Ibn Wāșil's stance must also be seen in the context of his social position, that is his integration into elite networks in Syria and Egypt. The fact that he focused to some extent on minor rulers and even amirs who held minor places or castles was also an outcome of his close interaction with such individuals. His implicit approach 'The King is dead! Long live all the Rulers - whoever they may be!' fitted the outlook of individuals striving for a more important role.

Keeping this different evaluation of central and local rule in mind, the Ja'bar scene took on quite different meanings in the two texts. For Ibn Wāșil it was the culmination of a centralizing campaign, which he viewed with distrust, while, for Abu Shāma, Ja'bar signified the fate of those rulers led astray from ideal rule. Ibn Wāṣil undermined the ruler's right to attack in three ways. He stressed that Ja'bar, as well as the neighbouring Castle Fanak (which had been attacked at the same time), had for a long time both been in the hands of their respective lords. 'Imād's attack on the castles was then described as a result of his 'excessive [zeal]' (mubälagha) not to leave a single castle in his lands outside his control. Finally, he included the stray arrow dialogue predicting his death.

Ibn Wāșil left no doubt about the significance of the stray arrow killing the besieger at Manbij:

The battle of 'Imād al-Dīn was similar to the battle of Balak. Who deems himself to be superior to God - may he be exalted - [God] proves him a liar. In a saying on the authority of God - may he be exalted - [it is stated:] 'I am God, the Lord of Mecca, I did not fulfil anything [any wish] for somebody who commits foul actions. ${ }^{, 45}$

(Ibn Wāṣil, Mufarrij, I, 99)

This statement and the preceding arrow dialogue, mainly served as a comment on the following death of 'Imād al-Dīn Zankī, which was now presented, via the 'arrow' motif, as providence. To die by an 'arrow' expressed the author's negative perception of the respective individual, generally a ruler. Such a death was not presented as chance, but as providence. The issues involved in the negative perception of the respective individual was partly linked to the issue of central versus local rule, but included also other elements as the following examples show.

A Turcoman amir, for example, was killed by a stray arrow during his presumptuous siege of Marāgha (near Tabrīz, present-day Iran), ending his career as a 'brigand' ${ }^{46}$ Here, the negative evaluation was simply based on the amir's record of theft and robbery. A scene involving Nūr al-Dīn furthermore invoked the standard issue of the ruler's piety. When he was in dire need of money to rebuild the army, some of his 
men advised him to stop the distribution of money and presents to religious scholars, the needy and others, at which the ruler replied:

How possibly can I withhold the pensions of those who fight on my behalf, while I am sleeping, with arrows which do not err and divert them to who does not fight on my behalf except when they see me, with arrows which might err or might hit? ${ }^{47}$

(Ibn Wāṣil, Mufarrij, I, 136)

It was his support of religious men, which would save him from an early death, while one-sided support of his military without any religious concerns would put him in danger him of being hit by a stray arrow.

The similarity between Balak who was killed by a stray arrow, and 'Imād al-Dīn Zankī who was killed by servants gone astray, was thus a decisive element in imbuing this scene with a specific meaning. The entire scene is characterized by an intensification of literary means such as direct speech with shifts between first and third person, oaths, poetry, letters, quotations from sacred texts and also explicit authorial intervention typical of crucial reports in Ibn Wāṣil. The killing of 'Imād al-Dīn Zankī himself by his servants was embellished by literary means such as direct speech and a final quotation of a verse by al-Mutanabbī. This dramatization, with different literary elements, hints at the great significance attached to such reports, compared to the standard flow of the narrative. The delegitimization of 'Imād al-Dīn Zankī at this point did not amount to a complete condemnation of the ruler. The following biography and also the preceding narrative included largely positive elements. Ibn Wāṣil's aim was to express his distrust of the central ruler attacking the different minor places in his realms - a rather obvious concern regarding the situation of Ayyubid Hama within the increasingly internally expanding Mamluk realms.

In Abū Shāma's text, important elements of Ibn Wāṣil's narrative were missing: the stress on the longevity of the local rulers besieged (300 years, in the case of Fanak at Ibn Wāṣil), the critical description of 'Imād al-Dīn Zankī's 'exceeding [zeal]' in unifying his lands, and most importantly Ibn Wāṣil's attempt to establish a firm link between 'Imād al-Dīn Zankī's death and the stray arrow motif. By mentioning 'Imād al-Dīn Zankī's death twice before the dialogue between (Ibn) Hassān and Sālim b. Mālik, Abū Shāma made the arrow dialogue loose the crucial function it played in Ibn Wāșil's text. The high number of repetitions and differences among the reports rendered a carefully built-up dramatization as per Ibn Wāṣil impossible.

Abū Shāma also criticized 'Imād al-Dīn Zankī, although in his narrative he included long reports on 'Imād al-Dīn Zankī's excellent qualities. Nevertheless, being beyond the limits of the Two Gardens disqualified him from the nearly unequivocal praise for rulers such as Nūr al-Dīn and Ṣalāḥ al-Dīn. Abū Shāma included a report spelling out some circumstances of the ruler's death missing from Ibn Wāṣil. On the night of his death, 'Imād al-Dīn Zankī was drunk, apparently after having spent the evening with 'several of his handsome servants whom he liked' ${ }^{48}$ Drinking wine was, in historical texts, as well as in other genres, strongly associated with notions of illicit 
behaviour in order to discredit individuals. This was even more so with Abū Shāma than with Ibn Wāșil, who also included poetry praising wine or alluded to the rather instrumental use of such accusations in the context of depositions. ${ }^{49}$ Thus, Abu Shāma's criticism was aimed at other issues than merely central versus regional rule. It was morally improper conduct (e.g. references to wine consumption and homoerotic allusions), which scandalized Abū Shāma. Being murdered in such circumstances was definitely not part of what Abū Shāma perceived as outstanding ideal rule.

The discussion of literary means besides arrangement has highlighted two aspects with regard to the modes of emplotment. First, the use of such means was precluded in the mode of Stasis, while the linear narrative characteristic for the mode of Process enabled their employment. Second, on the level of content, it was shown to what degree the issue of central versus local rule was a dominant threat in Ibn Wāṣil's text. The absence of the grand narrative underlying the mode of Stasis opened the field for the consideration of more mundane and immediate issues in a text prefigured in the mode of Process.

\section{Concluding the textual analysis: the pierced eye and the lost ring}

After outlining the role of the modes of emplotment with regard to the final sections, historicization, micro-arrangement and other literary means, the discussion will be concluded by analyzing the following account of the conquest of Bāniyās. ${ }^{50} \mathrm{Nu}$ r al-Dīn took the castle Bāniyās from the Crusaders in 560/1165 after two earlier failed attempts. Making his enemies believe that he was about to take Tabarīya, Nūr al-Dīn took advantage of the castle's weak defence to take it swiftly. ${ }^{51}$ The reports of this conquest are of special interest in highlighting the different literary strategies employed by Abū Shāma and Ibn Wāṣil.

This is because the report stands particularly at odds with modern expectations of historical narratives. It is significant, that the 'factual' information (the siege and conquest of Bāniyās), was of minor importance in the chronicles of the period. In Ibn Wāṣil, for example, it amounted to a third, and in Abū Shāma to a seventh of the total report. Instead, two stories, which became linked to this conquest, featured prominently in the narratives, one taking place during the siege and one after it. The first story referred to an arrow, which pierced the eye of Nūr al-Dīn's brother, Nuṣrat al-Dīn. ${ }^{52}$ Nūr al-Dīn commented on this: 'If you knew the reward prepared for you [in the hereafter], you would wish that the other [eye] had been hit, too. ${ }^{.53}$ The second purportedly happened on the return journey to Damascus when Nūr al-Dīn lost his ring in a thicket. After he had noticed the loss, he sent some of his companions back, indicating the place where he believed he had lost it. The ring was indeed found according to Nūr al-Dīn's instruction. A modern scholar commented on this scene that the two anecdotes on the lost eye and the lost ring 'belong rather to folklore than to history'. ${ }^{54}$ Thus, while most of the material previously discussed has been considered to be more or less unproblematic, this scene has been considered less trustworthy. However, the aim here is to show that such a 'folkloric' scene can be read as being quite similar to more 'historical' scenes. 
The report on Bāniyās appeared in a number of different versions in seventh-/ thirteenth-century chronicles. Ibn al-'Adīm and Sibṭ b. al-Jawzī had brief entries on the conquest, and also mentioned the arrow story. Ibn Wāșil largely followed Ibn al-Athīr's narratives ${ }^{55}$ by mentioning five lines of poetry and the ring episode, in addition to the arrow story. Abū Shāma's was the most extensive account, because he included additional lines of poetry as well as a historical parallel to the ring story from the period of Hārūn al-Rashīd. Ibn Wāṣil and Abū Shāma arranged their narratives on the Bāniyās conquest as shown in Table 4.

The connection of the anecdotes on the pierced eye and the lost ring to the $560 / 1165$ conquest of Bāniyās is indeed rather doubtful. Nuṣrat al-Dīn had lost his brother's confidence in the preceding decade by attempts to wrest power from him. He had twice aimed at taking effective power when Nūr al-Dīn had fallen ill. Nūr alDīn had excused the first attempt in 552/1157 as a misunderstanding. However, the second attempt in 553/1158 cost Nuṣrat al-Dīn his post as governor in Harrān and he was obliged to take refuge with the Saljuq sultan Qilij Arslān at Konya. While it cannot be conclusively disproved that Nușrat al-Dīn was indeed present during the siege of Bāniyās, it would be at least surprising if he were. ${ }^{56}$ Perhaps he appeared in connection with this conquest of Bāniyās as he had led Nūr al-Dīn's troops against this castle in an earlier attempt in 552/1157, while he was still in favour.

Furthermore, the story of Nuṣrat al-Dīn's eye also appeared in completely different contexts. Ibn Abī Ṭayy, for example, reported that after the loss of Harrān, Nuṣrat al-Dīn had moved to Constantinople. After the Byzantine Emperor had bestowed great honours on him, an indigenous notable referred to him out of jealousy as the one-eyed. This reference to the eye, which he had lost in an - unidentified battle some years prior to the Bāniyās report, led to a heroic duel, which Nuṣrat al-Dīn won. ${ }^{57}$

The second anecdote, concerning the loss of the ring, is even more difficult to attach to any concrete event. Abū Shāma himself argued in his passage no. 5 that the scene must have referred to another event. Ibn Munīr, the author of the poem on this event, had died in 548/1153, which made the attribution to the 560/1165 conquest

Table 4 Arrangement 'Conquest of Bāniyās'

\begin{tabular}{llrlr}
\hline No & Abū Shāma & Words & Ibn Wāṣil & Words \\
\hline 1 & Siege of Bāniyās/Nuṣrat al-Dīn & 96 & $\begin{array}{l}\text { Siege of Bāniyās/Nuṣrat } \\
\text { al-Dīn }\end{array}$ & 93 \\
2 & Poetry on Nușrat al-Dīn & 31 & & \\
3 & Conquest of Bāniyās & 35 & Conquest of Bāniyās & 24 \\
4 & Loss of ring, including poetry & 121 & Loss of ring, including poetry & 103 \\
5 & Question of origin of poem & 80 & & \\
6 & Further poetry on Nūr al-Dīn & 194 & & \\
7 & al-Rashìd's ring & 80 & & 220 \\
8 & Divine punishment for Mu'īn & 47 & & \\
& al-Dīn's father & 684 & & \\
& Total words: & &
\end{tabular}


impossible. Nevertheless, Abū Shāma continued to include poetry on the loss of the ring in this report and to historicize it with the story of al-Rashīd. Seemingly, the main point for him, as for the other authors, was not the story's factuality but the meaning attached to it.

Ibn Wāṣil and Abū Shāma largely agreed on the composition of the first anecdote. The 'arrow' motif, which hit the unjust individual in Ibn Wāṣil's narrative, was reinforced by Nūr al-Dīn's direct speech predicting his brother's fate in the hereafter. The comment could be read as a pious statement, promising the brother such recompense that he would wish for his immediate death, had he known it. ${ }^{58}$ However, given the turbulent relationship between the brothers, the placement of Nūr al-Dīn's comment in this context appeared rather as an ironic allusion. Abū Shāma reinforced the negative element by stressing the link between Nușrat al-Dīn and his father 'Imād al-Dīn Zankī in the poetry included in no. 2: 'The son of the one who causes to tremble in fear/what is between Aghmāt and China. ${ }^{59}$

In addition, Abū Shāma included other elements (which are exclusive to him) in order to elaborate on the subject. First, he depicted Nuṣrat al-Dīn in other reports in an emphatically negative light. The reports on the year 559/1164 are a case in point. In this year Nūr al-Dīn strove to support his officer Asad al-Dīn Shīrkūh who had to fight a Fatimid-Crusader coalition in Egypt. In order to split the Crusader forces, Nūr al-Dīn involved them in skirmishes in Syria. Nușrat al-Dīn appeared here in a rather unfavourable light fighting on the side of the Crusaders in Syria. Even his symbolic submission did not save him from Nūr al-Dīn's scorn:

His brother Nușrat al-Dīn was with the Crusaders. When he saw the banners of Nūr al-Dīn he could not refrain himself from driving the attack against his brother Nūr al-Dīn with all of his companions. When he came close to him [Nūr al-Dīn], he dismounted and kissed the ground. However, he [Nūr al-Dīn] did not take notice of him, so he [Nușrat al-Dīn] remained with his face on the ground. ${ }^{60}$

(Abū Shāma, Rawḍatayn, II, 91-2)

This negative depiction was linked with one of the important terms employed by Abū Shāma: the jāhilīya/ideal rule dichotomy. During his second illness in 554/1159 Nūr al-Dīn explicitly stated that he did not confer any authority on his brother Nuṣrat al-Dīn, as he had done during his first illness two years earlier:

I am concerned about the subjects and all Muslims of who follows me of ignorant [jāhilīn] rulers and oppressive tyrants. Regarding my brother Nușrat al-Dīn, I know of his character and evil deeds what makes it impossible for me to entrust him any affair of the affairs of the Muslims. ${ }^{61}$

(Abū Shāma, Rawḍatayn, I, 382)

This statement elevated the conflict between the two brothers to a more general level, in accordance with Abū Shāma's outlook. 
In addition, Abū Shāma reinforced the image of the just ruler Nūr al-Dīn speaking the verdict of the fate of unjust individuals in the hereafter. He included a dialogue at the end of the Bāniyās report between Nūr al-Dīn and the son of $\mathrm{Mu}^{\mathrm{c}} \overline{\mathrm{i}} \mathrm{n}$ al-Dīn Unur, who had been crucial in handing over the place to the Crusaders in 534/1140: '[Nūr al-Dīn] turned to him and told him: "The people rejoice once for this conquest, but you can rejoice twice." He asked: "How is that?" [Nūr al-Dīn] replied: "Because God - may he be exalted - cooled today your father's skin from hell-fire.",62 This dialogue reiterated the theme of the initial scene with Nuṣrat al-Dīn: Nūr al-Dīn speaking the final verdict. Abū Shāma thereby embedded the Bāniyās report firmly within two parallel scenes establishing Nūr al-Dīn's position.

Despite the different strategies employed by Ibn Wāṣil and Abū Shāma, the loss of Nuṣrat al-Dīn's eye took on quite similar meanings in both narratives. Arguably, the fact that the meaning of the motif 'arrow' was more firmly established for Ibn Wāṣil dispensed him from further emphasizing it. Abū Shāma, on the contrary, understood the necessity of including the parallel scene with $\mathrm{Mu}^{\prime} \mathrm{i} n$ al-Dīn Unur in the end to convey the scene's meaning.

However, with regard to the lost ring, the briefer version in Ibn Wāṣil's narrative excluded decisive layers of meaning conveyed by Abū Shāma who cited further poetry and historicized the scene. The story itself was the same in both texts:

Nūr al-Dīn returned to Damascus. He had at his hand a ring with a precious sapphire of best quality. It fell from his hand in the thicket of Bāniyās, which was of many trees with entwined branches. When he departed from the place where he had lost the stone he became aware of it. He sent some of his companions to search for it and indicated them its place, saying: 'I believe there it got lost.' They returned and found it. ${ }^{63}$

(Abū Shāma, Rawḍatayn, I, 437-8)

The following panegyric poetry by Ibn Munīr for Nūr al-Dīn, included by both Abū Shāma and Ibn Wāṣil, alluded to the symbolic potential of the ring: 'Nobody but Sulaymān [King Solomon] gave it.' This line referred to the Prophet Sulaymān's signet ring, which was renowned for its role in many of his miraculous deeds. ${ }^{64}$ The lost ring of Nūr al-Dīn was symbolic of his ability to rule, since signet rings, authenticating the ruler's written word, were symbols of power and part of his regalia.

The loss and subsequent retrieval of the ring by Nūr al-Dīn was, in essence, a reflection on the theme of the endangered position of any ruler. The introduction with Nuṣrat al-Dīn prepared the background of alluding to potential revolts within his own realm. The 'arrow' had settled the problem with regard to the immediate danger of Nuṣrat al-Dīn. However, it was only with the ring that Nūr al-Dīn was more generally depicted to be beyond these dangers. He lost the ring in the thicket, 'which was of many trees with entwined branches' - a reference to the tangled and dangerous environment in which he had to act constantly.

It was at this point that Ibn Wāṣil concluded his narrative on Bāniyās and turned his attention to an unrelated obituary notice. Abū Shāma, however, continued by 
proving first of all that the ring story was unconnected to the Bāniyās report. Citing Ibn Munīr's Dīwān he linked it to an unidentified hunt. This did not deter him from setting the story in a textual context more fitting to his narrative by including further poetry and historicizing it.

The following poem - exclusive to Abū Shāma - established an explicit link between the anecdote and the early Islamic period. Nūr al-Dīn's military exploits were here compared to the post-Muhammadian conquests (futüh) and the battle at Badr in the year 2/624, which in Islamic tradition was one of the decisive early victories of the Prophet's men. This link reminded contemporary readership of the well-known story of the lost ring of the third 'Rightly Guided' Caliph 'Uthmān. ${ }^{65}$ 'Uthmān's ring, the Khātim al-Nab̄i, had been handed down to him from the Prophet Muhammad via the Caliphs 'Umar and Abū Bakr. When sitting on the edge of the well at Arīs near Medina, 'Uthmān fiddled with the ring until it fell into the water. Despite numerous attempts to retrieve it, and a magnificent reward offered by 'Uthmān for its finder, the ring remained lost. ${ }^{66}$ In traditional literature this event was employed in order to symbolize the turning point between the Caliph's 6 years of good rule and the following 6 years of lawlessness, disorder and rebellious movements. ${ }^{67}$

Furthermore, the poem reiterated Abū Shāma's intention by also referring to the work's title: 'With Nūr al-Dīn [the noble rule] dressed in flowers of gardens / the fruits of which are the most precious virtues'. ${ }^{68}$ The two decisive elements in Abū Shāma's title as reworked in the narrative, were thus here reiterated: the concept of enclosed gardens of ideal rule being linked to the early Islamic period.

Following the poem, Abū Shāma included a story 'which is similar to this felicity', ${ }^{69}$ and brought one of his favourite ideal rulers of the post-Golden Age period into the picture, Hārūn al-Rashīd. The 'Abbasid caliph al-Hādī (d. 170/786) demanded the valuable ring from his brother al-Rashīd, which the latter had taken from their father. Confronted with his brother's insistence, al-Rashīd preferred to throw the ring from a bridge in Baghdad into the Tigris. After he had taken power, al-Rashīd returned to this same bridge, threw a valueless lead ring into the river and ordered divers to retrieve it. Miraculously, they returned with the first valuable ring, 'which was considered [a sign of] al-Rashīd's felicity and the endurance of his reign'. ${ }^{70}$

The conflict between the two brothers al-Hādī and al-Rashīd over the ring reflected their struggle over the succession of the caliphate. Al-Hādi tried during his short rule to remove al-Rashīd from his position as heir apparent. The conflict culminated with al-Rashīd being put into prison, and escaping certain execution only by the sudden death of al-Hādī. After the suspicious death of his brother, al-Rashīd was able to secure power. ${ }^{71}$ The parallels between al-Rashīd and Nūr al-Dīn were manifold. Both had to contend with their brothers either to secure or to attain their position as rulers. Both went through difficult periods during the conflict and emerged only after a prolonged dispute in their ruling positions. These conflicts were symbolized in both cases with the loss and miraculous retrieval of their rings. The irretrievable ring of 'Uthmān, on the contrary, symbolized the 
contrary course of events as it alluded to the subsequent tragic events including his murder and the linked split within the community.

With the elements exclusive to his narrative, Abū Shāma considerably widened the meaning of the Bāniyās report. Up to the point where Ibn Wāṣil broke his narrative off it symbolized the precarious situation of any ruler, but with the following poetry and historicization, Abū Shāma set the issue in a wider context of ideal rule by referring explicitly to the early Islamic period and the reign of al-Rashīd. The ring was no longer just the symbol for any rule, but for the ideal rule as it existed in the world of the Two Gardens. The full implication of Abū Shāma's short allusion to Nuṣrat al-Dīn as a tyrannical and oppressive ruler became here apparent. In Ibn Wāșil's narrative, Nușrat al-Dīn appeared as the example of an unspecific contender for power. Abū Shāma, on the contrary, set him into his dichotomous notion of ideal versus $j$ jahili rule. Once again, the mode of Stasis considerably changed the scope of the narrative. While it seemed to widen the narrative by including further references, the mode of Stasis limited it in fact strongly by attaching the symbol of the story to one particular kind of reign only. In Ibn Wāșil's text, the mode of Process allowed the story to be integrated into its continuous narrative without claiming any specificity.

The above textual analysis has shown that Ibn Wāṣil and Abū Shāma constructed distinctively different narratives. The underlying question in the course of the discussion has been how these two authors entered into a dialogue with the past in order to construct a meaningful narrative for their presentist concerns. It emerged that the modes of emplotment played a crucial role in rendering the past readable for their contemporary audiences. By prefiguring their story in a specific mode, the material gained significance well beyond the factual surface.

The presentist aspect of historical writing as analyzed here was not specific to the Islamic lands, but has been amply discussed with respect to other regions such as medieval Europe. Studies have demonstrated how historical writings performed a variety of crucial roles here, for example, the transformation of the Norman conquerors of Sicily in the eleventh century from aggressive outsiders to legitimate authority, ${ }^{72}$ and the attempts to create a romanticized past for the weakened aristocracy in thirteenth-century Flanders. ${ }^{73}$ The chroniclers in these contexts had recourse to the past in order to advance specific readings of the present. ${ }^{74}$ In general, 'the [European] medieval sense of history was a sense of the past orientated towards the present ${ }^{75}$ - and in this respect not strongly different from Arabic historical writing. Historical writing was one of the preferred genres for elaborating presentist concerns as it was endowed with a sense of being realistic and free of imagination. ${ }^{76}$

The preceding analysis not only asked how Abū Shāma and Ibn Wāṣil conducted the negotiation between past and present, but also what they intended to express. On a deeper level the outwardly quite similar texts expressed two radically different versions of what the past should mean to their present. The dichotomous vision of Abū Shāma expressed in terms of present jāhili versus past ideal rule, stood uneasily with Ibn Wāṣil's concept of a continuous ideal rule in both past and present. It is this 
issue (the 'what question') which the next section sets out to consider in more depth. As the recurring issue was the question of ideal rule, the outlook of the two narratives in this regard will be set in relation to the genre of political thought.

\section{Chronicles and political thought}

Secondary literature on concepts of ideal rule in medieval Islamic societies has dealt mainly with those writings explicitly devoted to political ideas. ${ }^{77}$ Such writings fell into the three main categories of texts written by jurists, those written by philosophers, and those belonging to the genre of mirror for princes and administrative handbooks. The following argumentation assumes that the two chronicles under consideration can be read as a further source on this issue. ${ }^{78}$ Certainly, chronicles lacked the explicit legalistic and philosophical statements of the main genres of political thought. However, it was in chronicles that such explicitly formulated ideas were taken up, reworked and possibly also, to a certain degree, prepared. El-Hibri (1999) has shown how, for the formative period, 'álims spelled out their views on leadership not via mirrors for princes but in historical narratives. ${ }^{79}$ Chronicles are an example of how explicitly normative ideas were employed in genres focusing outwardly on other issues.

The tendency of Abū Shāma and Ibn Wāṣil to also conceive their works as repositories of advice for rulers is seen in their texts. Abū Shāma stated in the introduction to his Rawdatayn that he composed this work so that a ruler 'who follows in his reign this conduct [i.e. of Nūr al-Dīn and Șalāh al-Dīn] might read it'. His hope was that their story might be 'an example for the later maliks and sultans' ${ }^{80}$ Even more explicitly he stated in his summary of the work: 'My principal intention with this work was to stir up the rulers to emulate them [i.e. Nūr al-Dīn and Ṣalāḥ al-Dīn] and think it despicable to fall short of them. ${ }^{81}$

These statements were not mere formulas employed as a standard procedure, but were specific to the Rawdatayn. In his simultaneously written Dhayl the focus on this potential readership disappeared completely. He described this work as an admonition to lead a pious life directed at an unspecified general public:

To read books of history contains a lesson, and to recite them restrains from dangers. This is especially so if those who die each year among the acquaintances, brothers, relatives, neighbours, wealthy and the sultan are mentioned. All this induces those with insight to asceticism in this world. It also awakens a desire to act for the supreme life, to prepare for what they will encounter and for abstaining from the little that they will leave behind. ${ }^{82}$

(Abū Shāma, Dhayl, 5)

Compared to Abū Shāma's Rawdatayn and its summary, Ibn Wāṣil did not include such explicit statements in his introduction. However, in the course of his text he occasionally inserted phrases into the narrative hinting at similar intentions. 
He concluded for example descriptions of what he perceived to be outstanding deeds of Nūr al-Dīn and Șalāh al-Dīn respectively with "like this, rulers should be!'83 and 'like this, the sultan should be!' ${ }^{4}$ In a similar vein al-Malik al-Ashraf Mūsā (d. 635/1237) was praised with the words: 'We have not heard of a ruler or a powerful man since the Barmakids who performed such deeds of generosity and magnanimity. ${ }^{85}$ Furthermore, the work's dedication to the ruler of Hama shows that it was directed primarily to an audience situated at the court.

Persian and Arabic political writings prior to, and contemporary with, Ibn Wāṣil and Abū Shāma generally centred on the issue of the rulers' legitimacy, as seen in the writings of authors such as Ibn al-Muqaffa' (d. 142/759), al-Māwardī (d. 450/1058) and Ibn Jamā'a (d. 733/1333). Of particular importance for all authors was the question of which role the caliph played vis-à-vis other rulers in the Islamic lands. This issue was particularly at stake with the decreasing importance of the caliphs compared to rulers such as the Saljuq sultans. Whether power below the level of the caliphate was distributed according to the Saljuq tradition (partition among the male family members) or in another way was discussed in more depth only after the fall of the caliphate in the seventh/thirteenth century.

The authors' concepts paralleled the grand lines of the caliphate's development as a ruling institution. Writers such as Ibn al-Muqaffa' focused on the principles of the caliphate as head of a unified administration of the Islamic lands. In a period when the caliph still yielded considerable political power, the main issue was how this supremacy could be efficiently maintained. ${ }^{86}$ By the time of al-Māwardī, the caliph's political power had been largely reduced, and new issues were at stake in the genre of political thought. Al-Māwardī included this weakened influence in his theory of the caliphate by acknowledging that the delegation of power from the caliph to local rulers was legitimate. With the development of the concept of the amirate of usurpation (imārat al-istila'a), even the previously irregular situation of local rulers taking power without delegation from the caliph became formalized, and hence acceptable. In his tradition authors continued to integrate the permanent rise of de facto independent local rulers into their theoretical frameworks. Al-Ghazālī developed a new basis for the relationship between the caliph (the executor of the shari ${ }^{-} a$ ), and the sultan (the coercive power). Together with the 'alims as the interpreters of the divine law, they formed the essential parts of any leadership (imamate). ${ }^{87}$

Authors such as Ibn Jamā'a and Ibn Taymīya, writing in Syria and Egypt in the early eighth/fourteenth century, finally explicitly accepted the disappearance of any caliphal authority. The Shāfi ite scholar Ibn Jamā'a (d. 733/1333) started his career in Syria when he was appointed as khațīb of the Aqșā Mosque in Jerusalem in 687/1288; he moved to Egypt upon his appointment as chief judge in 690/1291. In the following decades he held this post alternatively in Damascus and Cairo. Members of his family gained a certain prominence after his death by holding posts in Syria and Egypt. In his youth he read Abū Shāma's Dhayl with its author. ${ }^{88}$ The more renowned Hanbalite scholar Ibn Taymīya also spent most of his life either in Damascus or Cairo. He centred his learned activities mostly on the field of jurisprudence, and his only positions were teaching posts he held in madrasas. He has already been described 
(in Chapter 4) as a mujtabid striving to suppress innovations. His stances repeatedly brought him into open conflict with the Mamluk authorities. During one of his spells in jail Ibn Jamāaa, whose relationship with the Mamluks was rather harmonious, interrogated him.

Both authors' political treatises reflected the disappearance of the Baghdad caliphate as the unifying symbol of the Islamic community during the Mongol invasions. Although the Mamluks retained a 'puppet' caliph at their court, neither of these two contemporary writers took his role seriously, and both developed a vision for a system without a caliph. However, the concerns and the outlook expressed in their treatises for this state of affairs were radically divergent.

Ibn Jamā'a aimed to legitimate the status of rulers after the de facto disappearance of the caliph, who among Sunnis had been seen, theoretically at least, to confer authority on the respective local ruler. ${ }^{89}$ The caliph played hardly any role in his Tabrīir al-abkām fì tadbìr abl al-islàm (Rules for the Governance of the People of Islam): The sultan took the caliph's position, or, more precisely the sultanate absorbed the caliphate. The sultanate was now directly subordinated to God without the intermediary position of the caliph. Most importantly, Ibn Jamā'a argued that the seizure of power itself was sufficient to detain legitimate authority:

When there is no imam and an unqualified person seeks the leadership and compels the people by force and by his armies, without any bay ${ }^{\prime}\left[{ }^{90}\right]$ or succession, then his bay'a is validly contracted, and obedience to him is obligatory, so as to maintain the unity of the Muslims and preserve agreement among them. This is still true, even if he is barbarous or vicious, according to the best opinion. When the leadership is thus contracted by force and violence to one [person], and then another arises who overcomes the first by his power and his armies, then the first is deposed and the second becomes imam, for the welfare of the Muslims and the preservation of their unity, as we have stated.

(Ibn Jamā'a, Tahrīr, 357; translation Lewis (1988), 102)

Here, the term 'imam' still referred to a caliphal-like position of centralized authority. However, Ibn Jamāa also legitimated the violent seizure of power by local rulers, whom the respective imam had to acknowledge. The rule of any person seizing power in a specific region was thus thereby considered to be, de facto, lawful. ${ }^{91}$ His treatise's main concern was to narrow the gap between theory and practice, which amounted to endorsing the status quo of his day without considerable limitations.

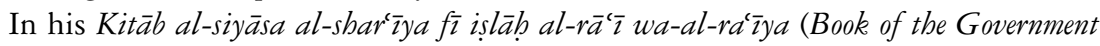
in Line With the Divine Law: The Rectification of the Shepherd and the Flock) Ibn Taymiya went even further in his stance towards the caliphate. He argued that it was in any case not legally required by divine law, which demanded only obedience to those holding power without specifying a certain institution, such as the caliphate. ${ }^{92}$ Unlike Ibn Jamā'a, however, his main concern was not to legitimate the status quo, but to promote a reform of the community and the state by 'reinstalling' the crucial 
role of the $\operatorname{sharī'}^{-} a$. This reform took the period of the four Rightly Guided caliphs as a point of reference - an epoch, which had also been, according to Ibn Taymìya, the sole period of a true caliphate. The right path for his period was not to elaborate further theories of the caliphate or sultanate, but to focus on the essential element in ideal rule: the comprehensive application of the $\operatorname{shar}^{-} a$. The unity of the community did not depend on the number of rulers, but on how the $s h a r \bar{l}^{\prime} a$ was applied in every region. He particularly stressed the participation of the 'álims, who had to be consulted for daily governance by the respective sultan, malik or amir. The ideal was therefore a unity of ruler and those qualified to administer the divine law: al-siyasa al-shar'iya. Being fiercely opposed to Ibn Jamā'a, and addressing his work to those ruling, Ibn Taymiya hoped to influence the conduct of government in his period.

Ibn Wāșil and Ibn Jamā'a shared the acceptance of the status quo: rule was legitimate as it existed in their present. The seizure of power based on military force alone without delegation from a central institution was acceptable; neither was this absence of delegated authority an impediment to good rule. With both authors writing in the period after the extinction of the Baghdad caliphate, regionalized rule, whether on the level of grander entities such as the realms ruled by the Ayyubids or Mamluks, or on a smaller scale such as autonomously ruled towns, was not even a theoretical problem for them.

In Ibn Wāṣil's case this might have been linked to the social context in which he acted: his close integration to networks of prominent figures at different courts arguably precluded the presentation of one single mode of rule as the only validly legitimated one. In his perspective the ruler was not the decisive figure in preserving good rule. Rather, this task pertained to the elites who had been present at the different courts. Hence, the rise of one of these amirs to power in the form of a localized dynasty posed no problem; on the contrary, the ruling elites below the level of rulers were, for him, exactly the 'breeding' ground for the continuation of good rule.

Ibn Taymīya and Abū Shāma did not strive to legitimate the status quo. Rather, their aim was to change or reform it as they shared a distrust and rejection of the present state of affairs. Neither writer considered rule qua rule to be sufficiently legitimate but imposed sharī a-orientated criteria. ${ }^{93}$ Abu Shāma wrote the Rawdatayn in a period when the caliphate still existed. It continued to play a considerable role in his text, for example, in the form of legitimating letters as the one discussed in the Mosul scene. However, he took account of the institution's weakening and focused in his text on the level of sultans to display his vision of ideal rule. The caliphate played merely a symbolic role in his text, which could serve as point of reference for his general stance. Interestingly, more than two centuries later, when the caliphate was even more marginal in terms of effective power, it played a similar role in the historical narrative of al-Suyūți. ${ }^{94}$ By refusing the idea that a ruler could be legitimated without caliphal consent (and also by glorifying Șalāh al-Dīn) al-Suyūṭ̂̄ offered a glimpse of 'pious opposition'95 to the present state of affairs.

Such an 'opposition' towards the ruling elites should certainly not be overestimated in the writings of Sunni authors. Aversive to civil strive (fitna), Sunni authors generally preferred unjust rule to rebellions again unjust rulers. However, individuals 
such as Ibn Taymīya openly expressed their dissatisfaction with the present state of affairs. Although Abū Shāma was more quietist, his writings show that this quietism did not exclude the formulation of criticisms and the (discursive) taking of an opposed stance. This was because, for Abū Shāma, the 'breeding' ground for good rule was specifically not the ruling elites, but the group of religious scholars sharing his outlook. In periods of unjust rule, such as his present, it was the duty of sincere religious scholars to abstain from involvement in the matters of rule as far as possible.

In order to pursue the issue of legitimacy further, the discussion will now return to Ibn Wāṣil's and Abū Shāma's texts themselves by taking up a further scene included in both chronicles. The focus will be on the degree of legitimacy the authors ascribed to rulers besides Nūr al-Dīn and Șalāh al-Dīn. As the outstanding status of the two latter rulers was beyond any doubt, it was in the evaluation of other rulers that the authors' positions emerged most clearly. The question at stake was how the holding and losing of power was legitimized: was the exercise of power or the deposition of an individual by a stronger contender sufficient by itself to be endorsed? Or, were such events to be evaluated in the framework of criteria derived from a vision of ideal rule informed by elements of the shari ' $a$ ?

Ibn Wāṣil and Abū Shāma agreed on the broad factual outline of the report discussed in the following: in the year 568/1173 Nūr al-Dīn took the occasion of a Dānishmendid-Saljuq conflict in Bilād al-Rūm to intervene on the side of Dānishmendids. After some successful conquests by Nūr al-Dīn, the Saljuq ruler Qilij Arslān sought a truce. Nūr al-Dīn accepted without hesitation, in order to be able to return to his mainland Syria. ${ }^{96}$

Ibn Wāṣil started the report with an unequivocal statement of what he considered to be Nūr al-Dīn's intention: 'Then Nūr al-Dīn moved to the realms of 'Izz al-Dīn [...] al-Saljūqī (the lord of Konya) with the resolution to fight him and take his lands. ${ }^{97}$ This was followed by a short description of the conquests and the truce. The report ended with Ibn Wāșil's typical tendency to take an interest in affairs beyond the realms of his Zangid and Ayyubid protagonists - the subsequent succession of Saljuq rulers up to the author's present and the state of affairs under Mongol domination was discussed.

For Ibn Wāṣil this conflict was between two overlords of different regions involved in a territorial conflict - similar to his description of the Mosul scene (see earlier). The basic assumption was identical in both scenes: the rulers in conflict did not act on different levels of legitimacy. Certainly, they were involved in territorial disputes, but these did not undermine their basic status as rulers. There were no textual elements aiming at delegitimizing the Saljuq dynasty. Rather, the inclusion of the Saljuq rulers' succession over the following decades until the author's present made clear that they deserved an independent role in the narrative beyond being adversaries of Nūr al-Dīn. Nūr al-Dīn's move appeared here as a normal attempt to enlarge one's realms to the detriment of the neighbouring dynasty. Ibn Wāṣil changed his outlook towards such encounters only when it came to conflicts involving overlords and regional rulers, such as the siege of castle Jabar, where he saw the expansion with distrust.

Abū Shāma, though, stressed loftier aims in describing Nūr al-Dīn's campaign: 'Nūr al-Dīn moved to the north to settle there the disorder. ${ }^{\text {'9 }}$ In the subsequent 
poem for the ruler these aims were enlarged upon by calling him by his reigning title 'The Righteous King [al-Malik al-'Ādil]', whose 'generosity is unmatched among mankind'. ${ }^{99}$ Most importantly, Abū Shāma included a letter by Nūr al-Dīn setting out the conditions for a truce, which turned the conflict most clearly into an affair transgressing mere expansionary intentions. In the letter, Nūr al-Dīn demanded that Qilij Arslan should restate his Muslim faith in order to disprove accusations of adherence to 'the philosophical schools of thought' (madhāhib al-falāsifa).

Furthermore, the letter accused him not only of neglecting the jibād against the Byzantines, but obliged him to support Nūr al-Dīn in the jih ād against the Crusaders and to take it up himself. To include the accusation of neglecting jiba $\bar{a}$ carried a considerable weight, as it was during Nūr al-Dīn's reign that the idea of jibād gained a prominent position within the Syrian context. The aborted Crusader siege of Damascus in the mid-sixth/twelfth century, as well as the concurrent increase in Crusader involvement in Egyptian affairs, drove Nūr al-Dīn to adopt a more bellicose attitude towards them. ${ }^{100}$ This increased importance of jiba $\bar{d}$ activities for rulers' self-presentation during the counter-Crusade periods meant that the accusation added to the image of an unfit ruler, who even had to restate that he was a Muslim at all.

In Abū Shāma the core conflict in this scene did not revolve around the issue of territorial expansion, but focused on the question of legitimacy. As an ideal ruler Nūr al-Dīn had the moral right and duty to subdue rulers who did not fulfil the basic requirements of the shari ' $a$, such as adhering to the faith or fighting the non-Muslim enemy. These elements here played the same role as they did in the Mosul scene where they set Șalāh al-Dīn into a larger framework of divine providence and ideal rule. Due to the relative marginality of the events, the emphasis was here not so strong, but the underlying message remained. By delegitimizing the enemy, Nūr al-Dīn was endowed with moral superiority.

Thus, the ideas expressed by Abū Shāma and Ibn Wāṣil can be read as aspects of political thought being reworked in the genre of history. Certainly, these ideas lacked systematic formulation. However, Ibn Taymìya's criterion of $\operatorname{shari~}^{-} a$-orientation for legitimate rule and Ibn Jamā'a's stance to legitimate rule qua rule displayed strong affinities to these historical narratives produced in the preceding generation of writers. ${ }^{101}$

The outlooks expressed by Abū Shāma and Ibn Wāṣil on the issue of ideal rule were intimately linked to their respective modes of emplotment. The 'rule qua rule' position could be textually reproduced in a narrative prefigured by the mode of Process. The continuous stream of acceptable rulers was emplotted into factual linearity, where the Ayyubids were merely one example among many. The 'sharì' $a$ ' orientation, on the contrary, was underlain by the mode of Stasis. The application of external criteria for evaluating the legitimacy of rule, led evidently to a less continuous development in describing the past. By singling out specific periods, a clear profile emerged where ideal rule had been situated. 


\section{RECEPTION AFTER THE SEVENTH/THIRTEENTH CENTURY}

Chapters 5 and 6 proposed readings of the Rawdatayn and the Mufarrij as specifically intended by the authors. This final chapter will abandon the medieval context in order to discuss the texts' reception in the following centuries. The aim of this discussion is twofold: on the one hand it will be shown that these authors' intentions especially in Abū Shāma's case - were indeed understood as such in the following centuries. On the other hand, the reader's room for manoeuvre will also be referred to as Abū Shāma's text was also subject to interpretations, which went well beyond his intentions. This inquiry will centre on the reception of the works as complete entities; that is to say, it will not examine the quotation of fragments by later authors. ${ }^{1}$

\section{The Mufarrij}

Four manuscripts of Ibn Wāṣil's text are known to exist at present. The Istanbul ${ }^{2}$ and Paris $1703^{3}$ manuscripts were written during the lifetime of the author; the Cambridge manuscript was arguably copied in the following century ${ }^{4}$ while Paris 1702 was copied in the early ninth/fifteenth century. ${ }^{5}$ Notes on the manuscripts show that they were also in circulation in the following centuries. For example, the last note on the Istanbul manuscript refers to the year 877/1472, and the last note on the Paris 1703 manuscript refers to $1019 / 1610-11 .^{6}$

However, it seems that by this point the work was almost forgotten, since the Egyptian copyist of the early ninth-/fifteenth-century manuscript (Paris 1702) could already claim to be its author. For, other than changing the first and last folios, the copyist did not even bother to eliminate passages that ascribed the work to Ibn Wāșil. ${ }^{7}$ The fact that a rather obscure figure could try to advance his claim in such a clumsy way seems to illustrate the work's marginality some 150 years after its production. This impression is supported by a little piece of paper, which was pasted over Ibn Wāșil's name on the title page of the Cambridge manuscript. Here again, someone had attempted to hide Ibn Wāṣil's authorship without displaying particular sophistication.

The Mufarrij did not spread widely among the religious scholars either of its time or the following centuries. The manuscripts carry comparatively few notes. Three of 
the notes on the extant first and last folios refer to the possession of the manuscript (tamalluk). Only two refer to a reading of it, ${ }^{8}$ while not a single one documents a reading in the presence of a scholar. ${ }^{9}$ Only a single prominent scholar was known to have received an ijāza for works by Ibn Wāṣil. This ijāza refers furthermore to all works by him without singling out the Mufarrij. ${ }^{10}$

However, the Mufarrij gained a certain prominence in court circles, witnessed by the fact that its supplement was written by the court secretary 'Alī b. 'Abd al-Rahīm, to whom Ibn Wāṣil's had dictated the Mufarrij. ${ }^{11}$ The copyist who later pretended to be the author of the Mufarrij was a certain Shams al-Dīn Ahmad b. Ahmad b. Muhammad al-Zaynī. He described himself as the Secretary of State (kātib al-sirr) of the Mamluk sultan Barqūq (r. 784/1382-791/1389 and 792/1390-801/1399), although his identity cannot be established as the relevant sources do not mention a Secretary of State by this name. ${ }^{12}$ Furthermore, in the manuscript's colophon, this Shams al-Dīn wished the sultan that his rule might last twenty years after Barqūq had died. Nevertheless, although the copyist probably did not hold the post he pretended to, it seems that he was at least in proximity to the Mamluk court, or strove to be in proximity to it.

The circulation of Ibn Wāsilil's Mufarrij in court circles was paralleled by the course of his Șalihian History. The London manuscript does not contain any notes, which might hint at scholarly use; furthermore, the script was extremely clear, and it was arguably written for ceremonial ends rather than being a copy for daily scholarly use. Large spaces, showing that the scribe was not worried about the cost of paper, separate the lines; this lavish use of paper aimed at a formal celebration of the ruler going hand in hand with the textual celebration.

The Mufarrij was, in its later transmission, limited to the Egyptian/Syrian regions. Its supplement was written in Hama, the copyist claiming authorship lived in Cairo, in 742/1341 a certain 'Alī b. al-Hasan b. 'Alī b. 'Abd al-Wahhāb al-Hamawī bought a manuscript of it in Cairo ${ }^{13}$ and in 1019/1610-11 a Muhammad b. Ahmad b. Ismā̄îl al-Dimashqī al-Maqdis̄i bought another manuscript of it. ${ }^{14}$ Thus, the Mufarrij enjoyed only a brief popularity and was geographically limited in its readership. The few instances of transmission took place in the proximity of courts, which was a fitting context for a work produced in a similar context and which advanced the vision that ideal rule, irrespective of specific individuals and dynasties, was a continuous reality.

\section{The Rawdatayn}

The Rawdatayn was, in contrast to the Mufarrij, transmitted on a much larger scale as is clear from the nearly twenty surviving manuscripts. ${ }^{15}$ The dates of copying of the manuscripts show a reasonably even distribution over the centuries, with a concentration in the period following the death of Abū Shāma: Eight manuscripts alone were copied in the seventh/thirteenth and eighth/fourteenth centuries. ${ }^{16}$ From the ninth/fifteenth century only 1 copy has been preserved, followed by 3 each in the tenth/sixteenth and eleventh/seventeenth centuries. The copying then faded away 
with 2 manuscripts dated to the twelfth/eighteenth century and 1 to the thirteenth/nineteenth century. In the mid-thirteenth/nineteenth century, however, with the rise of printing in the Arabic Middle East, the Rawdatayn was published in this new form as discussed in the following section.

The notes on the manuscripts furthermore show that the Rawdatayn was often read and that its manuscripts regularly changed owner. For example, a manuscript copied in the eighth/fourteenth century bears a total of 9 notes, among them 1 of reading and 4 of possession, ${ }^{17}$ and a manuscript copied in the ninth/fifteenth century bears 1 reading note and 6 notes of possession. ${ }^{18}$ The notes show also that the use of the Rawdatayn did not stop in later centuries: a manuscript from the tenth/sixteenth century, for example, bears notes referring to 939/1533,1009/1600, 1040/1630-1 and 1092/1681. ${ }^{19}$

During his lifetime Abū Shāma introduced the Rawdatayn into the scholarly world through his regular teaching sessions. The teaching of his works was praised in 648/1251 in his study circle in the Umayyad Mosque in Damascus with a poem in which the Rawdatayn was already mentioned. ${ }^{20}$ In this mosque in the following year he taught the work again in its entirety; ${ }^{21}$ in $655 / 1257$ he issued 2 ijäzas for the work after its reading; and finally 1 year before his death he issued ijāzas to 9 individuals for the whole work after its reading in the Dār al-Hadīth al-Ashrafīya. His own statements show that he intended this wide dissemination of the work. While asserting that he simplified the prose of his predecessors, he underlined his underlying intention: 'I wanted the elite and the commoners to understand the words. ${ }^{22}$

The students who received ijāzas to a large degree reflect Abū Shāma's modest status in the Damascene world of learning. This was shown in Chapter 3, with special reference to his teaching of the Rawdatayn. While the Rawdatayn was taught regularly, and came into circulation in this initial phase among minor scholars, it was not firmly established among the more prominent scholars. Yūsuf b. Muhammad al-Shāfi ${ }^{\top} \bar{i}$ was the exception, and his transmission was, significantly, one of the two chains, according to which the Rawdatayn was copied. ${ }^{23}$

With the second major chain of transmission, the Rawdatayn entered in the following century the context of more prominent scholars. In 733/1333 and $734 / 1333$ a professional scribe made two copies of the Rawdatayn, which he based on a copy by Najm al-Dīn Ahmad b. Muhammad b. Șașrā (d. 723/1323). ${ }^{24}$ Najm al-Dīn did not quote any chain of transmission going back to Abū Shāma, but stated simply that he made his copy from an autograph manuscript. However, the appearance of Najm al-Dīn in the transmission of the Rawdatayn is interesting since he was a descendant of one of the prominent Damascene families. During the seventh/ thirteenth century his family had produced, among others, three controllers of the

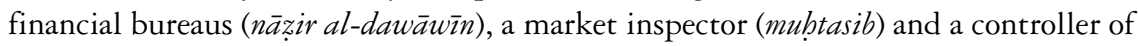
the treasury. ${ }^{25}$ Najm al-Dīn himself held teaching appointments at several schools, and was also chief judge in Damascus for the last two decades of his life. In this post he figured prominently in the religious and civil events which took place in the town during this period, including the conflicts surrounding Ibn Taymīya.

It therefore took several decades for prominent scholars of the town to start becoming interested in the Rawdatayn, and the three surviving manuscripts of the 
abridgement of the Rawdatayn ('Uyūn al-rawdatayn) seem to confirm this. While one manuscript was an autograph, the second was only copied during the eighth/ fourteenth century by Khalīl b. Kaykaldī al-'Alā'̄ (d. 761/1359), an eminent badìth scholar who held a number of posts in both Jerusalem and Damascus. ${ }^{26}$

In the eighth/fourteenth century the Rawdatayn moved into a new realm - the courtly world. While Abū Shāma stated in his introduction to the work that he had written it to set an example for rulers, individuals at courts or rulers themselves were hardly exposed to it. Considering Abū Shāma's position in Damascus it is not surprising that his text required some decades before it was read in both wider scholarly circles and courtly circles. The somewhat oppositional message of the text hardly made it attractive for those wielding power. Over time it seems that this message itself became a discourse from the past about the past, which was not necessarily perceived to be of direct relevance to the respective present. It described an exemplary period of history, which could be discussed without endangering the present state of affairs.

During the reign of the Mamluk ruler al-Malik al-Nāṣir Muhammad b. Qalāwūn (r. with interruptions 693/1293-741/1341) a copy of the Rawdatayn was written with a slightly different title. ${ }^{27}$ The name of the ruler was produced in golden letters on the title page, as it was apparently intended for submission to him. The courtly reception of the work also continued in the succeeding centuries. A certain 'U[?]lwān b. 'Abd al-Nabī al-Hanafī, scribe of imperial decrees at the Ottoman sultan's port and tedhkirici ${ }^{28}$ in the dìwān Mișr, copied the Rawdatayn in 1005/1596. ${ }^{29}$ And as late as in 1278/1861 a scribe named 'Alī al-Suyūți copied it at the instance of an amir named 'Abd al-Hamīd Bey Nāfi'. ${ }^{30}$

\section{The Rawdatayn in nineteenth-century printing and press}

The 1278/1861 manuscript was the last of the Rawdatayn to be produced. With the advent of the printing press in the Islamic lands the main medium of disseminating the written world gradually shifted to printed books, journals and newspapers. One of the earliest Arabic newspapers was The Garden of News (Hadīqat al-akbbār) founded in 1274/1858. ${ }^{31}$ It was based in Beirut, the centre of printing and press activities in the Arabic Middle East until Cairo became dominant in the late 1280s-early 1290s/1870s. The founder of The Garden of News was the GreekOrthodox writer and businessman Khalīl al-Khūrī (d. 1325/1907) who had founded The Syrian Press (al-matba'a al-Sürīya) in the previous year. His newspaper was read by a wide audience across the Islamic lands, as were other print mediums at that period, and reached out to both Christians and Muslims simultaneously. Like many other societies, periodicals and presses founded by the educated elite during this period the newspaper had a strong accent on 'modernization'. ${ }^{32}$ As well as overviews of political developments in Europe and the Middle East, it included articles on such issues as electricity, barometric pressure and photography. It thus defined itself as a

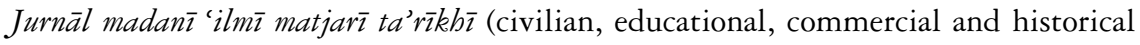
journal). 
In this framework the weekly journal also had a strong interest in the Arabic literary heritage, such as for example the poetic Dīwān by al-Mutanabbī (d. 354/965), which was one of the earliest works to be published by The Syrian Press. Al-Khūrī introduced the idea of serializing texts in a periodical into the Arabic publishing world to provide the readers with books via this new medium. Among the works serialized in The Garden of News were not only classical Arabic works, but also translations of foreign literature, and short stories and poems by the editor and other writers. The first work serialized was Muhammad b. Muhammad Ibn al-Shihna's (d. 815/1412) Rawd al-manāzir fī 'ilm al-awā'il wa-al-awākhir (The Gardens of Sights: Knowledge of the Origins and the Last Things), an annalistic chronicle from the rise of the Saljuqs onwards. ${ }^{33}$ After half a year, however, the serialization was suddenly stopped with the explanation:

Since our start of this newspaper we promised the public [jumbīr] that we will print in its supplement a history by the way of which each subscriber will assemble a book. After efforts we obtained the book by Ibn Shihna and printed some pages of it. We realized nevertheless that the public has not been inclined towards it as it consists of yearly events without a subject which thinking can follow [wa-laysa bi-hi mawdī' yatba'abu al-fikr].

(Hadīqat al-akhbār, Number 27)

The editors had consequently looked for another historical text to serialize, and their decision had fallen on the Rawdatayn since it not only had a subject but also because 'we consider this book to be one of the most splendid Arabic histories since it contains the history of al-Malik al-'Ādil Nūr al-Dīn and al-Malik al-Fāẹil Șalāh al-Dīn'. ${ }^{34}$ After the first part in July 1858, sixteen further parts of the Rawdatayn were published in irregular sequence. ${ }^{35}$ The serialization finally stopped a year later without comment.

Thus, Abū Shāma's Two Gardens found themselves placed in a rather different Garden (of News). A printed version of the Rawdatayn ${ }^{36}$ was, for example, advertised together with other publications by The Syrian Press, which included poetry by al-Khūrī himself, a translated French novel, a guide to commercial laws, a treatise on pregnancy and birth, an introduction to physics, astronomy, anthropology and medicine, and the description of a journey through southern and western Europe. ${ }^{37}$

Khalīl al-Khūrī and The Garden of News belonged to the Syrian-Lebanese reform group, which co-existed with similar groups in other parts of the Ottoman Empire, for example Cairo and Istanbul. All these reform-minded groups implicitly raised the underlying theme of political thought 'What is the good society, the norm which should direct the way of reform?'38 As against other groups, the mainly Christian Syrian-Lebanese reformers were not able to participate directly in the government of the Empire. They expressed their concerns and preoccupations by alternative means of which the newly founded newspapers were a significant part. The printing of the Rawdatayn was not only the result of their fascination with the classical language or their literary taste; it was also included in the newspaper because the work contained 
an underlying 'subject, which thinking can follow.' Abū Shāma depicted ideal rule as a state of affairs belonging to the past, which had been lost in the recent past but which could be revived by the right means. This outlook arguably appealed to thirteenth-/nineteenth-century reform-minded groups seeking alternatives. The depiction of an alternative to the present, which was based on Middle Eastern-Arabic precedents, attracted an intellectual elite, which became increasingly aware of European expansion and was confronted with the question of how to deal with it. Khalīl al-Khūrī himself wrote a novel entitled Woe, then I am not a European in which he addressed the question of how to deal with European influence and of how it is related to traditional ways of life. ${ }^{39}$ This novel addressed the question on a personal level by satirizing his Lebanese-Syrian contemporaries who adopted the European way of life only superficially. The serialization of al-Khūrîs novel in the supplement of The Garden of News replaced the (already quite irregular) publishing of the Rawdatayn. This satirical novel raised the question of how present society should deal with its problems, with an urgency that resembled the underlying theme of Abu Shāma's work.

However, the Rawdatayn had long lost its subversive layer of meaning, which delegitimized the present form of rule. Its transmission and reception in court circles over the preceding centuries had shown that its comment on ideal rule contained layers of meaning which were more easily adaptable to the present form of rules. Its serialization in The Garden of News placed it in a context which was closely connected to the Ottoman governing elite. The newspaper became a mouthpiece of the Ottoman government in the years after its foundation, and Khalīl al-Khūrī himself received a monthly salary. The second printed publication in 1287-8/1871 in Cairo was set in a similar context. The Wādī al-Nīl press, which was also close to the government of its day, published it. Although formally private, it was protected and subsidized by the Khedive Ismā̄îl's government. ${ }^{40}$

The history of the teaching and reception of the Mufarrij and the Rawdatayn shows that these works' early transmission was closely bound to their authors' intentions. While the Mufarrij was read and transmitted in a courtly environment, the Rawdatayn circulated in a scholarly context. Within several decades this difference became increasingly blurred: the Mufarrij continued to circulate mainly in a courtly environment whereas the Rawdatayn was transmitted in both contexts. The Rawdatayn thereby proved to be of longer-lasting popularity. The Mufarrij disappeared from the chain of transmissions within a century of its composition, while the Rawdatayn was copied and transmitted continuously until the thirteenth/ nineteenth century, when it was put into print.

The Mufarrij's emplotment in the mode of Process made it relevant only for a short period after its composition. With the passing of time, it lost this relevance, and was supplanted by works expressing a similar idea for the respective more recent past. On the contrary, the Rawdatayn, emplotted in the mode of Stasis, increased in relevance in the aftermath of its writing. However, the initial subversive message became largely domesticated into a discourse of a romantic past, which was beyond immediate concern for the respective present. Rather than questioning the forms of later rule it 
became so distanced from reality that it served as a description of a better, but inevitably bygone, past. In the thirteenth/nineteenth century its initial message was to a certain degree taken up by groups, which were alarmed by the present state of affairs and which looked for an alternative narrative. Thus, a historical text, which had been written in a revivalist mood found itself - ironically? - on the pages of a modernist newspaper.

The reception of Abū Shāma and the Rawdatayn does not end at this point: In the late twentieth century the text was the subject of a number of studies which stressed an additional layer of meaning. In line with the dominant stream of Arabic historical writing on the sixth/twelfth and seventh/thirteenth centuries in the last decades, ${ }^{41}$ it has been perceived increasingly as an anti-Crusading work. A study of Abū Shāma and his work published in Lebanon, ${ }^{42}$ a modern summary of the work published in Saudi Arabia ${ }^{43}$ and, to a somewhat lesser extent, the introduction to the edition of Abū Shāma's own summary of the Rawdatayn published in Syria in the early $1990 \mathrm{~s}^{44}$ all describe the work as being mainly concerned with the European incursion. The Rawdatayn now appears as a call to reconquer Jerusalem a third time after 'Umar b. al-Khațāâb's conquest in the first/seventh century and Șalāh al-Dīn's reconquest in the sixth/twelfth century. ${ }^{45}$ However, the text's underlying theme on the question of ideal rule has not been lost and its topicality in this regard is specifically underlined:

Abū Shāma [...] compiled for us these resplendent pages of our past and recorded the biographies of these two believing rulers (Nūr al-Dīn Zankī and Șalāh al-Dīn al-Ayyūbī) so that it might be an extended moral lesson and a broad example for whoever wants for himself and his community the Good of this world and of the hereafter. ${ }^{46}$

(Preface by Sa 'î̀ in Mūsā (1999), 3) 


\section{CONCLUSION}

This study has approached medieval Arabic historical writing by focusing on the issue of the authors' room for manoeuvre. At stake were two authors and their texts, situated in seventh-/thirteenth-century Syria and Egypt. Considering the wealth of historical texts during this period of a 'self-confident historiographic tradition', ${ }^{1}$ this discussion is best described as a micro-study with all the inherent problems and merits. While statements on a more general level on Arabic medieval historiography are impossible in this context, the approach and the results of this study alerts the student of this material in general to the complexity of these 'dry' chronicles.

The discussion has shown that these texts are more than somewhat biased, but generally unproblematic representations of the past: they are complex narratives which have to be understood by taking into account the authors' positions in social and intellectual terms. In this way, the study's approach has been at the same time one of its main arguments; an understanding of these texts' meaning demands a simultaneous and detailed consideration of their narrative structures and the social and intellectual contexts of their production. Via the writing of history, the two authors, Ibn Wāṣil and Abū Shāma, discussed a number of issues, which were topical in their period, most prominently the question of ideal rule. This is in contrast to previous evaluations of this period's historical writing, as summarized by Rosenthal at his time:

History was not used as a means for the propagation of ideas, or, more exactly, historians as a rule did not consciously intend, in writing their works, to reinterpret historical data so as to conform to the ideas they might have wished to propagate.

(Rosenthal (1968), 61-2)

Ibn Wāṣil and Abū Shāma not only propagated their ideas quite vigorously, they also strongly argued conflicting visions of the forms of ideal rule. These two authors extensively employed their considerable room for manoeuvre in their writings. Beyond the shared genre and the period they treated, the texts are characterized more by differences than by common features. Ibn Wāṣil wrote an accommodationist text, which basically argued that the present state of affairs is as much a legitimate form 
of rule, as different forms in the past had been, and future forms probably will be. Abū Shāma wrote a reformist text, insisting on the present's despicable state of affairs, and showing the need for drastic changes orientated towards past examples.

The recognition of this multi-layered quality of medieval chronicles leaves a major question: As these texts were structured by modes of emplotment, how can the raw material, or the historical data, still be used? To put it another way, how is it then possible to differentiate between correct and wrong information and to ascertain the 'truth-value' of such texts? Throughout the discussion of the texts in Chapters 5 and 6 it has been obvious that the question of veracity was not at stake. The disregard of this issue in these chapters has not been the outcome of a postmodernist conviction that such questions are generally impossible to decide, or even entirely irrelevant. Rather, it was simply an issue which could not be discussed at this point. The modes of emplotment, the prefigurative decisions by the authors, are beyond verification or falsification. To narrate the material in the mode of Stasis or mode of Process was basically a literary decision that would be impossible to subject to criteria of veracity. As shown in the discussion, the authors did not have to 'falsify' facts in order to convey a certain meaning. Rather, they employed a variety of literary means in order to endow the 'mouldable material', whether true or false, with specific meanings.

In contrast, the mouldable material can and must still be evaluated in terms of its veracity. The analysis of Chapters 3 and 4 was based on the standard source-critical and commonsensical practice employed in the field of history. The texts used for this factual reconstruction of their social and intellectual contexts were indeed similar to the Mufarrij and the Rawdatayn - and even these texts themselves were partly consulted in this vein. Hence, the layers of meaning this study has defined for the texts are by no means the only ways to read the texts. The existence of 'fictional' elements in them does not automatically mean that they are entirely fictional and beyond the criteria of veracity. To identify such fictional elements in these texts merely adds an additional perspective, which is, however, crucial, as it has been hitherto neglected. It was on this level that medieval authors could display their narrative agency, that they were able - to return to the starting point of this study - 'to innovate upon received cultural categories [...] in accordance with their personal and collective ideals, interests, and commitments.' 


\section{APPENDIX}

\begin{tabular}{|c|c|}
\hline b. 604 & 'álim family, Hama \\
\hline $616-24$ & $\begin{array}{l}\text { moving with his father } \\
\text { within Syria, who holds } \\
\text { different positions in } \\
\text { Hama, al-Ma'arra, } \\
\text { Jerusalem }\end{array}$ \\
\hline 624 & $\begin{array}{l}\text { teacher in al-Nāșirīya } \\
\text { Madrasa in Jerusalem }\end{array}$ \\
\hline $627-8$ & in Aleppo \\
\hline 629 & $\begin{array}{l}\text { in al-Karak with } \\
\text { his father }\end{array}$ \\
\hline 630 & $\begin{array}{l}\text { position at court in } \\
\text { al-Karak }\end{array}$ \\
\hline $631-3$ & $\begin{array}{l}\text { position at court in } \\
\text { Hama }\end{array}$ \\
\hline $633-4$ & $\begin{array}{l}\text { position at court in } \\
\text { al-Karak }\end{array}$ \\
\hline $634-7$ & mainly in Damascus \\
\hline 641 & $\begin{array}{l}\text { position at court in } \\
\text { Hama, mission to } \\
\text { Baghdad }\end{array}$ \\
\hline 643 & moves to Egypt \\
\hline 644 & $\begin{array}{l}\text { teacher in al-Aqmar } \\
\text { Mosque }\end{array}$ \\
\hline 647 & at al-Manșūra \\
\hline 649 & pilgrimage \\
\hline 655 & judge in Gìza and Ațfị \\
\hline 658 & $\begin{array}{l}\text { teacher in Zāwiya } \\
\text { Madrasa }\end{array}$ \\
\hline 658 & $\begin{array}{l}\text { refugees from Syria } \\
\text { arrive in Egypt }\end{array}$ \\
\hline 659 & mission to Sicily \\
\hline$\sim 670 s$ & $\begin{array}{l}\text { chief judge in Hama } \\
\text { (until death 697) }\end{array}$ \\
\hline
\end{tabular}

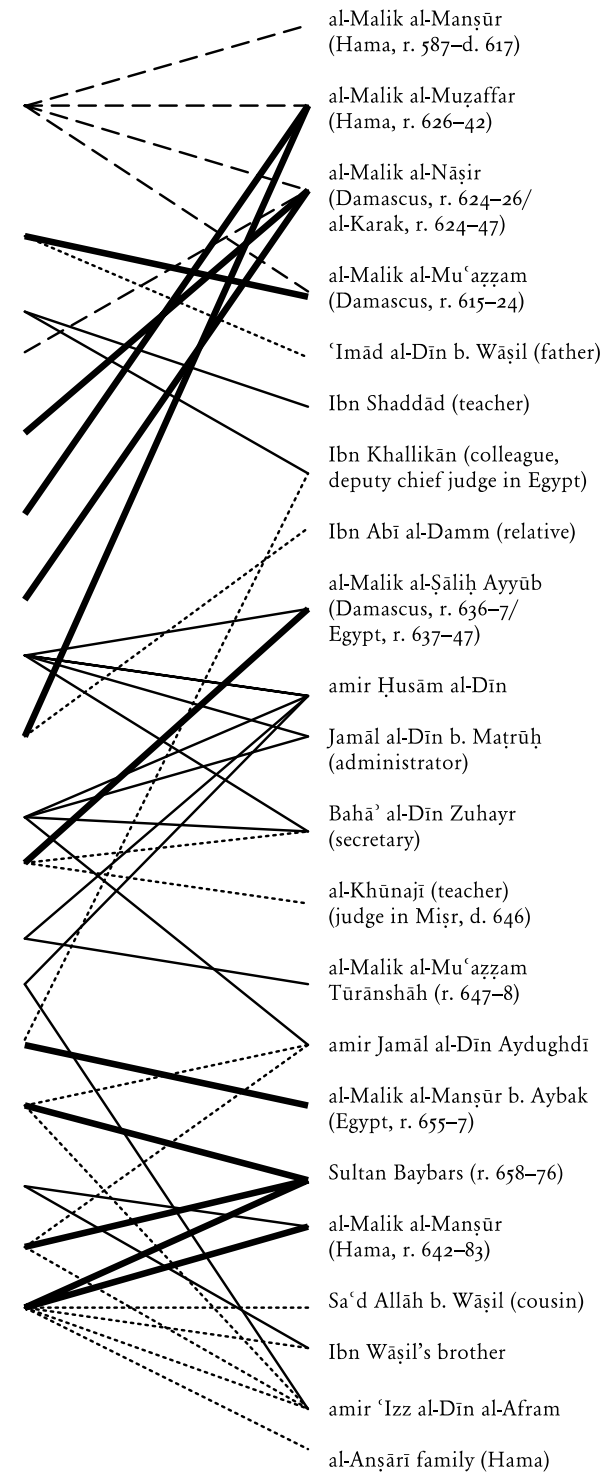

Figure 1 Network Ibn Wāṣil. 
Notes

Bold straight lines ( - ) represent the appointment to a specific post by a ruler. These links are explicitly stated as such in the sources.

Dotted lines (.....) represent the link between Ibn Wāșil's appointment to a post and an individual below the level of rulers who played a rule in this appointment. These links are generally not explicitly stated as such in the sources and represent the main argument of the network approach as applied here.

Normal straight lines (-) signify that Ibn Wāṣil was in contact with the respective individual during the specific event or period.

Dashed lines (- -) represent indirect relationships, that is Ibn Wāṣil became, via his father, acquainted with the rulers during the first two decades of his life.

The representation of links in this figure is not comprehensive. For his period in Damascus in the mid-620s, for example, Ibn Shaddād is named as the only teacher, whereas Ibn Wāṣil studied there also with Ibn Yāīsh (d. 643/1245) and Muhammad b. Abī Bakr Ibn Khabbāz (d. 631/1234). The decision on including or excluding specific individuals depends on their significance to network relationships. In the example here, Ibn Shaddād is mentioned because Ibn Wāṣil and Ibn Khallikān, who played a role in Ibn Wāṣil's subsequent Egyptian years, studied with this teacher at the same time. 


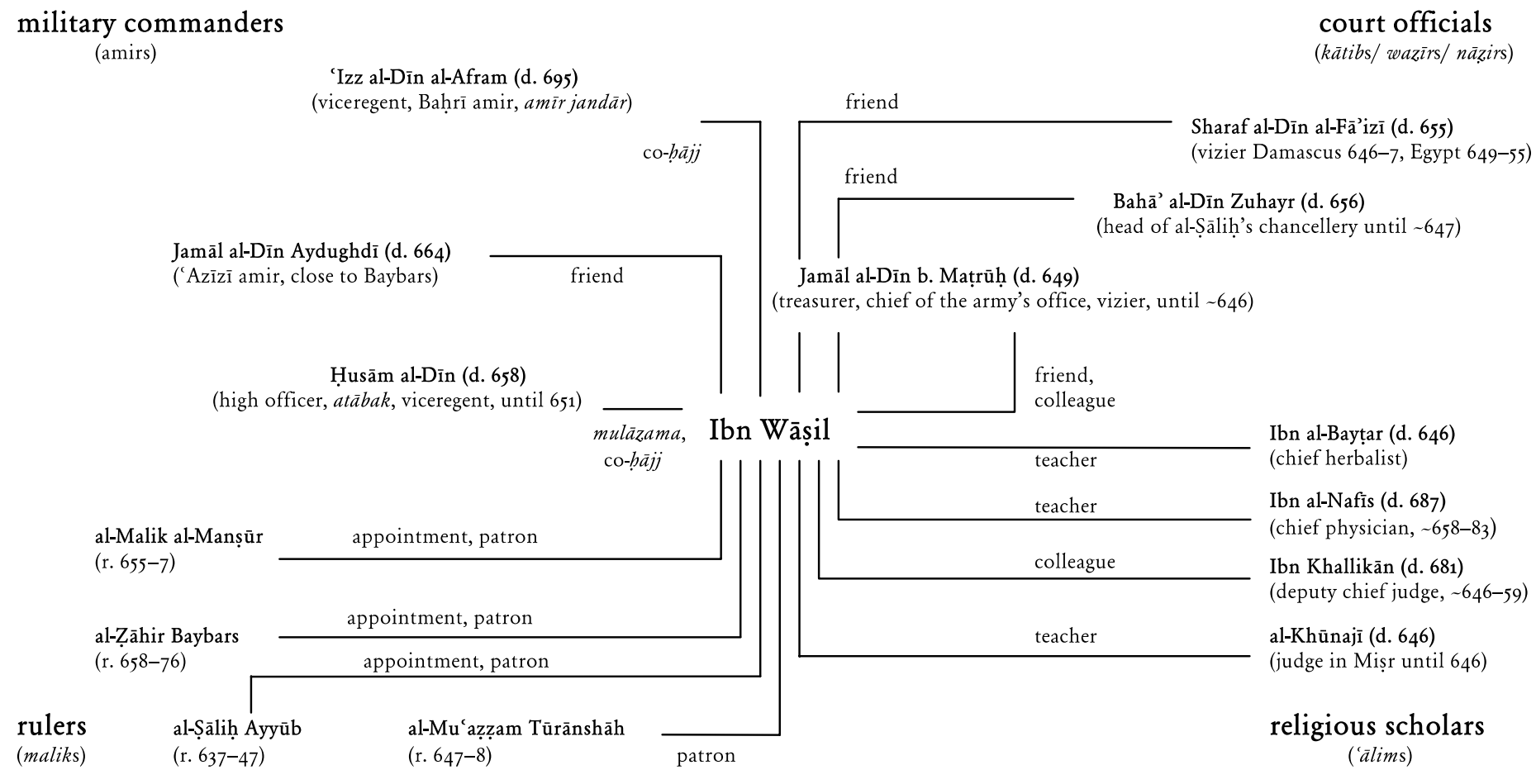

Figure 2 Ibn Wāșil in Egypt (643-early 660s). 


\section{NOTES}

\section{NOTES ON ROMANIZATION AND TERMINOLOGY}

1 However, the $t \bar{a}$ ' marbüta preceded by the long vowel ' $a$ ' is transcribed as ' $t$ ' in all cases, that is, salāt, al-șalät and șalät al-jum'a.

2 Smith (1997).

3 Recent examples of such reflections would be Chamberlain (1994), 25-6, and in more detail al-Azmeh (1998).

4 Noth (1998), 113-19, making the point that a future periodization will be based on research on population groups below the level of the rulers.

5 Hodgson (1974), I, 233-40.

\section{INTRODUCTION}

1 Both texts have been preserved in their entirety. The Rawdatayn has been repeatedly edited since the late nineteenth century and has recently (1997) been re-edited in a decisively more reliable edition. The Mufarrij has drawn less interest and the only existing edition, started in 1953, still awaits completion. The manuscripts for the final sixth volume are preserved in the Bibliothèque Nationale, Paris, arabe 1702 and arabe 1703; their editing (including commentary) is currently being carried out as a doctoral dissertation by $\mathrm{Mr}$ Mohamed Rahim under the supervision of Prof. Seidensticker at the University of Jena, Germany.

2 As, for example, seen in Hillenbrand's (1999) work on the Crusades from an Islamic perspective or in Heidemann's (2002) study of the urban renaissance in northern Syria in the transitional period to the Saljuqs.

3 It is only with the eighth/fourteenth century that documentary material, besides material cited in narrative sources, becomes available to a larger degree. See for example Ernst (1960), Amīn (1981) and Little (1984). On this issue in general, see Chamberlain (1994), 11-21.

4 Morgan (1982).

5 For a discussion of the importance of this paradigm to the concept of an 'Islamic civilization', see al-Azmeh (1998). For a challenge of the closely connected decline paradigm in the field of Ottoman history, see Owen (1975) and Hathaway (1996).

6 Rosenthal (1968), 131. Richter (1933), is similar in this regard.

7 This stress on the origins of the genre was characteristic of earlier writers, too. Goldziher (1895/1969), 365, for example described post-sixth-/twelfth-century historical texts as 'all sweat, no spirit', although his evaluation of this field was still rather positive compared to his harsh judgements on other fields of literary activities.

8 Al-Azmeh (1998), 204-11, argues that this approach has permeated the study of Islamic history in a variety of fields. 
9 The author of the major Arabic historiographical study, Musțafā (1978), adopts a similar framework. He considers the awakening during the sixth/twelfth and seventh/thirteenth centuries not as a consequence of internal developments within Arab society, but of the shock of the arrival of foreign invasions, the Crusaders and the Mongols (Muștafā (1978), I, 274).

10 For a detailed critique of his work and an attempt to define the term 'historical thought', see Conermann (1998).

11 This re-orientation is visible in analyses such as Little (1998) who takes, in contrast to his earlier study (1970), the societal context into consideration.

12 El-Hibri (1999), 216.

13 Earlier examples would be Fähndrich (1973) and (1977) who discusses the relationship between 'factual' and 'illustrative' material in Ibn Khallikān's (d. 681/1282) biographical dictionary; Weintritt's (1992) analysis of al-Nuwayrī's (d. after 776/1374) Kitāb al-ilmām; or Malti-Douglas (1980). Al-Azmeh has made the most explicit proposals regarding the application of literary approaches to Arabic historical texts. In a series of articles (1983, 1984 and 1986b) he underlines the intrinsic narrative characteristics of such texts. The adaptation of literary approaches can also be seen in the changed attitudes of authors such as Haarmann: in a posthumously published article (Haarmann (2001)) he takes up the 'literary turn' as a basis for treating the subject. He discusses a ninth-/fifteenth-century chronicler seriously despite the chronicler's tendency to dwell on episodes/anecdotes, and a rather brisk use of factual material. Franz's (2004) discussion of compilation in medieval chronicles which touches also the issues 'topoi' and 'subtexts' is of rather limited value for the post-formative period.

14 Authors such as Blacker (1994) in his study of twelfth-century historical writing for Anglo-Norman rulers applies a similar approach. Other helpful studies in this context are Partner (1977) and Otter (1996) on twelfth-century historical writing in England, Heinzelmann's (1994) work on Gregory of Tours and Wolf (1995) on eleventh-century historians in Italy writing for the Normans.

15 Spiegel (1993).

16 Spiegel (1993), 96.

17 Spiegel (1997a).

18 Spiegel (1997b).

19 On the increased importance of 'meaning' as a category of analysis, see Daniel (1997).

20 This 'cultural turn' has been particularly visible in the field of microhistory, and the trend away from the histories of great men toward those of 'small' people. Geertz's (1973) Thick Description influenced Darnton (1984) to a large degree, and this influence can also be seen to a lesser degree in studies such as Davis (1983).

21 Geertz (1973), 14.

22 For these developments, see Sewell (1999).

23 Sewell (1999), 44-7.

24 White (1973), p. IX.

25 Wagner (1993), for instance, criticizes White's classification of texts into rigid categories; and Evans (1997), his misunderstanding of the differentiation between 'fact' and 'event'.

26 Kellner (1995), 14.

27 Frye (1967) and (1981), Auerbach (1953).

28 Reynolds (2001), 30.

29 See Chapter 7.

30 This understanding of 'inclusion' is partly based on Quinn (2000), 33-4.

\section{HISTORICAL AND HISTORIOGRAPHICAL BACKGROUND}

1 'Syria' is used here as the translation of 'bilād al-Shām', which includes the modern states of Syria (except the north-eastern part, which belongs to al-Jazìra), Lebanon, Jordan, Palestine and Israel. 
2 See Chapter 5 for a detailed discussion of the texts' final passages.

3 'Al-Jazīra' corresponds roughly to northern Mesopotamia, that is the northern part of the region between the Euphrates and Tigris. It consists of the regions of Diyār Rabī'a, Diyār Muḍar and Diyār Bakr and furthermore includes some regions to the north and the east of the Tigris, such as Mayyāfāriqīn. Thus, in modern geographical terms it includes the north-eastern part of Syria, the south-eastern part of Turkey and the northern part of Iraq, which are largely inhabited by Kurds.

4 This concept of succession had been previously practiced by the Buyid dynasty in parts of Persia and Iraq during their reign in the late fourth/tenth and early fifth/eleventh centuries. However, the Saljuqs are more central to the regions covered in this study as they introduced this style of succession into much wider regions of the Islamic world.

5 Here: Tutor over minor son(s) of the ruler, being responsible for his/their security, education and so on.

6 'Bilād al-Rūm' refers to the former Greek lands of the Byzantine Empire bordering on the south with Syria and al-Jazīra along the Taurus-upper Euphrates frontier region. 'Rūm' was employed in the Arabic literature alternatively for the Romans, Byzantines and the Christian Melkites.

7 Abū Shāma, Rawḍatayn, I, 22: 'After I had spent most of my life-time and my thoughts seeking to acquire the useful lessons of the revelation and avail myself of the gems of literature it occurred to me that I might turn some of my attention to the study of history' ( fa-innahu ba'da an șaraftu jull 'umrī wa-mu'zam fikrī fì iqtibās al-fawā'id al-shar'̄ìya wa-iqtināș al-farā'id al-adabìya 'anna lì an așifa ilā 'ilm al-ta'rīkh ba'dahu).

8 See for example the 1947 edition used in this study: Abū Shāma, Dhayl, 5. The edition is based on one single manuscript (Istanbul, Köprülü 1080) which was copied in $967 / 1560$.

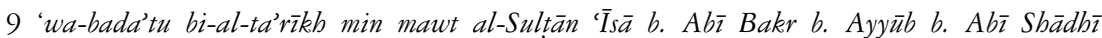
al-mulaqqab bi-al-Malik al-Mu'azzam șābib Dimashq wa-a'mālibā wa-al-Bayt al-Muqaddas wa-a'mālihā ba'da ab̄̄hi al-'Ā dil li-anna ba'dahā jarat umūr shāhadtubā wa-aḅāl 'araftubā wa-huwa al-waqt alladhì khatara lī fìhi tadwīn al-ta'rìkh'. This year 624/1227 constituted indeed a break in the work: whereas Abū Shāma largely reworked in the preceding passages Sibt b. al-Jawzî̀s annalistic chronicle Mir'ät al-zamān, the passages on the following years were generally his own work.

10 Hājjī Khalīfa, Kashf, 294.

11 On al-Nasawī, see Jackson, P. in: EI2 (CD-Rom version) 'al-Nasaw $\bar{\imath}$.

12 On this work and its manuscript, see the introduction to the edition of Abū Shāma, 'Uyūn, I, 139-41.

13 Abū Shāma, Rawḍatayn, II, 222.

14 On this genre, see Daftary (1994).

15 Abū Shāma, 'Uyūn, I, 180.

16 Except: al-Yūnīn̄i, Dhayl, II, 368, and al-Kutubī, 'Uyūn, XX, 353, whose entry depends on al-Yūnīnīs text.

17 Istanbul, Köprülü 1153; BL, or. 1537; al-Rabāt, al-Khizāna al-'Āmma, Nr. 251. For further information on the manuscripts, see the editor's introduction to Abū Shāma, 'Uyūn, I, 143 and 160.

18 A systematic comparison between the Rawdatayn and its summary has not been undertaken here as the autograph manuscript in Istanbul was not used for the only edition of the work. In the two remaining manuscripts, which were used for the edition, the copyist changed, according to his own words, the text and added information (Abū Shāma, 'Uyūn, I, 179).

19 Abū Shāma, Dhayl, 187.

20 Abū Shāma, Rawḍatayn, Leiden Cod. 77 Gol. (reproduced in al-Munajjid (1955)). The note reads: '[...] ākbir al-mujallada al-ūlā min Kitāb al-rawdatayn faragha minhāa 
musannifubā nuskh ${ }^{a n}$ fì 11 Ramadān al-mubārak 651 [1253] wa-ishtamalat hādhibī al-nuskba al-mubayyada 'alā ziyādāt kathīra fātat al-nusakh al-mutaqaddima 'alā hādhibì al-ta'rīkh al-manqūla min al-musawwada wa-kull mā yunqalu min hädhib̄̄ al-nuskba buwa al-aṣl alladhī yu'tamadu 'alaybi wa-yurkanu ilaybi'.

21 Except Ibn al-Ṣābūnī, Takmila, 211-13, and al-Suyūṭī, Bughya, 77-8.

22 See Chapter 7.

23 For a statistical overview of the authors used by Abū Shāma, see Ahmad (1956), 59; for a list of the texts used, see the edition of the Rawdatayn by al-Zìbaq, V, 215-18.

24 Dhayl Ta'rīkh Dimashq, ed. H.F. Amedroz, Leiden 1908.

25 Especially al-Barq al-Shāmī (discussed in Richter-Bernburg (1998) and al-Fath al-Qussī (ed. Landberg (1888) and tr. Massé (1972)).

26 Ibn Khallikān, Wafayāt, BL, Add. 25735, fol. 3a: 'qāla al-faqīr ilā 'afw Allāh wa-rabmatibi Mubammad b. Sālim b. Naṣr Allāh b. Sālim b. Wāṣil: kuntu min mundhu balaghtu al-bilm ilāa al-ān, wa-qad nayyaftu' alà sab'ìn mūlà bi-fann al-ta'rìkh wa [illegible, al-kutub?] al-musannafa fïhi'.

27 Ibn Wāṣil, Șālị̣ī, fol. 8a. On this chronicle, see Cahen (1986).

28 Al-Ṣafadī, Wāfī, III, 85; Ibn Qāḍī Shuhba, Ṭabaqāt, II, 195; al-Suyūṭī, Bughya, I, 108.

29 Besides the manuscript BL, or. 6657, used in this study: Leningrad Musée Asiatique no. 520 and Istanbul, al-Fātih 4224. Only the Istanbul manuscript is complete. The manuscript Gotha arab. 547, which has often been described as a copy of this work is probably wrongly ascribed (Waddy (1934), 120-2). In Chester Beatty Ar. 5264, a manuscript of Ibn Wāșil's universal history Nażm al-durar fī al-tawārikh wa-al-siyar exists, but due to its deteriorated condition it is barely legible.

30 Ibn Wāṣil, Șāliḥ̄i, fol. 8b: 'ta'rīkh mutawwal yabsutu al-qawl fīhā ghāyat al-bast hattā an lā

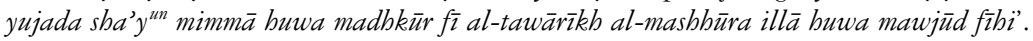

31 Ibn Wāṣil, Mufarrij, I, 204 and 236.

32 Exception: al-Ṣafadī, A'yān, IV, 1662, who mentions besides his Mufarrij and The Saalibịian History, 'al-ta'rīkh alladbī la-bu'.

33 Such large universal histories were typical for the period. To take just early seventh-/ thirteenth-century Hama, we find two authors writing similar works: Ibn Wāṣil's maternal relative Shihāb al-Dīn Ibn Abī al-Damm (see references in Chapter 3; and on his historical work Richards (1993b)) and the court official Muhammad b. 'Alī b. al-Nazīf (d. after 634/1236-7) (see Doudou (1981) and Hartmann (2001), 96). Their grand universal histories have also been lost but, as with Ibn Wāṣil's Șälibiaian History, their shorter universal histories, which were dedicated to rulers, have survived.

34 Al-Dhahabī, Ta’rīkh, years 661-70, 299.

35 Waddy (1934), $143 \mathrm{ff}$.

36 Midmār al-haqa'̄iq wa-sirr al-khalā’’iq, ed. Hasan Habashī, Cairo 1968.

37 On him, see Chapter 3.

38 On Ibn al-Athīr, see Rosenthal, F. in: EI2 'Ibn al-Athīr'; Gibb (1950); Ahmad (1962); Rosenthal (1968); Richards (1982).

39 Al-Nawādir al-sulțānīya wa-al-mahāsin al-Yūsufīya. On Ibn Shaddād, see al-Shayyal, G. in: EI2 'Ibn Shaddād'; Richards (2001), 1-6.

40 Zubdat al-halab fì ta'rīkh Halab. On Ibn al-'Adīm, see Lewis, B. in: EI2 'Ibn al-'Adīm'; Morray (1994).

41 Mir'āt al-zamān fì ta'rīkh al-a'yān. On Sibț Ibn al-Jawzīe see Cahen, C. in: EI2 'Ibn alJawzì'.

42 However, Ibn al-Athīr authored other works (including one on the companions of the Prophet, Usd al-ghāba fì márifat al-șabāba), which certainly do not fit into a differentiation between religious and political historical works.

43 Morray (1994), 10-11.

44 Khalidi (1994), 182-4. 


\section{SOCIAL CONTEXTS}

1 On Ibn Wāșil, see references in al-Dhahabī, Ta’rīkh, years 691-700, 337-8, and in addition: al-Yūnīn̄i, Dhayl, ed. Guo, 28; al-Subkī, Tabaqāt, VIII, 134-5; al-Asnawī, Tabaqāt, II, 554-5. The most comprehensive study on him is, the quite descriptive, Waddy (1934), with Waddy (1972), attempting to place his main chronicle, the Mufarrij, into a wider picture. Of interest on his life is also al-Shayyal, G. in: EI2 'Ibn Wāșil'. I did not gain access to al-Shayyal's PhD Thesis (University of Alexandria 1948). On the factual value of his text, see Cahen (1940), 69-70, Ahmad (1962), 94-5 and Elisséeff (1967), 7, 61.

2 On the issue of dedications, see Touati (2000), who focuses on the third/ninth and fourth/tenth centuries.

3 Ibn Wāșil, Mufarrij, Paris BN, arabe 1703, fol. 90a.

4 For this work, see Chapter 4. On his stay at the court, see Ibn Wāṣil, Mufarrij, IV, 234 and 248-51; Abū al-Fidā', Mukhtașar, IV, 38-9; Gabrieli (1956).

5 For example Muhammad al-Idrīsī (d. 560/1165?), who wrote the Arabic geographical compendium, Liber Rogeris/Kitāb Rüjar, which he completed in 548/1154 for the Norman ruler Roger II. On these intellectual exchanges, see Halm (1991), 214-16.

6 For example: Elisséeff (1967), 7.

7 'yā sayyid" lā zāla najm" sa'dibilf $\bar{\imath}$ falak ${ }^{i}$ al-'uly $\bar{a}$ ' ya'lū al-anjumā

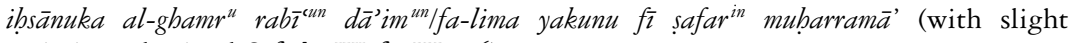
variations also in al-Ṣafadī, Wā̄īi, III, 86).

8 For the difference to both contexts, see for example Chamberlain (1994), especially the introduction, and specifically for the Chinese context Lapidus (1975).

9 Earlier scholarship was to a certain degree influenced by the eighteenth- and nineteenthcentury ideas of 'Oriental Despotism' (Montesqieu) or the 'Oriental Mode of Production' (Marx). For a discussion of this, see Chamberlain's (1994) introduction and Arjomand (1999).

10 For example Watt (1963), 157, who argues, for modern and pre-modern periods alike: 'Many of the troubles of the Islamic world can be traced to the rulers' domination of the intellectuals and the latter's subservience to the rulers'.

11 Rosenthal (1968), 62.

12 The assumption that authors had hardly any room for manoeuvre in their writings, but had to closely follow the outlook of the respective patron, is a salient feature of Quinn's (2000) discussion of Safavid chronicles between the eighth/fourteenth and the eleventh/seventeenth centuries.

13 Havemann (1975), who discusses the question of urban autonomy in Syrian towns between the fourth/tenth and sixth/twelfth centuries with a focus on the questions of urban institutions.

14 For the Egyptian context of the development of the madrasa, see Leiser (1976).

15 Gilbert (1977) shows this development in the context of the sixth/twelfth and seventh/thirteenth century in Damascus.

16 For example Leiser (1976) and Arjomand (1999). The development of madrasas has also been seen in the framework of the Sunni revival as a tool to combat Shiism; see for example Tabbaa (1997), 125-7, and Hillenbrand, R. in: EI2 'madrasa' (subsection 'architecture').

17 The prime example here is Makdisi (1981), with a continuation for the Mamluk periods by Arjomand (1999).

18 For example Arjomand (1999), who argues that during the Saljuq period a major shift occurred in the basis of social agency from 'civil society' to the 'patrimonial state'.

19 Pedersen, J./[Makdisi, G.] in: EI2 'madrasa' (part I); Berkey (1992) and Chamberlain (1994) also refute the central role of the state, but stress that this question ignores the blurred distinction between 'private' and 'public' in these periods. 
20 For example Chamberlain (1994) in the framework of his overall argument that the study of medieval Middle Eastern history in general demands a shift away from structures towards social practices. Ephrat (2000) argues a similar point in her study on scholarly networks in fifth-/eleventh-century Baghdad.

21 Here Berkey (1992) and Chamberlain (1994) are decisive for the period covered in this study.

22 Paul (1996), 12-13 and 162-79.

23 For an overview and critical assessment of this approach, see Emirbayer/Goodwin (1994).

24 Helpful items for the application of the 'network-concept' in the Islamic context are Sato (1997); especially Miura (1997) for the Mamluk context; Loimeier/Reichmuth (1996); and the publications of the working-group Islamic Education Networks at the Ruhr-Universität Bochum under Michael Kemper. For an application of this concept in different settings within the Islamic world, see Loimeier (2000).

25 Lapidus (1975), which represents in this regard the turning point in the field of Islamic history. In this study he moves the term 'network' away from the linked negative connotation of illegitimacy. Nevertheless, it is still clear that he associates the term with ideas such as instability. On the contrary, the anthropological essays, especially Rosen's contribution, in Geertz et al. (1979), on Moroccan society argue for the crucial importance of networks for understanding society's structure.

26 Rosen (1979) is exemplary here: he shows how different formal aspects, such as formal offices and legal prerogatives are employed as resources, and can be tapped for specific ends.

27 Makdisi (1981), 128.

28 Mottahedeh (2001), for example, mainly limits his relevant chapter on 'acquired loyalties' to members of the immediate ruling elite (khawāṣ as opposed to ra'izya/subjects).

29 Ibn al-Ṣua $\bar{a}^{-} \overline{1}$, Tālī, $47-8$, no. 72.

30 Berkey (1992), 34.

31 Ibn al-Ṣuqā' $\overline{1}$, Tālī, 180, no. 301.

32 Ibn al-Ṣuqā̄ $\overline{1}^{-}, T_{a}{ }^{1} \overline{1}, 14-15$, no. 20.

33 For example the administrator Nāṣir al-Dīn Dhubyān who derived his nisba 'al-Shaykhī' from 'Abd al-Raḥmān al-Kawāshī in whose șuḅba he had come to Syria. (Ibn al-Ṣuqā'̄̄, Tālīi, 73, no. 110).

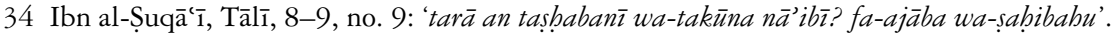

35 Ibn Khallikān, Wafayāt, II, 338: 'mawadda kānat baynanā'.

36 Al-Makdisi (1981), 128-9, with Berkey (1992), 34-5, largely following his line of argument.

37 Ibn al-Ṣuqā̄ì, Tālì, 144-5, no. 235.

38 Ibn Wāṣil describing his relationship to the ruler of al-Karak, al-Malik al-Nāṣir Dāaùd. (Ibn Wāṣil, Mufarrij, V, 35 and 112).

39 Ibn Wāṣil, Mufarrij, V, 209: 'wa-kāna hādhāni al-rajulān [...] min atamm al-nās murü'at ${ }^{a n}$ wa-i'tināan bi-man yalūdhu bi-himā wa-yașhabubumàa'.

40 Al-Ṣafad̄̄, Wāfīi, XIV, 231-43.

41 Ibn al-Ṣuqā̄ī, Tālī, 66, no. 101: 'wa-yakhfuru man yașhabubu wa-yamīrubu'.

42 Also called al-Madrasa al-Șalāhīya. On this madrasa, see al-Nu'aymī, Dāris, I, 331-3.

43 Ibn Wāṣil, Mufarrij, IV, 208.

44 Ibn Wāṣil, Mufarrij, Paris BN, arabe 1703, fol. 122a.

45 Here, place of teaching within a mosque similar to a madrasa's function. This zäwiya enjoyed prestige due to previous post-holders such as 'Alī b. Hibat Allāh al-Jumayzī (d. 649/1252) the 'ra'šs al-'ulamā' ' in Egypt (al-Subkī, TTabaqāt, VIII, 301-4).

46 Ibn Wāṣil, Mufarrij, Paris BN, arabe 1703, fol. 84b.

47 See for example al-Ṣafadī, Wāfí, III, 85-6, on a scholar who received from him a licence to teach (ijāza) in 690/1291 when Ibn Wāșil accompanied his ruler on a mission to Egypt in the early 690s/1290s, or al-Malik al-Ṣālih al-Mu’ayyad Abū al-Fidā' (d. 732/1332), the later ruler of Hama, who attended his study circle (Abū al-Fidāa , Mukhtașar, IV, 38).

48 A similar short review forms the core of the article by al-Shayyal, G. in: EI2 'Ibn Wāsil'. 
49 Ibn Wāṣil, Mufarrij, V, 344: 'bulūgh al-āmāl kullihăa'.

50 Ibn Wāsil, Mufarrij, V, 333.

51 Built in 519/1125 under the Fatimids. Although it was called a congregational mosque (jammi $i^{\prime}$ the Friday sermon (kbutba) was not held in it during the Ayyubid period, thus during this period it was, rather, a masjid. Teaching took place in it for long periods after Șalāh al-Dīn had endowed the teaching position. (al-Maqrīìì, Khițaț, III, 253-5). On the decree, see el-Beheiry (1974).

52 Bierman (1998), 103 and 134-9; MacKenzie (1986), $245 \mathrm{ff}$.

53 On 'Abd al-'Azīz, see Ibn Shaddād, A'lāq, 99-100 and al-Nu'aymīè, Dāris, I, 279.

54 On the Banū 'Așrūn, see Eddé (1999), 382-3.

55 One of the assistants of nāzir bayt al-māl, the treasurer, besides shubūd bayt al-māl, kātib bayt al-māl and sayrafî̀ bayt al-māl. The treasurer administered the bayt al-māl whose function was to receive and distribute the surplus of the other dīwains.

56 Al-Dhahabī, Ta’'rīkh, years 631-40, 406.

57 Ibn Wāșil, Mufarrij, Paris BN, arabe 1703, fols. 69b and 70a. It is the only decree of nomination for such a post which has survived from the Ayyubid period in Egypt.

58 The passage regarding his appointments reads: 'fa-lamm $\bar{a}$ tuwuffiya talaba al-tadrīs bi-bādhā al-makān jamā'a min al-a'yān fa-lam yasmub al-Malik al-Sāliḅ bi-tawliyat aḅad minbum la-bu, wa-lammā dhukirtu lil-Malik al-Șälịh rabimabu Allāh amara bi-an yuwuqqi`a lī bi-hi' (Ibn Wāṣil, Mufarrij, Paris BN, arabe 1703, fol. 70a).

59 On Fakhr al-Dīn, see al-Dhahabī, Ta’rīkh, years 691-700, 188-9.

60 The chancery or bureau of official correspondence ( $d \bar{\imath} w \bar{a} n$ al-insh $\bar{a}$ ) played a crucial role since it was also responsible for administering the polity's external and internal affairs. In addition, it supplied the main information determining the future course of policies (see Humphreys (1977), 19-20).

61 Ibn al-Ṣuqāìi, Tāalì, 8-9, no. 9.

62 On Ḥusām al-Dīn, see al-Yūnīnī, Dhayl, I, 384-5; al-Dhahabī, Ta’rīkh, years 651-60, 377-8; al-Ṣafadī, Wāfī, XXII, 102; Ibn Taghrībirdī, Nujūm, VII, 5 and 93; Humphreys (1977), 250-1.

63 Ibn Wāṣil, Mufarrij, V, 208.

64 An amir, who received the responsibility for the ruler's household (managing supplies, control of court retinue and servants), held this post. During the early Mamluk period, particularly under the sultan Baybars (r. 658/1260-676/1277), the post gained in responsibilities, taking charges which had hitherto been fulfilled by the vizier (control of treasury and administration).

65 Representative of the sultan. This office existed during the Ayyubid period based on ad hoc appointments and became increasingly formalized under the Mamluks, especially during the reign of sultan Baybars. As the office gained importance to the detriment of the position of the vizier, the holders of these two posts often came into conflict. At the end of the seventh/thirteenth century the $n \bar{a}^{\prime} i b$ had finally become more powerful than the vizier (Chapoutot-Remadi (1993), 123ff.). At the same time the term referred during the Mamluk period to the highest official in the subdivisions of the Mamluk realm (mamlaka), who commanded the military, religious and administrative officers.

66 Ibn Wāṣil, Mufarrij, V, 242-3. Ibn Wāṣil described repeatedly the harsh treatment to which Husām al-Dīn was subjected in captivity (Ibn Wāṣil, Mufarrij, V, 328-9, 362).

67 On Jamāl al-Dīn, see Ibn Khallikān, Wafayāt, VI, 258-66; al-Dhahabī, Ta’rīkh, years 641-50, 433-5; al-Kutubī, 'Uyūn, XX, 54-61; Waddy (1934), 69ff.; Rikabi (1949), 105-20; Rabie (1972), 147-8; Humphreys (1977), 251.

68 Ibn Wāṣil, Mufarrij, Paris BN, arabe 1703, fol. 73a: 'wa-kāna lì bi-bi uns" kathì̀r ${ }^{u n}$ wa-ijtama'tu bi-bi ijtimā'āt kathīra'.

69 Ibn Khallikān, Wafayāt, VI, 263: 'wa-kānat baynahu [Jamāl al-Dīn] wa-bayna Babā'

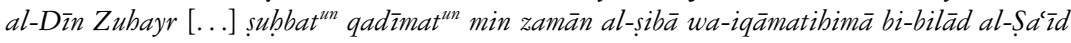
hattā kānā ka-al-akhawayn'. 
70 On Bahā' al-Dīn, see Ibn Khallikān, Wafayāt, II, 332-8; al-Dhahabī, Ta’rīkh, years 651-60, 250-4; al-Ṣafadī, Wā̄ī, XIV, 231-43; al-'Ayn̄̄, 'Iqd, I, 186-7; Ibn Taghrībird̄̄, Nujūm, VII, 62-3; Rikabi (1949), 121-64 and Bahā’ al-Dīn's own Dīwān.

71 Ibn Khallikān, Wafayāt, II, 332-3: 'wa-kāna mutamakkinn" min șāhibibi kabīra al-qadr 'indabu, là yutli'u' alà sirribi al-khafì ghayrahu'.

72 Ibn Wāṣil, Mufarrij, Paris BN, arabe 1703, fols. 70b and 137b. Not in Ibn Wāṣil, Mufarrij, Paris BN, arabe 1702.

73 For al-Ṣaliḥ̣’s early career in Damascus, see Humphreys (1977), 250-65.

74 Ibn Wāṣil, Mufarrij, Paris BN, arabe 1703, fol. 84b.

75 Ibn Wāṣil, Mufarrij, Paris BN, arabe 1703, fol. 145b and Paris BN, arabe 1702, fol. 391b: 'wa-taqaddama Sayf al-Dīn Qutuz bi-jam' al-fuqahà' wa-al-qudā wa-al-a'yān li-mushāwaratibim fìmā ya'tamidu 'alaybi fī amr al-tatār'.

76 Ibn Wāṣil, Mufarrij, Paris BN, arabe 1703, fol. 83a.

77 Ibn Wāṣil was cited as the only teacher in the ruler's biography (al-Subkī, Ṭabaqāat, VIII, 134-6).

78 Ibn Wāṣil, Mufarrij, Paris BN, arabe 1703, fol. 110a; Ibn al-Suqā̄ $\overline{1}$, Tālīi, 13-14, no. 19; al-Ṣafadī, Wāfî̀, IX, 478; Ibn al-Furāt, Ta’rīkh, VIII, 215-16; Ibn Taghrībirdī, Manhal, III, 130-2; Ibn Taghrībirdī, Nujūm, VIII, 80-1; Garcin (1969), 48-51; Thorau (1987), 63. The iqtă $\bar{a}^{c}$ was an assignment, mainly to military commanders, who could dispose of all or part of its income. An iqtă' could consist of land, but could also take other forms such as the tax-income of a certain branch of the administration.

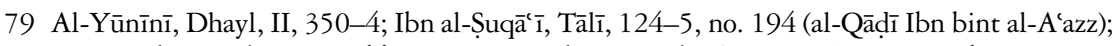
al-Dhahabī, Ta’'īkh, years 661-70, 172-3; Ibn Taghrībirdī, Manhal, III, 159-63.

80 On this matter and also the role of Jamāl al-Dīn, see Escovitz (1984), 20-8.

81 Ibn Wāṣil, Mufarrij, Paris BN, arabe 1703, fols. 113a-116b.

82 Abū Shāma, Dhayl, 196; al-Dhahabī, Ta’rìkh, years 651-60, 220-1; Ibn Kathīr, Bidāya, XIII, 212; Ibn Taghrībirdī, Nujūm, XI, 58; Humphreys (1977), 298-302; Thorau (1987), 65; Chapoutot-Remadi (1993), 137ff. On their relationship: Ibn Wāṣil, Mufarrij, Paris BN, arabe 1703, fol. 119b: 'He was very inclined towards me.' (wa-kāna yamīlu ilayya kathī $r^{a n}$ ).

83 Except for the heated learned discussions he led with Ibn al-Nafiss, see Chapter 4.

84 See further down for the time he spent in Hama with 'Alam al-Dīn Qaysar.

85 For Aleppo, see Eddé (1999). A similar tendency to hereditary succession also existed in other towns such as Damascus.

86 Three members of the al-Bārizī family held the chief judgeship in Hama for some 60 years in the period after 652/1254-5: Ibrāhīm b. al-Musallam b. Hibat Allāh (652-69, see al-Dhahabī, Ta’rīkh, years 661-70, 276), 'Abd al-Rahīm b. Ibrāhīm b. Hibat Allāh (669-670s, see al-Ṣafad̄̄, Wāfī, XVIII, 317-19), Hibat Allāh b. 'Abd al-Rahīm b. Ibrāhīm b. Hibat Allāh (699-mid-730s, see Abū al-Fidā', Mukhtașar, IV, 124).

87 Ibn Wāṣil, Mufarrij, IV, 64-5.

88 Ibn Wāșil, Mufarrij, IV, 141-2.

89 On Shihāb al-Dīn Ibn Abī al-Damm, see Abū al-Fidā’’, Mukhtașar, III, 173; al-Dhahabī, Ta’rīkh, years 641-50, 112; al-Ṣafadī, Wāfī, VI, 33-4; al-Subkī, Ṭabaqāt, VIII, 115-18; al-Asnawī, Țabaqāt, I, 546-7; Humphreys (1977), 262.

90 Ibn Wāṣil, Mufarrij, V, 323-6.

91 Ibn Wāṣil, Mufarrij, V, 227; al-Dhahabī, Ta’rīkh, years 671-80, 130; 'Īsā (1942), 203.

92 Al-Yūnīnī, Dhayl, III, 94.

93 Ibn Wāssil's brother came to Egypt with the ruler, with whom he was on good personal terms ('uns kathīr'), fleeing the Mongol invasions in 658/1260 in Syria (Ibn Wāṣil, Mufarrij, Paris BN, arabe 1703, fol. 160a).

94 Abū al-Fidā', Mukhtașar, IV, 38-9.

95 On him cf. the editor's introduction to the edition of Ibn Mughayzil's Dhayl. 


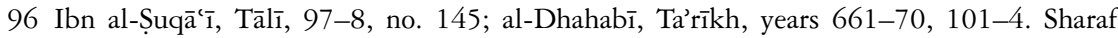
al-Dīn was particularly fond of his grand-son 'Alī b. 'Abd al-Rahim (Ibn al-Mughayzil, Dhayl, editor's introduction, 10/11).

97 Supreme post in the Sufi milieu of a town but transcending in importance and influence this milieu since it is comparable to the prestigious posts of $q \bar{a} d \bar{\imath}$ and khat $\bar{\imath} b$ (Pouzet (1991), 213-16, on the post in Damascus).

98 The paternal grandfather of 'Alī b. 'Abd al-Rahīm, Ahmad (d. 687/1288) was also shaykh al-shuy $\bar{u} k h$ and was furthermore a renowned teacher and mufti (al-Dhahabī, Ta'rīkh, years 681-90, 290-1). Among Ahmad's brothers 'Abd al-Ghuffār (d. 688/1289) was secretary at the court, and 'Abd al-Latîif (d. 690/1291) a respected khațīb, teacher and mufti (al-Dhahabī, Ta'rīkh, years 681-90, 333 and 418-19). On the al-Mughayzil family cf. Ibn al-Mughayzil, Dhayl, editor's introduction, 15-23.

99 On Abū Shāma, see references in al-Dhahabī, Tảrīkh, years 661-70, 196-7; in addition: Ibn al-Jazarī, Qurrā', I, 365-6. Among the modern sources on him the following focus mainly on manuscripts and the factual source-value of his texts: Wüstenfeld (1882), 132-3; Cahen (1940), 66-7; Brockelmann (1949), I, 317 and Supplement I, 550-1; al-'Azzāwī (1957), 84-6; Elisséeff (1967), 51-4; al-Munajjid (1978), 100-3, 443. More information on his social and intellectual contexts contain: Ahmad (1951); Ahmad (1956); Ahmad (1962); Ahmad, H. in: EI2 'Abū Shāma'; Pouzet (1975), 170-2; Altıkulaç (1975); Pouzet (1985/86); Lowry (1997).

100 On him, see al-Dhahabī, Ta'rīkh, years 641-50, 192-6, and the sources quoted there.

101 Abū Shāma, Dhayl, 177.

102 Abū Shāma, Rawḍatayn, I, 25.

103 Another example would be Ibn Kathīr's statement that Abū Shāma 'defamed and criticized' Aḥmad b. Yahyā Ibn Sanī al-Dawla (d. 658/1260), who held the chief judgeship of Damascus for fifteen years (Ibn Kathīr, Bidāya, XIII, 237: 'wa-lākinna Abū Shāma yanālu minhu wa-yadhummubu').

104 Abū Shāma, Dhayl, 43: 'wa-kāna al-musannif 'afā Allāb 'anbu mubibban lil-'uzla wa-al-infirād, ghayr mu'aththir lil-taraddud ilā abwāb abl al-dunyā, mutajanniban al-muzāhama 'alā al-manāsib'. This image was repeated in one of his poems cited by al-Kutubī, 'Uyūn, XX, 354: 'I do not take refuge at a door other than his [God].' ('wa-innanì là alja'u ilā bāb ghayribi').

105 Cook (2000), 126.

106 Abū Shāma, Dhayl, 138: 'ihmad Allāh tá ālā anna fì bilādika wa-fì zamānika man imtana'a min wilāyat al-qad̄à' wa-ikhtāra al-khurūj min baladihi 'alā tawliya dīn ${ }^{a n}$ wa-zubd ${ }^{a n}$.

107 Al-Subkī, Țabaqāt, VIII, 179-83.

108 Chamberlain (1994), 101-6.

109 Pouzet (1991), 113-18.

110 Cook (2000), 124-6.

111 However, his opposition to posts financed by endowments was not unequivocal since he stated that the madrasas were an example of the 'good innovations' (al-bida' al-basana) (Abū Shāma, Bā'ith, 23).

112 'lā tuzāhim wa-lā tukāthir bi-mā ta'kbudhulminhu fa-qad' 'arafta 'l-amrāa

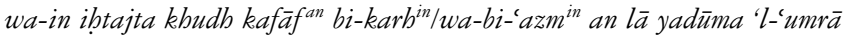
Kāna min qablinā a' immat" bādha 'l-dīni ${ }^{i} w a-l-w a q f^{\prime}$ ba'd dhālika 'staqarrā lam yakun dhäka mānican tāliba al-ilmi/min al-ilm fa-qif dhäka 'l-atharā [...] șadaqāt" 'l-wuqūfi yanfiru minhāalkull' burrin ta'tz̄hi șafw' wa-yusrā

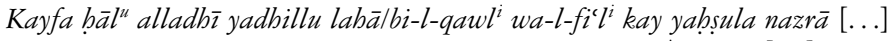

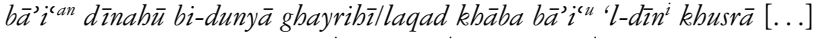
șānañ 'llāh" 'an muzāhamat ${ }^{i} / a l-q a w m^{i}$ 'alā manșibin fa-yā rabbi șabrä'.

113 Al-Dhahabīi, Ta’rīkh, years 651-60, 416-19; al-Ṣafadī, Wāfì, XVIII, 520-2; al-Yāfí̀̄, Mir'āt, IV, 153-8. 


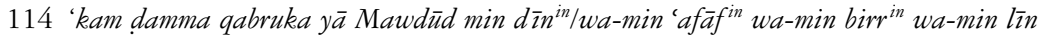
mä kunta taqrubu sultāan ${ }^{a n}$ li-takbdumahulläkinna ghanìta bi-sulțān ${ }^{i}$ al-salātīn'.

115 Al-Dhahabī, Qurrā', II, 673-4: 'kāna ma'a fart dhakā'ibi wa-kathrat 'ilmibi mutawādictin mutarrib $^{a n}$ lil-takalluf' (similarly al-Kutub̄̄, Fawāt, II, 270; al-Ṣafadī, Wāfī, XVIII, 114-15; al-Asnawī, Tabaqāt, II, 118-19 and others).

116 For example, al-Dhahabī, Ta'rīkh, years 651-60, 417: 'tark al-takalluf'.

117 Al-Asnawī, Țabaqāt, II, 198: 'yuhīnu al-mulūk'.

118 Ibn Qāḍ̄ Shuhba, TTabaqāt, II, 109: 'ijtanaba al-thanā' 'alā al-mulūk'.

119 For example on the issue of tolerating wine consumption: al-Subkī, Tabaqāat, VIII, 211-12.

120 The most comprehensive entry on him in the primary sources was al-Subkī, Tabaqāt, VIII, 209-55.

121 Abū Shāma, Dhayl, 37: 'lazima al-iqāma bi-Dimashq 'ākifan 'alā mā huwa bi-șadadibi min al-ishtighāl bi-al-îlm wa-jam'ibi fī mu'allafātibi wa-al-qiyām bi-fatāwā al-abkām wa-ghayrib $\vec{a}$.

122 Abū Shāma, Dhayl, 216; al-Nu'aymī, Dāris, I, 253.

123 Abū Shāma, Dhayl, 230; al-Ṣafadī, Wāfī, XVIII, 116. The prestige of this institution was also due to the relic of the Prophet (al-athar al-nabawn), which was held in it. On this dār al-hadìth, see al-Nu'aymī, Dāris, I, 19-47.

124 Abū Shāma, Dhayl, 199, in the obituary notice for Shams al-Dīn Mahmūd (d. 656/1258), who 'replaced me in the ritual prayers in al-Madrasa al-'Ádilìya during my absence due

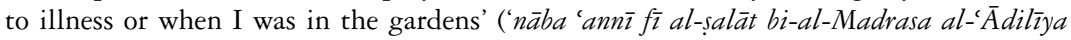

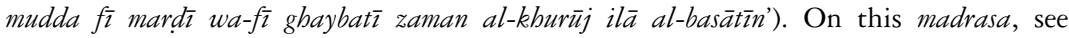
al-Nu'aymī, Dāris, I, 359-67 (al-Madrasa al-'Ādilīya al-Kubrā) and Shumaysānī (1983), $129-35$.

125 Abū Shāma, Dhayl, 149, 164, 179, 186, 189 and 195. In the absence of contrary material it is sound to assume that he spent most of this period there.

126 Abū Shāma, Rawḍatayn, II, 264.

127 Ashtor (1969), 262.

128 The endowment provisions were cited in al-Subkī, Fatāwā, II, 108-12. The income of the shaykh remained seemingly constant in the century after the endowment because the budget for the year 745/1344-5 (al-Subkī, Fatāwā, II, 114) still assigned ninety Dirhams to this post.

129 Ashtor (1971), 104.

130 For example, the teaching position for Quran reading in the Turba Umm al-Ṣaliḥ, which was barred to him due to the condition set out in the endowment (Ibn al-Jazarī, Qurrä', I, 366).

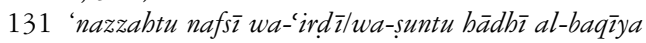

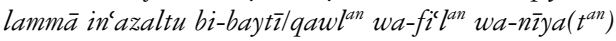

wa-baqqaytu 'ulqat̄i bi-lal-madāris' al-fiqhīya wa-sawfa akblusu minhälbaqq ${ }^{\text {an }}$ wa-rabb al-barīya'.

The passage is however not unequivocal. The decisive line is reproduced in RHC Or, V, 210 (ar.) and 215 (fr.), as: 'I will be dedicated to it [i.e. the knowledge in schools]/I swear it by the Master of the creation.' The difference is linked to the reading of the verb in form I, akblusu or form IV, akblisu (to dedicate/be loyal to). The following preposition min renders the first reading more probable.

132 Yāqūt, Mujam, V, 1963-4, who stated that he was tutor of the children of the amir Ibn Mūsak (d. 644/1246), which, for reasons of age, is improbable. The amir Mūsak (d. 585/1189) was a maternal cousin of Șalāh al-Dīn and his son Ibn Mūsak (d. 644/1246-7) a high officer. On them, see: Sibț Ibn al-Jawzī, Mir'āat, VIII(2), 765-6; al-Dhahabīi, Ta’rīkh, years 641-50, 251; al-Kutubī, Fawāt, II, 65-6; Ibn Taghrībirdī, Nujūm, VI, 110. 
133 Ibn Kathīr, Bidāya, XIII, 181-2.

134 Abū Shāma, Dhayl, verses on 223-4.

135 Abū Shāma, Dhayl, 167.

136 Gilbert (1977), 73ff., for the period between 630/1232-3 and 669/1270-1.

137 Abū Shāma, Dhayl, p. 222, 1. 6: 'mushba' al-abl wa-al-aqārib wa-al-al/zām minhā fa-laysa yashkēuna faqrāân').

138 Abū Shāma, Dhayl, 209.

139 Al-Yūnīnī, Dhayl, II, 368, and al-Kutubī, 'Uyūn, XX, 355.

140 Cf. Abū Shāma, Dhayl, 37, for information on his ancestors.

141 Abū Shāma, Dhayl, 37.

142 Pouzet (1985/86), 116-17.

143 Pouzet (1975), 171-2 and 183.

144 Muhammad b. al-Walīd al-Ṭurțūshī (d. 520/1126) (Fierro (1992), 208-11). On Abū Shāma's treatise, see Chapter 4.

145 Such as Karīma bint Ibn 'Abd al-Wahhāb al-Qurashīya (d. 641/1243), to whom he read from a hadìth work (Leder et al. (1996), 118).

146 In a reading of the Rawdatayn to Abu Shāma in 664/1265, for example, 3 of the attending 6 students belonged to this group: Ibn Farah al-Ishbilī (Seville), Zayn al-Dīn al-Qurțubī (Cordova) and Ismā̄̄îl al-Mālikī (notice reproduced in al-Zībaq edition, III, 16). Although not every Mālikite was necessarily of Maghribian/Andalusian origin, the majority of the Mālikites originated from these regions. In this context it is also remarkable that the Damascene hadīth scholar and historian 'Alam al-Dīn al-Qāsim b. Muhammad al-Birzālī (d. 739/1339), a Shāfíite scholar from Seville continued Abū Shāma's Dhayl.

147 In his case al-Madrasa al-Najībīya. On 'Abd Allāh b. Yahyāa al-Jazā’irīi (d. 682/1283), see al-Dhahabī, Ta'rīkh, years $681-90,103-4$. The sources give the nisba varyingly as

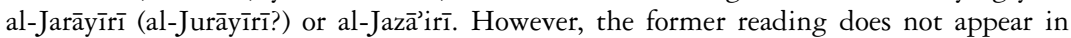
the relevant works on nisbas such as al-Sam'ān̄̄, Ansāb, or Ibn al-Athīr, Lubāb, where 'al-Jazā'irî', on the contrary, is mentioned as referring to the Maghrebian town.

148 In his case, the Dār al-Hadīth al-Nūrīya. On Ahmad b. Farah al-Ishbilī (d. 699/1300), see Seybold, C.F. in: EI2 'Ibn Farah' and for primary sources al-Dhahabī, Ta’rīkh, years 691-700, 383-4.

149 Who twice read the Muhaqqaq to Abū Shāma (notices in Abū Shāma, Muhaqqaq, 32) and once his Rawdatayn (notice reproduced in al-Zỉbaq edition, III, 16). On this scholar: al-Yūnīnī, Dhayl, IV, 307; al-Dhahabī, Ta'rīkh, years 681-90, 251; al-Ṣafadī, Wā̄ī, XXIX, 337-8; al-Nu'aymī, Dāris, I, 111.

150 Al-Dhahabī, Ta’rīkh, years 671-80, 73.

151 Al-Dhahabī, Ta’rìkh, years 671-80, 244.

152 Al-Dhahabī, Ta'rīkh, years 671-80, 348: 'laysa bi-al-muktbir'.

153 On 'Uthmān b. 'Abd al-Raḥmān Ibn al-Ṣalāḥ, see the references in al-Dhahab̄i, Ta’rīkh, years $641-50,184$.

154 On Aḥmad b. 'Abdallāh al-Tamīmī al-Ṣiqillī (d. 664/1266), see al-Dhahabī, Tảrīkh, years 661-70, 168-9.

155 Abū Shāma, Dhayl, 235.

156 Pouzet (1991), 194-5; Gilbert (1977), 203-4, argues that 'outsiders' had good chances to acquire posts in the town, as only 50 per cent were held by the grand families. Nevertheless, she does not differentiate between prestigious and minor posts, which would alter the rather harmonious picture of the 'international system of scholarship'.

157 Abū Shāma, Dhayl, 230.

158 Abū Shāma, Dhayl, 229-30. Nevertheless, he did not lead the main prayers in the Mosque, but only the prayers outside the town.

159 Abū Shāma, Dhayl, 233 and 236. 
160 Besides those mentioned, see Abū Shāma, Dhayl, 210 (al-'Afîf), 211 (Qaymāz al-Iqbālī), 217 (Ibn al-Najjār), 232 (Aḥmad al-'Irāqī), 232-3 (Ibrāhīm al-Qurashī), 234 ('Uthmān al-Sābiq), 234 (Jamāl al-Dīn al-Mișrīi), 235 ('Alī al-Qabāqīi), 237 (Tāj al-Dīn al-Iskandarīi).

161 Abū Shāma, Dhayl, 238 (Aḥmad and 'Alī), 235 (al-Ṣiqillī) and 240 (al-Saqațī). For al-Saqațī, see al-Yūnīnī, Dhayl, II, 364 and al-Dhahabī, Ta'rīkh, years 661-70, 188.

162 Abū Shāma, Dhayl, 189, where he called him 'șăbibunā'. Abū Shāma's proximity to the strong man of al-Jazīra, Muhī al-Dīn Muhammad b. Muhammad b. Sa'īd (d. 651/1253-4), mentioned by al-Ṣafadī, Wāeì, I, 172, cannot be found in any other source, including Abū Shāma's own writings.

163 Al-Yūn̄̄nī, Dhayl, I, 15-17; al-Dhahabī, Ta’rīkh, years 651-60, 163; al-Ṣafadī, Wāfì, V, 330; al-'Aynī, 'Iqd, I, 136, who all displayed a similar agreement on his insignificance. For his father, see Humphreys (1977), especially 285-92.

164 Abū Shāma, Dhayl, 184: 'șăbibunā'.

165 On Muhammad b. Ismā̄īil, see al-Dhahab̄̄, Ta’rīkh, years 641-50, 367-8.

166 'läkinnahu kāna kathīr al-ghadd min al-ulamà wa-al-akābir wa-al-sulaḅ̄' wa-al-ța'n 'alaybim wa-al-tanaqqus bi-him wa-dhakara masāwi' al-nās wa-thalaba a'rädabum wa-lam yakun bi-mathäba man lā yuqālu fìbi fa-qadaha al-nās fìhi wa-takallamū fì haqqibi wa-kāna 'inda nafsibi 'azīim an fa-saqața bi-dhälika min a'yun al-nās ma'a māa kāna 'alaybi min thalb al-'ulama' wa-al-a'yān'.

167 Altıkulaç (1975), 27ff. and Ahmad (1956) in his overall argument that Abū Shāma led a calm and easy life without encountering too many difficulties. Daiber (1985), 84, on the contrary, does not detect a specific anti-Hanbalite position in Abū Shāma's writings.

$168 \mathrm{Al}$-Wädìh al-jalī $f \bar{\imath}$ al-radd 'alā al-Hanbalī (The Elucidated and Clear Refutation of the Hanbalite). Only known manuscript in Chester Beatty Ar. 3307 (Arberry (1955-66)).

169 Abū Shāma, Dhayl, 207.

170 Al-Sakhāwī, I'lān, in: Rosenthal (1968), 340-7.

171 Al-Sakhāwī, I'lān, 108: 'wa-mimman umtubina bi-sabab ițlāq lisānibi bi-ghayr mustanad walā shubha al-imām Abū Shāma' (translation Rosenthal (1968), 353).

172 Ibn al-Furāt, Ta'rīkh, VII, 240-1: 'kāna yanbaghī lil-shaykh Shihāb al-Dīn [Abū Shāma] an

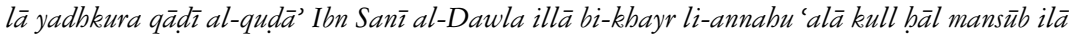
al-mubaddithīn wa-al-'ulama'’'.

173 Ibn al-Ṣuqā̄ì Tālīi, 99, no. 147.

174 Abū Shāma, Dhayl, p. 225, 1s. 2, 5 and 6.

175 Al-Dhahabīi, Ta’rīkh, years 641-50, 277-87; Humphreys (1977), 209-10.

176 Abū Shāma, Dhayl, 180.

177 Al-Dhahabī, Siyar, XXIII, 226: 'wa-mimman intașara la-bu [...] Abū Shāma fa-qāla kāna 'indabu min al-qiyām bi-wājib al-sharī'a mā lam ya'rifbu abad min al-mutasharri'īn żāhiran

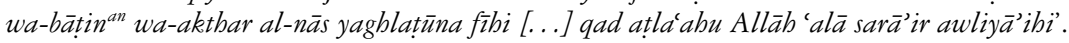
Taken up by Ibn Taghrībirdī, Nujūm, VI, 360 .

178 The question remains whether this citation from Abū Shāma originates from a source unknown to us, or whether it was inserted with a defamatory aim. The same problem appears with regard to Ibn Kathīr's statement that Abū Shāma 'defamed and criticized' the Damascene chief judge Ibn San̄̄ al-Dawla (d. 658/1260) (Ibn Kathīr, Bidāya, XIII, 237). In Abū Shāma's Dhayl no such tendency can be observed in the obituary notice on this chief judge (Abū Shāma, Dhayl, 206).

179 On Abū Shāma's stance towards this question, see Chapter 4.

180 Al-Ṣafadī, Wā̄ì XVIII, 113-16 and al-Asnawī, Tabaqāt, II, 118-19.

181 Ibn al-Șābūnī, Takmila, 211-13 (d. 680/1282); al-Yūnīnī, Dhayl, II, 367-8 (d. 726/1326); Ibn al-Ṣuqā̄ìi, Tālīi, 99, no. 147 (d. 726/1326). Al-Yūnīnī nevertheless cited without any comment the poem which Abū Shāma had written on the occasion of the first attack.

182 Al-Dhahabī, Qurrā', II, 673-4 (d. 748/1348); al-Kutubī, Fawāt, II, 271 (d. 764/1363); al-Ṣafadī, Wāfī, XVIII, 115 (d. 764/1362) and others, who referred it to the 'Jabalīya'. 
This explanation was lost in later sources owing to a spelling mistake, which made the ‘two men from the mountain' (rajulān jabalīyān), ‘two great men' (rajulān jalīlān), for example, al-Asnawī, Țabaqāt, II, 118-19 (d. 772/1370) and al-Sakhāwī, I'lān, 353 (d. 902/1497).

183 Ibn Kathīr, Bidāya, XIII, 264-5 (d. 774/1373); al-'Ayn̄̄, 'Iqd, II, 14 (d. 855/1451). Several authors did not give any details about the authors of the attack, for example, al-Subkī, Țabaqāt, VIII, 167 (d. 771/1369) or Ibn al-Jazarī, Qurrā', I, 366 (d. 833/1429).

184 Ibn Kathīr, Bidāya, XIII, 264-5; al-'Aynī, 'Iqd, II, 14, stated that 'he was accused of an affair' (wa-kāna qad uttuhima bi-amr) but claimed that Abū Shāma was innocent of it.

185 Nearly all medieval texts, which cited poems in the biography of Abū Shāma, included these lines.

186 Chamberlain (1994), 173.

187 On the competition between members of the elite in the town for posts in this period, see Chamberlain (1994), especially Chapter 3, 91-107.

188 Abū Shāma, Dhayl, 54-5: 'wa-jarā lī ukht hādhibī al-qạ̣̄yya wa-'aṣamañ̄ Allāh subbānabu bi-fadlibi.

189 Rosenthal (1946) and Rosenthal, F. in: EI2 'intihār'. Many contemporaries saw, for instance, the suicide of the seventh-/thirteenth-century mystic-philosopher Ibn Sab'in as a further proof that his teachings were heresies.

190 This point is also raised by Martel-Thoumian (2005), 407, in her study on suicide in late Mamluk society.

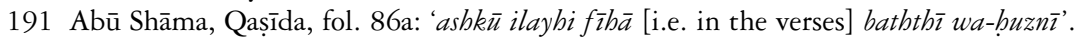

192 Abū Shāma, Qașīda, fols. 85b/86a: 'wa-țabīb bi-dawā' hādhibī al-'illa bașīr ashkū ilayhi

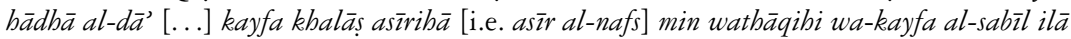
harbibi min jawrib $\vec{a}$.

193 'thumma dakhalat sanat tis' wa-tis'inn wa-hiya sanat mawlidī fa-fì salkh al-Mubarram laylat al-sabt mājat al-nujūm fì al-samā' sharq ${ }^{a n}$ wa-gharb ${ }^{a n}$ wa-tațāyarat ka-al-jarād al-muntashir

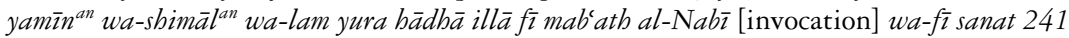
wa-kānat hādhibī al-sana a'zam'.

194 Al-Mas'ūdī, Murūj, V, 20-1, organized the events in the year 241/855-6 in such a way. However other earlier authors, such as al-Tabarī, had mentioned the storm but owing to an anti-Hanbalite stance had not established a link with his death (al-Tabarī, Ta'rīkh, XI, 172 and Kraemer's translation (1989), 137).

195 Even Hanbalite authors did not make this link explicit, see for example, Ibn al-Jawzī, Muntazam, VI, 485; similarly the Hanbalite turned Hanafite Sibṭ b. al-Jawzī, Mir'āt, VIII(2), 513.

196 Abū Shāma, Dhayl, 38.

197 Abū Shāma, Dhayl, 221.

198 Abū Shāma, Dhayl, 38: 'al-shaykh Abū Shāma nab̄̄ hādhā al-waqt'. This dream might be linked to strands of medieval Islamic thought, which considered dreams of the believer to be the continuation of the revelatory process (cf. Friedmann (1989), 83-4). The Persian mystic Rūzbehān Baqlī (d. 606/1209) recounted a similar vision where a voice announced his prophethood (Corbin (1966), 387-8). Here the prophetic philosophy of Shiism, which influenced Sufi concepts, might have played a role. The esoteric reading of the revelation and the resulting need for spiritual guidance led to Shiite notions of continuous prophethood (Corbin (1962), 69-78). However, it seems improbable that such notions might explain Abū Shāma's allusions in the various dreams and visions.

199 Abū Shāma, Dhayl, 39: 'wa-ammā bi-ni'mat rabbika fa-ḅaddith wa-qad qāla al-Nabì [invocation] lam yabqa min al-mubashsharāt illāa al-ru'yā al-ṣālị̣a yarāhā al-mu'min aw turā la-bu'. (translated by Fahd, T. in: EI2 (CD-Rom version) 'Ru'yā'.

200 Fahd (1966), 247-367. On the importance of dreams in medieval Muslim society, see Grunebaum (1966). 
201 Reynolds (2001), 90.

202 On dreams especially in the Damascene context contemporary to Abū Shāma, see Pouzet (1991), 372-7.

203 Abū Shāma, Dhayl, 38.

204 Kinberg (1985), 50.

205 On al-Nabulūsìs work, see Schimmel (1998), 233-40.

206 See for example the diary of an anonymous fifth-/eleventh-century scholar in Baghdad (Makdisi (1956-7)), which also shows the importance of dreams in a text that was not written for public circulation in this form (Reynolds (2001), 261). The surviving part, covering slightly more than one year, included twenty-three dreams, such as splendid honours he received from a shaykh for his great learning, a group of people divided about the question of prophethood consulting him and God informing him that his final abode will be heaven (Makdisi (1957), 13-14, 20-1 and 429).

207 Kinberg (1985).

208 See Kinberg (1993) on this issue.

209 Abū Shāma, Dhayl, 37-9, with continuation by students until 45. On it, see Lowry (1997) and Pouzet (1998).

210 Reynolds (2001), 6-7, refers to some 140 autobiographies written between the third/ninth and the thirteenth/nineteenth centuries. This number represents only a small fraction of the total body of Arabic autobiographical texts, which cannot be quantified yet.

211 Al-Ghamdi (1989), 188-9.

212 Lowry (1997), 322.

213 Reynolds (2001), 181.

214 I understand 'autodocumentary' writings as material where the author refers to himself. This includes autobiographical passages but also fragments, which would not be covered by the term autobiography.

215 Cahen (1940), 33.

216 Al-Ghamdi (1989); articles in special issue of Edebiyât: The Journal of Middle Eastern Literatures 7 (1997) on autobiography; Reynolds (2001).

217 Consequently, it was often TTāhā Husayn's (d. 1973) autobiographical account of his childhood and youth published in 1926-27 (English translation: Paxton, E.H. (1932) An Egyptian Childhood, the Autobiography of Taba Hussein, London), which included elements of European fictional writing, that was taken as the starting point of Arabic autobiography.

218 Reynolds (2001), 74.

219 Abū Shāma, Dhayl, 134: 'wa-tuwuffiyat wālidat̄̄ rahimabā Allāh wa-dafantuhā [...] wa-arjū an udfana 'indah $\vec{a}$.

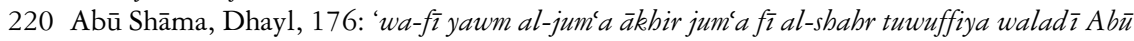
al-Haram Muhammad jama'an̄i Allāh wa-īyāhu fī al-janna wa-dafantubu 'inda ummibi bi-maqbarat Ibn Zuwayzān [...] wa-anā kuntu qābilabu wa-ghāsilabu'.

221 Abū Shāma, Dhayl, 196-8.

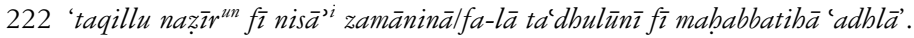

223 'māta jamā'a min aṣhābinā wa-ma'ārifinā wa-ghayribim fa-minhum sab'a kānū min sukkān

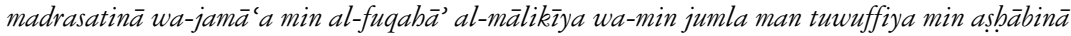
ithnān kānā min a'azzibim 'alaȳ̄ wa-aktharibim lī ijtimā'an abadubum Zayn al-Dīn [...]

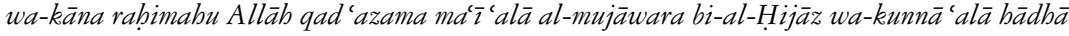
al-'azm fì hädhibī al-sana fa-ikhtaramathu al-manīya'.

224 Abū Shāma, Dhayl, 157: 'wa-lam yakun lī șāhib akhaṣs minhu kuntu ānasu bi-bi wa-bi-b̧adìthibi wa-fì adyaq mā akūnu min al-hamm ajtami'u bi-bi'.

225 As expressed by Rosenthal (1937), 32, who describes this section to be 'most meaningless' and 'emptiest exaggeration'. 


\section{INTELLECTUAL CONTEXTS}

1 'Science' here is used as the translation of 'ilm, pl. 'ulüm. It refers, in the sense of the German Wissenschaft, to an organized body of knowledge that constitutes a discipline with distinct goals, basic premises, methods and objects of inquiry.

2 Other classifications were based on the differentiation between theoretical and practical sciences (al-ulūm al-nażarìya and al'ulūm al-'amalīya) (e.g. al-Fārābī (d. 339/950), see introduction to the edition by 'Uthmān Amīn (1948) and Bakar (1998)), or between those disciplines of which the acquisition was obligatory for every believer (fard 'ayn) and those disciplines of which the acquisition was only obligatory for some individuals ( fard kifāya) (e.g. al-Ghazālī (d. 505/1111) (see Bakar (1998), 203-5).

3 Al-Azmeh (1986a), 157.

4 The discussion of the works of Abū Shāma and Ibn Wāṣil will - except where otherwise stated - only include those works which have come down to us. Works which are only known from references (either by the authors themselves or by other authors) will not be taken into consideration.

5 Abū Shāma, Dhayl, 42: 'malik al-fadl bal khalīfat 'ilm al-dīn'.

6 Abū Shāma, Dhayl, 39: 'wa-sannafa fì funūn al-'ulūm al-nāfi' 'a'.

7 Goldziher (1916/1970), 360. The term referred to a prayer by the Prophet: 'Oh God! I ask You for useful knowledge, plentiful blessing and acts accepted by you' (Ibn Hanbal, Musnad, VI, 345, no. 26594).

8 Abū Shāma, Ibrāz, 3: 'al-'ulūm al-nāfi' al-shar'ìya'.

9 Abū Shāma, Mu’ammal, 76: 'al-'ulūm al-d̦ärra'.

10 Abū Shāma, Bā'ith, 24, in a section on the differentiation between good and repugnant innovations: 'min al-bida' al-hasana al-tașānīf fî̀ jamī' al-'ulüm al-nāfía al-shar'ìya'.

11 For example Abū Shāma, Dhayl, 217, on al-Badr al-Marāghī (d. 660/1262) taken up in: al-Dhahabī, Ta’’rīkh, years 651-60, 411; Ibn Kathīr, Bidāya, XIII, 250; al-'Ayn̄̄, 'Iqd, I, 343. Also Abū Shāma, Dhayl, 202, on al-Fakhr b. al-Badī' (d. 657/1259) taken up in: al-Dhahabī, Ta’rīkh, years 651-60, 321; Ibn Kathīr, Bidāya, XIII, 231; al-'Ayn̄̄, 'Iqd, I, 227.

12 In contrast to the broad tolerance of the town's earlier ruler al-Malik al-Mu'azzam 'Īsā (d. 624/1227), al-Ashraf pursued a more limited approach to religious affairs. For example, after his accession to power he publicly stated that in the madrasas 'nobody of the jurisprudents should study anything except Quranic interpretation, tradition and jurisprudence' and threatened that whoever 'studies logic or the sciences of the Ancients will be exiled from the town'. (Ibn Kathīr, Bidāya, XIII, 157: 'nādā bi-al-madāris an lā yashtaghil ahad "un min al-fuqabä' bi-shay' min al-'ulüm siwā al-tafsīr wa-al-badīth wa-al-fiqh wa-man yashtaghilu bi-al-mantiq wa-'ulüm al-awa'̀il nufiya min al-balad').

13 'Al-falsafa uss al-safah wa-al-inhilāl wa-māddat al-hayra wa-al-dalāl wa-maqāl al-zaygh wa-al-zandaqa wa-man tafalsafa 'amiyat bașīratubu min mahāsin al-sharī'a al-mu'ayyada bi-al-barāhīn wa-man talabbasa bi-hā qāranabu al-kbidblān wa-al-birmān wa-istaḅwadha 'alaybi al-shaytān wa-azlama qalbubu 'an nubüwat Mubammad [invocation] [...] isti'māl al-iștilāhāt al-mantiqūya fì mabāhith al-ahkām al-sharìya min al-munkarāt al-mustabsha'a wa-al-raqā'āt al-mustahdatha wa-laysa bi-al-abkām al-shar'īya wa-lillāh al-hamd iftiqārun ilā al-manțiq așlan [...] fa-al-wäjib 'alā al-sulțān [invocation] an yadfá' 'a 'an al-Muslimīn

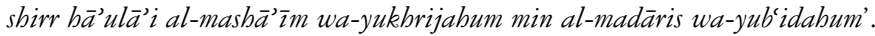

14 On 'Abd al-Karīm b. 'Abd al-Ṣamad Ibn al-Harastānī (d. 662/1264), see Abū Shāma, Dhayl, 229-30; al-Yūnīnī, Dhayl, II, 295-6; al-Dhahabī, Ta’rīkh, years 661-70, 104-5; al-Ṣafadī, Wāầ, XIX, 78-9; al-Asnawī, Țabaqāt, I, 446-7.

15 On Yahyā b. Sharaf al-Nawawī or al-Nawāwī (d. 676/1277), see Heffening, W. in: EI2 'al-Nawaw $\overline{1}$ ' and al-Dhahabī, Ta'rīkh, years 671-80, 246-56.

16 However, in his obituary notice for al-Āmidī (Dhayl, 161), Abū Shāma did not mention that he studied with him, in contrast to the obituary notices on his teachers such as 
Ibn 'Asākir (Dhayl, 137), Ibn al-Ṣalāḥ (Dhayl, 175-6) and al-Sakhāwī (Dhayl, 177). On al-Āmidī, see al-Dhahabī, Ta'rīkh, years 631-40, 74-6.

17 On this differentiation, see Pouzet (1991), 172-82.

18 Abū Shāma, Ibrāz, 3.

19 Hājj̄i Khalīfa, Kashf, 646-9.

20 Pouzet (1991), 176-8.

21 Abū Shāma, Dhayl, 7: 'tawarru' mimmā kāna yalzamūna bi-hi al-khuṭabā' min dhikribim 'alā al-manābir bi-awșāf lam yarahā sā'igha shar 'an'. On the term wașf, see Arazi, A. in: EI2 'wașf'.

22 Şeşen et al. (1995), 16, no. 4.

23 Habshī (1994), 144, no. 322 and 247, no. 593.

24 Ảbū Shāma, Ibrāz, BL, Add 27507, fol. 147a.

25 Al-Dhahabī, Ta’rīkh, years 661-70, 195: 'nafī̄'; al-Yāfi'ī, Mir'āt, IV, 164: 'ghāyat al-jūda'; Ibn al-Jazarī, Qurrā', I, 365-6: 'mashbūr'.

26 For example Chester Beatty Ar. 3502 (fols. 1-65), Ar. 3653 (fol. 21-56a) and Ar. 4693 (fols. 70-145) (Arberry (1955-66)).

27 Al-Subkī, Tabaqāt, VIII, 165: 'among his excellent works' (wa-min mahāsinibi Kitāb al-Basmala) and al-Asnaw̄̄, Tabaqāt, II, 119: 'his famous work' (wa-taṣñ̂fuhu al-mashbūr fì āyāt al-Basmala).

28 Chester Beatty Ar. 3502 (fols. 67-91) (dated 797/1394); Chester Beatty Ar. 3307 (fols. 387-408) (dated 701/1301) (Arberry (1955-66)); Vatican 1384 (copied 788/1386) (Della Vida (1935), 213-4); Damascus, al-Zāhirīya, Qur’ān, 2352 (copied 739/1338) (al-Khaymī (1983-4), II, 244).

29 Al-Dhahabī, Huffāz, IV, 243-4.

30 Al-Subkī, Ṭabaqāt, VIII, 165-7, and Hājjī Khalīfa, Kashf, 1982.

31 These two works have only survived in one collective manuscript, which includes also al-Yūnīnī's work, see Chester Beatty Ar. 3307 (Arberry (1955-66)).

32 Pouzet (1991), 359.

33 Compare Hājjīi Khalīfa, Kashf, 1331-6.

34 Vajda (1956), 40-1: Abū Shāma, Ibrāz, Paris BN, arabe 3141, fol. 177. See Chapter 3 on this scholar and his nisba.

35 Hājjī Khalīfa, Kashf, 1774, alone enumerated six explanations written in the seventh/thirteenth century.

36 Pouzet (1991), 35-9.

37 Only manuscript in Chester Beatty Ar. 3307 (Arberry (1955-66)). Edition by Ahmad al-Kuwaytī (1988).

38 In the 1984 edition used here, 30 out of a total of some 1300 pages are devoted to this subject (al-Āmidī, Iḥkām, I, 223-52).

39 Manuscripts in Rāmpūr (Brockelmann (1949), 386-7). The edition used here (Ahmad, Kuwait 1983?) does not state which manuscript(s) was/were used.

40 Only copy in the collective manuscript Chester Beatty Ar. 3502 (Arberry 1955-66). The edition used here ('U.A. 'Anbar, Cairo 1978) mentions a manuscript at the Azhar without stating which manuscript(s) was/were used for the edition.

41 Bakar (1998), $184 \mathrm{ff}$.

42 Pouzet (1991), 199-205.

43 Such as al-Khusrūshāhī and Muhammad b. 'Abd al-Raḥ̄m al-Hindī (d. 715/1315).

44 Abū Shāma, Daw', 29: 'al-adilla al-sam'īya mustafāda min al-Qur'ān wa-min al-sunna al-thābita'.

45 Arberry (1955-66), II, 27. Both works are contained in the collective manuscript Chester Beatty Ar. 3307 (Arberry (1955-66)).

46 Abū Shāma, Dhayl, 39.

47 Chester Beatty Ar. 3307, which also contains eight works such as his Concise Guide, Light of the Nocturnal Moon and What Can Be Ascertained, as well as his introduction (Arberry (1955-66)). 
48 Only copy in the collective manuscript Chester Beatty Ar. 3307 (Arberry (1955-66)). Siwa $\bar{a}$, the act of cleansing the teeth (the term refers also to the toothpick/toothbrush itself), came generally to be regarded as a recommended practice, owing to the Prophet Muhammad's example.

49 Al-Kutubī, 'Uyūn, XX, 353: 'wa-la-bu shi'r lā ba's bi-bi'.

50 Al-Āmidī, Iḥkām, IV, 169 (translated in Weiss (1992), 683).

51 The most often-cited representative of this tendency was Schacht (1964), 71, where he coined the phrase of the 'closing of the door of ijtihād'.

52 Watt (1974) and Weiss (1978), express early scepticism about Schacht's view. The decisive revision has been undertaken by W.B. Hallaq, most importantly Hallaq (1984) and (1986). This debate is summarized in the descriptive article by Ali-Karamali/ Dunne (1994).

53 Weiss (1992), 723-5.

54 Calder (1996) and Jackson (1996), 73-96. Gerber (1999), sets out to challenge their arguments by discussing the continued application of $i j t i b \bar{a} d$ during the Ottoman times. However, his discussion refers mainly to examples which support the view that ijtihäd was only applied to the Two Sources in a very limited number of cases.

55 Poya (1998), 229-30.

56 Calder (1996), 155.

57 Al-Dhahabī, Huffāz, IV, 243; al-Subkī, Ṭabaqāt, VIII, 165; Ibn Kathīr, Bidāya, XIII, 264.

58 On Muhammad b. 'Alī Ibn Daqīq al-'̄̄d (d. 702/1302), see al-Dhahabī, Huffāze, IV, 262-3; al-Șafadī, Wāè̄, IV, 193-209; al-Subkī, Ṭabaqāt, IX, 207-49; al-Asnawī, Țabaqāt, II, 227-33.

59 Ảbū Shāma, Mu’ammal, 45: 'faṣl fì wujūb al-rujū' ilā al-kitāb wa-al-sunna'.

60 Abū Shāma, Mu’ammal, 45, citing the ḩad̄̄th scholar 'Āmir b. Sharāhịl al-Sha'bī

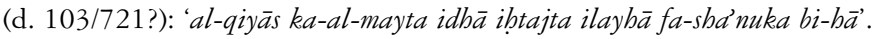

61 Abū Shāma, Mu’ammal, 47: 'nahā al-Shāfic̀ 'an taqlìdihi wa-taqlīd ghayribi', similarly 57-61.

62 Abū Shāma, Mu’ammal, 39: 'lā yajūzu li-ahad an yaḅtajja bi-qawl al-mujtabid li-anna al-mujtabid yukbti'u wa-yușību'.

63 Abū Shāma, Mu’ammal, 42.

64 Abū Shāma, Mu’ammal, 41: 'șārat aqwāl a'immatibim 'indahum bi-manzalat al-aṣlayn'.

65 Abū Shāma, Mu’ammal, 54-5.

66 Abū Shāma, Mu’ammal, 27.

67 Abū Shāma, Mu’ammal, 47-8. Hallaq (2001), 123, refers to this passage but identifies Abū Shāma wrongly as 'Ibn Abī Shāma'.

68 Weiss (1992), 171-2.

69 Abū Shāma, Muhaqqaq, 66-7. His previous discussion dealt either with acts irrelevant to the believers (routine acts (45-51) and acts specific to the Prophet (51-6)) or those beyond discussion (e.g. acts known to be obligatory for the Prophet and the believers simultaneously (salāt, jihād etc.) (45)).

70 On these prayers, see Kister (1971), Pouzet (1991), 343-5 and Fierro (1992), 226.

71 On the outstanding status of Rajab, see Kister (1971).

72 Al-Subkī, Țabaqāt, VIII, 251-5.

73 Abū Shāma, Bā'ith, 45-6.

74 Abū Shāma, Bā'ith, 25: 'tawā' if min al-muntamīn ilā al-faqr alladbī baqūqatubu al-iftiqār min al-ìmān'. He specifically named in this context a spring, a pillar, and a tree at the Damascene gates of Tūmā, al-Șaghīr and al-Nașr respectively.

75 Although Ibn Taymìya succeeded in banning the prayers between 702/1302-3 and 706/1306-7 they were finally reintroduced under popular pressure (Pouzet (1991), 344).

76 Abū Shāma, Dhayl, Berlin Spr. 53, fol. oa.

77 On the genre of treatises against innovations, see Fierro (1992), Berkey (1995) and Lohlker (1999). 
78 Berkey (1995), 41.

79 Fierro (1992), 210.

80 I agree with Jackson (1996), 77-8, that the crucial question is one of hegemony. It is beyond doubt that taqli $d$ was the dominant mood during this and the following periods. However, the continued existence of $i j t i h \bar{a} d$ in its classical sense should not be excluded in absolutist terms.

81 Jackson (1996), 79-83; Calder (1996), 151-2; Fadel (1996); Hallaq (2001), 86-120.

82 Hallaq (2001), p. IX.

83 See for example the analysis of Ibn Taymīya's argumentation based on a mixture of taqlìd and ijtihäd in Jokisch (1996), 205-51.

84 Makdisi (1985), 81-2.

85 Hallaq (2001), 87.

86 Abū Shāma, Mu’ammal, 68: 'wa-lākinna a'māhu al-taqlīd așammahu 'an simā' al-ilm al-mufìd'.

87 Abū Shāma, Mu’ammal, 42: 'fa-'adima al-mujtabidūn wa-ghalaba al-muqallidūn'.

88 Abū Shāma, Mu’ammal, 36: 'wa-qad su'ila ba'd al-'ärifīn 'an ma'nā al-madhbab fa-ajāba anna ma'nāhu dīn mubaddal'.

89 Abū Shāma, Mu’ammal, 42.

90 Abū Shāma, Murshid, 173-9.

91 Ibn al-Jazarī, Munjid, 199, citing Muhammad b. Muhammad al-Jamālī (d. 784/1382): 'yanbaghì an yu'dama hādhā al-kitāb min al-wujūd wa-lā yazhara al-batta wa-annabu țán fì al-dīn'.

92 Ibn al-Jazarī, Munjid, 209.

93 Altıkulaç (1975), 38 (Introduction). The relevant manuscripts are: Ayasofya 59 and Şehit Ali 2751.

94 It is indeed in the field of speculative theology that the 'traditionalists versus rationalists' dichotomy retains an analytical usefulness. On this issue, see the discussion by Abrahamov (1998). This analytical usefulness is much more doubtful with regard to the issue of jurisprudence.

95 On the term bukm used by Abū Shāma here in reference to Quran 21:78, see Paret (1977), 73.

96 Abū Shāma, Mu’ammal, 43: 'qawm [... ș̣ārat 'aqìdatubum fī al-ishtighāl bi-'ulūm al-așlayn yarawna anna al-ülā minhu al-iqtișār 'alā nukat khilāfīya wada' ūhā wa-ashkāl manțiqūya allafüh $\bar{a}$.

97 On the importance of authority in the legal field in general, and especially the link between authority and $i j t i \bar{a} \bar{d}$, see Hallaq (2001).

98 Abū Shāma, Mu'ammal, 27: 'fa-inna al-'ilm qad durisat a'lāmubu wa-qad qalla fī hādhā

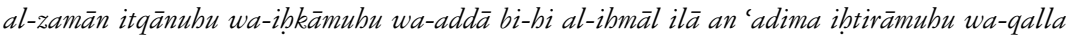
ijlālubu wa-i'zāmubu'.

99 'fa-kayfa law ra'ā al-șabāba mā qad uhditha min hādhibī al-șalawāt al-mubtada' a fī al-awqāt

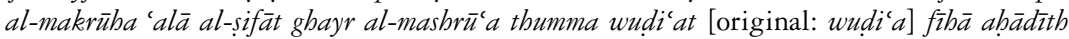

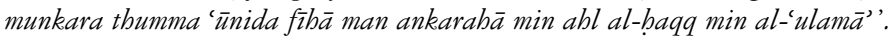

100 Abū Shāma, Mu’ammal, 34, citing Wahb b. Munabbih al-Yamanī (d. 114/732): 'fa-tarahū 'ilmahum 'alā al-mulūk wa-abl al-dunyā fa-ibtadamūhum wa-ibtaqarūbum'.

101 Abū Shāma, Dhayl, p. 224, 1. 16: 'bubb hādhibī al-dunyā așamma wa-a'mā'.

102 'fa-ikbtartu an atanabhālwa-astaqilla bi-amrī fa-lastu amshī ilā man/yurā khațīin ${ }^{a n}$ li-qadrī

li-ajli al-dunyā fa-mashìlilaybi bi-al-ilm yazrī

läkinna ilā 'álim ${ }^{i n}$ aw/shaykh in nabīh al-dhikr

fì al-dīn ${ }^{i}$ yaqșidu lil-'ilmi/wa-al-tuqā lā al-fakbr'.

103 For example, Abū Shāma, Bācith, 56.

104 Abū Shāma, Mu'ammal, 30: 'inna Allāh yuqayyiḍu lil-nās fī ra's kull mi'at sana man yúallimubum al-sunan wa-yunfī 'an rasūl Allāh [invocation] al-kidbb'. Similar on p. 42.

105 Abū Shāma, Mu’ammal, 42-3.

106 Landau-Tasseron (1989), 84. On the issue of tajdìd, see also Friedmann (1989), 94-101. 
107 Calmard, J. in: EI2 'mudjtahid'.

108 Al-Suyūti, Tahadduth, 219-20.

109 Landau-Tasseron (1989), 86.

110 Sartain (1975), 72.

111 "nawwara Allāh" al-wajh' wa-al-qalba minhulinna fīhi bidāyat" al-murtāb

buwa shaykhin ma'nan fa-'ajalabu al-shaybu/waqāa an la-bu 'alā al-atrāab'. (Translated with slight changes in Reynolds (2001), 184).

112 Abū Shāma, Dhayl, 39.

113 See Chapter 3.

114 On his autobiography, see Reynolds (2001), 3-5, 87-8 and 202-7, as well as Sartain (1975), 137-41.

115 Abū Shāma, Ibrāz, 8.

116 Abū Shāma, Dhayl, 175, on Husayn b. Ab̄̄ al-'Izz al-Hamadhān̄̄ (d. 643/1245): 'fa-kbāda bahr an 'ajaza 'an sibābatibi'.

117 Laoust (1955), 44-5.

118 It is significant that Ibn Kathīr's historical perception as well as his position on figh, made his chronicle al-Bidāya wa-al-nibāya the most popular historical work in Wahhābite circles in the early twentieth century (Steinberg (2000), 99-100).

119 Abū Shāma, Mu’ammal, 42-3.

120 Abū Shāma, Mu’ammal, 44, citing 'Āmir al-Sha'bī (d. 103/721): 'idhā jāàaka al-khabar 'an aṣhāb Mubammad fa-da'bu 'alā ra'sika wa-idhā ja'aka 'an al-tābi'in fa-idrib bi-bi aqfiyatabum'.

121 On the question of continuity between post-formative mujtabids such as Abū Shāma and the eighteenth- and nineteenth-century revivalists see Hirschler (2005).

122 Al-Sanūsīi, Īqāz, 73-4.

123 With the exception of Ibn Taymīya and Muhammad b. al-'Arabī (d. 543/1148), a Mālikite from the western lands who stands out in this second part. A third part of the list refers to six individuals who claimed the rank of mujtahid, among them Ibn al-Ṣalāh and al-Suyūṭī.

124 Al-Shawkānī, Irshād, 254.

125 Shāh Walī Allāh, Inșāf, 32 and 'Iqd, 358.

126 Al-Ṣafadī, A'yān, IV, 1660: 'bara'a fì al-'ulüm al-shar'ìya wa-țala'a ka-al-shams fì al-ulūm al-'aqlīya'.

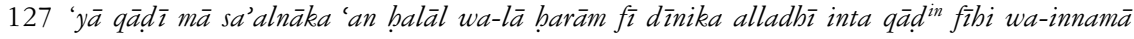
sa'alnāka' 'an ashyā' lā ya'rifubā illā al-falāsifa al-aqdamūn fa-ajabta' 'anbā wa-laysa ma'aka kutub wa-lā mā yasta'ìnu bi-bi'.

128 Abū al-Fidā', Mukhtașar, IV, 38.

129 The focus on rational sciences in al-Karak was limited to the person of al-Malik al-Nāșir who took a strong personal interest in rational sciences and offered patronage to scholars pursuing them. This became characteristic for him, but did not lead to a lasting tradition in al-Karak. For example, his successor al-Malik al-Mughīth 'Umar (d. 662/1264) displayed no comparable interest regarding the patronage of scholars.

130 In contrast to al-Karak, this patronage was not limited to one specific ruler but remained a practice over several generations, stretching from the rule of al-Malik al-Manșūr Muhammad (d. 617/1221) to the rule of Abū al-Fidā' in the first decades of the eighth/fourteenth century.

131 Al-Subkī, TTabaqāt, VIII, 210: 'baladuka saghīrn' 'alā 'ilm $\bar{\imath}$ '.

132 Ibn Wāṣil, Mufarrij, V, 35-9, on 'Abd al-Hamīd b. 'Alī al-Khusrūshāhī (d. 652/1254).

133 Al-Dhahabī, Ta’rīkh, years 681-90, 348-9, on Muhammad b. Maḥmūd al-Iṣfahānī (d. 688/1289).

134 Ibn Wāṣil, Mufarrij, V, 35: 'al-'ulūm al-nazarīya'.

135 Abū Shāma, Dhayl, 124; al-Dhahabī, Ta’rīkh, years 611-20, 379. 
136 Ibn Abī Ușaybī'a, 'Uyūn, III, 385.

137 Ibn Khallikān, Wafayāt, V, 315-16; al-Dhahabī, Ta’rīkh, years 641-50, 429-30; al-Șafadī, Wāfí, XXIV, 304 on 'Alam al-Dīn Qayșar b. Abī al-Qāsim (d. 649/1251).

138 Al-Ṣafadī, Wāfī, III, 85, on 'Alī b. 'Umar al-Qazwīnī (d. 675/1276). For further sources, see al-Dhahabī, Ta'rīkh, years 671-80, 207.

139 Abū al-Fidā', Mukhtașar, IV, 38-9. This ruler continued in the eighth/fourteenth century the tradition of his predecessors. He himself was learnt in the religious sciences and also in fields such as philosophy, logic, astronomy and medicine (al-Kutubī, Fawāt, I, 183-8 and al-Asnawī, Tabaqāat, I, 455-6).

140 Ibn Qāḍ̄ Shuhba, Ṭabaqāt, II, 125: 'bālagha fī 'ulūm al-awà'il hattā tafarrada bi-ri' āsat dhālika fì zamānibi'.

141 Reinecke Rare Book and Manuscript Library, Yale University, no. 1407 (copied around 680/1281) (Nemoy (1956)); Alger, no. 1387 (copied in 738/1337-8) (Fagnan (1893)); Escurial 647 (copied in 746/1345) and Escurial 615 (not dated) (Derenbourg (1884-1928), I, 425-6 and 455).

142 The five commentaries, besides Ibn Wāșil’s work, listed by Hājjī Khalīfa, Kashf, 602 and Brockelmann (1949), 463, were all written in the eighth/fourteenth century.

143 Only manuscript in Reinecke Rare Book and Manuscript Library, Yale University, no. 1406 with the title Nukbbat al-fikar fì tathqîf al-nazar; copied in 680/1281 by a Yūsuf b. Ghanāim al-Sāmirī in Hama from an autograph draft manuscript (fol. 133a/b).

144 Ibn Wāṣil, Nukhbat, fol. 134a: 'nazara fì hādhà al-kitāb [...] al-bājj Hasan b. al-bājj

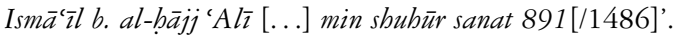

145 Rescher (1964), 199.

146 Ibn Taymīya, Jahd (translation W.B. Hallaq), 59.

147 See Rescher (1964), 64-7, on the development of the Western and Eastern schools.

148 Al-Khūnajīi, Ibn al-Nafīs and al-Khusrūshāhī.

149 Ibn Wāṣil's student Muhammad b. Ibrāhīm Ibn al-Akfānī (d. 749/1348) cited it as Lubāb al-arba'ìn (Gist of the Forty), see Ibn al-Akfānī, Irshād, 43-4.

150 This genre encompassed mainly hadith booklets, which were used as first manuals for students starting a given subject (Pouzet (1991), 199).

151 Al-Rāzì, Arba'īn, 122ff., 133ff., 154-5 and 189.

152 Three manuscripts of this work have been preserved (Brockelmann (1949), 393-4). BL, Add 7339 was copied in early twelfth/late seventeenth century in Hama by a certain Muhammad, imam of the Shaykh 'Ulwān Mosque.

153 Ibn Wāșil, Aghānī, BL, Add 7339, fol. 106b: The sentence 'The devil is more virtuous than your forefather Adam' (Iblīs afdal min abīkum Ādam) was crossed out and commented in the margins with 'I ask God for forgiveness for what my pen brought about' (astaghfiru Allāh mimmā jarā bi-bi qalamī).

154 Ḥājjī Khalīfa, Kashf, 1134. Ibn Wāṣil’s commentary has survived in two manuscripts: Paris BN, arabe 4451 (de Slane (1883-95), 710) and Princeton, Garrett Collection, no. 503 (Hitti et al. (1938), 168-9). The first was copied in 732/1332, the second was probably written within the lifetime of the author.

155 Medicine: Summary of al-Mufrada by his teacher Ibn Bayțār; Astronomy: Nukbbat al-amlāk fì hay'at al-aflāk and a summary.

156 Leder et al. (1996), 54 and 66: In Damascus in the early 620s/mid-1220s with Muhammad b. Yūsuf b. Muhammad al-Birzālī (d. 636/1239).

157 Ibn Wāṣil, Mufarrij, IV, 311: In Aleppo in the late 620s/early 1230s with Muhammad b. Abī Bakr Ibn al-Khabbāz (d. 631/1234).

158 Ibn Wāṣil, Mufarrij, IV, 78: 'kāna imāman 'azīman mutaqaddiman fì' 'ilmay al-kalām wa-usūul al-fiqh wa-'ilm al-mantiq wa-sā'ir al-'ulūm al-bikmīya'.

159 Ibn Wāṣil, Mufarrij, I, 210-11.

160 Ibn Wāṣil, Mufarrij, V, 251: 'wa-kānat baynañ̄ wa-baynabu mawaddat ${ }^{u n}$ '. 
161 Under Hasan III (d. 618/1221) the Ismailis in Alamūt adopted Sunnism. However, his son and successor Muhammad III (d. 653/1255) reversed this rapprochement in practice, though not officially. Irrespective of these developments, throughout the first half of the seventh/thirteenth century the Ismailis in Syria remained a threat to individuals in major towns such as Damascus (see Pouzet (1991), 250-2, on attacks in Damascus).

162 Cited also with some changes in Ibn Wāṣil's biography in al-Ṣafadī, A'yān, IV, 1661; see also 'Īsā (1942).

163 Calabī al-Rūmī, Sharh, 63: 'amr an yashhadu șarīh al-'aql bi-fasādibi'.

\section{TEXTUAL AGENCY I: TITLES, FINAL SECTIONS AND HISTORICIZATION}

1 Rosenthal (1968), 83.

2 Abū Shāma's work has been praised as the work with the greatest number of original documents of its time (Ahmad (1962), 84) and being 'of great interest' to the period of Nūr al-Dīn (Elisséeff (1967), 53). However, the fact that Abū Shāma did not narrate his own period limited his importance despite 'several reliable accounts, some of which can rarely be found elsewhere' (Ahmad (1962), 94).

Ibn Wāșil's work has been described as 'the most important source for the late Ayyubids' (Halm (1991), 689) and praised for its 'unique importance' to the history of the seventh/ thirteenth century (Gottschalk (1958), 7). Furthermore, it gives 'an outstanding clear and coherent survey' with 'fairmindedness and evenhandedness' although Ibn Wāṣil 'tends to oversimplify complex events' (Humphreys (1977), 395-6).

3 The only exception is Daiber's (1985) short article, where he discusses the relationship between theology and history in the Rawdatayn.

4 For the evaluation of Ibn Wāsil's work as a panegyric, see Chapter 3. The broadest and most detailed overview of the issue of dynastic biases in this period's texts is still Gibb (1950). For Abū Shāma, see for example Ehrenkreutz (1972), 3, where all chroniclers during this period are criticized for their 'tendency to hero-worship and to idealize their heroes'. Holt (1986), 39, detects a more complex picture when he comments briefly on the work's purpose as being 'essentially didactic - a warning and a summons to the Muslim rulers of his time'.

5 The study closest to such an approach for 'post-classical' Arabic historical writing is Weintritt (1992).

6 Discussed for the case of rhymed prose in Richter-Bernburg (1998), 137-89.

7 For a brief discussion of White's concept of narrativity by a historian of the Middle East, see Waldmann (1981), where she argues against the exclusion of 'mere' chronicles and annals from the analysis.

8 White (1973), 7.

9 Goertz (2001), 28. Shopkov's (1997) study of eleventh- and twelfth-century historical writing in Normandy suffers from a formalistic application of White's categories without reflecting on the period's specificity in this regard.

10 Freimark (1967), 3.

11 The employment and function of 'circularity' will be discussed in the following chapter.

12 The Sultanic Anecdotes and the Yusufit Merits (hinting at the often established link between the Quranic Joseph (Arabic: Yūsuf) and Șalāḥ ad-Dīn, whose ism ('first name') was Yūsuf.

13 Treasures of Those Professing the Oneness of God: the Biography of S Salāh al-Dinn.

14 The Qussian Inspiration on the Conquest of Jerusalem referring to Quss b. Sā'ida (purportedly d. around $600 \mathrm{CE}$ ) who was considered the classical example of eloquence.

15 Ambros (1990), 38-41 (length) and 45-6 (rhyme scheme).

16 Ambros (1990), 13, whose technical vocabulary (thematic phrase, guiding phrase) I use in the following. 
17 With regard to the two texts studied here Hillenbrand (1999), 193, is the exception. She states briefly: 'The word rawda [garden], [...] also has paradisal connotations, and these may be deliberately alluded to here [in the title of Abū Shāma's work]'. In general, such references are limited to those works, where the medieval authors discussed explicitly his choice of title, for example, Richter-Bernburg (1998), 194-200, on 'Imād al-Dīn's al-Barq.

18 See the biographical entries on Ibn Wāșil and Abū Shāma, enumerated in Chapter 3.

19 For example, al-Yūnīnī, Dhayl, II, 368, referring merely to 'al-Rawdatayn'.

20 Abū Shāma, 'Uyūn, I, 179: 'fa-hādhā mukhtașar Kitāb al-rawdatayn alladh̄̄ kuntu jama'tubu fì akbbār al-dawlatayn [...]'.

21 Ambros (1990), 20-30. The most commonly used terms were durr (pearls) and tubfa (rarity, gem).

22 Besides Ambros (1990), 22, this is also visible in Hājjjī Khalīfa's Kashf al-zunūnn. Here more than 130 titles starting with rawd or rawda, over 35 starting with riya d, and an even higher number containing the terms within their titles are enumerated.

23 Some titles used the verbal noun, such as the military manual entitled: The Dissipation of Anxieties Regarding the Preparation of Warfare (Scanlon, G.T. (ed., tr.) A Muslim Manual of War, Being Tafrīj al-kurūb fì tadbìr al-burūb by 'Umar b. Ibrāhīm al-Awsī al-Ansarī, Cairo 1961).

24 Ambros (1990), 13-14. Carmona (2000) adds in his brief study of Arabic book titles a third consideration: to provide the book with a short, easy to learn title.

25 The title's first term ' $k i t a \bar{b}$ ' was obviously commonplace in titles of this period, and cannot serve for further analysis.

26 Al-Bundārī, Sanā, 52.

27 For details of this work, see the following passage on Ibn Wāṣil.

28 Manādih al-mamādiḥ wa-rawdat al-ma'àthir wa-al-mafäkhir fì khașā'is al-Malik al-Nāsirir by the Andalusian poem and physician 'Abd al-Mun'im b. 'Umar al-Andalusī al-Jilyānī (d. 602/1205). After having settled in Damascus he finished this poem in 568/1172-3. For more on him, see al-Dhahabī, Ta'rīkh, years 601-10, 120-1 (year 603) and Ibn Abī Ușaybī‘a, 'Uyūn, III, 259-65.

29 For example Abū Shāma, Rawḍatayn, II, 80-1.

30 Abū Shāma, Rawḍatayn, I, 50: 'wa-dawlatubu ma'mūla ma'mūna wa-rawdatubu mașūba mașūna'. Not in Ibn Wāṣil, Mufarrij.

31 Abū Shāma, Rawḍatayn, III, 345: 'wa-tanazzahū min zabr karāmātibi fí al-rawd al-añ̄q'. Not in Ibn Wāṣil, Mufarrij.

32 Wescoat (1986), 13. This vision also led to a further meaning of 'garden', symbolizing the lands to be protected under one's rule. For example, 'Imād al-Dīn Zankī, Nūr al-Dīn's father, was cited with the words: 'The lands are like a garden surrounded by a hedge.' (al-bilād ka-bustān 'alaybi siyāj) (Abū Shāma, Rawḍatayn, I, 159; Ibn Wāṣil, Mufarrij, I, 103). This concrete meaning also occurred regularly in writings on political theory. Ibn Khaldūn cited a section ascribed by Muslim authors to Aristotle as: 'The world is a garden [bustān] the fence of which is the dynasty [dawla]. The dynasty is an authority [sultāan] through which life is given to proper behaviour [sunna]. Proper behaviour is [...].' (Ibn Khaldūn, Muqaddima (translation Rosenthal (1967)), I, 81-2. See note 29 there for further works in which this circle appeared. The Arabic terms are cited from the 1958 edition of the same work.)

33 See for example Marçais, G. in: EI2 ‘Bustān’, Wescoat (1986), Barrucand (1988) and Rubiera y Mata (1995). The problem of the absence of detailed studies is particularly strong for the Arabic Middle East, which unlike Safavid Persia, Mughal India, Timurid Central Asia or Arabic Spain, left few traces for allowing an in-depth study. Petruccioli (1995) is a good starting point for further reading on this subject. The general term for paradise is janna, with some secondary terms, such as rawda, employed occasionally. Abū Shāma's choice of this secondary term might have been aimed at avoiding identifying the earthly garden and the 
celestial paradise directly while implying this connotation. At the same time, the pair rāwda and dawla was an obvious choice for his work observing the demands of rhyme.

34 For example, the Prophetic hadìth 'Between my grave or between my house and my pulpit is a garden of the gardens of paradise.' (bayna qabrī aw baytī wa-minbarì rawda min riyāe aljanna) (Quoted in Ibn Manzūr, Lisān, entry $r-w-d$ ). On the concept of linking graves metaphorically to garden see Schöller (2004), 48-54. Another, more mundane, example would be Ibn Jubayr's description of Damascus. After having referred to the gardens [riya $d]$ in its surrounding he acclaimed: 'If paradise is on earth then Damascus without a doubt is in it. If it is in the sky, then it vies with it and shares its glory.' (Ibn Jubayr, Rihla, 261: 'in kānat al-janna fì al-ard fa-Dimashq là shakka fīhà wa-in kānat fí al-sam $\bar{a}$ ' fa-biya bi-haythu tusāmitubā wa-tuhādhīhā'. Translated in Broadhurst (1952), 272).

35 Based on Quran 55:46: 'wa-li-man khäfa maqām rabbibi jannatān' and following verses.

36 Quran 39:73 referred to the gates of paradise implying its enclosure.

37 Abū Shāma, Rawḍatayn, IV, 356: 'wa-al-fuqarā' fī riyād șadaqātibi rāti' $\bar{u} n$ '. Not in Ibn Wāṣil, Mufarrij.

38 Abū Shāma, Rawḍatayn, IV, 371, including elegy on Șalāh al-Dīn: 'fī nuṣrat al-islām yasharu da' im an/li-yatūla fî̀ rawd al-jinān subātubu'. Not in Ibn Wāṣil, Mufarrij.

39 Abū Shāma, Rawḍatayn, IV, 359. Not in Ibn Wāṣil, Mufarrij.

40 Abū Tammām, poet, d. 231/846.

41 Abū Shāma, Rawḍatayn, I, 31: 'wa-sammaytuhu "Kitāb al-rawdatayn fī akbbār al-dawlatayn" wa-lillāh darrubu Habīb b. Aws haythu yaqūlu: thumma inqadat tilka al-sin̄̄n wa-abluhälfa-ka-annahā wa-ka-annahum ablām'. Ibn Aws' phrase was also cited by 'Imād al-Dīn al-Ișfahānī in the introduction to his al-Barq al-Shāmì (al-Bundārī, Sanā, 53).

42 Ibn Manẓūr, Lisān, entry $f-r-j$, II, 343.

43 Pouzet (1991), 380-1.

44 See for example the entry $f-r-j$ in Ibn Manẓūr, Lisān, II, 341-4.

45 Ibn Wāṣil, Mufarrij, I, 271. The use of grammatically different forms of the same root was due to the demand of rhyme and symmetry. Not in Abū Shāma, Rawdatayn.

46 Ibn Wāṣil, Mufarrij, V, 261: 'an yufarrija 'anhu mā buwa fīhi min al-d̄̄q', similar at V, 263.

47 Ibn Wāșil, Mufarrij, V, 264: 'lam yusma' bi-nażīiibi fī shay' min al-tawārīkh, wa-kānat

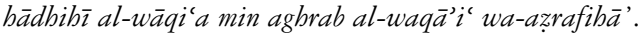

48 "laqad hamā al-dīna wa-al-dunyā wa-ablabumä/wazīrubu al-Ṣäliḥ" al-farrāj" lil-ghumam al-läbis" al-fakbr lam tansij ghalà'ilabulillā yad" al-șan'atayn al-sayf ${ }^{i}$ wa-al-qalam'. In Abū Shāma, Rawḍatayn, II, 301.

49 This differentiation was based on the fact that the caliph was 5 years old at his accession to power. The vizier acted as his regent.

50 Ibn Wāṣil, Mufarrij, III, 53. Not in Abū Shāma, Rawḍatayn.

51 Ibn Wāṣil, Mufarrij, I, 1: 'akbbār mulūk ban̄̄ Ayyūb wa-jumla min mahāsinibim wa-manāqibibim.

52 Ibn Wāșil, Mufarrij, IV, 181. This was meant especially to delimit the Ayyubids from the Saljuqs who are criticized explicitly for killings within the family, for example, Ibn Wāṣil, Mufarrij, IV, 140 and IV, 219.

53 Ibn Wāṣil, Mufarrij, V, 110, criticizing al-Malik al-Kāmil (d. 635/1238) for ill treatment of prisoners.

54 Ibn Wāṣil, Mufarrij, Paris BN, arabe 1703, fol. 94b and Paris BN, arabe 1702, fol. 375b.

55 Ibn Wāṣil, Mufarrij, Paris BN, arabe 1703, fol. 112b; not in Paris BN, arabe 1702.

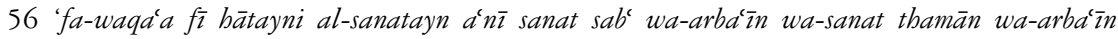

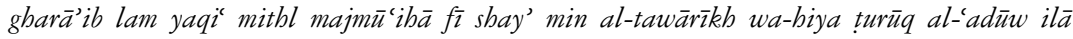
al-bilād fī al-kathra al-'azìma wa-tamakkunubum min thaghribā fì yawm wābid wa-mawt

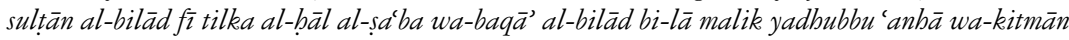
mawtibi thalāthat ashbur wa-al-khutba wa-al-sikka bāqatān la-bu fī țül tilka al-mudda [...] wa-iqāmat imra'a fī al-mulk maqāmabu wa-al-khutba la-hā 'alā al-manābir wa-khurūj 
al-tawāqī' wa-'alayhā 'alāmatubā wa-lam yajri bi-dhālika 'ādat'an fī al-islām thumma khal' uhā min al-salțana wa-iqāmat sulțān thumma kbal' dhālika al-sultān wa-iqāmat sultān ba'dahu li-khamsat ayyām thumma al-da'wa li-sultān laysa fī al-bilād thumma ibtāal dhālika [...]'. (With slight variations in Paris $\mathrm{BN}$, arabe 1702, fol. 377b.)

57 This insecurity is not only the product of considering the period in hindsight, but was current in Hama during this period. This is, for example, visible in an anecdote reported in the supplement to the Mufarrij: a single letter written to Egypt including embarrassing details on the rule in Hama could have brought down the dynasty (Ibn al-Mughayzil, Dhayl, Paris BN, arabe 1703, fols. 192a/b).

58 The text of the Nuzha itself is lost and it has survived only in citations, on which the 1992 edition is based. It is therefore difficult to establish further layers of meaning by a closer reading of the text, especially as the introduction has not survived.

59 See quote in introduction to edition of Abū Shāma, 'Uyūn, I, 139: 'qaharā al-'ibād'.

60 Abū Shāma, Rawḍatayn, IV, 405: 'faṣl fī inqisām mamālikibi bayna awlādihi wa-ikhwatihi'.

61 Ibn Wāṣil, Mufarrij, III, 3: 'dhikr mā istaqarrat al-hāl 'alaybi min al-mamālik ba'da wafāt al-Sulțān rabimahu Allāb'.

62 Ibn Wāṣil, Mufarrij, III, 3-5.

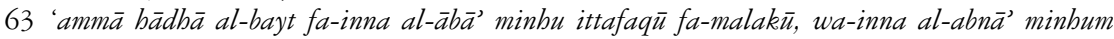

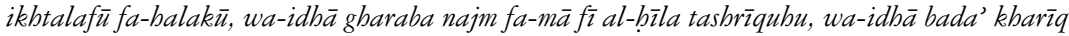
thawb fa-mā yalībi illā tamzīqubu, wa-haybātu an yusadda 'al̄̄ qadar tarīqubu wa-qad quddira turūqubu, wa-idhā kāna Allāh ma'a khaṣm 'alā khaṣm fa-man kāna Allāh ma'ahu fa-man yutīqubu'. The last events included in this first version took place in the year 592/1196.

64 Abū Shāma, Rawḍatayn, I, 31: 'thumma inqadat tilka al-sinūn wa-ablubālfa-ka-annahā wa-ka-annabum aḅlam'. Not in Ibn Wāṣil, Mufarrij.

65 In the Rawdatayn's summary, 'Uyzun, the narrative was indeed brought to an end with the death of Salāh al-Dīn.

66 Ibn Shaddād, Nawādir, 246-8.

67 See for example the year 596/1199-1200, which consisted mainly of obituary notices, especially for al-Qāḍ̄i al-Fāḍil (Abū Shāma, Rawḍatayn, IV, 464-83).

68 Abū Shāma, Rawḍatayn, IV, 483-5.

69 Ibn Wāṣil, Mufarrij, III, 116.

70 'wa-tuwuffiya al-Malik al-Af̣al bi-Sumaysāt fì sanat 622 wa-bumila ilà Halab fa-dufina bi-hā wa-tuwuffiya al-Malik al-Zāhir bi-Halab fì sanat 613 wa-fīhà tuwuffiya bi-Dimashq al-Shaykh

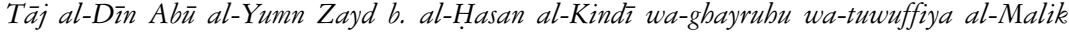

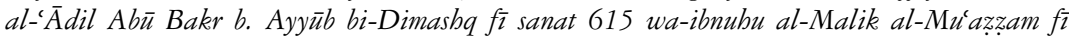
awākhir sanat 624 wa-ibnāhu al-Ashraf wa-al-Kāmil fì sanat 635 rabimabum Allāh ta'ālā wa-waffaqa man baqiya min abl baytibim wa-așlaḅa dhāt baynibim amīn'.

71 This perhaps explains the choice of the Dhayl's editor to publish the work under a different title: Biographies of the Men of the Sixth and the Seventh Centuries, Known as the Supplement to the Rawdatayn.

72 Ahmad (1962), 93.

73 'kullamā qultu dawlat al-ḅākim al-jābir/zālat qāmat' alaynā ukhrā' (Abū Shāma, Dhayl, 225).

74 Abū Shāma, Dhayl, 164-5.

75 Ibn Wāṣil, Mufarrij, V, 112-35.

76 Ibn al-Mughayzil, Dhayl, Paris BN, arabe 1703, fol. 172a. The final event, the appointment of Burhān al-Dīn al-Khị̂ir (d. 739/1339) as qāẹ̄ in Miṣr (Cairo), was wrongly dated, as he was appointed in 661/1262. However, the passage as a whole referred to events in the year 659 .

77 Ibn al-Mughayzil, Dhayl, Paris BN, arabe 1702, fol. 425a.

78 In the two manuscripts, which include this supplement, the starting year was either 659 or 662 (depending on the end of Ibn Wāșil's narrative in the two manuscripts) and the years covered extended up to 680 (Paris BN, arabe 1702) or 695 (Paris BN, arabe 1703). 
79 See Chapter 3.

80 The problem of authorship is raised by the two quite different formats of these supplements in general, and by this insertion (which is unique to Ibn al-Mughayzil, Dhayl, Paris BN, arabe 1702) specifically. However, a characteristic of the parts common to both manuscripts is the inclusion of important passages linked to 'Alī b. 'Abd al-Rahīm Ibn al-Mughayzil's maternal grandfather Sharaf al-Din al-Anșārī. The fact that such passages are also to be found in this insertion on Baybars validates the assumptions that it was indeed included and reworked by 'Alī b. 'Abd al-Rahīm himself.

81 The relevant section in Ibn al-Mughayzil, Dhayl, Paris BN, arabe 1702 (fols. 395a-424a) corresponds to the pages 110-76 of the Rawd's 1976 edition. The texts are largely similar, apart from three insertions by the supplement's author. These insertions deal in two instances with the maternal grandfather of the writer being on a mission in Egypt (fols. 404a/404b and 411a-412a) and a section including a poem by the historian Ibn al-'Ádim describing the Mongol destructions in Aleppo as well as obituary notices for him and the religious scholar Ibn 'Abd al-Salām (fols. 406b-408b).

82 Al-Nāșir (2002) argues that the editions of The Radiant Garden are in fact only based on a summary of the text written by Ibn al-Qaysarānī (d. 707/1307), another Egyptian secretary. His argument being possible but not conclusive, I prefer to retain Ibn 'Abd al-Zāhir as the original author of the passage discussed here.

83 This can be compared to the image of ancient history as depicted in French medieval historical writing, which liberated the nobility from its dependence on clerics since chivalric values became atemporal and universal (Spiegel (1993), 101-9).

84 Donner (1998), 112-22.

85 Lambton (1981), 17.

86 Watt (1968), 86-7.

87 Smith et al. (1998), especially 25, for the myth of Golden Age.

88 Schöpflin (1997), 20.

89 Al-Azmeh (1997), 65.

90 On the role and development of Jerusalem in this context, see Hillenbrand (1999), 150-61 and 188-92.

91 Ibn Wāṣil, Mufarrij, II, 233. Same at Abū Shāma, Rawḍatayn, III, 371.

92 Ibn Wāṣil, Mufarrij, II, 234. Same at Abū Shāma, Rawḍatayn, III, 382.

93 Ibn Wāṣil, Mufarrij, II, 203. Same at Abū Shāma, Rawḍatayn, III, 319.

94 Ibn Wāṣil, Mufarrij, I, 285. Similar to Abū Shāma, Rawḍatayn, I, 75.

95 Ibn Wāṣil, Mufarrij, II, 193. Not in Abū Shāma, Rawḍatayn.

96 Ibn Wāṣil, Mufarrij, III, 69. Not in the passage on these events at Abū Shāma, Rawdatayn, IV, 431-2.

97 Ibn Wāṣil, Mufarrij, V, 108: 'law kunta fī yawm al-Saqîfa hāḍir an/kunta al-muqaddam wa-al-imām al-arwa' $\bar{a}$ '. 'Saqifa' referred to the negotiations in $11 / 632$ preceding the nomination of Abū Bakr as successor of the Prophet Muhammad in the leadership of the community.

98 Ibn Wāṣil, Mufarrij, V, 108-9. Not in Abū Shāma, Rawḍatayn.

99 Abū Shāma, Rawḍatayn, IV, 396. Not in Ibn Wāṣil, Mufarrij.

100 Abū Shāma, Rawḍatayn, III, 308: 'fa-ka-anna Rasūl Allāb [invocation] sayyara lil-faq̄̄̄r ilā nuṣratibi’. Not in Ibn Wāṣil, Mufarrij.

101 Abū Shāma, Rawḍatayn, II, 268. Not in Ibn Wāșil, Mufarrij.

102 Abū Shāma, Rawḍatayn, I, 26. Not in Ibn Wāṣil, Mufarrij.

103 Abū Shāma, Rawḍatayn, II, 20; Abū Shāma, Rawḍatayn, II, 59. Not in Ibn Wāṣil, Mufarrij.

104 Abū Shāma, Rawḍatayn, IV, 364: 'wa-kāna yawm an lam yusib al-islām wa-al-Muslimūn bi-mithlibi mundhu fuqida al-khulafā' al-rashidūn'. Not in Ibn Wāșil, Mufarrij.

105 Abū Shāma, Rawḍatayn, III, 351. Not in Ibn Wāṣil, Mufarrij.

106 Abū Shāma, Rawḍatayn, I, 37. Not in Ibn Wāṣil, Mufarrij. 
107 Abū Shāma, Dhayl, 200.

108 Assmann (1992), 78-80.

109 Mottahedeh (1994), 17-18.

110 The status of Alexander as a Prophet was disputed in Islamic tradition (Watt, W.M. in: EI2 (CD-Rom version) 'Iskandar').

111 Haarmann (1996), 607-8.

112 Springberg-Hinsen (1989), 123, citing the example of 'Abd al-Malik b. Muhammad al-Tha'ālibì’s (d. 429/1038) universal history.

113 For example: Ibn Wāṣil, Mufarrij, I, 149; II, 65; II, 235 and Abū Shāma, Rawḍatayn, II, 11; II, 126; II, 153; II, 194; II, 474.

114 Based on Quran 12:99-101. The formulation of this scene by Ibn Shaddād, Nawādir, 44, was taken over by Abū Shāma, Rawḍatayn, II, 148-53, and made more explicit by Ibn Wāsil, Mufarrij, I, 185-8, by citing the relevant Quranic verses.

115 Abū Shāma, Rawḍatayn, I, 12 and 93; II, 43.

116 Abū Shāma, Rawdatayn, III, 370.

117 With regard to Shāwar (d. 564/1169), the Fatimid vizier, see Abū Shāma, Rawḍatayn, II, 22 and II, 127. With regard to the Holy Roman Emperor Frederick I Barbarossa (malik al-almān) (d. 1190), see Abū Shāma, Rawḍatayn, IV, 193.

118 Springberg-Hinsen (1989), 118-21.

119 Morony, M. in: EI2 (CD-Rom version) 'Kisrā'.

120 Abū Shāma, Rawḍatayn, II, 123 (including also Nūr al-Dīn's superiority over Iskandar).

121 Abū Shāma, Rawḍatayn, III, 8.

122 With regard to the Damascene Ayyubid al-Malik al-Ashraf Mūsā (d. 635/1237), see Ibn Wāṣil, Mufarrij, III, 158. With regard to al-Malik al-Șāliḥ Najm al-Dīn, see Ibn Wāṣil, Mufarrij, Paris BN, arabe 1703, fol. 67a and Paris BN, arabe 1702, fol. 360a.

123 Ibn Wāṣil, Mufarrij, V, 177: '[...] Hịms kānat la-hā malika fī qadīm al-zamān fa-kānat taqta'u al-'Āssì'.

124 Ibn Wāṣil, Mufarrij, II, 407, on the Șalāhīya Madrasa.

125 Ibn Wāṣil, Mufarrij, Paris BN, arabe 1703, fol. 146b and Paris BN, arabe 1702, fol. 392b.

126 Ibn Wāṣil, Mufarrij, IV, 249-51.

127 Ibn Wāṣil, Mufarrij, Paris BN, arabe 1703, fol. 62b and Paris BN, arabe 1702, fol. 355b.

128 Ibn Wāșil, Mufarrij, IV, 36-9.

129 Hawting, G. in: EI2 (CD-Rom version) 'Umayyads'.

130 El-Hibri (1999), 25.

131 Abū Shāma, Rawḍatayn, II, 314. Not in Ibn Wāṣil's section on Nūr al-Dīn's asceticism, Mufarrij, I, 264-6.

132 Abū Shāma, Rawḍatayn, III, 91: 'wa-yaqūmu fīhā maqūm al-Rashīd wa-yaqūmu 'Al̄̄hi wa-'Uthmānubu maqām waladaybi al-Ma'mūn wa-al-Amīn'. In Ibn Wāṣil, Mufarrij, II, 112, the voyage and the auditing were mentioned, but the link to Hārūn al-Rashīd was missing.

133 Ibn Wāsil, Mufarrij, IV, 155-6. At the death of his later patron al-Malik al-Mu'azzam Tūrānshāh, Ibn Wāṣil re-employed the image of the 'caliph of one day': Ibn Wāṣil, Mufarrij, Paris BN, arabe 1703, fol. 90a; not in Paris BN, arabe 1702.

134 See Ibn al-Athīr, Kāmil, VII, 414-15.

135 Ibn Wāșil, Mufarrij, Paris BN, arabe 1703, fols. 102a-105b and Paris BN, arabe 1702, fols. 380a-383a.

136 Little information on this secretary is available. The obituary notice in Abū Shāma, Dhayl, 175, consisted of one line, and the notice in al-Dhahabī, Ta'rīkh, years 641-50, 199, was based on Abū Shāma's words.

137 See overview by Ahmad (1956), 59.

138 Al-Bundārī, Sanā, 53 and Abū Shāma, Rawḍatayn, I, 31.

139 Al-Bundārī, Sanā, 53: 'iqtasama awlādubu mamālikahu'.

140 Al-Bundārī, Sanā, 52: 'wa-mā asra' mā inqadat wa-infaradat tilka al-layāt̄̄ wa-al-ayyām wa-al-shubūr wa-al-a'wām'. 
141 Khalidi (1994), 182-8.

142 'Imād al-Dīn, Fath, 6.

143 Al-Bundārī, Sanā, 53-5.

144 Richter-Bernburg (1998), 197.

\section{TEXTUAL AGENCY II: MICRO-ARRANGEMENT, MOTIFS AND POLITICAL THOUGHT}

1 On this style, see Rosenthal (1968), 66-71 and Donner (1998), 255-71. By the seventh/ thirteenth century this style had undergone decisive changes such as for example the disappearance of the isnād.

2 For early historical writing, see the discussion of this issue in Humphreys (1995), 71-6.

3 Ahmad (1956), 36.

4 Cahen (1940), 67.

5 Ahmad (1962), 92-3.

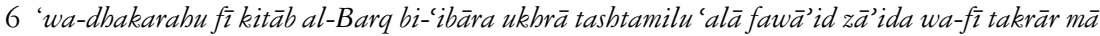
taqaddama aydān bi-ghayr tilka al-'ibāra fä'idat ${ }^{u n}$ fa-innabā ma'ān ${ }^{i n} j a l \bar{l} l a t^{u n}$ kullamā kurrirat bullat'.

7 Abū Shāma, Rawḍatayn, III, 111-25.

8 Ibn Wāșil, Mufarrij, II, 115-23.

9 Abū Shāma, Rawḍatayn, III, 115: 'fa-qadamnā 'alā baḅr lā yasuddubu illā baḅr'.

10 Abū Shāma, Rawḍatayn, III, 116: 'wa-wașala al-baḅr ilā al-Furāt'.

11 Abū Shāma, Raw ḍatayn, III, 116-22.

12 Abū Shāma, Rawḍatayn, III, 117: 'fa-tilka al-a'māl ka-al-bijra'.

13 Abū Shāma, Rawḍatayn, III, 117: 'wa-qarrabahu min mahall Dār al-Salām bal al-islām'.

14 Abū Shāma, Rawḍatayn, III, 118-20.

15 Abū Shāma, Rawḍatayn, III, 119, citing Quran 58:22 that Muslims do not ally with those counteracting the Prophet and God.

16 Abū Shāma, Rawḍatayn, III, 121, citing Quran 9:35 condemning those turned towards the richness of this world.

17 Ibn Wāṣil, Mufarrij, II, 179-80.

18 Ibn Wāṣil, Mufarrij, II, 35 and repeated on 174-5.

19 Ibn Wāșil, Mufarrij, II, 263. French: 'Saône', twenty-five kilometres north-east of the Syrian town of Latakiya.

20 Ibn Wāṣil, Mufarrij, II, 121: 'qātalanā abl" al-Mawșil bi-hamāqāa [...] wa-alqā al-madās wa-halafa annabu là ya' üdu yuqātilu anafat tan haythu duriba bi-al-madās'.

21 Ibn Shaddād, Nawādir, 56-7; Ibn al-Athīr, Kāmil, XI, 482-7 and al-Bāhir, 183, where the siege of Mosul played merely a marginal role. 'Imād al-Dīn, Barq, V, 17-40, tended towards a more fragmented narrative, for example by including a decree of nomination (31-2).

22 See for example, the extended biography of the poet in Ibn Wāșil, Mufarrij, V, 41-8.

23 This poet was also excluded from 'Imād al-Dīn al-Iṣfahānì's anthology of Arab poets of the sixth/twelfth century, Kharīdat al-qașr, arguably because of his criticism of Șalāh al-Dīn and his men (Richter-Bernburg (1998), 110-11).

24 Ibn Wāṣil, Mufarrij, I, 98-100; Abū Shāma, Rawḍatayn, I, 154-6. Castle Ja'bar is on the left bank of the middle Euphrates.

25 In this passage Abū Shāma relied on Ibn al-Athīr, Bāhir, 74-6. However, he significantly changed the structure of the narrative by introducing his own comments and extracts from other sources, as well as rearranging the sequence of the passages taken from Ibn al-Athīr.

26 For 'Imād al-Dīn's career and his depiction in contemporary sources, see Hillenbrand (2001).

27 Ibn Wāṣil, Mufarrij, I, 104; Abū Shāma, Rawḍatayn, I, 161.

28 Abū Shāma, Rawḍatayn, I, 121. Not in Ibn Wāṣil, Mufarrij.

29 Abū Shāma, Rawḍatayn, IV, 66. 
30 For example: Abū Shāma, Rawdatayn, I, 110-11 (death of Ahmad al-Mustazhir Billāh in 512/1118) and Abū Shāma, Rawḍatayn, II, 178-9 (death of Yūsuf al-Mustanjid Billāh in 566/1170).

31 Abū Shāma, Rawḍatayn, I, 140-1. Not in Ibn Wāṣil, Mufarrij.

32 Present day Cizre in south-eastern Turkey.

33 Ibn Wāṣil, Mufarrij, I, 34-5. Not in Abū Shāma, Rawḍatayn.

34 Ibn Wāṣil, Mufarrij, I, 86. Not in Abū Shāma, Rawḍatayn.

35 Ibn Wāṣil, Mufarrij, I, 42: 'wa-lā shay' aqbah min al-ghadr'. Not in Abū Shāma, Rawdatayn.

36 Ibn Wāṣil, Mufarrij, Paris BN, arabe 1703, fols. 114b/115a.

37 Ibn Wāșil, Mufarrij, Paris BN, arabe 1703, fols. 130b/131a.

38 Ibn Wāṣil, Mufarrij, V, 363-8.

39 Abū Shāma, Rawḍatayn, I, 23: 'min al-anbiyā' wa-al-mursalīn wa-al-șabāba wa-al-tābìīn

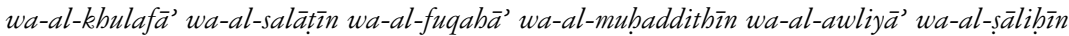
wa-al-shu'arā' wa-al-nabwīìn'in'.

40 Abū Shāma, Rawḍatayn, I, 37: 'fa-buwa [Nūr al-Dīn] jaddada lil-mulük ittibā' sunnat al-'adl [...] fa-innabum [al-mulūk] kānū qablabu ka-al-jāhilīya'.

41 Abū Shāma, Rawḍatayn, I, 40: 'wa-min 'adlibi annabu lam yu'āqib al-uqūba allatī yu'āqibu bi-hā al-mulūk fì hādhibī al-a'șār 'alā al-zinna wa-al-tubma'.

42 Abū Shāma, Rawḍatayn, I, 172.

43 Ibn Wāṣil, Mufarrij, I, 49: 'mulūk al-ard'.

44 Ibn Wāṣil, Mufarrij, I, 233: 'wa-hamala ilaybi māa yal̄̄qu an yubmala ilā al-mulūk'.

45 'wa-kānat wāqi' at 'Imād al-Dīn shabīhat an bi-wāqi'at Balak wa-man ta'ālā 'alā Allāh ta'ālā akdhabahu wa-qad warada bikâyat 'an 'an Allāb ta'ālā: anā Allāb rabb Makka lā atamamtu li-muqadhdhir amran'. The source for this quote is not clear: it is neither Quranic nor does it seem to be a hadīth qudsī. It is not included in the collections of such hadīths and the text lacks the obligatory introduction where the Prophet Muhammad is mentioned. I was not able to identify it as a quote from a pre-Islamic text of revelation.

46 Ibn Wāșil, Mufarrij, IV, 306-7, referring to Shams al-Dīn's siege of this town in Azerbaijan in 627/1229-30: 'qat' al-tarīq'.

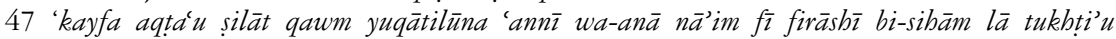

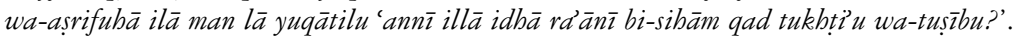

48 Abū Shāma, Rawḍatayn, I, 155: "idda min kbuddāmibi al-șibāh wa-buwa yahibbubum”. Not in Ibn Wāșil, Mufarrij.

49 For poetry, see for example the panegyric for al-Malik al-Ashraf Mūsā (d. 635/1237) in Ibn Wāṣil, Mufarrij, III, 157:

'When the branch bends over its sandhill/I aid my heart by his cut promenade I partake of its juice and its pieces/Sweetest of wines and perfumes.'

(Translation Wormhoudt (1974), 13)

For the instrumental use see, for example, the deposition of the caliph al-Manșūr al-Rāshid in 530/1136. (Ibn Wāṣil, Mufarrij, I, 67. Not mentioned in Abū Shāma, Rawdatayn, I, 121, in the respective report.)

50 Situated in the south-east of present-day Syria.

51 Abū Shāma, Rawḍatayn, I, 437-40; Ibn Wāṣil, Mufarrij, I, 146-7.

52 The date of Nuṣrat al-Dīn's death is unknown. Sibt Ibn al-Jawzīe Mir'āt, VIII(1), 252 and al-Dhahabī, Ta'rīkh, years 551-60, 306, stated that he had died during or shortly after the siege of Bāniyās. Al-Ṣafadī, Wāiñ, IX, 384-5, stated that different versions of his date of death existed, without specifying an alternative date. Abū Shāma, Rawḍatayn, II, 413-14, had him still alive eleven years after the siege in 571/1176.

53 Abū Shāma, Rawḍatayn, I, 437; Ibn Wāṣil, Mufarrij, I, 146: 'law kushifa la-ka 'an al-ajr alladhī üiddu la-ka la-tamannayta an tadhbaba al-ukbrä. 
54 Elisséeff (1967), 596, n. 1.

55 Sibṭ b. al-Jawzī, Mir’āt, VIII(1), 252; Ibn al-'Adīm, Zubdat, II, 321; Ibn al-Athīr, Kāmil, XI, 304-5 and Ibn al-Athīr, al-Bāhir, 130-1.

56 Elisséeff (1967), 596, argues that during that period he was still in Konya.

57 Khayat (1971), 190-1.

58 Such a positive meaning attached to the loss of the second eye was a common literary figure in formative and medieval historical writing. See for example Abū al-'Asūs's lines during the battle at Siffīn in the year 37/657, where he expressed the wish to lose his second eye (al-Tabarī, History (English translation G. Hawting), XVII, 56-7).

59 Abū Shāma, Rawḍatayn, I, 437: 'wa-ibn alladhī zalzala min khawfihi/mā bayna Aghmāt [town in southern Morocco] ilā al-Ṣ̂̀n'.

60 'wa-kāna akbūbu Nușrat al-Dīn ma'a al-Franj fa-lammā 'āyana a'lām Nūr al-Dīn lā yatamāsak an hamala bi-jam̄̄ aṣhābibi qāṣid ${ }^{a n}$ akbābu Nūr al-Dīn fa-lammā qaruba minhu nazala wa-qabbala al-ard bayna yadaybi fa-lam yaltafit 'alaybi fa-tamma 'alà wajbibi'. Not in Ibn Wāṣil, Mufarrij. Abū Shāma cited here the lost work of the Shiite author Ibn Abī Tayy.

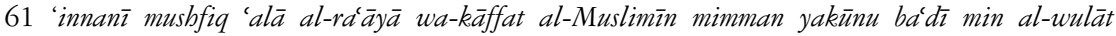

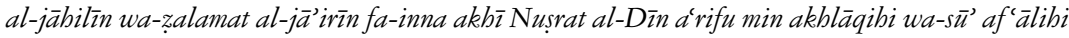
$m \bar{a}$ lā artad̄̄ máabu bi-tawliyatibi amrin min umūr al-Muslimīn'. Not in Ibn Wāșil, Mufarrij.

62 Abū Shāma, Rawḍatayn, I, 440: 'fa-iltafata ilaybi wa-qāla la-bu lil-nās bi-bādhā al-fath farḅa wāhida wa-la-ka farḅatān fa-qāla kayfa dhālika? qāla li-anna Allāh tāiāā al-yawm barrada jildat wālidika min nār jahannam'.

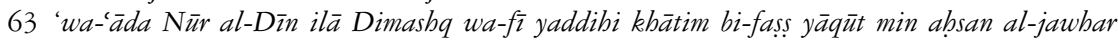

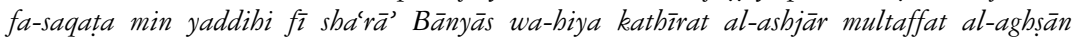

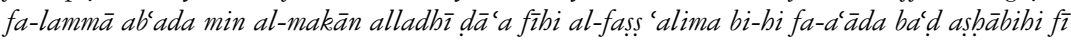

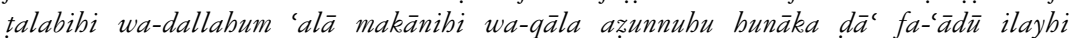
fa-wajadūbu'. The differences in Ibn Wāșil's version of this scene are slight, for example, use of plural and singular.

64 Allan, J./Sourdel, D. in: EI2 (CD-Rom version) 'Khātam/Khātim'.

65 This anecdote was evidently still included into seventh-/thirteenth-century chronicles such as Ibn al-Athīr, Kāmil, III, 113.

66 Al-Tabarī, History (Engl. translation A. Brockett), XXVI, 62-4.

67 Levi Della Vida, G./Khoury, R.G. in: EI2 (CD-Rom version) ' Uthmān b. 'Affān'.

68 'labisat bi-Nūr al-Dīn nawr hadā'iq/thamarātubunna gharā'ib al-af̣̣all'. The subject of the first phrase is the 'noble and Mahmūdian rule' (dawla gharrā' Mabmūì̄ya) from same page, line 6. (Abū Shāma, Rawḍatayn, I, 439.)

69 Abū Shāma, Rawḍatayn, I, 439: 'wa-mimmā yunāsibu hādhā al-sa'āda [...]'.

70 Abū Shāma, Rawḍatayn, I, 439: 'fa-'udda dhālika min sa'ādat al-Rashīd wa-baqā' mulkihi'.

71 Kennedy (1986), 139-41.

72 Wolf (1995).

73 Spiegel (1993).

74 See also the contributions to Gleba (2000), which discuss how medieval European historiography was employed - beyond the authorial intentions - for differing ends by various audiences.

75 Goetz (1992), 72.

76 Spiegel (1993), 5.

77 Here Rosenthal, E. (1958), Lambton (1981), Nagel (1981) and Black (2001) are the central studies.

78 In the same vein, Spiegel (1997c) proposes European medieval historical writing as a source for political theory. For the period dealt with in the present study, Holt (1980) and (1995) propose a similar reading for royal biographies, such as Ibn Shaddād's al-Nawādir al-sultān̄ìya.

79 El-Hibri (1999), 29. 
80 Abū Shāma, Rawḍatayn, I, 26: 'fa-la'alla yaqifu 'alaybi min al-mulük man yasluku fī wilāyatibi dhālika al-sulūk [...] wa-bākadhā aqūlu bādhāni bujjat" 'alā al-muta'akbkhirīn min al-mulūk wa-al-salātìn'.

81 Abū Shāma, 'Uyūn, I, 180: 'idh kāna mu'zam qașd̄̄ bi-dhālika al-kitāb tanhīẹ bimam

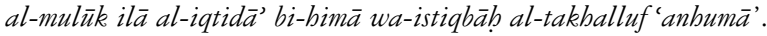

82 'fa-inna fì mutāla'at kutub al-tawārīkh mu'tabar an wa-fì dhikribā 'an al-ghurūr muzdajir ${ }^{a n} l \bar{a}$ sìyamā idhā dhukira ba'd man māta fì kull 'āmm min al-ma'ārif wa-al-ikhwān wa-al-aqārib wa-al-jīrān wa-dhawī al-tharwa wa-al-sultān. fa-inna dhälika mimmā yuzabbidu dhawī

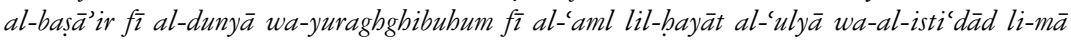
hum mulāqūhu wa-al-iqlā' 'ammā bum 'an qal̄̄l mufāriqūhu'.

83 Ibn Wāṣil, Mufarrij, I, 135: 'wa-hākadhā fa-li-takun al-mulūk'.

84 Ibn Wāṣil, Mufarrij, II, 277: 'fa-mithl hādhā li-yakun al-sulțān'.

85 Ibn Wāṣil, Mufarrij, V, 139: 'wa-lam nasmi' anna abad 'an min al-mulūk wa-al-'uzamà' ba'da $\bar{A} l$ Barmak fa'ala fi'lahu fì al-tawassu' fì al-'ațā’ wa-al-karam'.

86 Lambton (1981), 51-4.

87 Lambton (1981), 107-29. For a detailed discussion of al-Ghazālì's political thought, see Hillenbrand (1988).

88 The eighth-/fourteenth-century copyist of BL, or. 1538, Muhammad b. Ahmad b. Muhammad al-Hä'îm stated that he received an ijāza for this and other works by Abū Shāma from some shaykhs, such as Abū Ishāàq al-Ibrāhīmān b. M. b. 'Abd al-Rahịm al-Lakhmī (d. 790/1388) who had read them with the Cairene chief judge.

89 On Ibn Jamāea's political thought, see Rosenthal, E. (1958), 43-51; Lambton (1981), 138-43; Nagel (1981), I, 436-40; Black (2001), 143-4.

90 'The act by which a certain number of persons, acting individually or collectively, recognize the authority of another person' (Tyan, E. in: EI2 (CD-Rom version) 'Bay'a').

91 Ibn Jamāac, Tahrīir, 359.

92 Starting points for Ibn Taymīya's political thought are Laoust (1948), XI-XLVIII; Rosenthal, E. (1958), 51-61; Lambton (1981), 143-51; Nagel (1981), II, 109-40; Black (2001), 154-9.

93 The proximity between these two authors is partly also seen in terminological similarities when, for instance, Abū Shāma praised Ṣalāh al-Dīn for his practice of ruling his subjects by 'sharī'at al-siyāsa'.

94 Discussed in Garcin (1967).

95 Black (2001), 144.

96 Elisséeff (1967), 678-81.

97 Ibn Wāșil, Mufarrij, I, 233: 'thumma sāra Nūr al-Dīn ilā mamlakat al-Sulțān 'Izz al-Dīn Qilij Arslan b. Mas'ūd b. Qilij Arslan b. Sulaymān b. Qutlumush al-Saljūqū șābị Qūniya 'āzim an 'alā harbibi wa-akbdh al-bilād minbu'.

98 Abū Shāma, Rawḍatayn, II, 260: 'wa-sāra Nur al-Dīn qāsid jan jānib al-shimāl li-tasd $\bar{\imath} d$ māa ikbtalla bunāka min al-abwāl'. Unless stated otherwise the following elements of this report are not in Ibn Wāṣil, Mufarrij.

99 Abū Shāma, Rawḍatayn, II, 261: 'wa-mā fì al-anām karīm siwāhu'.

100 On the development of the idea of jihād during the Crusading period, see Hillenbrand (1999), especially 116-41, for Nūr al-Dīn's period.

101 There is no known legalistic text from Syria and Egypt in the seventh/thirteenth century on the subject of ideal rule. It is therefore impossible to consider the relationship between the ideas expressed in the chronicles and legalistic texts contemporary to them. The text closest to this period was written in the eastern lands by Fakhr al-Dinn Rāzi (d. 606/1209). It was less concerned with the regionalization of power than with the question of how the separation between temporal and religious power could be recognized without abandoning the concept of the imam as the ideal ruler (Lambton (1981), 131-7). 


\section{RECEPTION AFTER THE SEVENTH/THIRTEENTH CENTURY}

1 Quotations of Ibn Wāsil's Mufarrij are to be found, among other sources, in the works of his student al-Malik al-Șālih al-Mu’ayyad Abū al-Fidā', al-Mukhtașar fī tàrīkh al-bashar, alDhahabī's Tàrìkh al-Islām, al-Kutubīs Fawāt al-wafayāt and Ibn Khaldūn's Kitāb al-ibar.

2 Ibn Wāșil, Mufarrij, Istanbul, Süleymaniye Kütüphanesi: Molla Çelebi Collection no. 119, fol. 1a (reproduced in editor's introduction to Ibn Wāṣil, Mufarrij, I, 14): the invocation after the name of Ibn Wāșil reads: "afā Allāh 'anhu'.

3 Ibn al-Mughayzil, Dhayl, Paris BN, arabe 1703, fol. 172a: the invocation after Ibn Wāṣil's name at the start of the supplement reads: 'matta'a Allāh ta'älā bi-hayātihi'. In contrast, the same passage reads in Ibn al-Mughayzil, Dhayl, Paris BN, arabe 1702, fol. 425a: 'rabimahu Allāb'.

4 Editor's introduction to Ibn Wāṣil, Mufarrij, I, 8.

5 According to the colophon, it was copied in 821/1418 (Ibn al-Mughayzil, Dhayl, Paris $\mathrm{BN}$, arabe 1702 , fol. 442a).

6 For these notes, see editors' introduction to Ibn Wāṣil, Mufarrij, I, 13-15 and III, Section 6.

7 For example Ibn Wāṣil, Mufarrij, Paris BN, arabe 1702, fol. 375b: 'wa-qāla al-qādi Jamāl al-Dīn b. Wāṣil șāhib hādhā al-ta'rīkh [...]'.

8 Ibn Wāṣil, Mufarrij, Istanbul, Süleymaniye Kütüphanesi: Molla Çelebi Collection no. 119 (cited in editors' introduction to Ibn Wāsil, Mufarrij, I, 14 and III, Section 6):

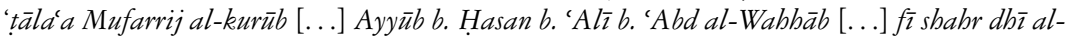
qa['da sanat] arba'a [wa-tham] ānīn wa-sab'a mi'a [...]'. and 'nazara fī hāadha al-ta'rìkh [...] Mubammad b. al-marbūm Hasan [...] fì ta'rīkh al-rābi' wa-al-'ashrūn min rabī' al-awwal sanat sab' wa-sab'in wa-thamān mi'a [...]'.

9 The analysis of reading and transmission notes for the manuscripts of the Mufarrij is incomplete because 2 of the 4 manuscripts have no title page (Paris BN, arabe 1702 and Paris $\mathrm{BN}$, arabe 1703). However, of 2 surviving title pages 1 does not contain any such notes (Cambridge, no. 1079) and the other contains only the 2 reading notes (Istanbul, Süleymaniye Kütüphanesi: Molla Çelebi Collection no. 119, reproduced in editor's introduction to Ibn Wāșil, Mufarrij, I, 14-15) which allows this conclusion.

10 Al-Șafadī, Wāê̄, III, 85-6: Abū Ḥayyān Muhammad b. Yūsuf (d. 745/1344) when Ibn Wāṣil took the opportunity of a mission with his patron al-Malik al-Muzaffar Mạmūd of Hama (d. 698/1299) to Cairo to teach his works there.

11 Ibn al-Mughayzil, Dhayl, Paris BN, arabe 1703, fol. 172a and Paris BN, arabe 1702, fol. $425 \mathrm{a}$.

12 Editor's introduction to Ibn Wāṣil, Mufarrij, I, 9-11.

13 Ibn Wāṣil, Mufarrij, Istanbul, Süleymaniye Kütüphanesi: Molla Çelebi Collection no. 119 (cited in the editor's introduction to Ibn Wāṣil, Mufarrij, I, 14).

14 Ibn Wāṣil, Mufarrij, Paris BN, arabe 1703. The note is also transcribed in the editor's introduction to the edition Ibn Wāșil, Mufarrij, I, 13.

15 For details, see Ahmad (1956), 44-50, in combination with the introduction by al-Zībaq (1997) to his edition of the Rawdatayn.

16 Two manuscripts were copied in the seventh/thirteenth century and three in the eighth/ fourteenth century. For three further manuscripts the exact date is not identifiable. Ahmad (1956), 44-8, argues that they were copied in the same period.

17 Abū Shāma, Rawḍatayn, Bodleian, Clark 7, fol. 2a.

18 Abū Shāma, Rawḍatayn, BL, Add 7312, fol. 1a.

19 Abū Shāma, Rawḍatayn, Berlin, WE. 127, fol. 1a.

20 Abū Shāma, Dhayl, 41-2.

21 Abū Shāma, Dhayl, 187: 'wa-fīhā [year 649/1251-2] faragha ismā' $\bar{\imath}$ al-Ta'rìkh wa-al-Rawdatayn'.

22 Abū Shāma, Rawḍatayn, I, 30: 'wa-aradtu an yafhama al-kalām al-khāṣs wa-al-'āmm'. 
23 The manuscripts Copenhagen 554 (copied 676/1278), Bodleian, Marsh 383 (copied 678/1279-80) and Cairo Dār al-kutub 108 (vol. 2) (copied 1123/1711) refer to him. The early thirteenth-/nineteenth-century printed editions of the Rawdatayn by The Syrian Press in Beirut and the $W \bar{a} d \bar{\imath}$ al-Nìl press in Cairo were also based on these manuscripts.

24 The following manuscripts are based on this line of transmission: Cairo, Dār al-kutub 108 (vol. 1) (copied 734/1333), Leiden Cod. 77 (copied 733/1333), Bankipore no. 1065 (copied 1278/1861).

25 On the Banū Șaṣrāa and Najm al-Dīn in particular: Brinner (1960); Brinner, W.M. in: EI2 'Ibn Sastrā' and Pouzet (1991), 43.

26 On the manuscripts of the 'Uȳun, see the editor's introduction to Abū Shāma, 'Uyūn, I, 143 and 160. The third manuscript was copied by an anonymous scribe in 972/1565.

27 Abū Shāma, Rawḍatayn, Paris BN, arabe 1701, with the title Kitāb riyād al-jannatayn f $\bar{\imath}$ akbbār al-dawlatayn (de Slane (1883-95), 316).

28 Official responsible for writing memoranda. At a later date this official became responsible for presenting matters, which required decisions in the imperial dīwān meetings (Findley (1980), 51-2).

29 Abū Shāma, Rawḍatayn, Bodleian, Bruce 63, fols. 1a and 429a: 'kātib al-aḅkām al-Hūmāyūñ̄ya bi-al-abwāb al-sulțāñ̄ya wa-al-tadbkiriji bi-diwān Miṣr'.

30 Bankipore: Nadwi (1929), XV, p. 146, no. 1065.

31 On it, see Fleischer (1858); Fleischer (1885-8), III, 109-27; Ayalon (1995), esp. 31-4; Glass (2001), 37-42.

32 For the similar focus on 'modernization' in the early Persian press, see Pistor-Hatam (1999), 345-70.

33 Hadīqat al-akhbār, Numbers 2, 15, 19 and 21.

34 Hadīqat al-akhbār, Number 27.

35 Ḥadīqat al-akhbār, Numbers 28, 29, 32, 34, 36, 37, 39, 40, 41, 43, 46, 49, 51, 72, 87, and 89.

36 To my knowledge the print never materialized, and this advertisement in 1860 must have been premature. The first complete edition of the Rawdatayn was the Egyptian Wād $\bar{\imath}$ al-Nìl print in 1871.

37 Advertised in Hadīqat al-akhbār, Number 124 (17 May 1860): Khalīl al-Khūrī: Zahr al-rabā fī shi'r al-șabā; Riwāyat al-Mārkīz de Fontange; al-Qawānīn al-tijārāya; Ibrāhīm Bey: Mádan al-ifāda fì al-babal wa-al-wiläda; Ibrāhīm Bey: Miṣbāh al-sārì; Salīm Bustrus (d. 1300/1883): al-Nuzha al-shahìya fì al-riḅla al-Salīmīya.

38 Hourani (1983), 67.

39 Way, idhan lastu bi-Ifranjī. On it, see Wielandt (1980), 130-6.

40 Ayalon (1995), 41.

41 On the interpretations of this period in modern Arab scholarship, see Sivan (1985), Hillenbrand (1999), 589-616 and Brett (2001).

42 'Āṣī (1991), esp. 8.

43 Mūsā (1999) who summarizes the Rawdatayn in his own words (more or less) as he considers Abū Shāma's own summary, 'Uȳunn, to be inadequate for a modern audience. On the Rawdatayn as an anti-Crusader work, see especially the prefaces by the different individuals involved: pp. 4, 7-8 and 11 .

44 Abū Shāma, 'Uyūn, for example, I, 138.

45 Mūsā (1999), 8.

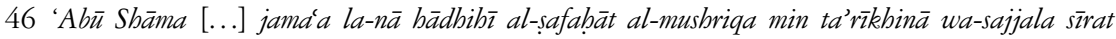
bādhayn al-hākimayn al-mu'minayn (Nūr al-Dīn Zankī wa-Salāh al-Dīn al-Ayyūbī) li-takūna 'iza mamdūda wa-'ibra ma'rūda li-man arāda li-nafsibi wa-ummatibi khayr al-dunyā wa-al-ākbira'.

\section{CONCLUSION}

1 Robinson (2003), 188. 


\section{BIBLIOGRAPHY}

References to 'EI2' in the footnotes refer to the Encyclopaedia of Islam, 2nd edition, Leiden 1960-2003. References to 'EI2 (CD-Rom version)' to the CD-Rom version, Leiden 2002 (Letters A to U). 'BL' refers to British Library. In the entries' order no account is taken of the letters 'ayn and 'hamza, the definite article al-lel-and diacritical marks.

\section{Primary sources}

Abū al-Fidā’, Ismā̄îl b. 'Alī (d. 732/1331) al-Mukbtașar fī akhbār al-bashar, 4 vols (ed. n.n.), Cairo 1907.

Abū Shāma, 'Abd al-Rahmān b. Ismāềl (d. 665/1267) al-Bā'ith 'alā inkār al-bidāc wa-al-hawādith (ed. 'U.A. 'Anbar), Cairo 1978. (Further editions: (ed. M.F. al-Ṭarābulusī), Cairo 1955 and (ed. H. Salmān), Riyad 1990).

-Daw' [al-qamar] al-sārī ilā ma'rifat ru'yat al-bārī (ed. A. al-Sharīif), Cairo 1985 [Alternative title: Daw' al-qamar al-sārī ilà márifat al-bārī].

_al-Dhayl 'alā al-Rawdatayn (published as: Taräjim rijāl al-qarnayn al-sādis wa-al-sābic) (ed. Muhammad al-Kawtharī), Cairo 1947. (Based on manuscript Istanbul, Köprülü 1080.) Additional manuscripts consulted: Berlin Spr. 53 (Ahlwardt catalogue 9813); Berlin Mf 78 (Ahlwardt catalogue 9814); BL or. 1538 (part 1); BL or. 1539 (part 2).

Ibrāz al-ma'ān̄̄ min hirz al-amān̄i fì al-qira'āt al-sab' (ed. I.'A. 'Awāḍ), Cairo 1982. Additional manuscripts consulted: BL Add 27507; Berlin Spr. 385 (Ahlwardt catalogue 606).

Kitāb al-rawdatayn fì akbbār al-dawlatayn al-Nürīya wa-al-Saläbīya, 5 vols (ed. Ibrāhīm al-Zỉbaq), Beirut 1997. Additional manuscripts consulted: Berlin WE 127 (Ahlwardt catalogue 9812); BL Add 7312; BL or. 24015; Bodleian, Clarke 7; Bodleian, Bruce 63; Bodleian, Marsh 383. Additional editions consulted: 2 vols (ed. n.n.) Cairo 1871 (Wādī al-Nīl) and 2 vols (ed. M.H.M. Ahmad) Cairo 1956 (vol. 1, p. 1), 1962 (vol. 1, p. 2), 1998 (vol. 2, p. 1), last part not published yet.

_al-Mubaqqaq min 'ilm al-ușül fì mā yata'allaqu bi-af'āl al-Rasūl (ed. A. al-Kuwaytī), al-Haram (Cairo) 1990 (reprint of first edition 1988).

_al-Mujallada al-khāmisa 'ashar min sharh Tảrīkh Dimashq, Berlin WE 16 (Ahlwardt catalogue 9782).

-Mukbtasar al-mu'ammal fí al-radd ilā al-amr al-awwal (ed. Ș.M. Aḥmad), Kuwait no date (1983?).

- al-Murshid al-waj̄̄z ilā' 'ulūm tata'allaqu bi-al-kitāb al-'azīz, see Altıkulaç (1975). 
Abū Shāma, 'Abd al-Raḥmān b. Ismā̄īl (d. 665/1267) Qaṣīda, in: al-Durr al-fäkhir fī sharh 'uqūd al-jawāhir wa-murshid al-sāmi' wa-al-mutakallim ilā adab al-'ālim wa-al-mutáallim, (anonymous writer), Berlin Mq 65, fols 85b-88a (Ahlwardt catalogue 103 and 7772).

'Uȳ̄n al-rawdatayn, 2 vols (ed. Aḥmad al-Baysūmī), Damascus 1991-2.

al-Āmidī, 'Alī b. Muhammad (d. 631/1233) Kitāb al-iḅkām fì usūul al-abkām, 4 vols in 2 (ed. Sayyid al-Jumaylī), Beirut 1984. (See Weiss (1992) for paraphrase.)

al-Asnawī, 'Abd al-Rahīm b. al-Hasan (d. 772/1370) Ṭabaqāt al-Shāfi'ìya, 2 vols (ed. 'Abd Allāh Jibūrī), Baghdad 1970-1.

al-'Ayn̄̄, Maḥmūd b. Aḥmad (d. 855/1451) 'Iqd al-jumān fī tàrīkh abl al-zamān (ed. M. Muhammad Amīn), Cairo 1987-(not completed).

Bahā' al-Dīn, Zuhayr b. Muhammad (d. 656/1258) Dīwān (ed. n.n.), Beirut 1964.

al-Bundārī, al-Fatḥ b. 'Alī (d. 643/1245) Sanā al-Barq al-Shāmī (ed. R. Şeşen), Beirut 1971.

Calabī al-Rūmīe Mūsā b. Muhammad (d. 931/1525) Sharh tashkīl al-tàsīs li-Muhammad b. Ashraf al-Husayn̄̄ al-Samarqand̄̄ (ed. M. Suwaysī), Tunis 1984.

al-Dhahabī, Muhammad b. Ahmad (d. 748/1348) Márifat al-qurrā' al-kibār 'alā al-țabaqāt wa-al-a'șār, 2 vols (eds B. 'Awwād Ma'rūf/Shu'ayb al-Arnāūūt), Beirut 1984 (reprint of edition Cairo 1967).

Siyar al-âlām al-nubalā', 25 vols (eds Shu'ayb al-Arnāūṭ et al.), Beirut 1981-8.

- Tadbkirat al-buffäz, 4 vols (ed. n.n.), Haydarabad 1915-16.

—Ta'rīkh al-Islām wa-wafayāt al-mashāhīr wa-al-âlām, 52 vols (ed. 'U.'Abd al-Salām Tadmurī), Beirut 1987-2000.

al-Fārābī, Muhammad b. Muhammad (d. 339/950) Iḅsă’’ al-'ulūm (ed. 'U. Amīn), Cairo 1948.

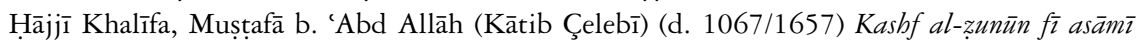
al-kutub wa-al-funūn, 2 vols (eds Ş. Yaltkaya/K.R. Bilge), Istanbul 1941-3.

Ibn 'Abd al-Z̄āhir, 'Abd Allāh (d. 692/1292) al-Rawd al-zāhir fī sīrat al-Malik al-Zāahir (ed. 'Abd al-'Azīz al-Khuwayțir), Riyad 1976.

Ibn Abī al-Damm, Ibrāhīm b. 'Abd Allāh (d. 642/1244) Kitāb al-shamārīkh fĩ al-tàrīkh (partly edited (years 617-26) by Richards (1993a)).

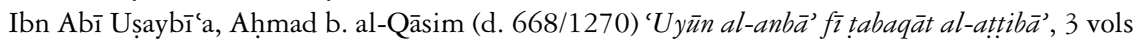
(ed. n.n.), Beirut 1979.

Ibn al-'Adīm, 'Umar b. Ahmad (d. 660/1262) Zubdat al-halab min ta'rīkh Halab, 3 vols (ed. S. Dahhān), Damascus 1951-68.

Ibn al-Akfānī, Muhammad b. Ibrāhīm (d. 749/1348) Kitāab irshāed al-qāṣid ilā asnā al-maqūṣid (ed. J.J. Witkam), Leiden 1989.

Ibn al-Athīr, 'Alī b. Muhammad (d. 630/1233) al-Kāmil fī al-tárīkh, 13 vols (ed. C.J. Tornberg), Beirut 1965-7 (reprint of 1851-71 edition with corrections and new pagination).

- al-Lubāb fì tahdhīb al-ansāb, 3 vols (ed. n.n.), Cairo 1938-49.

_ al-Tàrīkh al-bāhir fì al-dawla al-atābakìya (ed. 'A.A. Țulaymāt), Cairo 1963.

Ibn al-Furāt, Muhammad b. 'Abd al-Rahīm (d. 807/1405) Tảrīkh al-duwal wa-al-mulūk, vols 7-9 (eds C.K. Zurayk/N. Izzedin), Beirut 1939-47.

Ibn Hanbal, Aḥmad b. Muhammad (d. 241/855) al-Musnad, 8 vols (eds M. Samāra/ 'A. al-Ṭawīl/S. Ghāwī), Beirut 1993.

Ibn Jamāca, Muhammad b. Ibrāhīm (d. 733/1333) Tạ̣rīr al-ạ̣kām fī tadbīr ahl al-islām (ed. and tr. H. Kofler), Islamica VI (1934): 349-414; VII (1935): 1-64; Schlußheft (1938): $18-129$.

Ibn al-Jawzī 'Abd al-Rahmān b. 'Alī (d. 597/1200) al-Muntažam fì tawārìkh al-mulūk wa-al-umam, 13 vols (ed. Suhayl Zakkār), Beirut 1995-6. 
Ibn al-Jazarīi, Muhammad b. Muḥammad (d. 833/1429) Ghāyat al-nihāya fī tabaqāt al-qurrāà, 2 vols (eds Gotthelf Bergsträsser/Otto Pretzl), Cairo 1933-5.

-Munjid al-muqri'ìn wa-murshid al-țālibīn (ed. 'A.b.M. al-'Imrān), Mecca 1998-9.

Ibn Jubayr, Muhammad b. Ahmad (d. 614/1217) al-Ribla (ed. W. Wright, Second edition. revised by M.J. de Goeje), Leiden/London 1907. (See Broadhurst (1952) for translation.)

Ibn Kathīr, Ismā̄îl b. 'Umar (d. 774/1373) al-Bidāya wa-al-nihāya fī al-tàrīkh, 15 vols (eds 'Alī N. Ațwī et al.), Beirut 1985.

Ibn Khaldūn, 'Abd al-Rahmān b. Muhammad (d. 808/1406) al-Muqaddima, 2 vols (ed. 'A. Wāfí), Cairo 1958. (See Rosenthal (1967) for translation.)

Ibn Khallikān, Ahmad b. Muḥammad (d. 681/1282) Wafayāt al-a'yān wa-abnāa' al-zamān, 8 vols (ed. Ihsān 'Abbās), Beirut 1968-72. Additional manuscript consulted: BL Add. 25735.

Ibn Manẓūr, Muhammad (d. 711/1311) Lisān al-'arab, 15 vols (ed. n.n.), Beirut 1955.

Ibn al-Mughayzil, 'Alī b. 'Abd al-Rahīm (d. 701/1302): Dhayl mufarrij al-kurūb fì akbbār ban̄̄ Ayyūb (ed. 'U. Tadmurī), Beirut 2004. Additional manuscripts consulted: Paris, Bibliothèque Nationale, MS arabe 1702 and 1703.

Ibn al-Naz̄iff, Muhammad b. 'Alī (d. after 634/1236-7) al-Ta’rīkh al-Manșūrī (ed. B. Doudou), Damascus 1981.

Ibn Qāạ̄i Shuhba, Abū Bakr b. Aḥmad (d. 851/1448) Ṭabaqāt al-Shāfi'īya, 4 vols (ed. 'Abd al-'Alīm Khān), Beirut 1987.

Ibn al-Ṣābūnī, Muhammad b. 'Alī (d. 680/1282) Takmilat ikmāl al-ikmāl (ed. n.n.), Beirut 1986.

Ibn Shaddād, Muhammad b. 'Alī (d. 684/1285) al-A'lāq al-khațīra fī dhikr umarā' al-Shām wa-al-Jazīra (ed. D. Sourdel), Damascus 1953.

Ibn Shaddād, Yūsuf b. Rāfi' (d. 632/1234) al-Nawādir al-sulțāñ̄ya wa-al-mahāsin al-Yū̄sufīya (ed. J. al-Shayyāl), Cairo 1964. (See Richards (2001) for translation.)

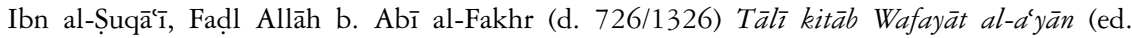
Jacqueline Sublet), Damascus 1974.

Ibn Taghrībirdī, Yūsuf (d. 874/1470) al-Manhal al-șâfī wa-al-mustawfī ba'da al-wāfī (eds M. Muḥammad Amīn/Nabīl M. 'Abd al-'Azīz), Cairo 1984-(not completed).

_al-Nujūm al-zāhira fī mulūk Miṣr wa-al-Qāhira, 16 vols (eds Fahīm M. Shaltūt et al.), Cairo 1929-72.

Ibn Taymīya, Aḥmad b. 'Abd al-Ḥalīm (d. 728/1328) Jahd al-qāhira fī tajrīd al-nașīha (translation of al-Suyūțî’'s abridgement: W.B. Hallaq (1993): Ibn Taymīya against the Greek Logicians, Oxford).

Ibn Tuwayr, 'Abd al-Salām b. al-Hasan (d. 617/1220) Nuzhat al-muqlatayn fī akhbār al-dawlatayn (ed. A. Fu'ād Sayyid), Beirut 1992.

Ibn Wāṣil, Muhammad b. Sālim (d. 697/1298) Mufarrij al-kurūb fì akbbār banī Ayyū̄, 5 vols (eds J. al-Shayyāi/H. al-Rabī'/S. 'Āshūr), Cairo 1953-(final 6th volume (years 646-59) not published yet). Additional manuscripts consulted: Paris, Bibliothèque Nationale, MS arabe 1702 and 1703; Cambridge, University Library, Ll.1.6 (Browne Catalogue no. 1079).

— Nażm al-durar fì al-hawādith wa-al-siyar, Chester Beatty Library, Ms. Ar. 5264.

- Nukbbat al-fikar fì tathqīf al-nazar, Yale University, Reinecke Rare Book and Manuscript Library, no. 1406. (In some primary sources referred to as Nukbbat al-fikar fí al-mantiq.)

— Tajrìd al-Aghān̄̄, 2 vols (eds Ṭāhā Husayn/Ibrāhīm Abyārī), Cairo 1955. Additional manuscript consulted: BL Add 7339 (Kitāb mukhtasar al-Aghānī).

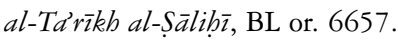

'Imād al-Dīn al-Iṣfahān̄i, Muhammad b. Muhammad (d. 597/1201) al-Barq al-Shāmī, vol. 5 (years 578-9) (ed. Fātiḥ Husayn), Amman 1987. 
'Imād al-Dīn al-Iṣfahānī, Muhammad b. Muhammad (d. 597/1201) al-Fatḥ al-Qussī fī al-fath al-Qudsī (ed. C. de Landberg), Leiden 1888. (See Massé (1972) for translation.)

al-Kutubī, Muhammad b. Shākir (d. 764/1363) Fawāt al-wafayāt wa-al-dhayl 'alayhā, 5 vols (ed. Iḥsān 'Abbās), Beirut 1973-4.

'Uyūn al-tawārīkh, vol. 20 (eds Fayṣal al-Sāmir/'Abd al-Mun'im Dāūu), Baghdad 1980.

al-Maqrīzīi Ahmad b. 'Alī (d. 845/1442) al-Mawā'iz wa-al-i'tibār fì dhikr al-kbitạt wa-al-äthār, 3 vols (eds Muhammad Zaynhum/Madīha al-Sharqāwī), Cairo 1997.

al-Mas'ūdī, 'Alī b. al-Husayn (d. 345/956) Murūj al-dhahab wa-ma'ädin al-jawhar, 7 vols (ed. C. Pellat), Beirut 1965-79.

al-Nasawī, Muhammad b. Aḥmad (d. 647/1249-50) Sìrat al-Sulțān Jalāl al-Dīn Mankübirtī (ed. H.A. Hamdī), Cairo 1953. (See Houdas (1895) for translation.)

al-Nu'aymīi, 'Abd al-Qādir b. Muhammad (d. 927/1521) al-Dāris fī tà rìkh al-madāris, 2 vols (ed. Ja'far al-Hasan̄i), Damascus 1948-51.

al-Rāzī, Muhammad b. 'Umar (d. 606/1210) Kitāb al-arba'īn fī usūl al-dīn (ed. n.n.), Haydarabad 1934.

al-Ṣafadī, Khalīl b. Aybak (d. 764/1363) A'yān al-aṣr wa-a'wān al-nașr, 4 vols (ed. F. Ahmad al-Bakkūr), Beirut 1998.

—al-Wāf $\bar{\imath}$ bi-al-wafayāt, 29 vols (eds Hellmut Ritter et al.), Istanbul and others 1931-97.

al-Sakhāwī, Muḥammad b. 'Abd al-Raḥmān (d. 902/1497) al-I'lān bi-al-tawbīkh li-man dhamma abl al-ta’rīkh (tr. and ed. S..A. al-'Alī), Baghdad 1963.

al-Sam'ān̄̄, 'Abd al-Karīm b. Muhammad (d. 562/1166) Kitāb al-ansāb, 13 vols (eds al-Mu'allimī et al.), Haydarabad 1952-82.

al-Sanūsī, Muḥammad b. 'Alī (d. 1276/1859) Īqāz al-wasnān fī al-'amal bi-al-ḥadīth wa-alQur'ān, in: al-Majmū' a al-mukbtāra (ed. n.n.), Manchester 1990: 11-141.

Shāh Walī Allāh, Aḥmad b. 'Abd al-Rahīm (d. 1180/1766) al-Inșāf fī bayān sabab al-ikhtilāf fī al-abkām al-fiqhīya (ed. M. al-Khațīb), Cairo 1965-6.

'Iqd al-jìd fì abkām al-ijtihād wa-al-taqlīd (tr. Rahbar, M.D., in: The Muslim World 45 (1955): 346-58).

al-Shawkānī, Muhammad b. 'Alī (d. 1250/1834) Irshād al-fubūl ilā tahqūq al-haqq min 'ilm al-usūul (ed. n.n.), Cairo 1937.

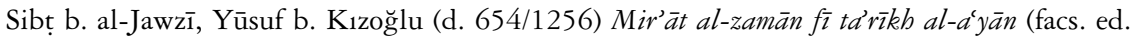
R.R. Jewett), Chicago 1907.

Mir'āt al-zamān fì ta'rīkh al-a'yān, vol. 8 (ed. n.n.), Haydarabad 1951-2.

al-Subkī, 'Abd al-Wahhāb b. 'Alī (d. 771/1370) Țabaqāt al-Shāfi'ìya al-kubrāa, 10 vols (eds M. Muhammad al-Ṭanāh̄i/‘Abd al-Fattāh M. al-Hilw), Cairo 1964-76.

al-Subkī, 'Alī b. 'Abd al-Kāfī (d. 756/1355) Fatāwā al-Subkī, 2 vols (ed. n.n.), Cairo 1936-7.

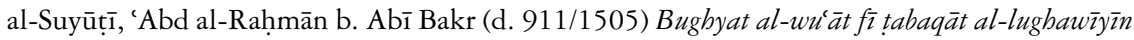
wa-al-nuhāt, 2 vols (ed. M. Abū al-Faḍl Ibrāhīm), Cairo 1964-5.

—al-Taḅadduth bi-ni'mat Allāh (ed. E.M. Sartain), Cambridge 1975.

al-Tabarī, Muhammad b. Jarīr (d. 310/923) The History of al-Ṭabarī, vol. 17: The First Civil War (annotated translation by G. Hawting), Albany (NY) 1996; vol. 26: The Community Divided (annotated translation by A. Brockett), Albany (NY) 1997; vol. 34: Incipient Decline (annotated translation by J.L. Kraemer), Albany (NY) 1989.

-Ta'rīkh al-rusul wa-al-mulūk wa-man kāna fì zamān min kull minhum, 13 vols (ed. Jamīl al-'Aț̣ār), Beirut 1998.

al-Yāfi'ī, 'Abd Allāh b. As'ad (d. 768/1367) Mir'āt al-janān wa-'ibrat al-yaqzāan, 4 vols (ed. n.n.), Haydarabad 1919-21. 
Yāqūt b. 'Abd Allāh al-Ḥamawī (d. 626/1229) Mu'jam al-udabbā', 7 vols (ed. Iḥsān 'Abbās), Beirut 1993.

al-Yūnīnī, Mūsā b. Muhammad (d. 726/1326) Dhayl mir'āt al-zamān, 4 vols (ed. n.n.) Haydarabad 1954-61 (years 654/1256-686/1288) and Guo, L. (1998) Early Mamluk Syrian Historiography. Al-Yūnīn'̄'s Dhayl mir'āt al-zamān, Leiden/Boston/Köln (years 697/1297-701/1302).

\section{Secondary sources}

Abrahamov, B. (1998) Islamic Theology. Traditionalism and Rationalism, Edinburgh.

Ahlwardt, W. (1897) Verzeichniss der arabischen Handschriften der Königlichen Bibliothek zu Berlin, Berlin.

Ahmad, M.H.M. (1951) 'Studies on the Works of Abū Shāma 599-665 AH (1203-1267)', unpublished $\mathrm{PhD}$ Thesis, University of London.

(1956) 'Dirāsa wa-tahlīil', in M.H.M. Ahmad (ed.) Ab̄u Shāma: Kitāb al-rawdatayn fī akbbār al-dawlatayn al-Nūrīya wa-al-Șalāhàya, vol. 1, p. 1, Cairo: 1-57.

- (1962) 'Some Notes on Arabic Historiography during the Zengid and Ayyubid Periods (521/1127-648/1250)', in B. Lewis and P.M. Holt (eds) Historians of the Middle East, London: 79-97.

Ali-Karamali, S.P. and Dunne, F. (1994) 'The ijtihad Controversy', Arab Law Quarterly 9: 238-57.

Altıkulaç, T. (1975) Ebū Shāme el-Makdisî ve el-Murşid el-Vecîz, Beirut.

Ambros, A. (1990) 'Beobachtungen zu Aufbau und Funktion des gereimten klassisch-arabischen Buchtitels', Wiener Zeitschrift für die Kunde des Morgenlandes 80: 13-57.

Amīn, M.M. (1981) Fibrist wathā'iq al-Qāhira hattā nihāyat 'aṣr al-mamālīk (239/853-922/ 1516), Paris.

Arberry, A.J. (1955-66) The Chester Beatty Library. A Handlist of Arabic Manuscripts, Dublin.

Arjomand, S.A. (1999) 'Islamic Institutions of Learning - the Law, Agency, and Policy in Medieval Islamic Society: Development of the Institutions of Learning from the Tenth to the Fifteenth Century', Comparative Studies in Society and History 41: 263-93.

Ashtor, E. (1969) Histoire des prix et des salaires dans l'Orient médiéval, Paris.

(1971) 'Salaires dans l'Orient médiévale à la basse-époque', Revue des Etudes Islamiques 39: 103-117.

'Āṣī, H. (1991) al-Mu'arrikh Abū Shāma wa-kitābubu al-Rawdatayan fī akbbār al-dawlatayn al-Nürīya wa-al-Șalābìya, Beirut.

Assmann, J. (1992) Das kulturelle Gedächtnis. Schrift, Erinnerung und politische Identität in frïhen Hochkulturen, München.

Auerbach, E. (1953) Mimesis. The Representation of Reality in Western Literature, Princeton. (German edition 1946).

Ayalon, A. (1995) The Press in the Arab Middle East: A History, New York and Oxford. al-Azmeh, A. (1983) al-Kitāba al-ta'rīkhīya wa-al-márifa al-tàrīkhīya, Beirut.

- (1984) 'L'annalistique entre l'histoire et le pouvoir: une conception de l'histoire sousjacente aux chroniques, biographies et gestes dans l'aire culturelle arabo-islamique', in UNESCO (ed.) Histoire et Diversité des Cultures, Paris: 95-116.

- (1986a) Arabic Thought and Islamic Societies, London, Sydney and Dover (NH).

_- (1986b) 'Histoire et narration dans l'historiographie arabe', Annales 41: 411-31.

(1997) Muslim Kingship. Power and the Sacred in Muslim, Christian, and Pagan Polities, London and New York. 
al-Azmeh, A. (1998) 'Muslim History: Reflections on Periodisation and Categorisation', The Medieval History Journal 1: 195-231.

al-'Azzāwīi, 'A. (1957) al-Tárīf bi-al-mu'arrikhīn, vol. 1: Fī' 'abd al-Mughül wa-al-Turkmān, Baghdad.

Bakar, O. (1998) Classification of Knowledge in Islam. A Study in Islamic Philosophies of Science, Cambridge.

Barrucand, M. (1988) 'Gärten und gestaltete Landschaft als irdisches Paradies: Gärten im westlichen Islam', Der Islam 65: 244-67.

el-Beheiry, S. (1974) 'Le décret de nomination de l'historien Ibn Wāṣil au poste de professeur de la mosqueé al-Aqmar', Annales Islamologiques 12: 85-94.

Berkey, J. (1992) The Transmission of Knowledge in Medieval Cairo. A Social History of Islamic Education, Princeton (NJ).

(1995) 'Tradition, Innovation and the Social Construction of Knowledge in the Medieval Islamic Near East', Past and Present 146: 38-65.

Bierman, I.A. (1998) Writing Signs. The Fatimid Public Text, Berkeley (CA), Los Angeles (CA) and London.

Black, A. (2001) The History of Islamic Political Thought. From the Prophet to the Present, Edinburgh.

Blacker, J. (1994) The Faces of Time: Portrayal of the Past in Old French and Latin Historical Narratives of the Anglo-Norman Regnum, Austin (TX).

Brett, M. (2001) 'Islamic Historiography of the Crusades, 1951-2001', paper presented at Third International Conference: Half a Century of Studies on Crusades and Military Orders 1951-2001, Teruel and Spain, 19-25 July 2001.

Brinner, W.M. (1960) 'The Banū Ṣaṣrā: A Study in the Transmission of a Scholarly Tradition', Arabica 7: 167-95.

Broadhurst, R.J.C. (tr.) (1952) The Travels of Ibn Jubayr, London (tr. of Ibn Jubayr's al-Ribla).

Brockelmann, C. (1949) Geschichte der arabischen Litteratur, supplement vols I-III, Leiden 1937-42, revised edition of vols I and II 1943-9.

Browne, E.G. (1900) A Hand-List of the Muhammadan Manuscripts Including All Those Written in the Arabic Characters Preserved in the Library of the University of Cambridge, Cambridge.

Cahen, C. (1940) La Syrie du nord à l'époque des Croisades, Paris.

_- (1986) 'Sur le Tārīkh Șāliḥ̄i d'Ibn Wāṣil: notes et extraits', in M. Sharon (ed.) Studies in Islamic History and Civilization in Honour of Professor David Ayalon, Jerusalem and Leiden: 501-16.

Calder, N. (1996) 'al-Nawawī's Typology of muftīs and its Significance for a General Theory of Islamic Law', Islamic Law and Society 3: 137-64.

Carmona, A. (2000) 'Sobre la estructura convencional del título en los libros árabes', al-Qantara: revista de estudios árabes 21: 85-95.

Chamberlain, M. (1994) Knowledge and Social Practice in Medieval Damascus, 1190-1350, Cambridge.

Chapoutot-Remadi, R. (1993) 'Liens et relations au sein de l'élite Mamluke sous les premiers Sultans Bahrides 648/1250-741/1340', 2 vols unpublished PhD Thesis, University of Provence, Aix Marseille I.

Conermann, S. (1998) 'Einige allgemeine Überlegungen zum vormodernen "Historischen Denken" der Araber', Orientalische Literaturzeitung 93: 141-57.

Cook, M. (2000) Commanding Right and Forbidding Wrong in Islamic Thought, Cambridge.

Corbin, H. (1962) 'De la philosophie prophéthique en Islam Shi'ite', Eranos Jabrbuch 31: 49-116. 
(1966) 'The Visionary Dream in Islamic Spirituality', in G.E. von Grunebaum and R. Caillois (eds) The Dream and Human Societies, Berkeley (CA) and Los Angeles (CA): 381-401. Daftary, F. (1994) The Assassin Legends. Myths of the Ismā'inlis, London and New York.

Daiber, H. (1985) 'Die Kreuzzüge im Licht islamischer Theologie. Theologische Interpretamente bei Abū Shāma', in A. Zimmermann and I. Craemer-Ruegensberg (eds) Orientalische Kultur und europäisches Mittelalter, Berlin and New York: 77-85.

Daniel, U. (1997) 'Clio unter Kulturschock. Zu den aktuellen Debatten der Geschichtswissenschaft', Geschichte in Wissenschaft und Unterricht 48: 195-218 and 259-78.

Darnton, R. (1984) The Great Cat Massacre and Other Episodes in French Cultural History, London.

Davis, N.Z. (1983) The Return of Martin Guerre, Cambridge (MA).

Della Vida, G.L. (1935) Elenco dei manoscritti arabi islamici della Biblioteca Vaticana, Vatican.

Derenbourg, H. (1884-1928) Les manuscrits arabes de l'Escurial, 3 vols, Paris.

Donner, F.M. (1998) Narratives of Islamic Origins: The Beginnings of Islamic Historical Writing, Princeton (NJ).

Doudou, B. (1981) 'Introduction', in Ibn al-Nazîif, Muhammad b. 'Alī (d. after 634/1236-7): al-Ta'rīkh al-Mansūurì (ed. B. Doudou), Damascus.

Eddé, A.-M. (1999) La principauté Ayyoubide d'Alep (579/1183-658/1260), Stuttgart.

Ehrenkreutz, A.S. (1972) Saladin, Albany (NY).

Elisséeff, N. (1967) Nür al-Dīn. Un grand prince musulman de Syrie au temps des Croisades (511-569/1118-1174), 3 vols, Damascus.

Emirbayer, M. and Goodwin, J. (1994) 'Network Analysis, Culture, and the Problem of Agency', American Journal of Sociology 99 (11): 1411-54.

Ephrat, D. (2000) A Learned Society in a Period of Transition: The Sunni 'Ulamā' of Eleventh-Century Baghdad, Albany (NY).

Ernst, H. (1960) Die mamlukischen Sultansurkunden des Sinai Klosters, Wiesbaden.

Escovitz, J.H. (1984) The Office of Qād̄̄ al-Qudāt in Cairo under the Baḅrī Mamlūks, Berlin.

Evans, R.J. (1997) In Defence of History, London.

Fadel, M. (1996) 'The Social Logic of taqlìd and the Rise of the Mukbtasar', Islamic Law and Society 3: 193-233.

Fagnan, E. (1893) Catalogue générale des manuscrits des bibliothèques publiques de France: départements - Alger (vol. 18), Paris.

Fahd, T. (1966) La divination A rabe. Etudes religieuses, sociologiques et folkloriques sue le milieu natif de l'Islam, Paris.

Fähndrich, H. (1973) 'The wafayāt al-a'yān of Ibn Khallikān: A New Approach', Journal of the American Oriental Society 93: 432-45.

(1977) 'Compromising the Caliph. Analysis of Several Versions of an Anecdote About Abū Dulāma and al-Manșūr', Journal of Arabic Literature 8: 36-47.

Farah, C.E. (1967) The Dhayl in Medieval Arabic Historiography, New Haven (CT).

Fierro, M. (1992) 'The Treatises Against Innovations (Kutub al-bida')', Der Islam 69: 204-46.

Findley, C.V. (1980) Bureaucratic Reform in the Ottoman Empire: The Sublime Porte, 1789-1922, Princeton (NJ).

Fleischer, H.L. (1858) 'Hadīkat al-akhbār, eine neue arabische Zeitung', Zeitschrift der Deutschen Morgenländischen Gesellschaft 12: 330-3.

- (1885-8) Kleinere Schriften, 3 vols, Leipzig.

Franz, K. (2004) Kompilation in arabischen Chroniken. Die Überlieferung vom Aufstand der Zanğ zwischen Geschichtlichkeit und Intertextualität vom 9. bis ins 15. Jabrbundert, Berlin and New York. 
Freimark, P. (1967) 'Das Vorwort als literarische Form in der arabischen Literatur', unpublished PhD Thesis, University of Münster.

Friedmann, Y. (1989) Prophecy Continuous. Aspects of Abmad̄̄ Religious Thought and its Medieval Background, Berkeley (CA), Los Angeles (CA) and London.

Frye, N. (1967) Anatomy of Criticism: Four Essays, New York.

- (1981) The Great Code. The Bible and Literature, New York and London.

Gabrieli, F. (1956) 'Le ambascerie di Baibars a Manfredi', in Studi Medievali in onore di Antonino de Stefano, Palermo: 219-25.

Garcin, J.-C. (1967) 'Histoire, opposition, politique et piétisme tradionaliste dans le Husn Al Muhāāarat de Suyûti', Annales Islamologiques 7: 33-88.

_ (1969) 'Le Caire et la province: constructions au Caire et à Qûs sous les Mameluks Bahrides', Annales Islamologiques 8: 47-62.

Geertz, C. (1973) 'Thick Description: Toward an Interpretive Theory of Culture', in C. Geertz The Interpretation of Cultures, New York: 3-30.

Gerber, H. (1999) Islamic Law and Culture, 1600-1840, Leiden, Boston (MA) and Köln.

al-Ghamdi, S. (1989) 'Autobiography in Classical Arabic Literature: An Ignored Literary Genre', unpublished PhD Thesis, University of Indiana.

Gibb, H.A.R. (1950) 'The Arabic Sources for the Life of Saladin', Speculum 25: 58-72.

Gilbert, J.E. (1977) 'The Ulama of Medieval Damascus and the International World of Islamic Scholarship', unpublished PhD Thesis, University of California, Berkeley.

Glass, D. (2001) 'Von Mir'āt al-abwāl zu Thamarāt al-funūn: Anfänge der freien arabischen Presse im osmanischen Syrien', in A. Pistor-Hatam (ed.) Amtsblatt, vilayet gazetesi und unabbängiges Journal: die Anfänge der Presse im Naben Osten, Frankfurt (Main): 29-45.

Gleba, G. (ed.) (2000) Instrumentalisierung von Historiographie im Mittelalter, Berlin.

Goertz, H.-J. (2001) Unsichere Geschichte. Zur Theorie historischer Referentialität, Stuttgart.

Goetz, H.-W. (1992) 'Die Gegenwart der Vergangenheit im früh- und hochmittelalterlichen Geschichtsbewußtsein', Historische Zeitschrift 255: 61-97.

Goldziher, J. (1895/1969) 'Historiography in Arabic Literature', in J. Goldziher Gesammelte Schriften J. Desomogyi (ed.) 6 vols, Hildesheim 1967-73: vol. 3, 359-94 (orig. 1895, tr. J. Desomogyi).

(1916/1970) 'Stellung der alten islamischen Orthodoxie zu den antiken Wissenschaften', in J. Goldziher Gesammelte Schriften J. Desomogyi (ed.) 6 vols, Hildesheim 1967-73: vol. 5, 357-400.

Gottschalk, H.L. (1958) al-Malik al-Kāmil von Egypten und seine Zeit, Wiesbaden.

Grunebaum, G.E. von (1966) 'Introduction: The Cultural Function of the Dream as Illustrated by Classical Islam', in G.E. von Grunebaum and R. Caillois (eds) The Dream and Human Societies, Berkeley and Los Angeles: 3-21.

Haarmann, U. (1991) 'Der arabische Osten im späten Mittelalter 1250-1517', in U. Haarmann (ed.) Geschichte der arabischen Welt, München: 217-63.

- (1996) 'Medieval Muslim Perceptions of Pharaonic Egypt', in A. Loprieno (ed.) Ancient Egyptian Literature. History and Forms, Leiden, New York and Köln: 605-27.

_- (2001) 'al-Maqrīì̄i, the Master and Abū Hāmid al-Qudsī, the Disciple - Whose Historical Writing Can Claim More Topicality and Modernity', in H. Kennedy (ed.) The Historiography of Islamic Egypt (C. 950-1800), Leiden, Boston (MA) and Köln: 149-65.

Habshī, 'A.M. (1994) Fibrist makhțūtāt ba'd al-maktabāt al-khāṣsa fī al-Yaman, London.

Hallaq, W.B. (1984) 'Was the Gate of ijtihād Closed?', International Journal of Middle East Studies 16: 3-41. 
(1986) 'On the Origins of the Controversy About the Existence of mujtahids and the Gate of ijtihād', Studia Islamica 63: 129-41.

(2001) Authority, Continuity, and Change in Islamic Law, Cambridge.

Halm, H. (1991) 'Die Ayyubiden', in U. Haarmann (ed.) Geschicbte der arabischen Welt, München: 200-16.

Hartmann, A. (2001) 'A Unique Manuscript in the Asian Museum, St. Petersburg: The Syrian Chronicle al-Ta'rīb al-Manșīrì by Ibn Nazîf al-Hamawī, from the 7th/13th Century', in U. Vermeulen and J. van Steenbergen (eds) Egypt and Syria in the Fatimid, Ayyubid and Mamluk Eras III, Leuven: 89-100.

Hathaway, J. (1996) 'Problems of Periodization in Ottoman History: The Fifteenth through the Eighteenth Centuries', The Turkish Studies Association Bulletin 20: 25-31.

Havemann, A. (1975) Ri'āsa und qadă'. Institutionen als Ausdruck wechselnder Kräfteverbältnisse in syrischen Städten vom 10. bis zum 12. Jabrbundert, Freiburg.

Heidemann, Stefan (2002) Die Renaissance der Städte in Nordsyrien und Nordmesopotamien: städtische Entwicklung und wirtschaftliche Bedingungen in ar-Raqqa and Harrān von der Zeit der beduinischen Vorherrschaft bis zu den Seldschuken, Leiden.

Heinzelmann, M. (1994) Gregor von Tours (538-594): Zebn Bücher Geschichte. Historiographie und Gesellschaftskonzept im 6. Jabrbundert, Darmstadt.

el-Hibri, T. (1999) Reinterpreting Islamic Historiography. Hārūn al-Rashīd and the Narrative of the 'Abbāsid Caliphate, Cambridge and New York.

Hillenbrand, C. (1988) 'Islamic Orthodoxy or Realpolitik? Al-Ghazali's Views on Government', Iran 26: 81-94.

— (1999) The Crusades. Islamic Perspectives, Edinburgh.

-(2001) '“Abominable Acts”: The Career of Zengi', in J. Phillips and M. Hoch (eds) The Second Crusade. Scope and Consequences, Manchester: 111-32.

Hirschler, K. (2005) 'Pre-Eighteenth-Century Traditions of Revivalism: Damascus in the Thirteenth Century', Bulletin of the School of Oriental and African Studies 68(2): 195-214.

Hitti, P.K., Faris, N.A. and 'Abd al-Malik, B. (1938) Descriptive Catalogue of the Garrett Collection of Arabic Manuscripts in the Princeton University Library, Princeton (NJ).

Hodgson, M.G.S. (1974) The Venture of Islam. Conscience and History in a World Civilization, 3 vols, Chicago (IL) and London.

Holt, P.M. (1980) 'The Virtuous Ruler in Thirteenth-Century Mamluk Royal Biographies', Nottingham Medieval Studies 24: 27-35.

_(1986) The Age of the Crusades. The Near East from the Eleventh Century to 1517, London and New York.

(1995) 'The Sultan as Ideal Ruler: Ayyubid and Mamluk Prototypes', in M. Kunt and C. Woodhead (eds) Süleyman the Magnificent and His Age. The Ottoman Empire in the Early Modern World, London and New York: 122-37.

Houdas, O. (tr.) (1895) Histoire du Sultan Djelal ed-Dīn Mankubirti. Prince Du Kharezm, Paris (tr. of al-Nasawì's Sìrat).

Hourani, A. (1983) Arabic Thought in the Liberal Age, 1798-1939, Cambridge (first edition 1962).

Humphreys, R.S. (1977) From Saladin to the Mongols. The Ayyubids of Damascus, 1193-1260, Albany (NY).

(1995) Islamic History. A Framework for Inquiry, London (revised edition).

'Īsā, A. (1942) Mu'jam al-ațibbà' min sanat $650 \mathrm{H}$. ilā yawminā hādhā, Cairo.

Jackson, S.A. (1996) Islamic Law and the State. The Constitutional Jurisprudence of Shihäb al-Din al-Qarāfīi, Leiden, New York and Köln. 
Jokisch, B. (1996) Islamisches Recht in Theorie und Praxis. Analyse einiger kaufrechtlicher Fatwas von Taqī'd-Dinn Abmad b. Taymiyya, Berlin.

Karatay, F.E. (1966) Topkapı Sarayı Müzesi Kütüphanesi. Arapça yazmalar kataloğu, vol. 3, Istanbul.

Kellner, H. (1995) 'Introduction: Describing Redescription', in F. Ankersmit and H. Kellner (eds) A New Philosophy of History, London: 1-18.

Kennedy, H. (1986) The Prophet and the Age of the Caliphates. The Islamic Near East from the Sixth to the Eleventh Century, London and New York.

Khalidi, T. (1994) Arabic Historical Thought in the Classical Period, Cambridge.

Khayat, H.M. (1971) 'The Šs̄'ite Rebellions in Aleppo in the 6th/12th A.D. Century', Rivista degli Studi Orientali 46: 167-95.

al-Khaymī, Ș. (1983-4) Fibrist makbțūtāt Dār al-Kutub al-Zābirīya - 'ulūm al-Qur'ān al-Karīm, 3 vols, Damascus.

Kinberg, L. (1985) 'The Legitimization of the madhābib Through Dreams', Arabica 32: 47-79.

- (1993) 'Literal Dreams and Prophetic Hadz̄t ts in Classical Islam - a Comparison of Two Ways of Legitimation', Der Islam 70: 279-300.

Kister, M.J. (1971) " Rajab is the month of God..." A Study in the Persistence of an Early Tradition', Israel Oriental Studies 1: 191-223.

Lambton, A.K.S. (1981) State and Government in Medieval Islam. An Introduction to the Study of Islamic Political Theory: the Jurists, Oxford.

Landau-Tasseron, E. (1989) 'The "Cyclical Reform”: a Study of the mujaddid Tradition', Studia Islamica 70: 79-117.

Laoust, H. (1948) Le traité de droit public d'Ibn Taimīya. Traduction annotée de la Siyāsa šarīya, Beirut.

(1955) 'Ibn Kațīr Historien', Arabica 2: 42-88.

Lapidus, I.M. (1975) 'Hierarchies and Networks: A Comparison of Chinese and Islamic Societies', in F. Wakeman and C. Grant (eds) Conflict and Control in Late Imperial China, Berkeley (CA), Los Angeles (CA) and London: 26-42.

(1984) Muslim Cities in the Later Middle Ages, Cambridge (second edition, first edition 1967).

Leder, S., al-Sawwās, Y.M. and al-Ṣāgharjī, M. (1996) Mújam al-samā'āt al-Dimashqūya. 550-750/1155-1349, Damascus.

Leiser, G. (1976) 'The Restoration of Sunnism in Egypt: Madrasas and Mudarrisūn 495-647/1101-1249', unpublished PhD Thesis, University of Pennsylvania.

Lewis, B. (1988) The Political Language of Islam, Chicago (IL).

Little, D.P. (1970) An Introduction to Mamluk Historiography. An Analysis of Arabic Annalistic and Biographical Sources for the Reign of al-Malik al-Nāșir Muhammad ibn Qalā'unn, Wiesbaden.

(1984) A Catalogue of the Islamic Documents from the al-Haram ash-Sharif in Jerusalem, Wiesbaden/Beirut.

(1998) 'Historiography of the Ayyūbid and the Mamlūk epochs', in C.F. Petry (ed.) The Cambridge History of Egypt, vol. 1: Islamic Egypt 640-1517, Cambridge: 412-44.

Lohlker, R. (1999) '“Unstatthafte Neuerungen” oder das Feld der religiösen Diskussion im Islam', Zeitschrift der Deutschen Morgenländischen Gesellschaft 149: 221-44.

Loimeier, R. (ed.) (2000) Die islamische Welt als Netzwerk. Möglichkeiten und Grenzen des Netzwerkansatzes im islamischen Kontext, Würzburg.

Loimeier, R. and Reichmuth, S. (1996) 'Zur Dynamik religiös-politischer Netzwerke in muslimischen Gesellschaften', Die Welt des Islams 36: 145-85.

Lowry, J.E. (1997) 'Time, Form and Self: The Autobiography of Abū Shāma', Edebiyât 7 (Special Issue - Arabic Autobiography): 313-25. 
MacKenzie, N.D. (1986) 'A Topographical Study of Cairo under the Ayyubids', unpublished $\mathrm{PhD}$ Thesis, University of Michigan.

Makdisi, G. (ed.) (1956-7) 'Autograph Diary of an Eleventh-Century Historian of Baghdad', Bulletin of the School of Oriental and African Studies 18 (1956): 9-31, 239-60 and 19 (1957): 13-48, 281-303, 426-43.

- (1981) The Rise of Colleges. Institutions of Learning in Islam and in the West, Edinburgh.

(1985) 'Freedom in Islamic Jurisprudence: ijtihād, taqlīd and Academic Freedom', in G. Makdisi, D. Sourdel and J. Sourdel-Thomine (eds) La Notion de liberté au Moyen Age, Paris: $79-88$.

Malti-Douglas, F. (1980) 'Dreams, the Blind, and the Semiotics of the Biographical Notice', Studia Islamica 51: 137-62.

Martel-Thoumian, B. (2005) 'La mort volontaire: le traitement du suicide et du suicidé dans les chroniques mameloukes tardives', Annales Islamologiques 38: 405-435.

Massé, H. (tr.) (1972) Conquête de la Syrie et de la Palestine par Saladin, Paris (tr. of 'Imād al-Dīn's al-Fath al-Qussiz).

Meyerhof, M. and Schacht, J. (1968) The Theologus Autodidacticus of Ibn al-Nafīs, Oxford.

Miura, T. (1997) 'Administrative Networks in the Mamlūk Period: Taxation, Legal Execution, and Bribery', in T. Sato (ed.) Islamic Urbanism in Human History. Political Power and Social Networks, London and New York: 39-76.

Morgan, D.O. (1982) 'Introduction', in D.O. Morgan (ed.) Medieval Historical Writing in the Christian and the Islamic Worlds, London: 1-4.

Morray, D. (1994) An Ayyubid Notable and His World. Ibn al-'Adīm and Aleppo as Portrayed in His Biographical Dictionary of People Associated with the City, Leiden, New York and Köln.

Mottahedeh, R. (1994) 'Some Islamic Views of the Pre-Islamic Past', Harvard Middle Eastern and Islamic Review 1: 17-26.

- (2001) Loyalty and Leadership in an Early Islamic Society, London and New York (second edition, first edition 1980).

al-Munajjid, Ș. (1955) 'Ijāzāt al-samā' fī al-makhțūțāt', Majallat ma'had al-makhtụtāt al-'arabìya 8: 232-51.

(1978) Mứjam al-mu'arrikhīn al-Dimashqūȳ̄n wa-athārubum al-makhțūta wa-al-mațbū'a, Beirut.

Mūsā, M. (1999) Mukbtașar Kitāb al-rawdatayn fī akbbār al-dawlatayn al-Nūrīya wa-al-Salāhīya lil-imām A $\bar{b}$ Shāma, Jadda.

Muștafāā, Sh. (1978) al-Ta'rīkh al-'Arabī wa-al-mu'arrikhūn. Dirāsa fī tațawwur 'ilm al-ta'rīkh wa-márifat rijälibi fí al-Islām, vol. 1, Beirut (vol. 2, Beirut 1979).

Nadwi, M.M. (1929) Catalogue of the Arabic and Persian Manuscripts in the Oriental Public Library at Bankipore, vol. 15, Patna.

Nagel, T. (1981) Staat und Glaubensgemeinschaft im Islam. Geschichte der politischen Ordnungsvorstellungen der Muslime, 2 vols, Zürich.

al-Nāṣir, Ṣ. (2002) 'S̄ìrat al-Malik al-Ẓāhir Baybars "al-Rawḍ al-zāhir fī sīrat al-Malik al-Z̄āhir" - aṣl am mukhtașar?', Ta'rīkh al-'Arab wa-al-'ālam 197: 77-98.

Nemoy, L. (1956) Arabic Manuscripts in the Yale University Library, New Haven (CT).

Northrup, L.S. (1998) From Slave to Sultan. The Career of al-Mansūr Qalāwūn and the Consolidation of Mamluk Rule in Egypt and Syria (678-689 AH/1279-1290 AD), Stuttgart.

Noth, A. (1998) 'Von der medinensischen "Umma" zu einer muslimischen Ökumene', in A. Noth and J. Paul (eds) Der islamische Orient - Grundzüge seiner Geschichte, Würzburg: 81-134.

Noth, A. and Conrad, L.I. (1994) The Early Arabic Historical Tradition. A Source-Critical Study, Princeton. 
Otter, M. (1996) Inventiones: Fiction and Referentiality in Twelfth-Century English Historical Writing, Chapel Hill (NC) and London.

Owen, R. (1975) "The Middle East in the Eighteenth Century - an "Islamic" Society in Decline? A Critique of Gibb and Bowen's Islamic Society and the West', Review of Middle Eastern Studies 1: 101-12.

Paret, R. (1977) Der Koran. Kommentar und Konkordanz, Stuttgart, Berlin and Köln.

Partner, N.F. (1977) Serious Entertainments: The Writing of History in Twelfth-Century England, Chicago (IL) and London.

Paul, J. (1996) Herrscher, Gemeinwesen, Vermittler: Ostiran und Transoxanien in vormongolischer Zeit, Stuttgart and Beirut.

Petruccioli, A. (ed.) (1995) Der islamische Garten. Architektur. Natur. Landschaft (tr. U. Stopfel), Stuttgart.

Pistor-Hatam, A. (1999) Nachrichtenblatt, Informationsbörse und Diskussionsforum: Ahtar-e Estānbūl (1876-1896) - Anstöße zur frühen persischen Moderne, Münster.

Pouzet, L. (1975) 'Maghrébiens à Damas au VIIe/XIIIe siècle', Bulletin d'Etudes Orientales 28: $167-99$.

_- (1985/86) 'Abū Shāma (599-665/1203-1268) et la société damascaine de son temps', Bulletin d'Etudes Orientales 37-38: 115-26.

- (1991) Damas au VIIe/XIIe siècle. Vie et structures religieuses dans une métropole islamique, Beirut (second edition, first edition 1988).

_- (1998) 'Remarques sur l'autobiographie dans le monde Arabo-Musulman au Moyen-âge', in U. Vermeulen and D. De Smet (eds) Philosophy and Arts in the Islamic World, Leuven: 97-106.

Poya, A. (1998) “Iğtihād” und Glaubensfreiheit: Darstellung einer islamischglaubensfreiheitlichen Idee anhand sunnitisch-rechtsmethodologischer Diskussionen', Der Islam 75: 226-58.

Quinn, S.A. (2000) Historical Writing during the Reign of Shab 'Abbas. Ideology, Imitation and Legitimacy in Safavid Chronicles, Salt Lake City.

Rabie, H. (1972) The Financial System of Egypt, AH 564-741/AD 1169-1341, London.

Rescher, N. (1964) The Development of Arabic Logic, Pittsburgh.

Reynolds, D.F. (ed.) (2001) Interpreting the Self. Autobiography in the Arabic Literary Tradition, Berkeley (CA), Los Angeles (CA) and London.

RHC OR $=$ Recueil des Historiens des Croisades - Historiens Orientaux, 5 vols, Paris 1872-1906.

Richards, D.S. (1982) 'Ibn al-Athīr and the Later Parts of the Kāmil: A Study of Aims and Methods', in D.O. Morgan (ed.) Medieval Historical Writing in the Christian and the Islamic Worlds, London: 76-108.

- (1993a) 'Imād al-Dīn al-Isfahānī. Administrator, Littérateur and Historian', in M. Schatzmiller (ed.) Crusaders and Muslims in Twelfth-Century Syria, Leiden, New York and Köln: $133-46$.

(1993b) 'The Crusade of Frederick II and the Hamāh Succession. Extracts from the Chronicle of Ibn Abī al-Damm', Bulletin d'Etudes Orientales 45: 183-200.

—-(tr.) (2001) The Rare and Excellent History of Saladin or al-Nawādir al-Sulțāniyya wa'l-Mahāsin al-Yüsufiyya by Bahä al-Dīn Ibn Shaddād, Aldershot.

Richter, G. (1933) Das Geschichtsbild der arabischen Historiker des Mittelalters, Tübingen.

Richter-Bernburg, L. (1998) Der syrische Blitz. Saladins Sekretär zwischen Selbstdarstellung und Geschichtsschreibung, Stuttgart.

Rikabi, J. (1949) La poésie profane sous les Ayyübides et ses principaux représentants, Paris.

Robinson, C.F. (2003) Islamic Historiography, Cambridge. 
Rosen, L. (1979) 'Social Identity and Points of Attachment: Approaches to Social Organization', in C. Geertz, H. Geertz and C. Rosen (eds) Meaning and Order in Moroccan Society. Three Essays in Cultural Analysis, Cambridge: 19-122.

Rosenthal, E.I.J. (1958) Political Thought in Medieval Islam. An Introductory Outline, Cambridge. Rosenthal, F. (1937) 'Die arabische Autobiographie', Studia Arabica 1: 1-40.

- (1946) 'On Suicide in Islam', Journal of the American Oriental Society 66: 239-59.

_-(tr.) (1967) The Muqaddima. An Introduction to History, 3 vols, Princeton (second edition, first edition 1958).

-(1968) A History of Muslim Historiography, Leiden (second edition, first edition 1952).

Rubiera y Mata, M.J. (1995) 'Der islamische Garten als Metapher des Paradieses', in A. Petruccioli (ed.) Der islamische Garten. Architektur. Natur. Landschaft (tr. U. Stopfel), Stuttgart: $13-24$.

Sartain, E.M. (1975) Jalāl al-Dīn Suȳutt̄in, vol. 1: Biography and Background, Cambridge.

Sato, T. (ed.) (1997) Islamic Urbanism in Human History. Political Power and Social Networks, London and New York.

Schacht, J. (1964) An Introduction to Islamic Law, Oxford.

Schimmel, A. (1998) Die Träume des Kalifen. Träume und ibre Deutung in der islamischen Kultur, München.

Schöller, M. (2004) The Living and the Dead in Islam. Studies in Arabic Epitaphs, vol.II: Epitaphs in Context, Wiesbaden.

Schöpflin, G. (1997) 'The Function of Myth and a Taxonomy of Myths', in G. Hosking and G. Schöpflin (eds) Myths and Nationhood, London: 19-35.

Şeşen, R., Altan, M.H. and Izgi, C. (1995) Kibris Islam Yazmalar Kataloğu, Istanbul.

Sewell, W.H. Jr. (1999) 'The Concept(s) of Culture', in V.E. Bonnell and L. Hunt (eds) Beyond the Cultural Turn: New Dimensions in the Study of Society and Culture, Los Angeles (CA) and London: 35-61.

Shumaysān̄̄, Ḥ. (1983) Madāris Dimashq fī al-'aṣr al-Ayyūbū, Beirut.

Sivan, E. (1985) 'Modern Arab Historiography of the Crusades', in E. Sivan, Interpretations of Islam. Past and Present, Princeton (NJ): 3-43.

de Slane, W. (1883-95) Bibliothèque Nationale. Catalogue des manuscrits arabes, Paris.

Smith, G., Law, V., Wilson, A., Bohr, A. and Allworth, E. (1998) Nation-Building in the Post-Soviet Borderlands: The Politics of National Identities, Cambridge.

Smith, J.M.H. (1997) 'Introduction: Regarding Medievalists: Contexts and Approaches', in M. Bentley (ed.) Companion to Historiography, London and New York: 105-16.

Spiegel, G.M. (1993) Romancing The Past. The Rise of Vernacular Prose Historiography in Thirteenth-Century France, Berkeley (CA), Los Angeles (CA) and Oxford.

(1997a) 'Towards a Theory of the Middle Ground', in G.M. Spiegel, The Past as Text. The Theory and Practice of Medieval Historiography, Baltimore (MD) and London: 44-56.

- (1997b) 'Introduction', in G.M. Spiegel, The Past as Text. The Theory and Practice of Medieval Historiography, Baltimore (MD) and London: XI-XXII.

- (1997c) 'Political Utility in Medieval Historiography. A Sketch', in G.M. Spiegel, The Past as Text. The Theory and Practice of Medieval Historiography, Baltimore (MD) and London: 83-98.

Springberg-Hinsen, M. (1989) Die Zeit vor dem Islam in arabischen Universalgeschichten des 9. bis 12. Jabrhunderts, Würzburg.

Steinberg, G. (2000) Religion und Staat in Saudi-Arabien. Eine Sozialgeschichte der wabhabitischen Gelehrten, 1912-1953, Diss. Phil. (FU Berlin).

Tabbaa, Y. (1997) Constructions of Power and Piety in Medieval Aleppo, University Park (PA). 
Thorau, P. (1987) Sultan Baibars I. von Ägypten. Ein Beitrag zur Geschichte des Vorderen Orients in 13. Jahrbundert, Wiesbaden.

Touati, H. (2000) 'La dédicace des livres dans l'Islam médiéval', Annales 55: 325-53.

Vajda, G. (1956) Les certificats de lecture et de transmission dans les manuscrits arabes de la Bibliothèque Nationale de Paris, Paris.

Waddy, C. (1934) 'An Introduction to the Chronicle Called Mufarrij al-kurūb fī akhbār banī Ayyūb', unpublished PhD Thesis, University of London.

_ (1972) 'An Historian Looks at the Middle East. Based on the Life of Ibn Wasil, Contemporary Historian of the Ayyubid Dynasty', Milla wa-Milla 11: 13-19.

Wagner, I. (1993) 'Geschichte als Text. Zur Tropologie Hayden Whites', in W. Küttler, J. Rüsen and E. Schulin (eds) Geschichtsdiskurs Band 1: Grundlagen und Methoden der Historiographiegeschichte, Frankfurt am Main: 212-32.

Waldman, M.R. (1981) “The Otherwise Unnoteworthy Year 711”: A Reply to Hayden White', Critical Inquiry 7: 784-92.

Watt, W.M. (1963) Muslim Intellectual. A Study of al-Ghazālī, Edinburgh.

- (1968) Islamic Political Thought. The Basic Concepts, Edinburgh.

(1974) 'The Closing of the Door of iğtihād', in J.M. Barral (ed.) Orientalia hispanica sive studia F.M. Pareja octogenario dicata, vol. 1: Arabica-Islamica, Leiden: 675-8.

Weintritt, O. (1992) Formen spätmittelalterlicher islamischer Geschichtsdarstellung. Untersuchungen zu al-Nuwairī al-Iskandarān̄̄s Kitāb al-ilmān und verwandten zeitgenössischen Texten, Beirut.

Weiss, B.G. (1978) 'Interpretation in Islamic Law: The Theory of ijtihād', The American Journal of Comparative Law 26: 199-212.

- (1992) The Search for God's Law. Islamic Jurisprudence in the Writings of Sayf al-Din al-Āmid $\bar{\imath}$, Salt Lake City.

Wescoat, J. (1986) 'The Islamic Garden: Issues for Landscape Research', Environmental Design (Journal of the Islamic Environmental Design Centre, Rome): 10-19.

White, H. (1973) Metabistory: The Historical Imagination in Nineteenth-Century Europe, Baltimore (MD) and London.

Wielandt, R. (1980) Das Bild der Europäer in der modernen arabischen Erzähl-und Theaterliteratur, Beirut.

Wolf, K.B. (1995) Making History: The Normans and Their Historians in Eleventh-Century Italy, Philadelphia (PA).

Wormhoudt, A. (1974) Diwan Ibn Nabih, William Penn College.

Wüstenfeld, F. (1882) Die Geschichtsschreiber der Araber und ibre Werke, Göttingen. 


\section{INDEX}

Note: Page numbers in italic indicate figures and numbers in square bracket indicate footnote numbers.

'Abbasid dynasty 8, 77, 90

'Abd al-'Azīz, Ibn Abī'Așrūn

(d. 643/1245-6) 22

'Abd al-Hamīd Bey Nāfi' (fl. 13th/19th century) 118

Abū al-Fidāā, al-Malik al-Ṣālih Ismāēîl

(Hama, d. 732/1332) 27, 60, 132[47], $145[130]$

Abū Shāma, 'Abd al-Rahmān (d. 665/1268) $1,2,7,28,42,58,62,112,122,123$; acquaintances $41-2$; cause for death 57 ; contribution to Islamic law 49-51; criticism by contemporaries 36-7; criticism of scholars and judges 28-31, 52-4, 113; dynastic biases 63, 67-9; family 33-4, 41; financial wealth 33 ; historical works 10-12; interest in auxiliary Arabic sciences 47; interest in rational sciences $47-8$; learning in religious sciences 44-6; links with Maghribian community 33, 34, 51; murder attempt 29, 37; murder of 37-8; political elite contacts 35-6; position in intellectual world 43 ; posts $31-3$; rational outlook 53-4; scholarly contacts 34-5; self perception 39-40, 56; suicide thoughts 38; teaching of his works 117 ; see also modes of emplotment; poetry; political thought; religious scholars agency $1,2,17,28,42,123$

Ahmad b. Hanbal (d. 241/855) 39

Aḥmad b. Rị̣wān (d. 665/1266) 35

'Alā al-Dīn Khwārazmshāh 72

al-'Alā' '̄, Khalīl b. Kaykaldī

(d. 761/1359) 118
'Alam al-Dīn Qayșar (d. 649/1251) 27, 60

Aleppo 8, 9, 12, 26, 27, 59, 73, 74, 84, 91, 94; biographical dictionaries 14

Alexander the Great see Iskandar/Dhū al-Qarnayn

'Alī, Caliph (d. 40/661) 79, 95

'Alī b. 'Abd al-Rahīm see Ibn al-Mughayzil

'ālims see scholars

'Alwān, Banū (Aleppo) 26

Ambros, A. 66, 67

al-Āmidī, 'Alī (d. 631/1233) 45, 47, 50, $59,60,61$

amīr jāndār 25

'Amr Mosque (or al-Jāmi' al-'Atīq) (Cairo) 22 al-Anșārī, Sharaf al-Dīn (d. 662/1264) 27-8, 124

Aqmar Mosque (Cairo) 24, 28; Ibn Wāșil's teaching post 22-3, 124

al-Asadī, Jāwalī, amir 91

'Asākir, Banū 34, 35

atābak 8, 23, 25, 96, 97

Auerbach, E. 4

authority 54-5

autobiography 39-40, 41-2

Aydughdī, Jamāl al-Dīn (d. 664/1265) 25, 26, 124, 126

Ayyubid dynasty 9-10, 13, 16, 24, 27, 63, $65,69,70-2,75,100,114$; end 76,84 ; inter-disputes $74,76,79$; regional versus central rule $7-8,100-1$

Bāb al-Naṣr, al-Ṣaghīr, Tūmā (Damascus) 143[74]

Baghdad 8, 14, 27, 30, 79, 90, 91, 99, 107, 111 
Bahā’ al-Dīn Zuhayr (d. 656/1258) 19-20, 23, 24, 124, 126

al-Bā'ith' 'alā inkār al-bida' wa-al-bawādith (Inducement to Reject Innovations and Misdeeds) (Abū Shāma) 47, 51-2

Balak b. Bahrām b. Artuq (d. 518/1124) 94, 95, 97, 101-2

Bāniyās, conquest of: anecdotes of pierced eye and lost ring 103-5, 106-7

al-Bārizī, Banū (Hama) 26

Barmakids 110

al-Barq al-Shāmī (The Syrian Thunderbolt) (al-Iṣfahānī) 67, 84-5, 87

Barqūq, Mamluk sultan (d. 801/1399) 116

Battle of the Mills (271/885) 84

Baybars, al-Malik al-Z̄āhir, Mamluk Sultan (d. 676/1277) 21, 25, 26, 67, 76, 79, 124, 126, 133[64]

al-Bayhaqī, Ahmad (d. 458/1066) 46

bid'a see innovation

Bilād al-Rūm 8, 113

biographical dictionaries $10,11,14,20$, 29, 34-6, 45, 46, 128[13]

biographies $12,68-9$

al-Birzālī, Muhammad (d. 636/1239) 146[156]

al-Birzālīi, al-Qāsim (d. 739/1339) 137[146]

al-Bușīī̄ī, Muhamammad (d. 695/1296) 46

Buyid dynasty 17, 129[4]

Cairo 9, 10, 13, 22, 27, 57, 79, 110, 116, 118, 119, 120; Miṣr 21, 22, 24, 26, 118 , 150[76]; al-Qāhira 20, 22

caliphate 100, 110, 111-12; Baghdad 111 companionship (subbalmulāzama) 19, 23, 24, 26, 28, 35; features 19-20

Conrad, L. 93

consensus $\left(i j m \bar{a}^{c}\right) 50$

Cook, M. 30

Crusades 7, 8, 9, 25, 33, 39, 77, 79, 88, 99, 100, 105, 106, 114, 121

culture 3-4

Dānishmendid-Saljuq conflicts 113-14

Dār al-Hadīth 30; al-Ashrafīya

(Damascus) 31, 44, 46, 49, 117;

al-Nūrīya (Damascus) 34, 35

Dầūd, Prophet (King David) 53, 81

Daw' al-qamar al-sārì ilā márifat al-bārī

(Light of the Nocturnal Moon to the

Knowledge of the Expert) (Abū Shāma) 48 decentralization 8,10

al-Dhahabī, Muhammad (d. 748/1348)

13,37

Dhayl (Supplement) (Abū Shāma) 10-11, 29, 36, 37, 77, 109; arrangement 87; autobiographical section 29, 31, 39, 40, 41; difference between the outlook of Rawdatayn and 12, 75, 87

dreams and visions 39-40, 42, 56, 79, 99, 100

Edessa 8, 93, 99

endowment (waqf) 16, 17, 25, 30-1, 32, 33,36

exclusion/inclusion 4, 5, chapter 5 passim

al-Fā'iz, Fatimid caliph (d. 555/1160) 70

al-Fā'izī, Sharaf al-Dīn (d. 655/1257) 25-6, 126

al-Fatḥ al-qussī fì al-fath al-qudsī (The Qussian Inspiration on the Conquest of Jerusalem) (al-Ișfahānī) 66

Fatimid dynasty 7, 9, 61, 70, 71, 72, 83, 90; literature against 11,72

Frederick I (d. 1190) 152[116]

Frederick II (d. 1250) 60

friendship (mawadda) 19, 20, 25, 61, 95

Frye, N. 4

Geertz, C. 3, 4

al-Ghazālīe, Muhammad (d. 505/1111) 48, $50,110,141[2]$

Gökböri, Muzaffar al-Dīn (Harrān, d. 630/1233) 88-9

governance see rule

al-Hadhabānī, Husām al-Dīn (d. 658/1260) $23,24,25,26,28,124,126$

al-Hādī, 'Abbasid caliph (d. 170/786) 107

Hadīqat al-akbbār (The Garden of News) (newspaper) 118, 119-20

badìth 38, 40, 46, 50, 51, 54-5, 59, 61, 87, 89, 141[7], 149[34]

hajj (pilgrimage) 20, 23, 25, 75

Hama 8, 10, 59-60, 102, 130[33]; Ibn Wāṣil 13, 15, 21, 22, 23, 24, 26-8, 60, $61,71,76,99,110,116$

al-Hamadhānī, Husayn (d. 643/1245) 145 [116]

al-Ḥanafī, 'U[?] wān b. 'Abd al-Nabī (fl. early 11 th/late 16 th century) 118

Hanafites 36, 118, 139[195] 
Hanbalites 30, 36, 39, 46, 58 al-Harīīī, 'Alī (d. 645/1247) 36-7

Hārūn al-Rashīd, 'Abbasid caliph (d. 193/809) 83, 84, 107

Hațīin, battle (583/1187) 9, 79

Havemann, A. 16

el-Hibri 2, 3, 109

bijra 85, 90

al-Hindī, Muhammad (d. 715/1315) 142 [43]

historical writing $1-3,4,65,103,122$; arrangement 4, 5-6; depersonalized textuality 40-2; European 3, 108, 147 [9], 151 [83]; fragmented arrangement style 86-9, 91-2, 93; linear arrangement style 88, 90-1, 92, 93; see also literary elements; social context; truth-value historicization 77-8, 84, 89; Golden age 78-81; post-Golden age period 83-4; pre-Islamic (ancient) history 81-3

Ibn 'Abd al-Salām, 'Abd al-'Azīz al-Sulamī (d. 660/1262) 31, 35, 37, 49, 51, $57,58,59$

Ibn Abi al-Damm, Burhān al-Dīn Ismāầ (fl. early 7 th/13th century) 27

Ibn Abī al-Damm, Shihāb al-Dīn Ibrāhīm (d. 642/1244) 21, 27, 124, $130[33]$

Ibn Abī Ṭayy, Yahyāa (d. 630/1233) 12, 66, $88,97,104$

Ibn al-'Adīm, 'Umar (d. 660/1262) 14, 104

Ibn al-Akfānī, Muhammad (d. 749/1348) 146[149]

Ibn al-'Arabī, Muhammad (d. 543/1148) 145 [123]

Ibn al-'Arabī, Muhammad Sa'd al-Dīn (d. 656/1258) 80

Ibn 'Asākir, 'Abd ar-Raḥmān (d. 620/1223) 30, 142[16]

Ibn 'Asākir, 'Alī (d. 571/1175) 11, 14

Ibn al-Athīr, 'Alī (d. 630/1233) 14, 92, 94, 96, 104

Ibn Bābishādh, Tāhir (d. 469/1077) 47

Ibn al-Badī', al-Fakhr (d. 657/1259) 141[11]

Ibn al-Bayțar, 'Abd Allāh (d. 646/1248) 26, 126, 146[155]

Ibn Daqīq al-'̄̄'d, Muhammad (d. 702/1302) 49, 56, 57

Ibn Farāh al-Ishbilī, Ahmad (d. 699/1300) $34,137[146]$
Ibn al-Furāt, Muḥammad (d. 807/1405) 36

Ibn al-Harastānī, 'Abd al-Karīm

(d. 662/1264) 44-5

(Ibn) Hassān (fl. 6th/12th century) 93-4, 95, 97, 98, 102

Ibn Jamā'a, Muhammad (d. 733/1333) 110, $111,112,114$

Ibn al-Jazarī, Muhammad (d. 833/1429) 53

Ibn Kathīr, Ismāììl (d. 774/1373) 37, 57, 135 [103]

Ibn al-Khabbāz, Muhammad (d. 631/1234) 146[157]

Ibn Khaldūn, 'Abd al-Rahmān (d. 808/1406) 2, 148[32]

Ibn Khallikān, Aḥmad (d. 681/1282) 12, 20, 24, 26, 32, 35, 124, 125, 126

Ibn Luqmān, Fakhr al-Dīn (d. 693/1293) 19-20, 23

Ibn Mațrūh, Jamāl al-Dīn (d. 649/1251) 20, 23-4, 25, 26, 124, 126

Ibn al-Mughayzil, 'Alī (d. 701/1302) $27-8,76,116$

Ibn Munīr, Ahmad (d. 548/1153) 104, 106-7

Ibn al-Muqaffa', 'Abd Allāh (d. 142/759) 110

Ibn Mūsak, amir (d. 644/1246-7) 136[132]

Ibn al-Mu'tazz, 'Abbasid caliph (d. 296/908) 84

Ibn al-Nafīs, 'Alī (d. 687/1288) 26, 61, 126

Ibn al-Nazîf, Muhammad (d. after 634/1236-7) 130[33]

Ibn al-Qalānisī, Hamza (d. 555/1160) 12

Ibn al-Qaysarānī (d. 707/1307) 151[82]

Ibn al-Ṣalāḥ, 'Uțmān (d. 643/1245) 35, 44, 51-2, 142[16]

Ibn San̄̄ al-Dawla, Ahmmad (d. 658/1260) 135[103], 138[178]

Ibn Șașrā, 'Abd al-Rahmmān (d. 664/1266) 35

Ibn Ṣaṣrā, Ahmad (d. 723/1323) 117

Ibn Shaddād, Muhammad (d. 632/1235) $12,14,74-5,88,92,124,125$

Ibn al-Shāghūrī, Mawdūd (d. 612/1215) 31

Ibn al-Shihna, Muhammad (d. 815/1412) 119

Ibn al-Ṣuqā̄īe Faḍl Allāh (d. 726/1326) 20,36

Ibn Taymīya, Aḥmad (d. 728/1328) 48, 51, 58, 60, 110-11, 111-12, 113, 114, 117 
Ibn Țuwayr, 'Abd al-Salām (d. 617/1220) 72

Ibn al-'Unayn, Muhammad (d. 630/1233) 92

Ibn Wāṣil, 'Imād al-Dīn (Ibn Wāṣil's father, d. 629/1232) 20-1, 22, 26-7, 30, 124

Ibn Wāṣil, Muhammad (d. 697/1298) 1, 2, 7, 10, 21, 29, 42, 62, 112, 122-3; criticism 61-2; dedication of works to ruling patrons 15; dynastic biases 63 , $70-2$; family $26-8$; interest in rational sciences 58-9, 61; patronage and networks 124-5, 126; patronage and networks during Ayyubid period 18, 21-2, 23-5; patronage and networks during Mamluk sultanate 25-6; pilgrimage (hajj) 23, 25; al-Rāzī influence on 60-1; teaching and juridical posts 20-1, 22-3, 24, 26, 28; works 10,12-13, 58; works on logic 60; see also religious scholars; modes of emplotment; poetry; social networks; Aqmar Mosque

Ibn Wāṣil, Sa'd Allāh (Ibn Wāṣil's cousin, d. 673/1275) 27,124

Ibn Wāṣil's brother 27, 124

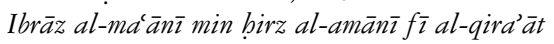
al-sab' (Abū Shāma) 45

al-Idrīsīi, Muhammad (d. 560/1165?) 131[5] ijäza 33, 34, 46, 116, 117, 132[47], 156[88] ijmā' see consensus

ijtibād/mujtabid 40, 46, 48-52, 53-4, 55, $56,57-8,62,111$; sources 49-51

innovation (bid'a) 34, 44, 47, 51-2, 111 institutions: existence or absence 16-17 iqrā' see Quranic reading

iqțā̄ 25,95

irony 92, 120; Ibn Wāṣil 79, 91, 92, 105

al-Ișfahānī, Abū al-Faraj

'Alī (d. 356/967) 15

al-Iṣfahān̄̄, 'Imād al-Dīn Muhammad (d. 597/1201) 12, 63, 67, 84-5, $87,88,92$

al-Ișfahān̄i, Muhammad b. Maḥmūd (d. 688/1289) 59

Iskandar/Dhū al-Qarnayn (Alexander the Great) 81

'Izz al-Dīn al-Afram (d. 695/1295) 25, 26, 27, 124, 126

'Izz al-Dīn Aybak see al-Malik al-Mu'izz

Jacbar, castle 101, 113; siege 93-8

jäbiliyaljābili rule 80, 105, 108
Jalāl al-Dīn Mingīrinī Khwārazmshāh

(d. 628/1231) 11, 72

al-Jamālī, Muhammad (d. 784/1382) 53

al-Jazā'irīi, 'Abd Allāh (d. 682/1283) 34, 46 al-Jazīra 7, 8, 9, 13, 25, 63, 76, 88,

$89,91,93$

Jazīrat Ibn 'Umar 99

Jerusalem 20, 21, 30, 33, 68, 71, 78, 79, $82,85,87,110,118,121$

jibād 99, 114

al-Jilyān̄̄, 'Abd al-Mun'im (d. 602/1205) 148 [28]

judges (qād $\bar{\imath} \mathrm{s}) \quad 29-30$

al-Jumal fí al-mantiq (The Sum of Logic)

(al-Khūnajī) 60

al-Jumayzī, 'Alī (d. 649/1252) 132[45]

jurisprudence $43,45,47,48-51,58,61$

al-Kāmil fì al-ta'rīkh (Ibn al-Athīr) 12, 14

Kanz al-muwaḅhidīn fì sīrat Șalāḅ al-Dīn

(Treasures of Those Professing the Oneness of

God: the Biography of Șalāh al-Dīn) (Ibn

Abī Țayy) 66

al-Karak 21, 59, 99-100

Kashf mā kāna 'alaybi ban̄̄' 'Ubayd min

al-kufr wa-al-kidhb wa-al-kìd (The

Disclosure of the Unbelief, Deceit and

Deception of the Ban̄' 'Ubayd)

(Abū Shāma) 11, 72

Kashf al-zunūn (Hājjī Khalīfa) 45, 46, 148 [22]

kātib al-sirr 116

khabar style 86

Khālid, Zayn al-Dīn (d. 663/1265) 35

Khalidi, T. 2-3, 16, 17

khațīblkhațībship 27, 30, 33, 45, 51, 110 , 135 [97, 98]

Khidr 100

al-Khūnajī, Muhammad (d. 646/1248) 26, $60,61,124,126$

al-Khūrī, Khalīi 118, 119, 120

al-Khusrūshāhī, Muhammad (d. 715/1315) 59, 61, 142[43]

khutba 71, 76, 87, 90, 133[51]

Khwārazm dynasty 11

Khwārazmian mercenaries 76

Kitāb al-aghānī (The Book of Songs)

(al-Ișfahānī, Abū al-Faraj) 15, 61

Kitāb al-basmala (Abū Shāma) 45-6

Kitāb al-ibar (Book of Lessons)

(Ibn Khaldūn) 2

Kitāb al-iḅkām fī ușūl al-aḅām (al-Āmidī) 47 
Kitāb al-rawdatayn fī akbbār al-dawlatayn al-Nürīya wa-al-Salābìya (The Book of the Two Gardens on the Reports of the Two Reigns) (Abū Shāma) 1, 5, 7, 10, 12, 63-4, 66, 68; abridgement 11-12, 117-18; comparison with al-Barq al-Shāmī 84-5; copies 116-18; difference between outlook of Dhayl and 12,75, 87; final passages of texts $72-5$; fragmented character of arrangement $86-8,91-2$; historical sources for 12 ; macro-arrangement 68-9; in nineteenth-century printing and press 118-20; purpose of 109; reception of $115,116-18,120-1$; supplement 76-7

Kitāb al-siyāsa al-shar'īya fì ișlāh al-rā'tì wa-al-ra'ina (Book of the Government in Line With the Divine Law: The Rectification of the Shepherd and the Flock) (Ibn Taymīya) 111

al-Kurrāsa al-jāmi' a li-masā'il nā $\hat{f}^{i} a$ (Sketchbook Assembling Useful Problems) (Abū Shāma) 48

al-Lakhmī, al-Ibrāhīmān (d. 790/1388) $156[88]$

Lapidus, I.M. 17, 18

learning and teaching $16-17$

literary elements $4,5,6,66,93-4,102$, 103,123

logic 43, 58-9, 60, 61; opposition to 44,54

Louis IX (d. 1270) 9

madhhab 25, 36, 39, 49

madrasas 22, 30, 44, 110; 'Adhrāwīya

(Damascus) 30; 'Ādilìya (Damascus) 32;

Jārūkhīya (Damascus) 30; Najībīya (Damascus) 137[147]; Nāṣirīya/Ṣalāhīya (Jerusalem) 20, 30, 124, 152[123]; Nūrīya (Damascus) 30; rise and development 16-17; Ruknīya (Damascus) 31; Zāwiya (Cairo) 21, 24, 124

Maghribian exile community (Damascus) 33, 34, 45, 46

Makdisi, G. 19, 20

al-Malik al-'Ādil b. Ayyūb (Egypt/Syria, d. 615/1218) 7, 9, 30, 32, 70, 74, 89, 90 al-Malik al-Afḍal 'Alī (Damascus, d. 622/1225) $14,70,74,83,84$ Mālik b. Anas (d. 179/795) 83
al-Malik al-Ashraf Mūsā (Damascus, d. 635/1237) 32, 44, 74, 99-100, 110, 141[12], 152[121], 154[49]

al-Malik al-'Azīz Muhammad (Aleppo, d. 634/1236) 76

al-Malik al-'Azīz 'Uțmān (Egypt, r. 589/1193-595/1198) 70, 83 al-Malik al-Kāmil Muhammad (Egypt, d. 635/1238) 7, 9, 60, 74, 149[53] al-Malik al-Manșūr b. Aybak, Mamluk sultan (d. 657/1259) 20, 124,126

al-Malik al-Manșūr I Muhammad (Hama, d. 617/1221) $13,59,60,124$

al-Malik al-Manșūr II Muhammad (Hama, d. 683/1284) 15, 21, 26, 27, 60, 61, 124

al-Malik al-Mu'azzam 'Īsā (Damascus, d. 624/1227) 11, 20, 74, 124

al-Malik al-Mughīth 'Umar (Karak, d. 662/1264) 145[129]

al-Malik al-Mu'izz Aybak, Mamluk sultan (d. 655/1257) 9, 25, 71, 84

al-Malik al-Muzaffar Mahmūd II (Hama, d. 642/1244) $23,27,124$

al-Malik al-Muzaffar Mahmūd III (Hama, d. 698/1299) 82, 157[10]

al-Malik al-Nāṣir Dāūùd (Damascus/Karak, d. 656/1258) 21, 27, 59, 99-100, 124

al-Malik al-Nāṣir Yūsuf (Aleppo, d. 658/1260) 84

al-Malik al-Șālih Ayyūb (Damascus/Egypt, d. 647/1249) 7-8, 9, 12, 15, 20, 21, 22, 35-6, 70, 100, 124, 126, 152[121]; entourage 23-4

al-Malik al-Ṣālih Ismā̄îl (Damascus, d. 648/1251) 23

al-Mālikīi, Ismā̄î̀l b. Ahmad (d. 680/1281) 35, 137[146]

Mālikites 34, 41, 51, 137[146], $145[123]$

Mamluks 9-10, 16-17, 24-6, 27, 70-1, $76,102,111,132[24], 133[64,65]$

Manbij 94, 95, 97, 101

Manfred, ruler of Sicily (d. 1266) $15,58-9$

al-Manșūr al-Rashīd, 'Abbasid caliph (d. 530/1136) 98, 154[49]

al-Marāghī, al-Badr (d. 660/1262) 141[11] mawadda see friendship al-Māwardī, 'Alī (d. 450/1058) 110 meaning 3-4, 6 metaphors: use in titles $67-8,90$ 
al-Mișrī, Yūsuf (d. 685/1286) 34

modes of emplotment 4, 64, 108, 114, 123; Abū Shāma's 64-5, 67, 72, 120; analysis 65-6, 72-7, 77-85, 86-103; Ibn Wāṣil's 65, 69, 120

Mongols 9, 11, 25, 33, 36, 69, 72, 75, 82, $85,111,113,128$ [9], 134[93], 151 [81] motifs 93; arrow motif 93-4, 95, 97, 101-2, 103-4, 105, 106

Mottahedeh, R. 17

Mu'āzz b. Jabal (d. 18/639) 54

Mufarrij al-kurūb fī akbbār ban̄̄ Ayyūb (The Dissipater of Anxieties on the Reports of the Ayyubids) (Ibn Wāṣil) 1, 5, 10, 13, 15, 66; as commentary on contemporary society 58, 63-4; copies 115; extension 76 ; final passages of texts $72,73,75-6$; historical sources 13; purpose of 28 , 109-10, 120; reception 115-16, 120; supplement 27, 76, 116; title 69-71

Mufradāt al-qurrà' (Expressions of the Quran Readers) (Abū Shāma) 46

al-Mughayzil, Banū 27, 28

Muhammad, Diyā' al-Dīn (d. 647/1250) 36

Muhammad, Jamāl al-Dīn (d. 707/1307) 20

Muhammad, Najm al-Dīn (d. 695/1296) 20

Muhammad, Prophet 39, 40, 44, 54, 69, $77,78,79,84,100$; acts of 50-1; ascension 46, 48; companions 54, 79; veneration of 46

Muhammad b. Qalāwūn, Mamluk sultan (d. 741/1341) 118

al-Mubaqqaq min' 'ilm al-uṣul fìmā yata'allaqu bi-af'āl al-Rasūl (What Can Be Ascertained of Theoretical Jurisprudence with Regard to the Acts of the Prophet) (Abū Shāma) 47, 50

Muhī al-Dīn Muhammad Ibn Sa'̄̄od (al-Jazīra, d. 651/1253-4) 138[162] mubtasib 16, 30, 117

mujaddid see tajdīd

mujtabid see ijtibād

Mukbtașar al-arba'īn fī usūl al-dīn (The Summary of the Forty [Questions] on the Bases of Religion) (al-Rāzī) 60-1

Mukbtasar al-mu'ammal lil-radd ilā al-amr al-awwal (Summary of What Can Be Hoped for to Restore the Original State) (Abū Shāma) 47, 49-50

Muqaddima fì al-nabw (Introduction to Grammar) (Ibn Bābishādh) 47 muqallids see taqlīd
al-Murshid al-wajīz ilà'ulūm tata'allaqu bi-al-kitāb al-'azīz (Concise Guide to Sciences Connected to the Venerable Book) (Abū Shāma) 45, 53

al-Mutanabbī, Ahmad (d. 354/965) 119

Muzaffar al-Dīn Ibrāhīm, amir (d. 654/1256) 35-6

al-Nabulūsī, 'Abd al-Ghanī (d. 1143/1731) 40

$n \bar{a}$ 'ib al-saltana 23

al-Nasawī, Muhammad (d. 647/1249-50) 11

al-Nawādir al-sulțān̄yya wa-al-mabāsin al-Yüsufīya (The Sultanic Anecdotes and the Yusufit Merits) (Ibn Shaddād) 66, 85

al-Nawawī, Yahyā (d. 676/1277) 44-5, 49, 53

nāzir al-jaysh 23

nāzir al-khizānalnāzir bayt al-māl 23

Nazm al-durar fì al-hawādith wa-al-siyar (The String of Pearls Concerning the Episodes and Biographies) (Ibn Wāṣil) 15

networks see social networks

newspapers and periodicals: serialization 119,120

Noth, A. 93

Nukbbat al-fikar fì al-mantiq (The Pick of Reflection on Logic) (Ibn Wāṣil) 60

Nūr al-Dīn, al-Malik al-'Ādil (d. 569/1174) 5, 7, 10, 13, 65, 69, 77, 103, 119, 121; anecdote of lost ring 103, 104-5, 106-8; asceticism 83; campaign against Qilij Arslān 113-14; chronicles 63; ideal rule $67,68,72,73-4,100-1$; image of just ruler 101-2, 106; links between Golden age and 77, 78, 79-80, 90; links between other periods and 81-4; military exploits 8-9, 107; parallels between al-Rashīd and 107-8; relations with Nusrat al-Dīn 104,105

Nușrat al-Dīn b. Zankī 96, 105, 108; loss of an eye 103, 104, 106

al-Nuwayrī, Muhammad (d. after 776/1374) 128[13]

Nuzhat al-muqlatayn fī akbbār al-dawlatayn (The Two Eyes' Entertainment on the Reports of the Two Rules) (Ibn Tuwayr) 72 
Nuzhat al-muqlatayn fī akbbār al-dawlatayn al-'Alā'sya wa-al-Jalātìya (The Two Eyes' Entertainment on the Reports of the Two Rules of 'Alā'al-Dīn [d. 617/1220] and Jalāl al-Dīn) (Abū Shāma) 11, 72

obituary notices $12,44,74,75,99,106$

Pahlawān Muhammad b. Eldigüz (d. 582/1186) 91

panegyrics 42, 71, 79, 88-9, 106; description of the Mufarrij as $15-16,28$

patronage $18,21-2,59-60$

Paul, J. 17

periodicals see newspapers and periodicals pharaohs 81,82

poetry 3, 5, 6, 79, 119; Abū Shāma and $12,48,88,89,92,98,104,105$, 106-7, 108; Ibn Wāșil and 24, 27, 61, 88, 92, 93, 100, 102, 103, 104, 106; in praise of Prophet Muhammad 46

political thought 109-10, 119; Ibn Jamāa and 110-11; Ibn Taymiya and 111-12; Ibn Wāṣil/Abū Shāma and 112-13 prayer of supplication $51,54-5$ printing press $118-20$

process (mode of emplotment) 64, 65, 69-70, 72, 73, 76, 77, 81, 83, 84, 86, $92,93,101,103,108,114,120,123$

al-Qāḍī al-Fāḍil (d. 596/1200) 24, 70, 73, 88,90

al-Qalānisī, Banū 12

Qașidat al-burda (Poem on the Prophet's Outer Garment) (al-Bușīīī) 46

al-Qazwīnī, 'Alī (d. 675/1276) 60

Qilij Arslān II, Saljuq sultan (Bilād al-Rūm) 113, 114

qiyās see reasoning by analogy

Quran 38, 39, 68, 79, 81, 90; as source of law 47, 48-50, 52, 53, 57; specific verses cited: (9:35) 153[16], (12:99) 152[113], (21:78) 144[95], (39:73) 149[36], (55:46) 149[35], (58:22) 153[15], (93:11) 39

Quranic exegesis (tafsīr) 43, 46, 141[12]

Quranic reading (iqra $\left.\vec{a}^{\prime}\right) 43,45-6,53,57$, 136[130]

al-Qurashīya, Karīma (d. 641/1243) $137[145]$
al-Qurțubī, 'Alī (d. 671/1273) 35, 137[146]

Qūṣ (Egypt) 22, 25

rational sciences $43,44,47-8,53-4$, 58-60, 61, 62, 83

Rawd al-manāzir fí 'ilm al-awa' il wa-al-awäkhir (The Gardens of Sights: Knowledge of the Origins and the Last Things) (Ibn al-Shihna) 119 al-Rawd al-zāhir fī sìrat al-Malik al-Zāhir (The Radiant Garden of al-Malik al-Z̄āhir's Biography) (Ibn 'Abd al-Zāhir) 67,76

ra'y (personal judgement) 37, 57

al-Rāzī, Fakhr al-Dīn (d. 606/1209) 60-1, 156[101]

reasoning by analogy (qiyās) 50

reformers: Christian Syrian-Lebanese 119-20

religious scholars 26, 38, 43, 59; Abū Shāma and 28-34, 36, 37, 40, 44, 46, $52-3,56,75,77,113$; criticism of 28-31, 36, 37, 52-4, 113; in historical writing 10, 11, 12, 13, 14, 15, 99; Ibn Wāṣil and 21, 23, 24, 26, 77-8

religious sciences $43,44-8,54,58,59$, 60-1, 62

rhymed prose $\left(s a j^{\circ}\right)$ 63, 66

rhymed titles 66-7, 72

al-Risāla al-Anbrürīya (The Imperial Treatise) (Ibn Wāșil) 15

Rosenthal, F. 2, 16, 122

rule: ideal rule $10,77-8,83-4,106,107$, 108, 109-10, 114, 120; jābili versus ideal rule 105, 108; metaphor for ideal rule 67-8; regional versus central 8-10, 93, 99-101, 110-12

rulers 98, 99-101; legitimacy 110 , 111-12, 113, 114; morality 101, 102-3

Rūzbehān Baqlī (d. 606/1209) 139[198]

al-Sakhāwī, 'Alam al-Dīn (d. 643/1245) 28, $31,33,35,36,38,45,46,142[16]$

Șalāh al-Dīn 7, 9, 13, 14, 65, 69, 73, 74, 77, 83, 114, 119; chronicles 63; comparison to Prophet Yūsuf (Joseph) 66, 81, 89-90; conquest of Jerusalem $78-9,85,121$; ideal rule $67-8,72,75$, 85, 100-1, 109-10, 112; links between Golden age and 78-80, 90; siege of Mosul 88-92 
salāt al-Raghä'ib see prayer of supplication The Sälibian History (al-Ta'rīkh al-Sālibū)

(Ibn Wāṣil) 12-13, 15, 116

Saljuq dynasty $8,10,110,113,131[18]$

al-Sāmirī, Yūsuf (d. after 680/1281) $146[143]$

al-Sanūs̄i, Muhammad (d. 1276/1859) 57

al-Saqațī, Ishāq (d. 665/1267) 35

Sasanid dynasty 81,82

satire see irony

Sayf al-Dīn Ghāzī b. Zankī

(d. 544/1149) 8,96

scholars 7, 36-7, 112; social position and scholarship 16-19, 28

sciences: classification 43

Sewell, W.H. Jr. 4

al-Sha'bī, 'Āmir (d. 103/721) 145[120]

al-Shāfi ${ }^{\top}$, Muhammad (d. 204/820) 50

al-Shāfi'ī, Yūsuf (d. 685/1286) 117

Shāficites 26, 34, 36, 38, 42, 44-5, 50, 57-8, 110

al-Shāghūrī, Muhammad (d. 676/1277) 35

Shāh Walī Allāh (d. 1180/1766) 58

Shajar al-Durr Umm Khalīl (Egypt, d. 655/1257) 9

Shams al-Dīn Mahmūd (d. 656/1258) $136[124]$

al-Shaqrātīis̄i, Muhammad

(d. 466/1074) 46

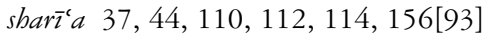

al-Shāțib̄̄, al-Qāsim (d. 590/1194) 45, 57

Shāwar, Fatimid vizier (d. 564/1169) $152[116]$

al-Shawkān̄̄, Muhammad (d. 1250/1834) 57

shaykh al-shuyükh 27, 135[98]

al-Shīrāzī, Ibrāhīm (d. 476/1083) 50

Shīrkūh, Asad al-Dīn (d. 564/1169) 79, 105

Sibt b. al-Jawzī (d. 654/1256) 14, 104

Șiffīn, battle (37/657) 155[58]

al-Șiqillī, Ahmad (d. 664/1266) 35

Sìrat al-Sultān Jalāl al-Dīn Mingīrin̄i (The

Biography of Sultan Jalāl al-Dīn Mingīinin (al-Nasawī) 11

Sitt al-'Arab (Abū Shāma's wife) 41

al-Siwāk wa-mā ashbaha dhäk (Cleansing the

Teeth and What Resembles it)

(Abū Shāma) 48

siyāsa history 14

social context $1,3,6,14,15-17$,

$18,20,58,62,65,112$ social networks 18-19, 64; Ibn Wāșil's 21, 23-8, 101, 112, 124, 126; quality of relationships 19

society: Middle Eastern 16

Spiegel, G.M. 3

stasis (mode of emplotment) 64-5, 67-8, 72, 73, 74, 75, 77, 84, 92, 93, 101, 103, $108,114,120,123$

student-teacher relationships 17, 19-20, 28,35

al-Subkī, 'Abd al-Wahhāb (d. 771/1370) 30,46

subbalmulāzama see companionship

suicide 38,42

Sulaymān (King Solomon), Prophet 53-4, $56,81,106$

sultanate 111

Sunna $48,52,53$; as source of law 50-2, 57

al-Suyūṭī, 'Abd ar-Rahmān (d. 911/1505) $56,58,112$

al-Suyūṭī, 'Alī (fl. 13th/19th century) 118

The Syrian Press (al-matba'a al-Sürīya) 118, 119

al-Tabarī, Muhammad (d. 310/923) 2, 86 tafsìr see Quranic exegesis

Tafsizr ayat al-asra ' (Interpretation of the Ascension Verse) (Abū Shāma) 46

Tabrīr al-abkām fì tadbīr abl al-islām (Rules for the Governance of the People of Islam) (Ibn Jamāaca) 111

tajdīd/mujaddid 40, 55-6

Tajrìd [Mukbtasar] al-aghān̄i (Ibn Wāṣil) 61

Talā’i $i^{i}$ b. Ruzzīk, Fatimid vizier (d. 556/1161) 70

Taqī al-Dīn 'Īsā (d. 602/1206) 38

taqlīd/muqallid 48, 52-5, 56

al-Ta'rīkh al-kabìr (The Grand History) (Ibn Wāșil) 13

Ta'rīkh madīnat Dimashq (The History of Damascus) (Ibn 'Asākir) 14; abridgement 11

Tàrīkh al-rusul wa-al-mulük (al-Ṭabarī) 2 tedhkirici 118

al-Tha'ālib̄̄, 'Abd al-Malik (d. 429/1038) 152[111]

theology (kalām) 47-8, 53, 60-1

titles and guiding phrases 69-70, 72, 76, 84-5, 90, 107, 118; choice of guiding phrases 67 ; rhymed titles 66 
topoi 93

truth-value 123

Tūrānshāh, al-Malik al-Mu'azzam (d. 648/1250) 9, 12, 15, 23, 25-6, 124,126 ; murder of 25

Turba Umm al- Ṣālih 136[130] al-Turtūishī, Muhammad

(d. 520/1126) 34

'ulūm al-awā'il see rational sciences

'Umar II b. 'Abd al-'Azīz, Umayyad caliph (d. 101/720) 83, 84

'Umar b. al-Khațāa, Caliph (d. 23/644) 39, 78, 83, 100, 121

Umayyad Mosque (Damascus) 27, 44, 51,117

Unur, Mu'īn al-Dīn (Bāniyās) 106 al-'Uqaylī, Mālik (Qal'at Ja'bar) 93-95

ustādh al-dār (major-domo) 23

ușul al-fiqh see jurisprudence

'Uthmān, Caliph (d. 35/656) 79, 107

Uthmān b. Sa'd (d. 639/1241) 22

'Uȳ̄n al-Rawdatayn (The Essence of the Two Gardens) (Abū Shāma) 11-12, 117-18
Wādī al-Nīl press 120

al-Wādih al-jalī fì al-radd' alā al-Hanbalī (The Elucidated and Clear Refutation of the Hanbalite) (Abū Shāma) 46

Wahb b. Munabbih (d. 114/732) 144[100] wālīiwālì al-balad 25, 38

waqf see endowment al-Wāṣițī, 'Alī (d. 665/1266) 35

White, H. 4, 64

wine consumption 102-3

Woe, then I am not a European (Way, idhan lastu bi-Ifranjī) (al-Khūrī) 120

al-Yūnīnī, Muhammad (d. 658/1260) 46

al-Yūnīnī, Mūsā (d. 726/1326) 36

al-Zamakhsharī, Mahmūd (d. 538/1144) 47

Zangid dynasty 7, 8-9, 12, 13, 71

Zankī, 'Imād al-Dīn (d. 541/1146) 8, 101, 102, 105, 148[32]; criticism 98, 102-3; disloyalty 98-9; fight against Crusaders 99; siege of castle Ja'bar 93, 94-7

al-Zaynī, Shams al-Dīn Aḥmad b. Aḥmad b. Muhammad (fl. 8th/14th century) 116 
eBooks - at www.eBookstore.tandf.co.uk

\section{A library at your fingertips!}

eBooks are electronic versions of printed books. You can store them on your PC/laptop or browse them online.

They have advantages for anyone needing rapid access to a wide variety of published, copyright information.

eBooks can help your research by enabling you to bookmark chapters, annotate text and use instant searches to find specific words or phrases. Several eBook files would fit on even a small laptop or PDA.

NEW: Save money by eSubscribing: cheap, online access to any eBook for as long as you need it.

\section{Annual subscription packages}

We now offer special low-cost bulk subscriptions to packages of eBooks in certain subject areas. These are available to libraries or to individuals.

For more information please contact webmaster.ebooks@tandf.co.uk

We're continually developing the eBook concept, so keep up to date by visiting the website.

www.eBookstore.tandf.co.uk 